ANA LÚCIA MENEZES VIEIRA

O SIGILO DA FONTE DE INFORMAÇÃO JORNALÍSTICA COMO LIMITE $\square$ PROVA NO PROCESSO PENAL

DOUTORADO

ORIENTADOR: PROFESSOR DOUTOR ANTONIO MAGALHÃES GOMES FILHO

FACULDADE DE DIREITO DA UNIVERSIDADE DE SÃO PAULO SÃO PAULO 
ANA LÚCIA MENEZES VIEIRA

\title{
O SIGILO DA FONTE DE INFORMAÇÃO JORNALÍSTICA COMO LIMITE $\square$ PROVA NO PROCESSO PENAL
}

\author{
Tese apresentada à Faculdade de Direito da \\ Universidade de São Paulo, como requisito \\ parcial para obtenção do título de Doutor em \\ direito. Área de concentração: Direito \\ Processual.
}

Orientador: Professor Titular Doutor Antonio Magalhães Gomes Filho 
BANCA EXAMINADORA

1.

2.

3.

4.

5. 
Alguém me indicou o caminho e por anos, orientoume como percorrê-lo; com paciência, dedicação e apoio permitiu que eu aqui chegasse. Eu tenho alguém a quem posso chamar de "Mestre": Professor Doutor Antonio Magalhães Gomes Filho, a minha eterna gratidão!

Aos Professores Doutores Antonio Scarance Fernandes e Gustavo Henrique Righ Ivahy Badaró, pelas orientações e conselhos na realização deste trabalho.

Ao Professor Doutor Maurício Zanoide de Moraes, pelo apoio e ensinamento que se seguiram ao desafio da idéia defendida. Muito obrigada!

Ao Doutor Manuel Alceu Affonso Ferreira, pelo incentivo que me impulsionou a continuar a pesquisa na área do Direito da Comunicação.

Ao Doutor Pedro Brenna Filho, pelos constantes debates que me ajudaram a pensar o tema.

A todos aqueles que, de alguma forma, auxiliaram-me na realização desta pesquisa. 
DEDICATÓRIAS

À minha mãe Maria Aparecida (in memoriam), exemplo de vida.

Ao meu pai, Alfredo Augusto, constante incentivo.

À minha família, convívio alegre que fortalece. 
"A meio caminho entre a fé e a crítica está a estalagem da razão. A razão é a fé no que se pode compreender sem fé; mas é uma fé ainda, porque compreender envolve pressupor que há qualquer coisa compreensivel."

Fernando Pessoa 


\section{O SIGILO DA FONTE NO CONTEXTO DA LIBERDADE DE INFORMAÇÃO}

1.1 A dimensão democrática das "liberdades da comunicação" .007

1.2 Informação: liberdade ou direito?. 011

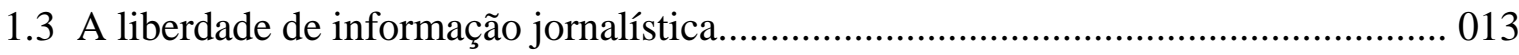

1.4 As vertentes da liberdade de informação: direito de informar e ser informado..........019

$1.5 \mathrm{O}$ sigilo da fonte como instrumento da liberdade de informação...............................021

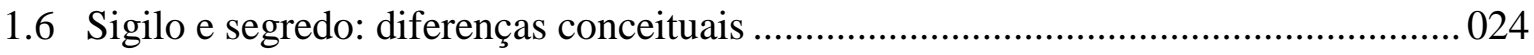

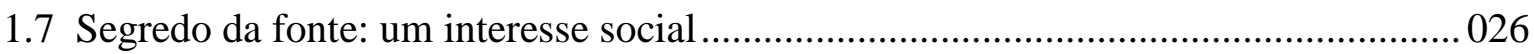

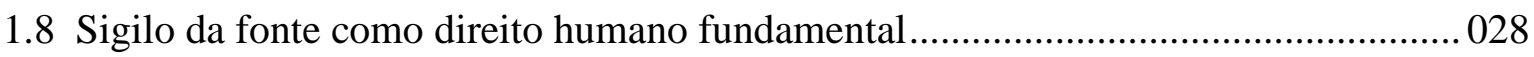

1.9 A garantia do sigilo da fonte de informação jornalística na Constituição brasileira... 032

1.9.1 Evolução constitucional da liberdade de expressão e informação....................... 033

1.9.2 A positivação do sigilo na Constituição de 1988................................................ 039

1.9.3 Status jurídico-normativo do sigilo: direito e garantia ....................................... 040

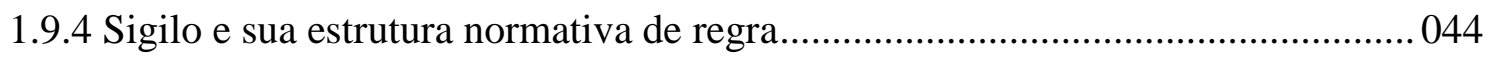

\section{SEGREDO PROFISSIONAL DO JORNALISTA NO DIREITO CONSTITUCIONAL ESTRANGEIRO: FONTES NORMATIVAS E JURISPRUDÊNCIA.}

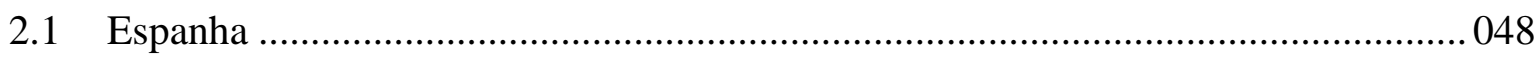

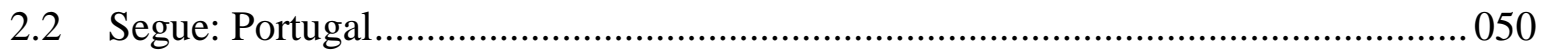

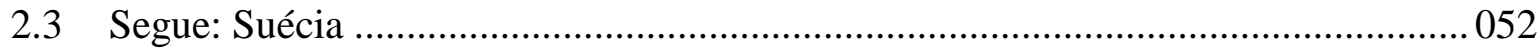

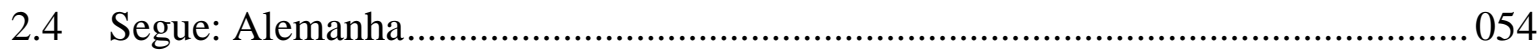

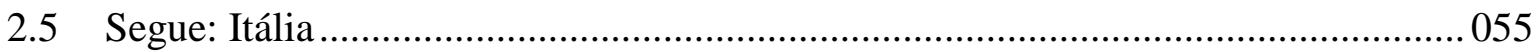

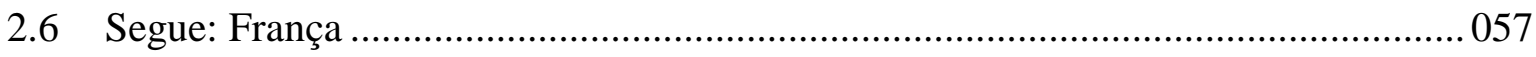




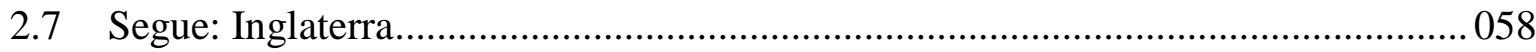

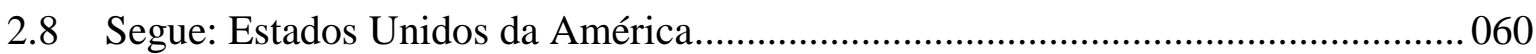

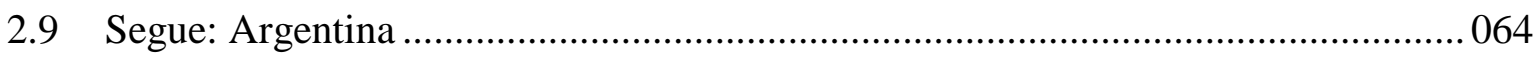

2.10 Consagração jurisprudencial do sigilo da fonte no

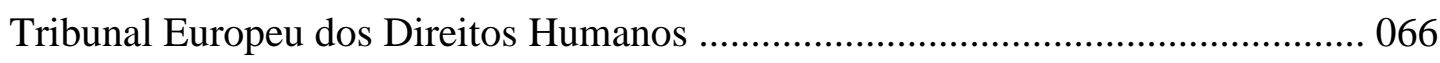

2.11 O sigilo da fonte no Sistema Interamericano de Direitos Humanos.............................071

2.11.1 O segredo jornalístico no âmbito de proteção da liberdade de imprensa

2.11.2 A interpretação do art. 13 da Convenção Americana de Direitos Humanos pelo Tribunal da Costa Rica. 076

III. O JORNALISMO INVESTIGATIVO, BUSCA DA VERDADE E PROVA PENAL .080

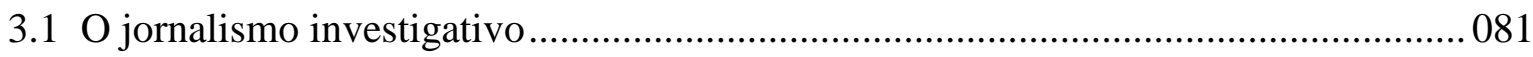

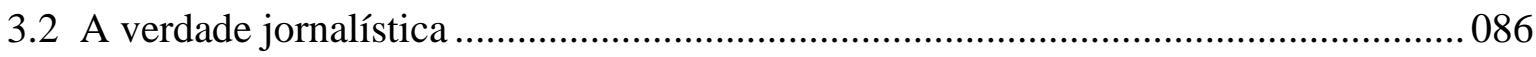

3.3 Busca da verdade: acesso às fontes de informação........................................................090

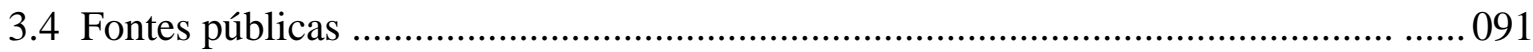

3.4.1 Segredo de Estado como limite - noções gerais .................................................094

3.4.2 Segredo de Estado: excepcionalidade. Casos

ilustrativos referentes a investigações criminais................................................101

3.5 O processo penal como fonte de informação jornalística ............................................102

3.6 A investigação criminal e o segredo de justiça como

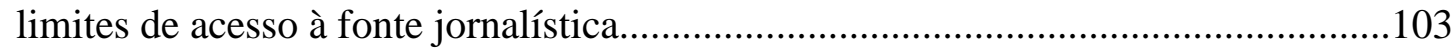

3.7 A responsabilidade do jornalista pela divulgação de informações sob segredo de justiça

3.8 O investigador midiático e o processo penal: procedimento de busca das informações jornalísticas. Fontes ocultas. "Câmeras escondidas". Interceptações telefônicas.

3.9 Os meios de busca da verdade midiática e o inquérito policial .120

\section{A PROVA, A BUSCA DA VERDADE NO PROCESSO PENAL E O SEGREDO PROFISSIONAL COMO LIMITE}

4.1 Garantia e eficiência processuais: a necessária relação com a prova 
4.2 Qual a "verdade" buscada no processo penal? ........................................................ 131

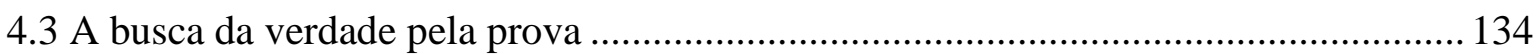

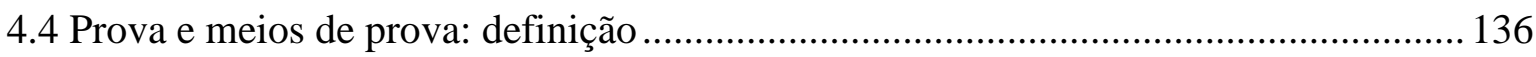

4.5 Procedimento e proibição de prova: limites à verdade .............................................. 138

4.6 Segredos profissionais e religiosos como limites à prova: fundamentos...................... 141

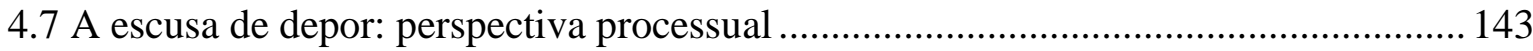

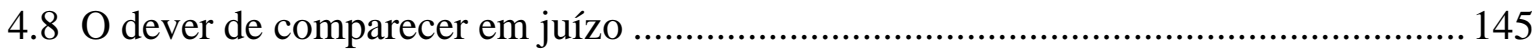

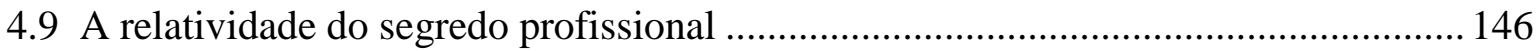

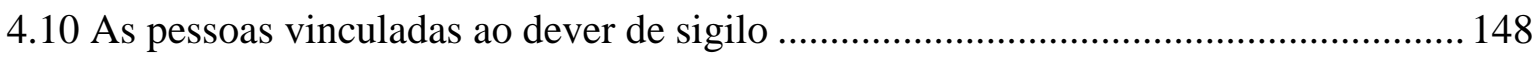

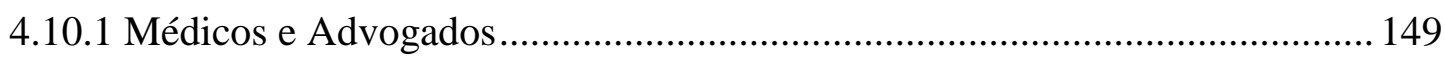

4.10.2 Ministros de cultos religiosos ................................................................. 152

\section{A RELAÇÃO DO SIGILO DA FONTE DE INFORMAÇÃO} JORNALÍSTICA COM A PROVA PENAL

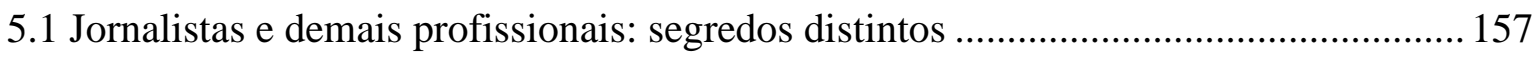

5.2 Quem são os destinatários do sigilo da fonte? ......................................................... 159

$5.3 \mathrm{O}$ jornalista como testemunha no processo penal ....................................................... 161

5.4 O segredo do jornalista é segredo profissional para fins do artigo 207 do Código de Processo Penal?................................................ 162

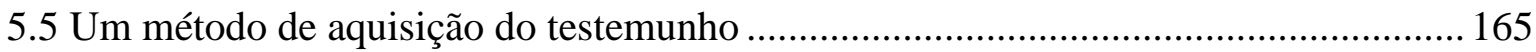

5.6 A necessidade do sigilo para o exercício profissional ............................................... 167

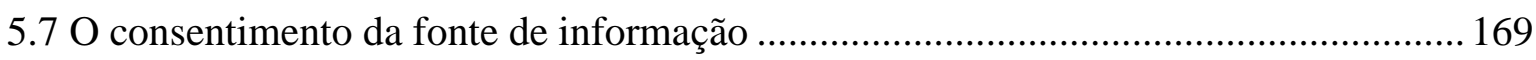

5.8 Limite ao dever de testemunhar. O princípio do nemo tenetur ................................. 170

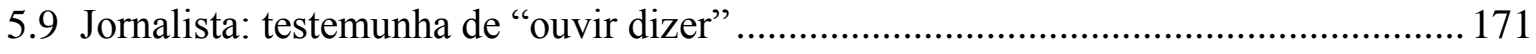

5.10 A busca e apreensão do material de trabalho e a interceptação telefônica do jornalista.

\section{SIGILO DA FONTE: UM LIMITE PROBATÓRIO} (IN) SUPERÁVEL?

6.1 A regulamentação do segredo jornalístico no Código de Processo Penal Italiano

$6.2 \mathrm{O}$ incidente de quebra de escusa do depoimento jornalístico no Código de Processo Penal Português 
6.3 O testemunho do jornalista nos processos de crimes contra a humanidade 184

6.3.1 As fontes das notícias sobre a guerra

6.3.2 Por uma regulamentação processual internacional do segredo da fonte. 188

6.4 A questão do sigilo da fonte na internet. 191

$6.5 \mathrm{O}$ sigilo da fonte como regra de direito fundamental:

consequências da opção do constituinte brasileiro 193

6.5.1 Revelar ou não a fonte: um dever ético? 194

6.5.2 A impossibilidade de aplicação do princípio da proporcionalidade. 195

6.5.3 A jurisprudência brasileira 199

6.5.4 A responsabilidade do jornalista pelos abusos na informação. 201

CONCLUSÕES .204

REFERÊNCIAS BIBLIOGRÁFICAS .209 


\section{INTRODUÇÃO}

Há poucos temas que transcendem a relação entre o ser humano e o poder político do Estado, como a prova no processo penal. Muito além de ser preciso reconstruir os fatos passados, para embasar um direito à liberdade do acusado ou um dever de punir estatal, existe uma necessidade ínsita no indivíduo de fazer prevalecer a sua verdade sobre os acontecimentos, perante si e perante os outros. Falar em um direito à prova, portanto, é falar em um direito a sustentar valores pessoais, provando os fatos diante da vida e no processo.

É na atividade probatória do processo penal que se verifica uma premência na efetivação dos princípios constitucionais garantidores da dignidade do acusado, para a realização de um processo justo, no qual o equilíbrio entre o exercício do poder punitivo estatal e a defesa do indivíduo seja um realizável ideal de justiça. Mas a justiça aqui desejada é também uma exigência, tem um sentido de valor, que ultrapassa o limite da simples conformidade com o estabelecido na lei.

A prova é, pois, o elemento essencial na realização da justiça pelo processo, sem a qual o Estado não encontraria solidez na legitimação de seu poder de punir, e o indivíduo, acusado de crime, dela depende para a efetivação do seu direito à liberdade.

A forma como o ordenamento jurídico estrutura a normatização do direito das partes à prova, a possibilidade de buscar elementos para embasar a verdade histórica, bem como a imposição de limites à atividade probatória visando à proteção dos direitos fundamentais, vai revelar o grau de democracia existente em um Estado de Direito.

O processo penal deve assumir contornos constitucionais como a alma da sua existência estrutural, impondo no desenvolvimento e na solução prática dos conflitos a marca dos princípios que regem a base democrática da sociedade na qual se insere.

No âmbito do direito à prova, a possibilidade de efetiva participação do acusado no exercício do poder punitivo estatal, realizando, na plenitude, a sua defesa no processo 
penal, com amplo acesso ao conhecimento e produção de provas que poderão trazer à luz a verdade dos fatos, sempre protegido por garantias que assegurem a sua dignidade humana, é o modelo desta estrutura processual com dimensão democrática.

Todavia, a análise desse direito envolve a polêmica questão do limite à apuração da verdade, o limite deste direito, o que pressupõe, por consequência, um limite ao ius puniendi do Estado, por um lado e, de outro, um limite ao direito de defesa do acusado.

A presente investigação tem por escopo analisar esse limite à prova no contexto da sociedade contemporânea da comunicação midiática. Devido à importância que a liberdade de informação assumiu no desenvolvimento do Estado Democrático de Direito instituído na Constituição brasileira de 1988, trazendo aos cidadãos a possibilidade de controle e participação na atuação estatal, através de uma mídia sem censura, há valores que se chocam, princípios que se contrapõem, que merecem análise e busca de soluções compatíveis com o modelo de regime político adotado.

A garantia da liberdade de informação pelos meios de comunicação é de tal relevância para o sistema democrático adotado pelo nosso país, que entendeu o legislador constituinte ser necessário protegê-la na sua efetivação. E uma das maneiras foi normatizar o segredo da fonte de informação jornalística, como direito fundamental, no art. $5^{\circ}$, inciso XIV da Constituição brasileira: "é assegurado a todos o acesso à informação $e$ resguardado o sigilo da fonte, quando necessário ao exercício profissional".

O segredo da fonte de informação jornalística é um tema que, historicamente, desenvolveu-se com a liberdade de imprensa. Diz respeito diretamente ao jornalista, pois, por vezes, no exercício profissional, proteger a origem da informação é o único meio de obtê-la e divulgá-la aos cidadãos. Eis a razão, aliás, pela qual o segredo do jornalista está vinculado com a democracia, regime político cuja viga mestra é a publicidade e transparência dos atos governamentais.

Os valores referidos, do direito à prova e do direito à informação pelos meios de comunicação, não se relacionam com tranquilidade no sistema jurídico. Essa a questão de fundo da tese, cuja ideia central é o limite ao direito à prova no processo penal, pelo 
segredo da fonte jornalística, que instrumentaliza a liberdade de imprensa, uns dos valores de capital importância para o desenvolvimento democrático.

A atualidade do tema evidencia-se a partir da positivação do sigilo da fonte na Constituição de 88 , que vem ao encontro do crescente desenvolvimento do que se denomina "jornalismo investigativo".

A realidade desse modo de fazer jornalismo, cujas notícias dão causa à instauração de inquérito e vêm colocando agentes públicos nos bancos dos réus, acusados em processos penais, leva à necessidade de se estudar a prova, sob um aspecto novo, com ritmo de entendimento e evoluções adaptados à sociedade de informação e à regulamentação constitucional da ampla liberdade de imprensa. Isso porque, além do direito que possui o profissional da mídia de buscar a informação para ser divulgada, há o direito tutelado constitucionalmente de não identificar a fonte da notícia, o que poderá impor ao acusado uma limitação de seu direito à prova.

A proposta do trabalho é verificar se, e como será possível compatibilizar a garantia constitucional do sigilo da fonte e a garantia do acusado de obter provas para sua defesa, quando a testemunha for um profissional da comunicação e, quando documentos necessários à comprovação dos fatos estiverem em poder do jornalista ou da redação do jornal. Evidencia-se, portanto, a dificuldade de conciliar valores tão relevantes num Estado Democrático de Direito.

Para tanto, o estudo do segredo da fonte de informação na sua dimensão democrática, como instrumento da liberdade de imprensa, será o foco do princípio do trabalho a nortear todo o desenvolvimento posterior.

Além disso, também será dado relevo ao estudo do segredo jornalístico no contexto da liberdade de expressão, no direito estrangeiro e no sistema jurídico brasileiro. O tema é pouco discutido entre nós, mas veremos que houve uma evolução do direito ao sigilo nas Constituições, até o enunciado normativo da Carta Magna de 1988, como expressão dos momentos políticos pelos quais passou o Brasil. Assim sendo, evidencia-se a preocupação do constituinte brasileiro e a importância da norma em apreço, seguindo a tendência das 
Cartas Políticas estrangeiras. Essa abordagem inicial do tema será feita nos dois primeiros capítulos.

A partir de então, abordaremos o modo como se busca a fonte e a prova da informação ali colhida para a elaboração da reportagem jornalística. Não será nosso objetivo aprofundarmos a questão sob a ótica da Comunicação Social, mas seu desenvolvimento, ainda que superficial, será necessário para demonstrar, em que medida ela se relaciona com prova penal. Assim, no terceiro capítulo, abordaremos a questão da "verdade" buscada pelo profissional da mídia, a qual possui método e objetivo distintos da verdade processual e, não obstante, acaba por servir como prova a ser utilizada para fundamentar a sentença penal.

No quarto capítulo, será estudado o direito à prova e a verdade no processo penal. A essencialidade do desenvolvimento do tema da busca da verdade processual, no presente trabalho, não servirá apenas para legitimar um poder estatal através da sentença, na medida em que os fatos constantes da acusação criminal são confirmados. Mas, também, para confrontar com a "verdade" dos fatos buscada pelos jornalistas, que não se traduz num valor, todavia, legitima a atividade do profissional da comunicação pela opinião, ou repercussão da notícia junto ao público.

A questão do segredo profissional como limite à prova terá por objetivo, neste capítulo, não só demonstrar que o próprio legislador relativizou a busca da verdade como valor de efetividade do processo, mas também esclarecer a maneira pela qual normatizou o equilíbrio de interesses sociais. Assim, priorizando as relações profissionais imprescindíveis para a convivência social, proibiu determinadas provas que infringissem suas escolhas dos bens ou valores merecedores de tutela legal.

Procuraremos, então, especificar as relações entre os meios de prova e o segredo das testemunhas previsto no artigo 207 do Código de Processo Penal. Demonstraremos que esses segredos protegem interesses individuais como a esfera da vida privada, a intimidade, a privacidade, a imagem e a honra, e também as relações necessárias para a convivência social. 
No quinto capítulo, demonstraremos que o sigilo jornalístico foi estabelecido pelo legislador constituinte por razões muito distintas dos outros segredos. Não pretendeu, prima facie, tutelar os direitos personalíssimos dos indivíduos, mas instrumentalizar com a tutela do anonimato do informante, o exercício do poder que emana do povo, o qual só é possível através da liberdade de imprensa. Essa a razão pela qual a sua relação com a prova no processo penal adquire característica e tratamento próprios.

Estudaremos o testemunho do jornalista, bem como a prova documental consistente no material por ele utilizado para elaboração da reportagem. Serão desenvolvidos o modo de produção e o valor desses meios probatórios no processo penal. Assim, no intuito de proteger a fonte de informação jornalística, se necessário e a critério do profissional, o procedimento probatório exigirá das partes e do juiz algumas especificidades, sob pena de a prova colhida ser considerada ilícita, se produzida com ofensa à regra constitucional prevista no art. $5^{\circ}$, XIV da CF.

Finalmente, estabelecida a diferença entre os segredos e as razões do legislador na proteção de valores diversos, no capítulo sexto, analisaremos as consequências, no processo penal, da opção do legislador brasileiro de normatizar o segredo da fonte da informação jornalística na Constituição de 88. Antes, porém, examinaremos como os Códigos de Processo Penal estrangeiros tratam o tema, extraindo daí possíveis argumentos jurídicos para possibilitar uma adequação do sigilo da fonte como limite à prova no processo penal brasileiro.

Com o progresso tecnológico dos meios de comunicação amplia-se, cada vez mais, o problema das questões relacionadas às fontes de prova, às quais também faremos alusão nesse último capítulo. As informações confidenciais vazadas do Departamento de Estado dos Estados Unidos da América, publicadas pelo WikiLeaks, com o impacto que teve na opinião pública mundial e nas relações com diversos países, as notícias anônimas divulgadas em redes sociais como blogs, facebook, twiter, workut, vão gerar discussões sobre a necessidade, ou não, de estabelecimento de limites para assegurar garantias processuais constitucionais de acusados de crimes.

Finalmente concluiremos o estudo posicionando-nos, a partir dos argumentos sustentadores das proposições desenvolvidas, sobre como é possível, no nosso entender, 
assegurar um efetivo direito à prova frente ao limite constitucional da confidencialidade da fonte de informação jornalística. Apresentaremos nossa posição acerca da possibilidade, ou não, de equilíbrio entre os valores objetos do tema, bem como a necessidade de regulamentação do sigilo da fonte pelo legislador processual penal. Eis a forma como desenvolveremos nossa tese. 


\section{O SIGILO DA FONTE NO CONTEXTO DA LIBERDADE DE INFORMAÇÃO}

\subsection{A dimensão democrática das "liberdades da comunicação"}

O ponto de partida do trabalho é a temática da liberdade de informação. A escolha se justifica, pois há uma nítida implicação com as liberdades de expressão do pensamento, de comunicação social e de imprensa, chegando, até mesmo, a confundirem-se no momento de suas concretizações. E é na liberdade de informação jornalística que, modernamente, as demais liberdades se exteriorizam.

$\mathrm{Na}$ doutrina, as diversas liberdades desenvolvem-se conceitualmente de forma individual, mas terminam confluindo para um único ponto, onde adquirem função estruturadora da ordem democrática. Aqui, portanto, vai emergir toda a dimensão e importância da efetividade dessas liberdades. De uma perspectiva inicial de direitos assegurados a toda pessoa, passam a ocupar, entre os direitos fundamentais, o núcleo do Estado democrático. ${ }^{1}$

A liberdade de informação, pelos meios de comunicação, tem sua origem na necessidade individual do ser humano de expressar seu pensamento. Pensar é um ato primeiro $^{2}$, anterior às demais manifestações das outras liberdades, estritamente individual, "que se produz no âmbito mais íntimo do homem"3, e consiste numa atividade psíquica de concepção, observação, percepção, racionalização e possibilidade de, através de

\footnotetext{
${ }^{1}$ Segundo Miguel Revenga Sánchez, "Hay teorías de la democracia que pueden resultar convincentes, pese a silenciar el sitio que en ella ocupan los derechos, pero ninguna teoría es posible sin una referencia, que a menudo es esencial, a la libre circulación de ideas y opiniones". Cf. Trazando los limites de lo tolerable: libertad de expresión y defensa del ethos democrático en la jurisprudência constitucional española. In: PIZZORUSSO, A.; ROMBOLI R.; RUGGERI, A.; SAITTA, A.; SILVESTRI G. (Coords.). Libertà di manifestazione del pensiero e giurisprudenza costituzionale. Milano: Giuffrè, 2005, p. 213.

${ }^{2}$ Celso Ribeiro Bastos esclarece que "A liberdade de pensamento, ou de opinião, é qualificada por alguns autores como simultaneamente primária e primeira, isto pelo fato de aparecer cronológica e logicamente antes de outras liberdades que não são senão um consectário seu." Cf. A liberdade de expressão e a comunicação social. In: Cadernos de Direito Constitucional e Ciência Política, São Paulo, ano 5, n. 20, p. 48, jul.-set. 1997.

${ }^{3}$ BADENI, Gregorio. Libertad de Prensa. 2 ed. actual. Buenos Aires: Abeledo-Perrot, 1997, p.11.
} 
conclusões, chegar, ou não, “consciente ou inconscientemente, ao conhecimento de um objeto material ou imaterial determinado" $"$.

Mas a natureza social do homem não atinge a completude com esse direito que, embora absoluto, irrestringível do livre pensar, só adquire consistência quando, na relação com os demais membros da sociedade, pode ele manifestar, expressar seu pensamento. $\mathrm{O}$ homem necessita comunicar-se, fazer conhecer aos outros o que elabora na esfera mais íntima do seu espírito.

A liberdade de expressão, então, é a possibilidade de exteriorização do pensamento, e da opinião. Corresponde a uma "marque de volonté", do ser humano de trazer à luz, de concretizar e de comunicar suas ideias.

Daí dizermos que, na sociedade do século XXI, essa liberdade não se traduz senão através da comunicação, cujo processo está em constante desenvolvimento. ${ }^{6}$ Dos folhetins à internet e à transmissão de informações via satélite, os processos de comunicação complementam a liberdade de imprensa, uma espécie da liberdade de expressão que é canalizada, publicamente, por meio dos jornais e demais meios técnicos de comunicação. A liberdade de comunicar o pensamento é, inclusive, a possibilidade de escolher a forma, o meio, o veículo para expressá-lo e difundir, também, a informação ${ }^{7}$.

Esse é o moderno e amplo sentido da liberdade de expressão, que a doutrina denomina "liberdades comunicativas ou liberdades da comunicação [...]. É um 'superconceito` [...] que abrange a liberdade de expressão em sentido estrito, por vezes

\footnotetext{
${ }^{4}$ BADENI, Gregorio. Libertad..., cit. p. 11.

${ }^{5}$ MORANGE, Jean. La liberte d expression. Paris: Presses Universitaires de France, 1993, p.11.

${ }^{6}$ Já dissemos em outra oportunidade que "a liberdade de expressão, decorrência natural da liberdade de pensamento, manifesta-se, inclusive, no campo da comunicação pública. O fundamento de toda sociedade de homens é a comunicação. É por meio dela que o ser humano estabelece a convivência - o viver em comum, compartilhando no grupo social ideias, sentimentos, valores, interesses e crenças. São pessoas interagindo, realizando o contato social, expandindo suas vidas". Cf. VIEIRA, Ana Lúcia Menezes. Processo Penal e Mídia. São Paulo: RT, 2003, p. 26.

${ }^{7}$ SILVA, José Afonso da. Curso de direito constitucional positivo. 33 ed. rev. atual., São Paulo: Malheiros, 2010, p.248.
} 
designada por liberdade de opinião, a liberdade de informação, a liberdade de imprensa, os direitos dos jornalistas e a liberdade de radiodifusão". ${ }^{8}$

É possível deduzir do texto constitucional brasileiro de 1988, a adoção desse sentido amplo da liberdade de expressão no artigo $5^{\circ}$, incisos IV, V, IX, XII e XIV, combinados com os artigos 220 a 224, os quais normatizam um elenco de direitos que coordenam a "manifestação do pensamento, a criação, a expressão e informação sob qualquer forma, processo ou veículo" que integram a liberdade de comunicação 9 .

Tais disposições normativas levam à consideração de que o direito à liberdade de expressão é "direito mãe, cluster right ou background right de todas as outras liberdades comunicativas" $" 10$. E, um dos aspectos desta, quando é dirigida ao público, concretiza-se em liberdade de informação, "representando uma mínima organização para a efetividade da relação entre sujeito emissor e receptor indiferenciado da informação"11.

Informação, como um dos elementos integrantes da liberdade de expressão ${ }^{12}$, em uma definição voltada para o processo da comunicação, para a transmissão e recepção da

${ }^{8}$ MACHADO, Jónatas E. M. Liberdade de Expressão. Dimensões constitucionais da esfera pública no sistema social. Coimbra: Coimbra Ed., 2002, p. 371.

${ }^{9}$ Sérgio Gardenghi Suiama, enfatiza que "ausente dos principais textos internacionais, a expressão 'direito à comunicação tem sido usada para enfatizar a interação que se desenvolve entre locutor e ouvinte, ou, de forma mais ampla, entre coletividades, todos participantes de processos sociais de significação e resignificação no interior de uma determinada comunidade jurídico-linguística. A locução é, portanto, mais abrangente do que as clássicas liberdades de expressão e informação, associadas antes à enunciação monológica isolada do que ao interdiscurso". Cf. O direito Fundamental à comunicação e o STF. In: AMARAL JÚNIOR, Alberto do; JUBILUT, Liliana Lyra. (Orgs.) O STF e o direito internacional dos direitos humanos. São Paulo: Quartier Latin, 2009, p. 233.

${ }^{10}$ MACHADO, Jónatas E.M. Liberdade...cit., p. 372. O autor, na nota 310, explica que não deu à expressão background rigths, de D OR IN, o sentido totalmente coincidente com o do autor. "Para D or in, os background rights caracterizam-se por providenciarem uma justificação para uma decisão de uma determinada instituição. E não há dúvida que nesta acepção se pode considerar a liberdade de expressão como background right, ao passo que outros direitos, como o direito de resposta, os direitos dos jornalistas e o direito de antena, por exemplo, como institucional rights. Todavia, o sentido que queremos dar à expressão utilizada pretende sublinhar o fato de que o relevo substantivo da problemática da liberdade de expressão constitui o pano de fundo ou o ambiente doutrinal em que se deve proceder à densificação interpretativa das diversas liberdades comunicativas".

${ }^{11}$ DÍAZ, Ramón Soriano. Las libertades públicas: significado, fundamentos y estatuto jurídico. Madrid: Tecnos, 1990, p. 108. Necessário assinalar, nesse ponto, a título de exemplo, que a Constituição espanhola traça uma distinção entre liberdade de expressão e informação: No seu artigo 20, "a" reconhece o direito "a expressar e difundir livremente os pensamentos, ideias e opiniões ...", como liberdade de expressão e, no artigo 20 "d", reconhece a liberdade de informação como o direito de "comunicar e receber livremente informação veraz por qualquer meio de difusão".

12 Para Luis Gustavo Grandinetti Castanho de Carvalho, "é importante sistematizar, de um lado, o direito de informação, e, de outro, a liberdade de expressão. No primeiro está apenas a divulgação de fatos, dados, qualidades, objetivamente apuradas. No segundo está a livre expressão do pensamento por qualquer meio, 
mensagem através de órgãos de imprensa ${ }^{13}$, é "o acontecimento ou fato de interesse geral tornado do conhecimento público ao ser divulgado pelos meios de comunicação; notícia [...] conjunto de atividades que têm por objetivo a coleta, o tratamento e a difusão de notícias junto ao público"14.

Ela possui uma dupla dimensão: uma individual e outra social. Como liberdade individual, caminha paralelamente com um direito à informação que na sociedade da comunicação de massa ${ }^{15}$ assume caráter social, coletivo ${ }^{16}$. O direito à informação, por sua vez, "não é um direito pessoal, nem simplesmente um direito profissional, mas um direito coletivo",17.

Significa dizer que, a dimensão individual da liberdade de informação compreende a utilização do meio necessário para fazer chegar às pessoas a expressão do direito de falar, pensar e ter ideias. E quando a liberdade de informação e a liberdade de expressão servem

seja a criação artística ou literária, que inclui o cinema, o teatro, a novela, a ficção literária, as artes plásticas, a música, até mesmo a opinião publicada em jornal ou em qualquer outro veículo [...] é preciso não confundir as duas essências: informação e expressão. Elas quase sempre coexistem em um mesmo veículo, com maior ou menor interação, mas devem ser examinadas sob pontos de vista diametralmente opostos: uma é imparcial, a outra é parcial; uma tem a função social de contribuir para elaboração do pensamento, a outra tem a função social de difundir um pensamento ou um sentimento já elaborado. São fronteiras tênues, mas existentes e que não devem ser ultrapassadas". Cf. Direito de informação e liberdade de expressão. Rio de Janeiro: Renovar, 1999, p. 25-26.

${ }^{13}$ Para um estudo sobre o processo da comunicação ver MELO, José Marques de. Teoria da comunicação: paradigmas latino-americanos. Petrópolis: Vozes, 1998. O autor ressalta na obra, que a informação constitui um dos elementos do processo da comunicação, é o objeto, o conteúdo a ser comunicado. Explica que a realização de intercâmbio de informações é o objetivo da comunicação entre as pessoas, razão pela qual não há comunicação sem informação (p. 60).; No mesmo sentido: BELTRÃO, Luiz; QUIRINO, Newton de Oliveira. Subsídios para uma teoria da comunicação de massa. São Paulo: Summus, 1986.

${ }^{14}$ HOUAISS, Antonio; VILLAR, Mauro de Salles; FRANCO, Francisco Manoel de Mello. Dicionário Houaiss da Língua Portuguesa. Rio de janeiro: Objetiva, 2001, p. 1615.

${ }^{15}$ No nosso trabalho sobre Mídia e Processo Penal dissemos que "a expressão comunicação de massa, universalmente consagrada, primeiramente evoca uma imagem de multidão, uma vasta audiência de milhões de indivíduos. Todavia, o que importa na comunicação de massa não está na quantidade de indivíduos que recebem os produtos, mas no fato de que estes produtos estão disponíveis em princípio para uma grande pluralidade de destinatários . Isto porque alguns meios de comunicação, como livros e determinadas revistas, possuem um público reduzido, bastante restrito. Assim, o termo massa pode ser associado a um grupo amplo e heterogêneo de indivíduos com características sociais diversas, sem liame de organização, sem interesses comuns e anônimos: desconhecidos não necessariamente entre eles, mas para os comunicadores". Cf. VIEIRA, Ana Lúcia Menezes. Processo...cit., p. 28-29.

${ }^{16}$ Os doutrinadores, embora apresentem divergências conceituais, distinguem liberdade de informação e direito à informação. Para José Joaquim Gomes Canotilho, há uma "liberdade de informação", pois as liberdades apresentam um traço específico da "alternatividade de comportamentos", podendo seu titular escolher entre informar, ou não. Cf. Direito constitucional. 6 ed. Coimbra: Almedina, 1996, p. 539.

${ }^{17}$ NOBRE, Freitas. Comentários à lei de imprensa. 4 ed. atual. São Paulo: Saraiva, 1989, p.6. 
para divulgar ideias, fatos em forma de notícias, tornam-se meios para a comunicação de $\operatorname{massa}^{18}$, adquirindo a outra dimensão, a social.

Nesse aspecto, como direito coletivo, temos a liberdade de imprensa que está relacionada à liberdade de expressão e à liberdade de informação. Sem menção expressa na Constituição de 1988, “com ela pretende-se designar, genericamente, todos os meios mecânicos, químicos ou electrónicos de impressão, reprodução e difusão de notícias e opiniões"19. Não é mais possível restringir o termo imprensa aos escritos, como tradicionalmente se faz, devendo ser compreendida na abrangência do desenvolvimento tecnológico, estendendo essa liberdade à internet e demais meios eletrônicos.

Portanto, as diferentes liberdades da comunicação, embora a doutrina e os textos normativos não as utilizem como sinônimos, elas interagem conceitualmente e, inclusive, são difíceis de delimitação no conteúdo, pois existe uma "conexão substantiva interna entre o direito à liberdade de imprensa e as demais liberdades de comunicação"20.

\subsection{Informação: liberdade ou direito?}

$\mathrm{Na}$ Constituição Federal de 88, no artigo $5^{\circ}$ temos as liberdades de manifestação do pensamento (inciso IV), da expressão e da comunicação (inciso IX) e de acesso à informação (inciso XIV). $\mathrm{O}$ art. 220, parágrafo $1^{\circ}$, normatiza a liberdade de informação jornalística.

Os doutrinadores não são unânimes na utilização dos termos liberdade ou direito, quanto à informação. No entanto, de uma análise perfunctória, é possível extrair-se do texto constitucional que a liberdade é a essência e os meios legais para efetivá-la na

\footnotetext{
${ }^{18}$ Aqui, a comunicação de massa deve ser entendida como processo de intercâmbio de notícias, informações, para "um grupo amplo e heterogêneo de indivíduos com características sociais diversas, sem liame de organização, sem interesses comuns e anônimos: desconhecidos não necessariamente entre eles, mas para os comunicadores" Cf. VIEIRA, Ana Lúcia Menezes. Processo...cit., p. 26. Para John B. Thompson, "o que importa na comunicação de massa não está na quantidade de indivíduos que recebem os produtos, mas no fato de que estes produtos estão disponíveis em princípio para uma grande pluralidade de destinatários". Cf. A mídia e a modernidade: uma teoria social da mídia. Tradução Wagner de Oliveira Brandão. Petrópolis: Vozes, 1998, p. 30.

${ }^{19}$ MACHADO, Jónatas E. M. Liberdade...cit., p. 507.

${ }^{20}$ MACHADO, Jónatas, E. M. Liberdade...cit, p. 517.
} 
convivência social são os direitos subjetivos. Assim, "a liberdade jurídica, que pode não coincidir plenamente com a liberdade filosófica, determina os atributos normativos de uma pessoa e confere os instrumentos, que são os direitos subjetivos, para o exercício dessas liberdades em suas relações com outras pessoas e com a organização política global"21.

O legislador constituinte assegurou a todos o direito às liberdades da comunicação, havendo entre os conceitos um "prolongamento lógico",22 e até mesmo, a utilização deles como sinônimos, embora não o sejam.

A liberdade de informação, desde a Declaração Universal dos Direitos do Homem de 1948, foi considerada um direito: “Artigo 19: Todo o homem tem direito à liberdade de opinião e expressão; este direito inclui a liberdade de, sem interferências, ter opiniões e de procurar, receber e transmitir informações e idéias por quaisquer meios $e$ independentemente de fronteiras". Com o mesmo conteúdo são as normas constantes do Pacto Internacional de Direitos Civis e Políticos (Nova Iorque, 1966) ${ }^{23}$ e da Convenção Americana de Direitos Humanos (São José da Costa Rica, 1969) ${ }^{24}$.

Com efeito, a livre informação garante um noticiar ou não, uma possibilidade de escolha do profissional da comunicação. Esse direito lhe é assegurado. Todavia, há um componente social ao direito à liberdade de informação, que passa a integrá-lo. Trata-se do direito de buscar a informação, de informar e de o público ser informado. Esses aspectos do direito à informação, ao integrar o direito à liberdade de informação, exigem um abandono do "postulado negativo da livre imprensa para um direito positivo da informação. O recebedor da informação deixa de ser um sujeito passivo do processo

${ }^{21}$ BADENI, Gregório. Tratado de libertad de prensa. Buenos Aires: LexisNexis, Abeledo-Perrot, 2002, p. 20. Importante a distinção que faz Badeni ao distinguir a liberdade jurídica da liberdade filosófica. Essa "é uma ideia representativa das aspirações individuais do homem, que se traduz em um presumido poder para fazer ou conseguir um resultado determinado, não se trata do conceito jurídico que tem relevância no direito positivo. A liberdade jurídica não é simplesmente essa concepção metafísica, ainda que com frequência ela seja utilizada para caracterizar o conceito jurídico da liberdade" (cit, p. 19-20).

${ }^{22}$ DOTTI, René Ariel. Proteção da vida privada e liberdade de informação. São Paulo: RT, 1980. p. 169.

23 “Artigo 19: 1. Ninguém poderá ser molestado por suas opiniões. 2. Toda pessoa terá o direito à liberdade de expressão; esse direito incluirá a liberdade de procurar, receber e difundir informações e idéias de qualquer natureza, independentemente de considerações de fronteiras, verbalmente ou por escrito, de forma impressa ou artística, ou por qualquer meio de sua escolha".

24 “Artigo 13: 1. Toda pessoa tem direito à liberdade de pensamento e de expressão. Esse direito compreende a liberdade de buscar, receber e difundir informações e ideias de toda natureza, sem consideração de fronteiras, verbalmente ou por escrito, ou em forma impressa ou artística, ou por qualquer outro processo de sua escolha" 
informativo, imitido na massificação dos órgãos de comunicação, e recompõe-se como sujeito ativo, sujeito de direitos, titular do direito de ser informado [...] $]^{, 25}$.

Se a informação jornalística - que integra o objeto do nosso estudo - é regida pela liberdade de agir, de informar, de buscar, pela liberdade de escolha do meio ou conteúdo do que se pretende noticiar, também se caracteriza como um direito de informar a sociedade, destinatária única do processo de comunicação.

Portanto, tendo em vista a tênue diferença conceitual entre direito e liberdade de informação, no decorrer do trabalho usaremos um e outro termo procurando, na medida do possível, colocá-los no texto aproximando-os do seu significado doutrinário e legal.

\subsection{A liberdade de informação jornalística}

Alguns doutrinadores preferem a expressão "informação jornalística", sobretudo porque com o desenvolvimento dos meios de informação, não mais se justifica o uso do termo "imprensa", pois limitada à divulgação de notícias através do texto escrito ${ }^{26}$. Outros, por seu turno, relacionam o termo "informação jornalística" à atividade jornalística, sem abandonar a expressão "imprensa" ou "liberdade de informação"27. Durante o desenvolvimento do trabalho, porque entendemos mais técnico, usaremos a expressão informação jornalística quando nos referirmos à atividade do profissional da informação.

A liberdade de informação massiva - pelos meios de comunicação de massa - que assumiu características superadoras da liberdade de imprensa é, sem dúvida, a mais

25 CARVAlHO, Luis Gustavo Grandinetti Castanho de. Liberdade de informação e o direito difuso à informação verdadeira. Rio de Janeiro: Renovar, 1994, p. 50.

26 a opinião Luis Gustavo Grandinetti Castanho de Carvalho, para quem "a permanência do uso do termo imprensa só pode mesmo ser justificada como um tributo, uma concessão romântica à batalha política e jurídica que ela enfrentou para por cobro ao arbítrio político reinante em épocas passadas, em qualquer parte do mundo. Reconheça-se o mérito e compreenda-se o romantismo: em qualquer dos quadrantes da Terra, a imprensa lutou contra alguém ou contra um sistema [...] Os Governantes podem ter caído, os jornais podem ter sido fechados, os jornalistas podem ter sido fuzilados...mas a instituição imprensa sobreviveu a tudo e tornou-se indispensável à sociedade". Cf. Direito de informação...cit., p. 82.

${ }^{27}$ BIANCO, Rosanna. Il diritto Del giornalismo. Guida alla professione. Padova: CEDAM, 1997. 
importante de todas as formas das liberdades da comunicação ${ }^{28}$. Este conceito deu amplitude à liberdade de imprensa, devido, primordialmente, à evolução tecnológica e ao alcance social e político da atividade do processo de difusão de mensagens, transformadas em notícias destinadas à coletividade.

Originada no invento de Guttenberg, a partir do século XVI, a descrição histórica da liberdade de informação demonstra a responsabilidade do desenvolvimento dos meios para comunicar, na evolução da liberdade de imprensa. ${ }^{29}$ As novas tecnologias, os novos veículos de comunicação acabaram por modificar o comportamento das pessoas, afetando o desenvolvimento de formação cultural e a socialização, gerando uma formalização desta liberdade em textos jurídicos fundamentais dos Estados democráticos.

A evolução técnica impulsionou o desenvolvimento social dessa liberdade que teve relevante positivação jurídica em diversos textos. A liberdade de imprensa ${ }^{30}$, cujo termo é mais apropriado à época de seu crescimento, inclusive privilegiado sistematicamente como "manifestação paradigmática das liberdades de expressão e informação no contexto das sociedades contemporâneas" 31 , desenvolveu-se, sobretudo, a partir do século XVIII no período da Revolução Francesa. Em 1789 recebeu proteção na Declaração dos Direitos do Homem e do Cidadão, em cujo art. 11 constou que "a livre comunicação dos pensamentos e das opiniões é um dos direitos mais preciosos do homem; todo cidadão pode, portanto, falar, escrever e imprimir livremente, salvo a responsabilidade que o abuso dessa liberdade produza nos casos determinados por lei”. Mas, anteriormente, na Declaração de Direitos de Virgínia de 1776, em seu artigo 12, pela primeira vez na história das

${ }^{28}$ Afirma Fábio onder Comparato que "além do direito de informação, vai se firmando também, em vários países, um direito da comunicação social, vale dizer a prerrogativa, reconhecida a qualquer cidadão ou grupo legalmente organizado, de exprimir idéias, críticas ou mensagens de toda sorte através dos veículos de comunicação de massa [...] . A originária liberdade de expressão ou imprensa acabou esbarrando, na sociedade de massas, num obstáculo técnico insuperável: o acesso aos meios técnicos de difusão das mensagens". Cf. Nótula sobre o direito à comunicação social. Cf. CAVALCANTI FILHO, José Paulo (Org.). Informação e Poder. Ampla liberdade de informar X Responsabilidade no exercício dessa liberdade. Rio de Janeiro: Record, 1994, p. 67.

${ }^{29}$ A história testemunha a transformação da sociedade em virtude da evolução e desenvolvimento dos meios comunicativos de informação. Sobre o tema ver ALBERT P. e TERROU, F. História da imprensa. Trad. Edison Darci Heldt., São Paulo: Martins Fontes, 1990.

${ }^{30}$ Sobre a trajetória dos direitos à informação e à comunicação, ver FERREIRA, Aluízio. Direito à informação e direito à comunicação: direitos fundamentais na Constituição brasileira. São Paulo: Celso Bastos Editor: Instituto Brasileiro de Direito Constitucional, 1997; NOBRE, Freitas. Imprensa e Liberdade. Os princípios constitucionais e a nova legislação. São Paulo: Summus, 1988.

${ }^{31}$ ANDRADE, Manuel da Costa. Liberdade de imprensa e inviolabilidade pessoal: uma perspectiva jurídicocriminal. Coimbra: Coimbra Ed., 1996, p. 40. 
declarações fundamentais dos direitos humanos, já havia sido reconhecida a liberdade de imprensa como "um dos grandes baluartes da liberdade e não pode ser restringida jamais, a não ser por governos despóticos". Nos Estados Unidos em 1791, a Declaração de Direitos, pela Primeira Emenda da Constituição contemplou a liberdade de expressão e de imprensa nos seguintes termos: “O Congresso não fará lei alguma referente à implantação de uma religião ou proibindo o culto de qualquer uma delas; nem lei que restrinja a liberdade de palavra, ou de imprensa; nem o direito do povo de reunir-se pacificamente; nem o de dirigir-se ao governo em demandas para a reparação de situações consideradas injustas".

Esses direitos individuais dos cidadãos, consagrados nas declarações, demonstram a importância para o desenvolvimento do indivíduo que possui, na generalidade dos textos, a faculdade de difundir ideias, manifestarem-se sem embaraço do Estado.

Verifica-se, ainda, nos textos acima mencionados, que há expressamente consagrado o direito de transmitir opiniões e informações, mas não de recebê-las, muito embora seja possível a dedução dessa vertente da liberdade de imprensa. Foi com a Declaração Universal dos Direitos do Homem e do Cidadão, de 1948, que o direito a ser informado foi expressamente normatizado. Assim, dispôs o artigo 19 que "todo homem tem direito à liberdade de opinião e expressão; este direito inclui a liberdade de, sem interferências, ter opiniões e de procurar receber e transmitir informações e ideias por quaisquer meios $e$ independentemente de fronteiras". ${ }^{32}$.

Nas suas vertentes de informar e ser informado, o direito de liberdade de informação é um direito social ${ }^{33}$, com alcance político, cuja razão de ser é o funcionamento

\footnotetext{
${ }^{32}$ Adequada a observação de Eduardo Novoa Monreal no sentido de que é possível se depreender dos textos de direitos humanos que o direito à informação está incorporado à liberdade de expressão. Diz ele que "há uma interpretação histórica: enquanto a comunicação interpessoal foi a única forma de comunicação humana, o direito à liberdade de opinião era o único direito à comunicação. Mais tarde, à medida em que se desenvolveram os grandes meios de comunicação, o direito a buscar, receber e publicar informação passou a ser a preocupação principal. Sob esse ponto de vista, a ordem dos direitos específicos enumerados no artigo 19 da declaração Universal dos Direitos do Homem traça uma progressão histórica: opinião, expressão e informação". Cf. Derecho a la vida privada y libertad de información: um conflito de derechos. México: Siglo Veintiuno, 1979, p. 142.

33 Aurelia Maria Romero Coloma, ao falar da importância da liberdade de informação, ressalta ser ela um dos grandes direitos da civilização atual. Cf. Derecho a la información y libertad de expresión: especial consideración ao processo penal. Barcelona: Bosch, 1984, p.49.
} 
do Estado democrático, na medida em que possibilita aos cidadãos, através das informações recebidas, formar opiniões e participar ativamente do $\operatorname{poder}^{34}$.

Com esta característica, a partir da Declaração dos Direitos do Homem de 1948, passou a integrar outros textos internacionais de maneira mais ampla e explícita. Assim, passou a constar da Convenção Europeia de Salvaguarda dos Direitos do Homem e das Liberdades Fundamentais, firmada em Roma no ano de 1950, do Pacto Internacional de Direitos Civis e Políticos de Nova Iorque de 1966, da Convenção Americana sobre Direitos Humanos de São José da Costa Rica, de 1969, o direito à liberdade de informação, compreendido como liberdade de buscar, receber, difundir e comunicar informações por quaisquer meios. $^{35}$

Temos, então, a partir da Declaração dos Direitos do Homem e do Cidadão, sobretudo nas últimas décadas, uma liberdade de imprensa que, de um direito individual do cidadão de emitir seu pensamento livremente, converte-se em um meio de comunicação de massa com função social, assumindo um predominante papel de ser um dos instrumentos de salvaguarda do regime democrático e do Estado de Direito.

Não há Estado democrático ${ }^{36}$ sem informação e essa, como expressou o Ministro Carlos Ayres de Britto, do Supremo Tribunal Federal, "em plenitude e de máxima qualidade" ${ }^{37}$ é um dos pilares nos quais se apoia a Democracia. ${ }^{38} \mathrm{O}$ outro pilar do modelo democrático de organização estatal, da Constituição de 88 é a "transparência e visibilidade

\footnotetext{
${ }^{34}$ Sobre a natureza política dos meios de comunicação de massa, relevante trabalhado foi desenvolvido por Modesto Saavedra López. Cf. La libertad de expresión en el estado de derecho: entre la utopia y la realidad. Barcelona: Ariel, 1987.

${ }^{35}$ Ver artigos 10,19 e 13 , respectivamente.

${ }^{36}$ A base do conceito de Estado Democrático, para Dalmo de Abreu Dallari, é a noção de "governo do povo, revelada pela própria etimologia do termo democracia”. Cf. Elementos de teoria geral do Estado. 22. ed. São Paulo: Saraiva, 2001. p. 145.

37 Medida Cautelar em argüição de descumprimento de preceito fundamental 130-7, Distrito Federal. Tribunal Pleno, 27/02/2008.

38 PAGLIARINI e AGOSTINI discorrem sobre o direito à informação nas sociedades democráticas, sustentando que caminham concomitantemente, ou seja, só há democracia se se garantir o livre acesso de todos aos meios de comunicação. Cf. PAGLIARINI, Alexandre Coutinho; AGOSTINI, Leonardo Cesar de. A relação entre regime democrático e direito à informação. In: Direitos Fundamentais e Justiça, Porto Alegre, RS, ano 3, n. 8, jul-set. 2009, p. 73-80.
} 
do poder" ${ }^{39}$ E não há visibilidade do poder se não há informação, elemento da inviolável liberdade de expressão que "é a maior expressão da liberdade"40 .

Não se concebe uma sociedade desenvolvida sem a livre comunicação das informações, havendo uma verdadeira dependência entre as instituições as quais, isoladamente, não se sustentam. Dworkin, sobre essa inter-relação entre sociedade e imprensa afirma que "as duas instituições aumentaram seu poder juntas, numa espécie de simbiose constitucional" $"$.

A sociedade, portanto, depende da informação para ser efetivamente democrática, enquanto essa organização social só se desenvolve e possibilita a legitimação do Poder estatal se o povo puder interagir com o governo. Para tanto, os cidadãos precisam estar bem informados, inclusive, sobre as questões governamentais. É essencial a transparência do poder em um sistema democrático, afinal, "o que a todos afeta por todos deve ser aprovado e conhecido, e se a democracia tem que significar algo mais que as outras formas de governo do ponto de vista do direito à informação do cidadão, esse algo mais só pode ser a transparência da gestão política"42.

Se a democracia constitucional brasileira é um sistema político no qual são asseguradas as garantias necessárias para realizar os direitos fundamentais dos cidadãos frente ao Estado, é necessário que haja interação entre os indivíduos e o poder estatal para a prática democrática. E a interação, nos tempos modernos, só se viabiliza com a comunicação $^{43}$.

A mudança substantiva que a Constituição de 88 trouxe para a convivência democrática brasileira exige uma interpretação da liberdade de imprensa mais compatível

\footnotetext{
39 Medida Cautelar em Arguição de Descumprimento de Preceito Fundamental 130-7, Distrito Federal. Tribunal Pleno, 27/02/2008.

${ }^{40}$ Carlos Aires de Britto, Ministro Relator da Medida Cautelar 130-7.

${ }^{41}$ DWORKIN, Ronald. $O$ direito da liberdade. São Paulo: Martins Fontes, 2006, p. 300.

${ }^{42}$ GONZÁLEZ, Santiago Sánchez. Los medios de comunicación y los sistemas democráticos. Madrid: Marcial Pons, 1996, p. 96.

${ }^{43}$ Importantes estudo sobre a democracia e os meios de comunicação: GONZÁLEZ, Santiago Sánchez. Los medios de comunicación y los sistemas democráticos. Madrid: Marcial Pons, 1996. FISS, Owen. La ironia de la libertad de expresión. Barcelona: Gedisa, 1999.
} 
com a nova realidade ${ }^{44}$. Nessa ótica, a consagração das liberdades de expressão e informação implica, necessariamente, a garantia do direito dos indivíduos de serem informados, de receberem ideias, notícias para integrarem-se socialmente.

Revela-se, sob esse ângulo, o significado constitucional do direito a receber informação ${ }^{45}$. Mais do que um direito fundamental individual, com previsão no artigo $5^{\circ}$, XIV da Constituição Federal, é um direito da coletividade, beneficiária da informação no Estado democrático ${ }^{46}$.

Estabelece-se uma necessária relação entre Estado e sociedade no contexto da comunicação social, obrigando-se o primeiro não somente à publicidade e transparência de suas ações, mas possibilitando um efetivo direito à informação correta e ampla a toda comunidade social. Para a realização desse mister, o Estado prescreve normas que asseguram as condições do processo da comunicação, partindo da proibição da censura, a qual impede qualquer restrição legal à "plena liberdade de informação jornalística em qualquer veículo de comunicação social" ( 1 , art. 220 da CF).

Por conseguinte, a participação da coletividade no processo democrático ${ }^{47}$, não se realiza somente com o direito à liberdade de informação, mas com a efetiva garantia desse direito. O legislador constituinte, ao assegurar a todos a possibilidade de aceder às informações, protege esse direito coletivo com o resguardo do "sigilo da fonte quando

\footnotetext{
${ }^{44}$ O Ministro do Supremo Tribunal Federal, Menezes Direito, na ADPF 130-MC/DF referiu-se à necessidade de uma "leitura moral da Constituição".

${ }^{45}$ Sobre o significado constitucional do direito a receber informação, normatizado na Constituição espanhola, v.p.t. Marc Carrillo, Cláusula de consciência y secreto profesional de los comunicadores. CARPIZO, Jorge; CARBONELL, Miguel (Coords.). Derecho a La información y derechos humanos. Estudios em homenaje al maestro Mario de La Cueva. México: Universidad Nacional Autónoma de México, 2000, p. 403.

${ }^{46}$ Para Marc Carrillo, "El derecho a recibir información no solo es um âmbito de derechos individuales sino que también presenta um contenido objetivo; pues tal como ponía de relieve La STC 26/96, este derecho encierra um contenido complejo: además de ser um derecho de libertad, es, a su vez, uma garantía institucional. Para el alto tribunal, el interes colectivo em la información se fundamenta em la garantia del derecho a comunicarla. Este derecho se concebe como uma libertad al servicio de una institución objetiva de aquel interes que no es outra que la opinión pública libre. En este sentido, si dicho interes no contribuye a la configuración de la opinión pública libre, el derecho a la información pierde dimensión constitucional". Cf. Cláusula de consciência ... cit. p. 404-405.

${ }^{47}$ Oportuna a lição de José Afonso da Silva ao explicar que na Constituição brasileira, ao contrário da Constituição portuguesa, o "democrático" qualifica o Estado, irradiando "os valores da democracia sobre todos os elementos constitutivos do Estado e, pois, também sobre a ordem jurídica. O Direito, então, imantado por esses valores, se enriquece do sentir popular e terá que ajustar-se ao interesse coletivo" Cf. Direito...cit. p. 119. E, sobre democracia, ensina Pontes de Miranda que essa somente existe com co-decisão. "Chama-se co-decisão a deliberação em comum, pelo povo ou por pessoas escolhidas do povo". Cf. Democracia, liberdade, igualdade: os três caminhos. 2. ed., São Paulo: Saraiva, 1979, p. 136.
} 
necessário ao exercício profissional". A outorga dessa proteção é dirigida, portanto, aos jornalistas, titulares privilegiados ${ }^{48}$ do direito à informação.

\subsection{As vertentes da liberdade de informação: direito de informar e ser informado}

Não pretendemos fazer um estudo aprofundado acerca das duas vertentes da liberdade de informação, mas interessa-nos, tão somente, realizar com certa precisão o sentido das expressões que compõem a informação jornalística.

Já dissemos que a liberdade de pensamento explica a liberdade de expressão e essas, por sua vez, fundamentam a liberdade de informação. ${ }^{49}$ Afirmamos, ainda, que as liberdades não interessam somente ao indivíduo, mas como direito social, reflete toda sua importância para a comunidade, diante do seu grande desenvolvimento e da função de interação entre as pessoas e entre essas e o Estado.

Não há outra maneira de os indivíduos participarem do núcleo social, de formarem uma consciência crítica a respeito de questões políticas, econômicas, culturais, entre outras, de participar do processo democrático através de seus representantes, se a liberdade de informação não se traduz no direito a ser informado. Esse direito pode ser entendido como a faculdade do ser humano a conhecer ideias, pensamentos, fatos, acontecimentos da vida social e política, através de qualquer meio de expressão ou comunicação ${ }^{50}$, assumindo, sem dúvida, uma expressão individual e outra democrática ${ }^{51}$.

${ }^{48}$ GUEDJ, M. Alexis. Liberté et responsabilités en droit européen et international. In:BEINGNIER, Bernard; LAMY, Bertrand de; DREYER, Emmanuel. (Directeurs) Traité de droit de la presse et des médias. Paris: LexisNexis, 2009, p. 137.

${ }^{49}$ MONREAL, Novoa. Derecho a la vida privada...cit. p. 143.

${ }^{50}$ Quanto à dimensão individual de se informar, digna de nota o que traz Jónatas Machado, "um aspecto interessante, neste contexto, prende-se com a relação que pode estabelecer-se entre este direito e a liberdade de circular livremente no país e de se ausentar dele. Esta questão colocou-se na jurisprudência constitucional norte-americana na decisão do caso Zemel v. Rusk, 381 U.S. 1 (1965), em que o Supremo tribunal, entendendo que a Constituição não garantia um direito irrestrito à recolha de informações, sustentou a decisão administrativa de recusa de um passaporte para Cuba a um cidadão americano que o tinha solicitado com o propósito de satisfazer a sua curiosidade sobre a situação em Cuba e tornar-se, desse modo, um cidadão mais informado". Cf., Liberdade...cit. p. 478, nota 652.

51 Afirma Inacio Ramonet, que "ninguém nega a indispensável função da comunicação de massa numa democracia, pelo contrário. A informação continua sendo essencial ao bom andamento da sociedade, e sabese que não há democracia possível sem uma boa rede de comunicação e sem o máximo de informações livres. Todo mundo está de fato convencido de que é graças à informação que o ser humano vive como um 
A possibilidade do debate de idéias, de divergência, de escolha, de influência do povo no poder, pressupõe uma consciência coletiva livremente formada e informada, para que a vontade preponderante dos indivíduos realize o ideal de Estado Democrático ${ }^{52}$. Os meios de comunicação participam da formação dessa consciência coletiva se puderem, livremente, exercer o mister de informar.

$\mathrm{Na}$ vertente do direito a ser informado a possibilidade de informar - e entramos aqui no âmbito do que Jónatas Machado designa "comunicação publicística efetuada através dos mass mídia" ${ }^{, 53}$ ou liberdade de imprensa - na atualidade, também é requisito que permite uma autêntica participação democrática na política estatal.

Para que a imprensa seja efetivamente livre e possa exercer o direito de informar, assim como o indivíduo, também possui o direito de se informar ${ }^{54}$. Temos aqui um elemento caracterizador da atividade dos jornalistas, que se traduz na possibilidade de, sem impedimentos, procurar, buscar, recolher informações, ter acesso a fontes, isto é, a tudo aquilo ou a toda pessoa que possa trazer consigo uma informação, para poder transmiti-la, divulgá-la.

O direito de informação jornalística, portanto, é mais do que liberdade de informar, é "o direito a obter, no confronto com os poderes públicos e com os particulares, as informações indispensáveis às relações políticas, econômicas e sociais de um cidadão numa sociedade democrática" ${ }^{, 55}$, é o direito de se informar.

ser livre”. Cf. A tirania da comunicação. 'Trad. Lúcia Mathilde Endlich Orth. Petrópolis, RJ: Vozes, 1999, p. 24.

52 Sobre a supremacia da vontade do povo como elemento integrante da democracia, destaca-se a exposição de Dalmo de Abreu Dallari no capítulo intitulado "Ideia atual de estado democrático" na sua obra :Elementos de teoria geral do Estado, 22 ed., São Paulo: Saraiva, 2001, p. 300 e seguintes.

${ }^{53}$ Liberdade...cit. p. 504.

54 O artigo 19 da Declaração Universal dos Direitos do Homem prevê que "Todo indivíduo tem direito à liberdade de opinião e de expressão, o que implica o direito a não ser inquietado pelas suas opiniões e o de procurar, receber e difundir, sem consideração de fronteiras, informações e ideias por qualquer meio de expressão". (grifo nosso). O texto reporta-se, primeiramente, às duas dimensões do direito de informação: o direito de informar e o direito de receber informação, esclarecendo que pode ser feito por qualquer meio de expressão, o que inclui os meios de comunicação. Relevante, ainda, o alcance que a norma dá ao direito de informação, facultando a possibilidade de acesso às fontes: procurar, receber (...) sem consideração de fronteiras. Cf. LEITE PINTO, Ricardo. Liberdade de imprensa e vida privada. Revista da Ordem dos Advogados, Lisboa, ano 54, n. 27, p. 40-41, 1994.

${ }^{55}$ PINTO, Ricardo Leite. Liberdade...cit., p. 55. 
$\mathrm{Na}$ Constituição brasileira apresentam-se nítidas as dimensões do direito à informação. Como expressão individual "é livre a manifestação do pensamento" (art. $5^{\circ}$, IV) e no aspecto coletivo, "é assegurado a todos o acesso à informação" (art. 5 , IV).

Como função social, essa liberdade tem como titular cada um dos membros da coletividade, bem como os meios de comunicação e os jornalistas. Esses, para exercerem a atividade profissional de contribuírem na formação de uma opinião pública livre, precisam ter assegurado o livre acesso às fontes. Aqui, o legislador constituinte criou norma protetiva do trabalho do jornalista ao "resguardar o sigilo da fonte, quando necessário ao exercicio profissional" (art. 5 , IV, 2 parte).

Portanto, a informação jornalística, caracterizada por transmitir ou divulgar fatos noticiáveis, foi "blindada" pelo legislador constituinte com a tutela do sigilo da fonte, verdadeiro instrumento de garantia da democracia ${ }^{56}$.

\subsection{O sigilo da fonte como instrumento da liberdade de informação}

Demonstraremos que o sigilo da fonte na Constituição brasileira é instrumento de desenvolvimento de uma sociedade democrática, pois possibilita e garante o princípio da liberdade de informação jornalística. É um dos pilares de sustentação da liberdade de imprensa e para ela é dirigida.

Se a liberdade de informação é direito protegido nos países democráticos, ainda que com maior ou menor intensidade, o qual se embasa na proibição da censura, a mesma garantia de proteção deve ser estendida ao processo de recolha de informações. O sigilo da fonte possui, então, uma relação instrumental com esse direito assegurado constitucionalmente, e o ordenamento jurídico deve ser provido de mecanismos, para que o profissional da imprensa cumpra sua tarefa de relevante interesse político. ${ }^{57}$

\footnotetext{
56 Nesse sentido, ARAÚJO, Luiz Alberto David; SERRANO NUNES JR., Vidal. Curso de Direito Constitucional. São Paulo: Saraiva, 1998, p. 77.

${ }^{57}$ VENTURA, Adrian. Libertad de expresion y garantias. Buenos Aires: La ley, 2009, p. 17-18.
} 
O segredo a ser preservado é um limite ao direito/dever de informação do jornalista e se apresenta como legítimo, aceito socialmente como útil "instrumento de preservação da democracia e na luta pela melhoria das condições de participação efetiva de todos na discussão política e nas decisões que dela decorram"58.

Quando se fala em sigilo, vem logo à mente a opacidade que se contrapõe à necessária publicidade dos atos governamentais na sociedade. Há certa resistência inicial, no contato com a aparente contradição, em aceitar que o sigilo da fonte é instrumento que garante e fortalece uma verdadeira política informativa. Chega-se, mesmo, a desconfiar da credibilidade da notícia que, mantendo sigilosa a fonte, tem a função de trazer à luz fatos que, na sociedade onde o poder é do povo, devem ser de conhecimento de todos. É o sigilo garantindo a divulgação do que não pode ser ocultado.

Mas, então, por que se protege o sigilo da fonte de informação jornalística? O que fundamenta essa garantia do profissional da mídia?

Em primeiro lugar, o segredo jornalístico é tema de grande atualidade no que concerne à proibição da censura ${ }^{59}$ prévia $^{60}$ aos meios de comunicação nas democracias ocidentais e, o seu reconhecimento insere-se nessa vedação normativa ${ }^{61}$. Ora, no processo informativo, está a difusão de informações no qual se inclui, também, a busca por qualquer meio, a pesquisa. Logo, a fonte de informação desprotegida, ou a violação da sua identidade é forma de exteriorização da censura, pois restringe a liberdade que deve ser

58 ALMINO, João. O segredo e a informação. Ética e politica no espaço público. São Paulo: Brasiliense, 1986, p. 106.

59 Para Ricardo Leite Pinto, a ausência de impedimentos, a proibição da censura, integra o conceito de liberdade de expressão que consiste na faculdade de transmitir ou comunicar informações a outrem. Cf Direito de informação e segredo de justiça no direito português. Revista da Ordem dos Advogados, Lisboa, ano 51, p. 512, julho 1991. Importante estudo sobre a censura, sua definição, história, sua inclusão no contexto social, ver MORANGE, Jean. La liberte d'expression. Bruxelles: Bruylant, 2009.

60 Néstor Pedro Sagüés faz relevante análise sobre a censura judicial prévia à imprensa no Estado Democrático, coloca a necessidade de, às vezes, haver a necessidade de seu uso para tutelar outros valores e, finalmente, traz a posição da Corte Interamericana de Direitos Humanos, sobre o assunto. Cf. Censura judicial previa a La prensa. Posición de La Corte Interamericana de Derechos Humanos. In: Biblioteca Jurídica Virtual del Instituto de Investigações Jurídicas de la UNAM. www.juridicas.unam.mx. Acesso em: 22 fev. 2011.

${ }^{61} \mathrm{Na}$ Constituição brasileira de 88 a liberdade de expressão e de comunicação é livre de censura (art. $5^{\circ}$, IX) e no capítulo "Da Comunicação Social" encontramos no art. 220, parágrafo 2 , norma que estabelece ser "vedada toda e qualquer censura de natureza política, ideológica e artística". A Convenção Americana de Direitos Humanos também proíbe, expressamente, a censura prévia, no seu artigo 13.2 e, em seguida, no artigo 13.5, prescreve que "não se pode restringir o direito de expressão por vias e meios indiretos (grifo nosso). 
assegurada. ${ }^{62}$ Por conseguinte, impor a revelação da fonte ao jornalista é uma forma de censurar a liberdade de imprensa, na medida em que pode impedir o profissional de ter amplo acesso à informação.

Acrescente-se, também, que é a verdade por detrás do segredo profissional, que fundamenta o sigilo jornalístico como instrumento indispensável para nossa democracia e para o fortalecimento do Estado de direito ${ }^{63}$. A pluralidade de opiniões que se forma com a participação da mídia não prescinde, na sua base, de elementos verdadeiros. Mas a verdade informada não possui conceito absoluto, é aquela mais completa possível, mais próxima da realidade dos acontecimentos, sem distorções ou inadequações que a transforme em meros rumores. E essa verdade aproximada dos fatos, no entanto, nem sempre será possível sem a garantia de que a fonte permanecerá oculta.

O sigilo da fonte, quando bem utilizado, garante a possibilidade de aceder à informação, o que é indispensável para o direito à liberdade de imprensa, mas não, necessariamente, protege a informação de qualidade. A notícia com maior qualidade, que demonstra a diligência do profissional que a buscou, e gera maior credibilidade social, é aquela identificada. A que oculta a fonte, embora legítima e relevante para a formação do Estado democrático de direito, nem sempre possui maior consistência informativa.

${ }^{62}$ Em 2007, na China, surgiu a questão da censura às informações por sites de buscas na internet. O maior sítio de busca, conhecido mundialmente - GOOGLE - criou versão censurada para os usuários chineses GOOGLE.CN - em relação às matérias concernentes a direitos humanos, entre outros temas "politicamente delicados". A Anistia Internacional denunciou a Google de participar, com a China, de censura aos resultados de alguns temas de busca, como os mencionados. Assim, a empresa estaria ajudando a reprimir a liberdade de informação na China. (http://web.amnesty.org/pages/internet-110506-action-est, acessado em 20.06.2011); Em 13 de janeiro de 2010, a China, mais uma vez, foi instada pela Anistia Internacional a acabar com a censura na internet, depois que a empresa Google afirmou que as contas de correio eletrônico de ativistas de direitos humanos foram alvos de ataques de hac ers. "A Amnesty Internactional vem pedindo às empresas que operam na China que respeitem o direito à liberdade de expressão dos usuários da Web e que não colaborem com as autoridades na censura à internet e na autorregulamentação do fluxo de informação. A China aplica uma ampla política de censura que inclui o filtro de palavras-chave concretas e de temas politicamente sensíveis, o que resulta no bloqueio de resultados concretos na internet, assim como no bloqueio total de um grande número de sites, incluindo sites de direitos humanos - como o da Amnesty Internacional -, que as autoridades consideram politicamente sensíveis". In: Amnesty Internacional. Comunicado à Imprensa. 13 de janeiro de 2010. Disponível em http://www.br.amnesty.org/?q=node/535, acessado em 26 de junho de 2011. Gregorio Badeni noticia que, em 1952, o I Congresso Mundial de Jornalistas reunido em Santiago do Chile, enumerou entre as restrições à liberdade de imprensa de caráter profissional, a prisão e as sanções que se aplicam aos jornalistas para obrigá-los a revelar as fontes de sua informação. Cf. Libertad...cit., p. 247.

63 ANDRADE JARDÍ, Julián. El derecho a la información, los derechos humanos y el periodismo. CARPIZO, Jorge; CARBONELL, Miguel (Coords.). Derecho a la información y derechos humanos. Estudios en homenaje al maestro Mario de La Cueva. México: Instituto de Investigación Jurídicas, 2000, p. 436. 
Andrade Jardí a compara aos "segredos das ostras": "com a informação privilegiada, a que tem uma fonte oculta, me passa como as ostras: em regra geral são boas, porém é raro encontrar uma pérola" ${ }^{\circ 4}$.

A identificação da fonte, portanto, deve ser a regra e quando necessário para fins do exercício da profissão, o sigilo é resguardado para que o direito à liberdade de imprensa se concretize na amplitude da sua importância. Daí a razão de o sigilo da fonte se firmar como instrumento democrático, pois torna eficaz, realiza o direito à informação.

Fundamenta, também, o sigilo profissional do jornalista, a circulação da informação na sociedade. A busca de informações, sem a proteção do sigilo, pode inibir as fontes receosas de ameaças, represálias e toda espécie de prejuízos pessoais que a identificação poderá gerar. A consequência é que poderia coibir a prática do jornalismo investigativo, o qual tem trazido a público as mazelas do poder econômico, as práticas de corrupção pelos gestores e funcionários dos Poderes da República.

Portanto, se se fecham as fontes porque o sigilo não é resguardado, "pode ofuscar o acesso à informação ${ }^{65}$, patrimônio comum de todos, e prejudicar seriamente a transparência do sistema democrático, que sem informação não pode consolidar-se"66 .

\subsection{Sigilo e segredo: diferenças conceituais}

Os indivíduos sempre tiveram a necessidade do uso de signos para que pudessem expressar as ideias, os sentimentos, a posse sobre as coisas, sobre as pessoas, a religião que professavam.

${ }^{64}$ ANDRADE JARDÍ, Julián. El derecho ...cit., p. 436.

${ }^{65}$ Segundo Adrian Ventura, sobre a proteção do segredo jornalístico, “ a partir da ideia de que seu mais amplo reconhecimento facilita a tarefa do direito de aceder à informação e do correlativo direito de difundila, os meios de comunicação e os jornalistas pretendem conservar o segredo jornalístico, não para ocultar informação, senão para poder aceder à informação reservada e divulgá-la. Os meios necessitam do segredo jornalístico e da informação que brindam as fontes. Ante a negativa de fornecer informação, o meio e o jornalista acede a ela e a revela, guardando para si um só aspecto dessa informação: a fonte" Cf. Libertad de expresion y garantias. Buenos Aires: La Ley, 2009, p. 29.

${ }^{66}$ QUIROGA LAVIÊ, Humberto. La protección de la intimidad y la regulación del secreto. CARPIZO, Jorge; CARBONELL, Miguel (Coords.). Derecho a la información y derechos humanos. Estudios en homenaje al maestro Mario de La Cueva. México: Instituto de Investigación Jurídicas, 2000, p. 507. 
A marca, ou a incisão, ou um signum sempre fez parte da história do homem. Os egípcios marcavam seus valores com desenhos de animais, de plantas e de objetos. Os signores expressavam o domínio sobre as coisas com o seu signum, o seu sigillo, a sua marca de propriedade sobre os escravos. A igreja tem na cruz o seu símbolo, o seu signum. A justiça tem a balança como seu símbolo. Enfim, toda a história da humanidade é marcada, talhada por símbolos que expressam, em cada época e em cada povo, suas preferências, suas tradições e valores.

Daí o significado de sigilo, do latim, sigillum, é diminutivo de signum que significa marca, sinal, “é uma forma especial de emblema, geral e pessoal (...) símbolo que uma pessoa física ou jurídica adota como seu segno especial para fazer uso próprio e exclusivo". 67

O sentido da palavra sigilo evoluiu com a história. Os atos legais do Estado eram, quase sempre, validados por testemunhas e posteriormente postos sob sigilo "para dar uma visível prova da autenticidade dos atos" ${ }^{\natural 6}$. Aos poucos, o sinal, o sigillum foi perdendo seu caráter absoluto de marca, e passou a significar, também, conteúdo, sobretudo nas relações jurídicas, políticas e administrativas as quais, se devessem ser feitas de maneira muito reservadas, ou quando uma deliberação do Poder deveria ser secreta, dispunha-se que o fosse sob sigillo secretissimo. ${ }^{69}$

Segredo, por sua vez, pode ser entendido como o conteúdo do sigilo, aquilo que está guardado sob sigilo e não pode ser divulgado. É "todo informe que alguém conserva voluntariamente" ${ }^{, 70}$, sem interesse de divulgar a outrem. Do latim secretum, "exprime o que se tem conhecimento particular sob reserva ou ocultamente"

Utilizaremos os termos, indistintamente, pois entre os conceitos há uma relação de conteúdo e continente, sendo o segredo a informação que não pode ser revelada, o conteúdo do que deve ser ocultado pelo sigilo. Esse é o instrumento que protege, que

${ }^{67}$ GRASSI, Carmelo. Sigillo(Origine e sviluppo storico del).Enciclopedia Giuridica Italiana. Milano: Società Editrice Libraria. 1925, v. XV, parte II, sez. II, p. 663.

${ }^{68}$ GRASSI, Carmelo. Sigillo...cit p. 679.

${ }^{69}$ GRASSI, Carmelo. Sigillo....cit p. 680.

${ }^{70}$ GONZAGA, João Bernardino. Violação de segredo profissional. São Paulo: Max Limonad, 1976, p. 17.

${ }^{71}$ SILVA, De Plácido e. Vocabulário jurídico, Rio de Janeiro: Forense, 1993, p. 182. 
assegura o segredo e, que se for rompido, traz a público a divulgação da informação secreta.

A diferença entre os conceitos é de tal maneira tênue, que preferimos aceitá-los como sinônimos ${ }^{72}$, exatamente como encontramos no vernáculo, isto é, segredo "é aquilo que a ninguém deve ser revelado, que é secreto, sigiloso"73.

A noção sobre os termos que ora propusemos, necessária para fins de um trabalho científico, servirá, sobretudo, para melhor delimitarmos o significado de sigilo ou segredo, no âmbito da norma constitucional que o resguarda. Será objeto de estudo, não só o conteúdo normativo, mas, inclusive, a abrangência da expressão sigilo da fonte, ou seja, o que pode ser considerado segredo para fins de trabalho jornalístico.

\subsection{Segredo da fonte: um interesse social}

O sigilo profissional do jornalista é o direito de não revelar, de reter a informação em relação às fontes e compreende, por sua vez, a proteção das fontes informativas.

Ao escrever sobre uma "teoria geral" do direito ao segredo, Martínez-Villalba aponta a necessidade de delimitar os elementos que o compõe. Segundo o autor, a existência de segredo pressupõe, ao menos, a possibilidade de acesso à informação, e que deve ser de conhecimento exclusivo de alguma, ou de poucas pessoas. Deve haver o cuidado, por parte do profissional, à reserva, à manutenção do segredo, e finalmente, é imprescindível a existência de posse material da informação ${ }^{74}$. Por seus elementos, o segredo é definido como "a informação oculta e reservada que possui a fonte" ${ }^{\text {"75 }}$.

\footnotetext{
72 CENEVIVA, Walter. Segredos profissionais. São Paulo: Malheiros, 1996, p. 19.

${ }^{73}$ HOUAISS, Antonio; et al. Dicionário...cit. p 2535.

${ }^{74}$ Para o mencionado autor, a posse meramente material da informação não implica seu conhecimento, mas tão só a capacidade de acesso a ela, como acontece, por exemplo, com a informação eletromagnética guardada em um cartão ou disquete, ou pendrive. Cf. MARTíNEZ-VILLALBA, Ruan Carlos Riofrío. El derecho de los secretos:postulado de uma teoria general, p. 3. Disponível em: www.ibero-americano.org. Acesso em: 30 set. 2010.

${ }^{75}$ MARTÍNEZ-VILLALBA, Ruan Carlos Riofrío. El derecho...cit, p.3.
} 
Portanto, a informação que se oculta, o segredo, é a fonte. E a tutela jurídica recai somente sobre aquele segredo, no qual a fonte guarda um interesse legítimo, um interesse reconhecido pelo direito. ${ }^{76} \mathrm{E}$ o direito a não revelar a fonte surge quando existe esse interesse legítimo na manutenção do segredo.

Temos, por um lado, o direito do jornalista ao segredo da fonte, o direito de não revelar quem detém a informação divulgada, ou onde se encontra o material de retenção da informação que é notícia. Por outro, é possível falarmos em um direito da própria fonte de manter-se oculta, anônima. Os acontecimentos, determinados fatos, são trazidos aos jornalistas e explicados pelas fontes, daí a importância dessas no processo informativo e a necessidade de proteção do direto à reserva de suas identidades.

O direito de a fonte não ter sua identidade revelada, encontra-se na esfera de interesses privados de proteção à intimidade, à privacidade, à liberdade individual e de todas as consequências pessoais que daí decorrem para a vida do informador. Tais direitos, no entanto, têm como razão última o próprio direito à conveniente informação do público, o que justifica a garantia constitucional do sigilo assegurado ao jornalista.

Podemos concluir, portanto, que o direito ao anonimato que possui a fonte, muito além de proteger o interesse do indivíduo a conservar sua própria esfera de privacidade, vai assegurar o interesse público à informação, pois essa poderá fluir, sem reservas, atingindo sua função social de bem informar os cidadãos.

Por derradeiro, se o sigilo resguardado ao profissional do meio de comunicação é instrumento de democracia, pois possibilita a liberdade de imprensa, o direito da fonte à ocultação de sua identidade instrumentaliza o trabalho do jornalista e, por via reflexa, compõe os meios de efetivação dos ideais de um Estado Democrático de Direito que é, entre outros, a realização de direitos afirmados por normas ${ }^{77}$. Isso porque, uma sociedade bem informada possui condições de exigir dos Poderes públicos a concretização dos seus direitos, que estão tutelados no arcabouço legislativo estatal.

\footnotetext{
${ }^{76}$ Op. cit, p.4.

${ }^{77}$ Norberto Bobbio afirma que "o problema grave de nosso tempo, com relação aos direitos do homem, não era mais o de fundamentá-los, e sim o de protegê-los". Cf. A era dos direitos. Trad.Carlos Nelson Coutinho. Rio de Janeiro: Campus, 1992, p. 25. Parece-nos que enfrentamos outro problema na atualidade, que não é o de proteção dos direitos, mas de sua efetiva realização.
} 


\subsection{Sigilo da fonte como direito humano fundamental}

Não nos parece possível falarmos de proteção legal do sigilo, apartada do contexto normativo da liberdade de expressão e informação, uma vez que é instrumento de realização desta em todo o mundo.

A partir do desenvolvimento da então liberdade de imprensa durante o "século das luzes", quando se lutava contra a censura e se pregava a mais ampla liberdade de expressão das ideias, essa ainda incipiente foi cercando-se de garantias.

Como "um dos grandes baluartes da liberdade" sem possibilidade de restrição, como dispunha o art. 12 da Declaração de Direitos de Virgínia, de 1776, a livre comunicação dos pensamentos e opiniões passou a ser normatizada nos textos de direitos humanos.

"Fundamento de toda a liberdade"78, a livre comunicação dos pensamentos e opiniões foi considerada, na Declaração dos Direitos do Homem e do Cidadão, de 1789, un des droits le plus précieux de l'homme.

Já entendida como direito fundamental e pressuposto de outras liberdades, procurou-se garantir a liberdade de expressão e informação de maneira mais abrangente. E, porque as Declarações, como manifestações de princípios, valem "como meros enunciados sem criar obrigações jurídicas [...] e justamente à vista de sua insuficiência prática para a real garantia dos direitos humanos" ${ }^{, 79}$, firmaram-se Pactos e Convenções para a concretização das normas ali inseridas.

A Convenção Europeia de Salvaguarda dos Direitos do Homem e das Liberdades Fundamentais, firmada em Roma, em 1950, estabeleceu no artigo 10, 1, o direito à liberdade de expressão, compreendendo as liberdades de opinião, bem como de receber ou de comunicar informações e ideias. No mesmo artigo, item 2, fixou condições restritivas às

${ }^{78}$ COSTA ANDRADE, Manuel da. Liberdade de imprensa e inviolabilidade pessoal: uma perspectiva jurídico-criminal. Coimbra:Coimbra Ed., 1996, p. 44.

${ }^{79}$ GRINOVER, Ada Pellegrini. Liberdades públicas e processo penal: as interceptações telefônicas. 2. ed. São Paulo: RT, 1982, p. 82 e 84 
liberdades, desde que previstas em lei e que "[...] constituam providências necessárias, numa sociedade democrática, para a segurança nacional, a integridade territorial ou a segurança pública, a defesa da ordem e a prevenção do crime, a proteção da saúde ou da moral, a proteção da honra ou dos direitos de outrem, para impedir a divulgação de informações confidenciais, ou para garantir a autoridade e a imparcialidade do poder judicial". Portanto, já começam a ser fixadas as formas de exercícios dessas liberdades, possibilitando suas efetivas concretizações.

O Pacto Internacional de Direitos Civis e Políticos, aprovado em $1966^{80}$ pela Assembléia Geral das Nações Unidas, também normatizou a liberdade de expressão, compreendido este direito como "a liberdade de buscar, receber e difundir informações", por qualquer meio (Artigo 19, § 2.).

Releva mencionar que as liberdades de expressão e informação foram garantidas às crianças, no artigo 13 da Convenção Internacional sobre os Direitos das Crianças, adotada pela Assembléia Geral da Organização das Nações Unidas em 20 de novembro de 1989. Para tanto, no artigo 17, foram atribuídos aos Estados Partes o reconhecimento da importante função que desempenham os meios de comunicação, atribuindo-lhes a obrigação de velar para que a criança tenha acesso à informação e a material procedentes de diversas fontes nacionais e internacionais, sobretudo àqueles que tenham a finalidade de promover seu bem-estar social, espiritual e moral, e de saúde física e mental.

Anotamos, também, que a Convenção Americana de Direitos Humanos de 1969, assinada em São José da Costa Rica, estabelece em seu artigo 13 que "1. Toda pessoa tem direito à liberdade de pensamento e expressão. Este direito compreende a liberdade de buscar, receber e difundir informações ideias de toda indole [...]". Estabelece, também, no artigo 13, 2, a proibição de censura prévia no exercício da liberdade, bem como a impossibilidade de restringir o direito de comunicação e circulação de ideias e opiniões, por qualquer meio indireto.

\footnotetext{
${ }^{80}$ Segundo Flávia Piovesan o Pacto Internacional dos Direitos Civis e Políticos, entrou em vigor, tão somente em 1976, quando alcançou o número de ratificações necessário. Cf. Direitos humanos e o direito constitucional internacional. São Paulo: Max Limonad, 1996, p. 178.
} 
Em todos os instrumentos de proteção dos direitos humanos, como vimos, está incluída a liberdade de expressão, nas vertentes de informar, ser informado e informar-se, não obstante concebida, em cada texto, de maneira distinta. Todavia, as disposições transcritas dão conta, também, da ausência de previsão expressa de proteção às fontes de informação jornalística.

No entanto, as garantias da liberdade de informação começam a ser fixadas em Declarações e Princípios. Em agosto de 1994, na Cidade do México, foi aprovada a Declaração de Chapultepec $^{81}$ sobre a liberdade de imprensa, cujos princípios são referências sobre a importância desta no Estado Democrático de Direito. No terceiro princípio do texto, foi expressamente assegurado o sigilo da fonte: "As autoridades devem estar legalmente obrigadas a por à disposição dos cidadãos, de forma oportuna e equitativa, a informação gerada pelo poder público. Não poderá obrigar-se a nenhum jornalista a revelar suas fontes de informação"(grifamos). A Declaração, então, ressaltou o valor da liberdade de expressão e de imprensa em uma sociedade livre, daí derivando o direito a buscar e receber informações, com especial proteção do direito ao sigilo das fontes ${ }^{82}$ como instrumento de eficácia daquela liberdade.

Em 16 de novembro de 2000, a ONU e a OEA, por suas Relatorias sobre Liberdade de Expressão, além de várias organizações internacionais de defesa da liberdade de expressão, estabeleceram os Princípios de Lima nos quais foi incluído o de Proteção das fontes jornalísticas $\left(6^{\circ}\right)$ : “Nenhum jornalista pode ser obrigado pelo Poder Judiciário, ou

${ }^{81}$ A Declaração de Chapultepec, formulada pela Conferência Hemisférica sobre a Liberdade de Expressão, realizada em 1994 sob a presidência do ex secretário geral da Organização das Nações Unidas, Javier Pérez de Cuéllar, foi subscrita pelos Presidentes da Argentina, Guatemala, México, Panamá, Paraguay, Uruguay e o secretário geral da Organização dos Estados Americanos, João Baena Soares. Hoje, mais de 40 países a subscreveram, inclusive o Brasil, pelos Presidentes Fernando Henrique Cardoso, em 1986 e Luis Inácio Lula da Silva, em 2006. Cf. http://www.declaraciondechapultepec.org. A Declaração de Chapultepec não tem o rigor dos cânones de tratados e acordos internacionais, é um acordo informal, não convencional, no entanto, referida em vários pronunciamentos da Comissão Interamericana de Direitos Humanos e da Relatoria sobre a Liberdade de Expressão, além das decisões judiciais dos diversos países que a subscreveram. Cf. AGUIAR, Asdrúbal. La libertad de expresión, de Cádiz a Chapultepec. Caracas: SIP y Universidad Católica Andrés Bello, 2002, p. 87.

82 "Declaração de Chapultepec: Princípio um: "Não há pessoas nem sociedades livres sem liberdade de expressão e de imprensa. O exercício desta não é uma concessão das autoridades; é um direito inalienável do povo"; Princípio dois: "Toda pessoa tem direito a buscar e receber informação, expressar opiniões e divulgálas livremente. Nada pode restringir ou negar estes direitos". Cf. http://www.declaracióndechapultepec.org/v2/. Ver ainda em NESPRAL, Bernardo. Periodismo judicial: Periodismo y derecho. Buenos Aires: García Alonso, 2005, p. 40-41. 
qualquer outro funcionário ou autoridade pública a revelar suas fontes de informação ou o conteúdo de seus apontamentos e arquivos pessoais e profissionais". ${ }^{83}$

A Comissão Interamericana de Direitos Humanos, em outubro de 2000, aprovou a Declaração de Princípios sobre Liberdade de Expressão, documento que reafirma o artigo 13 da Convenção Americana de Direitos Humanos e reconhece "a necessidade de proteger efetivamente a liberdade de expressão nas Américas [...]” (Preâmbulo). O Princípio 8 afirma que "todo comunicador social tem direito à reserva de suas fontes de informação, apontamentos e arquivos pessoais e profissionais". ${ }^{84}$

Diversos informes da Comissão IDH, redigidos pela Relatoria Especial, mencionam a necessidade de proteção do segredo da fonte, fazem advertência sobre leis gerais que obrigam a revelação da fonte, busca e apreensão de materiais jornalísticos que serviriam para esse fim, interceptação telefônica de jornalistas e prisões por negativas de identificar a fonte. $^{85}$

A proteção das fontes dos jornalistas foi inscrita na Declaração de Joanesburgo no princípio 18, nos seguintes termos: “A protecção da segurança nacional não pode ser utilizada como razão para obrigar um jornalista a revelar uma fonte confidencial". ${ }^{86}$

${ }^{83}$ Disponível em http://www.consejoprensaperuana.org.peru/images/content/docs/decplima.pdf. Acesso em: 12 jul.2011. No Preâmbulo da Declaração de Princípios consta o reconhecimento das importantes iniciativas adotadas pela sociedade civil, para fazer efetivo esses direitos, bem como os esforços que fazem os Relatores Especiais para a Liberdade de Expressão das Nações Unidas e da OEA para promover e proteger as liberdades de expressão e informação.

84 Disponível em http://ww.cidh.oas.org/relatoria/showarticle.asp?artID=26\&IID=4. Acesso em: 12 jul. 2011. Interpretando o Princípio 8, Adrian Ventura ressalta a importância do direito que possui o comunicador social de negar-se a revelar suas fontes de informação, bem como o que obteve nas suas investigações, a entidades privadas, terceiros, autoridades públicas ou judiciais. Cf. Libertad...cit., p. 329.

${ }^{85} \mathrm{Cf}$. "Informe del relator especial para a libertad de expresión". In: Informe anual 2001, cap. II, Disponível em http://www.cidh.org/Relatoria/Spanish/InformeAnual/InfAnRe101/CapII2001.htm>, $\$ \S 108$ e 110. Acesso em: 18 de jun. 2011.

${ }^{86}$ Os Princípios de Joanesburgo Segurança Nacional, Liberdade de Expressão e Acesso à Informação, foram adotados em 1 de Outubro de 1995, e "reconhecem a aplicabilidade contínua dos Princípios de Siracusa sobre as Disposições de Limitação e Derrogação no Pacto Internacional sobre os Direitos Civis e Políticos e as Normas Mínimas de Paris sobre Direitos Humanos num Estado de Emergência” (Introdução). Disponível em http://www.cidh.org/relatoria/showarticle.asp?artID=133\&IID=4. Acesso em: 03 de jul. 2011. Trata-se de um documento "divulgado e integrado numa série dedicada à lei de imprensa e à prática dos média nos países pertencentes à Comunidade para o Desenvolvimento da África Austral (SADC)". Cf. http://article19.org/pdfs/standards/johannesburg-principles-port.pdf. Acesso em: 03 jul. 2011. 
O direito ao sigilo da fonte também foi consagrado, expressamente, na Resolução sobre as liberdades jornalísticas e dos direitos do homem, adotada na $4^{\mathrm{a}}$ Conferência Ministerial Europeia sobre a política das comunicações de massa (Praga, 7-8 de dezembro de 1994) e na Resolução do Parlamento Europeu sobre a não divulgação das fontes jornalísticas, de 18 de janeiro de $1994 .^{87}$

Em forma de Recomendação de 8 de março de 2000, o Comitê dos Ministros do Conselho da Europa sugeriu que os Estados membros dispusessem sobre a proteção do direito dos jornalistas ao segredo de suas fontes, considerando ser "condição ou garantia da liberdade de expressão e do direito do público à informação, essencial numa sociedade democrática". ${ }^{88}$

O direito à reserva da identidade das fontes, como veremos, encontrado nas Declarações de direitos referidas, vem expresso em algumas Constituições e, deriva da norma genérica e ampla da liberdade de informação, conforme decisões das Cortes Internacionais de Direitos Humanos.

\subsection{A garantia do sigilo da fonte de informação jornalística na Constituição brasileira}

Necessário considerar, primeiramente, que a garantia do sigilo da fonte, inserida na Constituição brasileira de 1988, decorreu de profundas modificações no modo de orientarse o país quanto à questão da liberdade de informação e expressão.

Assim, o direito ao anonimato da fonte é reconhecido, tão somente, quando a imprensa passa a existir, segundo Rui Barbosa, como "a vista da Nação"89, necessitando de um instrumento garantidor de sua efetividade.

Verificaremos, portanto, como a questão foi tratada nos textos legislativos constitucionais brasileiros, cujas ideias e momentos políticos de suas elaborações

\footnotetext{
${ }^{87}$ DERIEUX, Emmanuel. GRANCHET, d'Agnès. Droit des médias. Droit Français, Européen et International. 6.ediction, Paris: Lextenso, 2010, p. 959, nota 9.

${ }^{88}$ DERIEUX, Emmanuel. Droit Européen et Internacional des médias. Paris: L.G.D.J., 2003, p. 180.

${ }^{89}$ Cf. in: A imprensa e o dever da verdade. São Paulo: Ed. Papagaio, 2004, p. 32.
} 
definiram os contornos de amplitude, garantias e limites do expresso reconhecimento dessa liberdade de imprensa. ${ }^{90}$

\subsubsection{Evolução constitucional da liberdade de expressão e informação}

A imprensa no Brasil, por mais de três séculos, foi impedida por Portugal de estabelecer-se e, aos transgressores era imposta a pena de prisão, além do confisco de todo o material de trabalho. Foi D. João VI quem criou a imprensa régia, em maio de 1808 , devidamente acompanhada da censura prévia, e o primeiro jornal - Gazeta do Rio publicava apenas atos governamentais e notícias da família que, então, reinava no país. ${ }^{91}$

As ideias da Revolução Francesa fizeram-se sentir pelo mundo todo e no Brasil não foi diferente, influenciando o decreto de D. João VI, de 02 de março de 1821, que aboliu a censura prévia $^{92}$ e regulamentou a liberdade de imprensa.

Em 1821, pelo decreto de 09 de março foram estabelecidas as Bases da Constituição Política portuguesa, onde se fez constar, no artigo 8 , que "a livre comunicação dos pensamentos é um dos mais preciosos direitos do homem. Todo o cidadão pode, conseguintemente, sem dependência de censura prévia, manifestar suas opiniões em qualquer matéria, contanto que haja de responder pelo abuso de esta liberdade nos casos e na forma, que esta lei e jurados determinar".

A assembléia constituinte de 1823, reunida por D. Pedro após a proclamação da Independência do Brasil, propôs, no artigo 23, que "os escritos não estão sujeitos à

90 Segundo Hamilton Leal, "via de regra as Constituições, sendo como são uma conseq ência de transformações políticas, pacíficas ou violentas, não importa, estão sujeitas às influências doutrinárias dos matizes que compõem as correntes constituintes. Tais circunstâncias, aliadas à preocupação de rapidez no reestruturamento legal, acabam sempre por encontrar uma fórmula harmonizadora para o todo". Cf. História das Instituições Políticas do Brasil. Brasília: Ministério da Justiça, 1994, p. 413.

${ }^{91}$ LEITE FILHO, Solidônio. Comentários à lei de Imprensa. Rio de janeiro: J. Leite \& Cia, 1925, p. 15-17.

92 Esclarece Solidônio Leite Filho que "esse decreto não acabou de facto com a censura; mas apenas modificou o modo de fazê-la: em vez de recahir sobre os manuscriptos, passou a ser exercida nas provas impressas. Os impressores eram obrigados a remeter ao Director dos Estudos dous exemplares das provas que se tirassem de cada folha na imprensa, afim de que, ouvido o parecer do censor régio, ao qual fosse distribuído, sobre se continham alguma cousa contra a religião, a moral e bons costumes, contra a Constituição e pessoa do soberano, ou contra a tranqüilidade publica, se prosseguisse na impressão". Cf. Comentários...cit., p. 18. 
censura, nem antes nem depois de impressos; e ninguém é responsável pelo que tiver escrito ou publicado, salvo nos casos e pelo modo que a lei apontar". 93

Foi com a Constituição do Império ${ }^{94}$, de 1824 , que adveio entre nós a consagração do princípio da liberdade de imprensa, cujo artigo 179, IV, dispunha: “Todos podem comunicar os seus pensamentos por palavras, escritas e publicá-los pela imprensa, sem dependência de censura, contanto que hajam de responder pelos abusos que cometerem no exercício deste direito, nos casos e pela forma que a lei determinar".

A lei regulamentar, portanto, estaria adstrita às garantias essenciais da impossibilidade de se negar o direito de livre publicação, bem como de estipular regras que consistiam em censura prévia. Somente assim, segundo Pimenta Bueno, a imprensa pode ser "um instrumento poderoso, cujo uso e liberdade é característica dos povos e governos livres". 95

Em 15 de novembro de 1889 foi proclamada a República e, em 24 de fevereiro de 1891, foi promulgada a Constituição da República dos Estados Unidos do Brasil ${ }^{96}$, na qual foram contempladas inúmeras liberdades individuais, nelas incluída a liberdade de imprensa.

Constou da primeira Constituição Republicana, Carta que adotou princípios considerados liberais e democráticos, na Seção II, art. 72, § 12, que dispunha sobre

${ }^{93}$ A Assembléia Constituinte foi dissolvida em 12 de novembro de 1823, mas o projeto demonstrava a intenção de garantir, de maneira segura, a liberdade de imprensa. Cf. CAVALCANTI FILHO, Theóphilo. A liberdade de imprensa na formação constitucional brasileira. Revista dos Tribunais, v. 315, jan. 1962, p. 595.

${ }_{94}$ Octaciano Nogueira, analisando a Constituição de 1824, diz: "como primeiro texto de nossa história constitucional, não podemos nos esquecer de que ela é fruto da frustração da dissolução da Constituinte de 1823, que não apenas começou a gerar o divórcio entre a Coroa e a opinião pública, mas manchou de sangue o governo de D. Pedro I, com a reação pernambucana de 1824, vincando de forma indelével a vocação autoritária do Monarca. Muito embora outorgada, ela marcou o início da institucionalização da monarquia constitucional. E, a partir daí, instituiu os Poderes do estado, garantiu os direitos e conteve os abusos. A prática por ela instituída, no entanto, não se moldou senão com o tempo. Quando o Legislativo se instalou, em maio de 1826, quatro anos depois de proclamada a independência, é que, na verdade, teve início a prática constitucional. In: Constituições brasileiras. 1824. Brasília: Senado Federal, biênio 2003/2004, v.1. p. 17. Sobre a Constituição do Império ver, também, BARBALHO U. C., João. Constituição Federal Brazileira. Commentarios. Rio de Janeiro: Litho-Typographia, 1902.

${ }^{95}$ PIMENTA BUENO, José Antonio. Direito público brasileiro e análise da Constituição do império. Rio de Janeiro: Ministério da Justiça, 1958, p. 385.

${ }^{96}$ Sobre a Constituição Republicana de 1891, cf. BALEEIRO, Aliomar. Constituições brasileiras. 1891 Brasília: Senado Federal. Biênio 2003/2004. v. II. 
Declaração de Direitos: “Em qualquer assunto é livre a manifestação do pensamento pela imprensa, ou pela tribuna, sem dependência de censura, respondendo cada um pelos abusos que cometer nos casos e pela forma que a lei determinar. Não é permitido o anonimato".

Com texto semelhante ao da Constituição do Império, o art. 72, §12 diferencia-se desse, tão somente, quanto à impossibilidade da informação anônima. Com isto, pretendeuse que "a máxima liberdade de manifestação do pensamento correspondesse à consequente responsabilidade pelos abusos cometidos. E o único meio de tornar efetiva a responsabilidade era exigir a assinatura autoral, proibindo o anonimato"97. Manteve-se, ainda, a proibição da censura, como a mais absoluta garantia da liberdade de expressão do pensamento.

Mister ressaltar, também, que nos primeiros tempos da vigência desta Constituição, houve algumas tentativas de reprimir os excessos da imprensa, mas logo foi restabelecida a ampla liberdade do pensamento, como normatizada na presente Carta Republicana. ${ }^{98}$

A nova Carta de 1934, originária de duas revoluções, a de 1930 e a de 1932, ainda que de curta vigência, teve como ideias mestras "de um lado, o binômio da propaganda da Revolução de 30: justiça e a representação; de outro, a constitucionalização do País, cobrada por uma revolução derrotada pelas armas, mas cuja força espiritual iria marcar de forma indelével a política nacional". 99

De maneira mais detalhada, somente nesse aspecto diferenciando-se das demais Constituições, a Constituição de 34, no Capítulo II - "Dos direitos e garantias individuais"-, inciso I , fez constar: "Em qualquer assunto é livre a manifestação do

${ }^{97}$ LEITE FILHO, Solidônio. Comentários...cit. p. 28.

${ }^{98}$ MAXIMILIANO, Carlos. Comentários à Constituição Brasileira de 1891.Brasília: Senado Federal, 2005 , p. 709. Sobre o assunto, ver também: FERREIRA, Waldemar Martins. História do direito constitucional brasileiro. Brasília: Senado Federal, 2003.

${ }^{99}$ POLETTI, Ronaldo. Constituições brasileiras. 1934. Brasília: Senado Federal. Biênio 2003/2004, 2001 , v. III, p. 55. Diz o autor que a revolução de 30 tinha um "ideário liberal em política, embora os acontecimentos posteriores a transformassem num projeto social-democrático e, em seguida, na causa eficiente de uma ditadura bajuladora do fascismo europeu. Já o heroísmo paulista de 1932 pode ter tido causas econômicas não identificadas na época [...] ou motivos políticos sediados no regionalismo (a política do café-com-leite) desalojado do poder pela revolução vitoriosa, mas, inobstante isso, o movimento de São Paulo foi cunhado de revolução constitucionalista. [...] Imbuído de ideais pela Constituição, o povo paulista ergueu-se em armas e ofereceu o sangue de sua mocidade em holocausto à Pátria”. (p. 13-14). 
pensamento, sem dependência de censura, salvo quanto a espetáculos e diversões públicas, respondendo cada um pelos abusos que cometer, nos casos e pela forma que a lei determinar. Não é permitido o anonimato. É assegurado o direito de resposta. A publicação de livros e periódicos independe de licença do Poder Público. Não será, porém, tolerada propaganda de guerra ou de processos violentos para subverter a ordem política ou social”.

A Constituição de 34, não obstante sua importância histórica, sobretudo porque trazia no seu texto ideias consideradas "revolucionárias", foi "rasgada" pelo golpe de $37 .{ }^{100}$

Instaurado o regime ditatorial do Estado Novo. ${ }^{101}$ Getúlio Vargas promulgou a Carta Constitucional de 1937. Sob a ditadura, a Constituição de 37 foi a única na qual constou a possibilidade de instituição da censura, além de punir severamente os responsáveis por crimes de imprensa. ${ }^{102}$

Com a volta da democracia, nova Constituição foi promulgada em 18 de setembro de 1946.

${ }^{100}$ POLETTI, Ronaldo. Constituições brasileiras. 1934. vol. III. Brasília: Senado Federal. Biênio 2003/2004, 2001, p. 54. Sobre a Constituição de 34, ver PONTES DE MIRANDA, Francisco Cavalcanti. Comentários à Constituição da República dos Estados Unidos do Brasil. Rio de Janeiro: Guanabara, 1934.

${ }^{101}$ Segunda Constituição outorgada no Brasil, Francisco Campos, seu principal autor, quando rompeu com o ditador, disse em entrevista no Correio da Manhã, do Rio de Janeiro, que a Carta "era um documento que não podia 'invocar em seu favor o teste da experiência', pois não foi 'posta à prova', permanecendo 'em suspenso desde o dia de sua outorga",. E continuou: "de valor puramente histórico. Entrou para o imenso material que, tendo sido ou podendo ter sido jurídico, deixou de o ser ou não chegou a ser jurídico por não haver adquirido ou haver perdido sua vigência”. Cf. PORTO, Walter Costa. Constituições brasileiras. 1937. Brasília:Senado Federal, 2001, v. IV, p. 17-18.

${ }^{102}$ Art. 122, 15: "Todo cidadão tem o direito de manifestar seu pensamento, oralmente, por escrito, impresso ou por imagens, mediante as condições e nos limites prescritos em lei. A lei pode prescrever: a) com ofim de garantir a paz, a ordem e a segurança pública, a censura prévia da imprensa, do teatro, do cinematógrafo, da radiodifusão, facultando à autoridade competente proibir a circulação, a difusão ou a representação. b) medidas para impedir as manifestações contrárias à moralidade pública e aos bons costumes, assim como as especialmente destinadas à proteção da infância e da juventude; c) providências destinadas à proteção do interesse público, bem- estar do povo e segurança do Estado. A imprensa regular-se-á por lei especial, de acordo com os seguintes princípios: (...) e) a responsabilidade se tornará efetiva por pena de prisão contra o diretor responsável e pena pecuniária aplicada à empresa; f) as máquinas, caracteres e outros objetos tipográficos utilizados na impressão do jornal constituem garantia do pagamento da multa, reparação ou indenização, e das despesas com o processo nas condenações pronunciadas por delito de imprensa(...)". Segundo CRETELLA JR., Comentários à Constituição Brasileira de 1988. Rio de Janeiro: Forense Universitária, 1990, v. I, p. 27, "No período que vai de 1937 a 1945, o Brasil funcionou como se estivesse sem Constituição, sob o domínio do ditador". 
No que respeita à liberdade de imprensa, disse a Carta de 46 ser livre a manifestação do pensamento, admitindo a censura, tão somente, para espetáculos e diversões públicas e proibiu o anonimato. ${ }^{103}$

Essas Constituição durou por 20 anos e registrou um só estado de sítio, período em que não houve liberdade de imprensa. No mais, a livre manifestação de pensamento e expressão foi considerada "absoluta"104, e um dos direitos individuais de máxima importância, como deve ser nos regimes democráticos. ${ }^{105}$

Com a Revolução de 1964, institucionalizou-se o regime militar e, em 15 de março de 1967 entrou em vigor nova Constituição. De caráter extremamente conservador, a Carta constitucional também previu, no artigo $153, \S 8^{\circ}$, a liberdade de manifestação de pensamento, "bem como a prestação de informação independentemente de censura", sem tolerância, no entanto, "a propaganda de guerra, subversão da ordem ou de preconceitos de religião, de raça ou de classe, e as publicações e exteriorizações contrárias à moral e aos bons costumes".

Embora o texto da lei fosse semelhante ao das Constituições mais democráticas, o fato é que, na prática, ela não se efetivou na sua inteireza, exatamente por tratar-se de um período militar no qual prevaleceu não somente na Magna Carta, mas também na

103 Art. 141, § 5: É livre a manifestação do pensamento, sem que dependa de censura, salvo quanto a espetáculos e diversões públicas, respondendo cada um, nos casos e na forma que a lei preceituar, pelos abusos que cometer. Não é permitido o anonimato. É assegurado o direito de resposta. A publicação de livros e periódicos não dependerá de licença do Poder Público. Não será, porém, tolerada a propaganda de guerra, de processos violentos para subverter a ordem política e social, ou de preconceitos de raça ou de classe."

104 BALEEIRO, Aliomar. LIMA SOBRINHO, Barbosa. Constituições brasileiras. 1946. Brasília: Senado Federal, 2001, v. V, p. 24. Sobre a Constituição de 46, ver, também, DUARTE, José. A Constituição brasileira de 1946: exegese dos textos à luz dos trabalhos da Assembléia Constituinte. Rio de Janeiro, 1947, v. II; PONTES DE MIRANDA. Comentários à Constituição de 1946. (arts. 129-144). Rio de Janeiro: Boffoni, 1947, v. III.

${ }^{105}$ Ressalta Eduardo Espínola, Constituição dos Estados Unidos do Brasil (18 de setembro de 1946). São Paulo: Freitas Bastos, 1952, v. I, p. 52-53, que "os governos totalitários suprimem inteiramente a liberdade de manifestação do pensamento, tornando a imprensa dirigida ou estatizada". Mas, acrescenta o autor, "nas modernas Constituições democráticas, os direitos individuais são proclamados e garantidos enfaticamente, numa reação enérgica contra os postulados dos regimes totalitários. A Constituição é minuciosa, na especificação dos direitos individuais, estabelecendo ainda regras sobre os meios e processos de garantia, para que sejam eles eficientemente protegidos. [...] De modo geral, pode-se afirmar que, com maior desenvolvimento dos direitos fundamentais do homem e do cidadão constantes das Declarações de Direitos norte-americana, e francesa do fim do século XVIII foram aí reafirmados, como também procedeu a Assembléia Constituinte Francesa, na Constituição que o plebiscito acaba de rejeitar. A livre manifestação do pensamento, sem dependência de censura ou se trate da imprensa periódica, ou da publicação de livros, é um dos direitos individuais de capital importância no regime democrático". 
irradiação de seus princípios na sociedade, "o papel de preservar os fatores reais do poder ${ }^{106}$, situação não compatível com uma ampla liberdade de imprensa. ${ }^{107}$

Aliás, foi no período da ditadura militar que maior censura prévia se impôs aos jornalistas, havendo notícias de perseguições, processos e prisões à margem da legalidade, além de violências físicas e morais contra os profissionais da imprensa.

Nessa época, foi editada a Lei n. 5.250, de 09 de fevereiro de 1967, que regulou a liberdade de manifestação do pensamento e de informações, com inúmeras restrições, mas considerada "liberal" no momento político em que a prática era de cerceamento absoluto da liberdade assegurada na Constituição.

A denominada "Lei de Imprensa", no entanto, sob muitos aspectos não foi recepcionada pela Constituição Federal de 1988. Em 30 de abril de 2009, o Supremo Tribunal Federal, julgando a Arguição de Descumprimento de Preceito Fundamental n. 130, ajuizada pelo Partido Democrático Trabalhista e tendo por objeto a referida lei, concluiu ter sido ela integralmente revogada pela atual Carta Magna.

Finalmente, a Constituição de 1969 (Emenda Constitucional n. I, promulgada em 17 de outubro de 1969), manteve, em relação à liberdade de manifestação do pensamento, no artigo $153, \S 8^{\circ}$, praticamente o mesmo texto de 1967 , muito pouco alterando quanto ao conteúdo e à forma do dispositivo. O que se verifica, no entanto, é que as pouquíssimas

106 BRITO, Luiz Navarro de. A Constituição de 1967. In: CAVALCANTI, Themístocles Brandão; BRITO, Luiz Navarro de; BALEEIRO, Aliomar. Constituições brasileiras. 1967. Brasília: Senado Federal, 2001. p. 39. Esclarece o autor, ainda, que "na Constituição brasileira de 1967, esta consciência conservadora encontra-se perfeitamente delineada na distribuição e integração do poder entre vários grupos políticosterritoriais que enformam o Estado; em outras palavras, no sistema federativo vários mecanismos institucionais de controle garantem a composição politica existente. Mas, eles sobretudo revelam as contradições de uma sociedade em crise de desenvolvimento. De fato, a conformação e relações entre esferas de governo nacional, estaduais e municipais, ao tempo em que ratificam o condomínio de elites dominantes, também acasalam os reagentes internos ou exteriores a esse acordo". (A constituição... cit., p. 40).

${ }^{107}$ É necessário lembrar, conforme aduz Celso Bastos, que as grandes turbulências políticas e econômicas ocorridas entre 1967 a 1969, com movimentos estudantis, dos trabalhadores, que levaram às ruas denúncias sobre o que consideravam as mazelas do poder. Esses eventos se refletem na edição de um novo ato institucional de força, AI n. 5, de 13 de dezembro de 1968, que rompeu com a Constituição de 67 e "foi marcado por um autoritarismo ímpar do ponto de vista jurídico, conferindo ao Presidente da República uma quantidade de poderes de que muito provavelmente poucos déspotas na história desfrutaram”. Cf. BASTOS, Celso Ribeiro; MARTINS, Ives Gandra. Comentários à Constituição do Brasil. São Paulo: Saraiva, 1988, v. I. p. 322-323. 
alterações trataram as restrições das liberdades com maior subjetividade, ampliando o campo interpretativo das "publicações e exteriorizações contrárias à moral e aos bons costumes". 108

Da evolução constitucional exposta, no entanto, concernente à liberdade de imprensa, até a Carta que antecede a Constituição de 1988, nada foi expresso sobre o sigilo da fonte de informação jornalística, como instrumento garantidor da eficácia daquela.

\subsubsection{A positivação do sigilo na Constituição de 1988}

A luta pelo retorno da democracia havia começado com o golpe de 1964, principalmente após o AI5. Foram vários movimentos, em 1984, que culminaram com a participação popular pela eleição direta do Presidente da República. Esse seria o início da busca pela reestruturação política do país. Em 1986, foi convocada uma Assembleia Constituinte que produziria um texto constitucional moderno, inovador, situando o Brasil no novo tempo, adequado à necessária evolução política para um Estado Democrático. Assim, em 05 de outubro de 1988, foi promulgada a Constituição da República Federativa do Brasil.

Com esse espírito democrático que norteou a nova Carta constitucional, após anos de censura, a liberdade de informação ganhou contorno especial quando efetivado pelos jornalistas, profissionais dos meios de comunicação.

No capítulo dos "Direitos e Garantias Fundamentais" o legislador constituinte, ampliando a diretriz seguida nas Constituições anteriores, relativa aos direitos fundamentais, ao dispor sobre o acesso de todos à informação (inciso XIV), acrescentou, como novidade, pois até então não houve norma semelhante nas demais Cartas, que é "resguardado o sigilo da fonte quando necessário ao exercício profissional”.

\footnotetext{
${ }^{108}$ Dispôs o texto da Emenda 1 de 1969, no art. 153, 8 : "É livre a manifestação do pensamento, de conviç̧ão politica ou filosófica, bem como a prestação de informação independentemente de censura, salvo quanto a espetáculos e diversões públicas, respondendo cada um, nos termos da lei, pelos abusos que cometer. É assegurado o direito de resposta. A publicação de livros, jornais e periódicos independe de licença da autoridade. Não serão, porém, toleradas a propaganda de guerra, de subversão da ordem ou de preconceitos de religião, raça ou de classe, e as publicações e exteriorizações contrárias à moral e aos bons costumes".
} 
Como direito do jornalista, a proclamação constitucional da inviolabilidade do sigilo da fonte, quando necessário ao exercício profissional, visou a "garantir a toda a sociedade ampla e total divulgação dos fatos e notícias de interesse público, auxiliando, inclusive, a fiscalização da gestão da coisa pública e pretendendo evitar as arbitrariedades do Poder Público". 109

A liberdade de acesso à informação, no entanto, nas Cartas anteriores de cunho liberal, já estava compreendida na consagração da ampla liberdade de imprensa. Desta feita, veio ela explicitada, bem como acompanhada pelo instrumento garantidor de sua efetivação, que é o sigilo da fonte, dirigido aos profissionais - jornalistas - que atuam nos meios de comunicação. ${ }^{110}$

\subsubsection{Status jurídico-normativo do sigilo: direito e garantia}

A localização normativa confere ao sigilo o caráter de um direito fundamental? ${ }^{111}$

Para a doutrina, direito fundamental é um direito humano ${ }^{112}$ não somente reconhecido, mas também protegido pelo texto constitucional do Estado, portanto, positivado no âmbito nacional. Difere do direito humano, porque vem inserido em nível constitucional. $^{113}$

\footnotetext{
${ }^{109}$ MORAES, Alexandre de. Constituição do Brasil interpretada e legislação constitucional. 6 ed., São Paulo: Atlas, 2006, p. 255.

${ }^{110}$ FERREIRA FILHO, Manoel Gonçalves. Comentários à Constituição Brasileira de 1988. São Paulo: Saraiva, 1990, v. I, p. 39.

${ }^{111}$ Antonio Magalhães Gomes Filho responde afirmativamente à pergunta. Cf. Direito à prova no processo penal. São Paulo: RT, 1997, p. 130.

${ }_{112}$ Para Fábio Comparato, há um "aparente pleonasmo da expressão direitos humanos ou direitos do homem. Trata-se, afinal, de algo que é inerente à própria condição humana, sem ligação com particularidades determinadas de indivíduos ou grupos". Cf. A afirmação histórica dos direitos humanos. 7 ed. São Paulo: Saraiva, 2010, p. 70.

${ }^{113}$ Fábio Comparato esclarece que a distinção entre direitos humanos e direitos fundamentais, feita pela doutrina alemã, explica o reconhecimento da vigência efetiva desses direitos, seu caráter de obrigatoriedade no meio social. Assim, direitos fundamentais "são os direitos humanos reconhecidos como tais pelas autoridades às quais se atribui o poder político de editar normas, tanto no interior dos Estados quanto no plano internacional; são os direitos humanos positivados nas Constituições, nas leis, nos tratados internacionais". Cf. A afirmação...cit., p. 70-71.
} 
Por conseguinte, os direitos humanos vêm positivados no plano internacional e quando passam a integrar o rol de direitos fundamentais da Constituição (direito interno), assim se denominam. ${ }^{114}$

Essa conceituação formal ${ }^{115}$ de direitos fundamentais, em princípio, parece não explicar a ideia de que o sigilo da fonte seja um direito fundamental. É que, não obstante esteja ele inserido na Constituição brasileira, entre os "Direitos e Garantias Fundamentais", verificamos que nos tratados internacionais de direitos humanos não foi reconhecido expressamente, mas deriva da ampla liberdade de expressão e informação.

Assim, porque o direito em análise não foi positivado internacionalmente, a teoria doutrinária exposta, aparentemente, é insuficiente para justificar o sigilo como direito fundamental, que ora é tutelado na Carta Magna de 88.

Há, todavia, na expressão utilizada por Ingo Sarlet, uma "fundamentalidade em sentido material," 116 comum aos direitos humanos e direitos fundamentais constitucionais, que reconhece a proteção de certos valores e reivindicações essenciais a todos os seres humanos. $^{117}$

\footnotetext{
${ }^{114} \mathrm{Em}$ uma acepção restrita e normativa, Paulo Bonavides esclarece que "direitos fundamentais são aqueles direitos que o direito vigente qualifica como tais". Cf. BONAVIDES, Paulo. Curso de Direito Constitucional. 26 ed. atual. São Paulo: Malheiros, 2011, p. 560.

${ }^{115}$ Conforme preceitua Maurício Zanoide de Moraes, in: Presunção de inocência e processo penal brasileiro: análise de sua estrutura normativa para a elaboração legislativa e para a decisão judicial. Rio de Janeiro: Lumen Juris, 2010, p. 214, esse critério formal "está baseado na forma de positivação feita pelo constituinte (legislador fundamental) na Constituição. Assim, todos os enunciados normativos inseridos no capítulo dos direitos e garantias fundamentais (arts. 5 a 17, CR) são enunciados normativos de direitos e garantias fundamentais ou, dizendo de modo mais simples, disposições de direitos fundamentais".

116 SARLET, Ingo Wolfgang. A eficácia dos direitos fundamentais: uma teoria geral dos direitos fundamentais na perspectiva constitucional. 10 ed. rev.atual. Porto Alegre: Livraria do Advogado, 2009, p. 33. Sobre a fundamentalidade material, mencionamos aqui a didática explicação de BOBBIO, Norberto. $A$ era dos direitos. Trad. Carlos Nelson Coutinho. Rio de Janeiro: Elsevier, p. 499: "Significa que o conteúdo dos direitos fundamentais é decisivamente constitutivo das estruturas básicas do Estado e da sociedade. [...] Por um lado, a fundamentalização pode não estar associada à constituição escrita e à idéia de fundamentalidade formal como o demonstra a tradição inglesa das Common-Law Liberties. Por outro lado, só a idéia de fundamentalidade material pode fornecer suporte para: (1) a abertura da constituição a outros direitos, também fundamentais, mas não constitucionalizados, isto é, direitos materialmente mas não formalmente fundamentais ...".

${ }^{117}$ É bastante enfático, Jorge Miranda, quanto à existência do conceito material de direitos fundamentais. Diz ele que "não se trata de direitos declarados, estabelecidos, atribuídos pelo legislador constituinte, pura e simplesmente; trata-se também dos direitos resultantes da concepção de Constituição dominante, da ideia de Direito, do sentimento jurídico coletivo". Aliás, esclarece o autor que "a distinção de direitos fundamentais em sentido formal e direitos fundamentais em sentido material remonta ao IX Aditamento (de 1791) à Constituição dos Estados Unidos e encontra-se, expressa ou implícita, em não poucas Constituições. Na verdade, lê-se nesse Aditamento que a especificação de certos direitos pela Constituição não significa que
} 
Explica o autor que sob essa ótica é preciso "atentar para o fato de que não existe uma identidade necessária entre o elenco dos direitos fundamentais e direitos humanos reconhecidos - nem entre o direito constitucional dos diversos Estados e o direito internacional - e isso pelo fato de que, algumas vezes, o catálogo de direitos fundamentais constitucionais fica aquém dos direitos humanos contemplados nos documentos internacionais e, outras vezes, chega a ficar - ressalvadas algumas exceções - bem além, como é o caso da nossa atual Constituição."118

Então, como direito, o sigilo do jornalista é protegido pelo sistema normativo constitucional, devendo ser respeitado, devendo ser fundamental, vale dizer, intocável na existência autônoma que é seu núcleo essencial. ${ }^{119}$ Isso porque, o que o torna fundamental é um valor social de extrema importância que ele reflete. ${ }^{120}$

Portanto, as aspirações e ideais de uma imprensa livre, com a ampla possibilidade de informar e se informar, instrumentalizada pela possibilidade de não revelar as origens do conhecimento objeto de divulgação pela mídia, de retórica num discurso político de direitos humanos passaram a existir como direitos fundamentais.

Desse reconhecimento, é necessário, no entanto, que derive a efetivação do sigilo da fonte. Se já houve proteção jurídica desse direito, se já foi ele fundamentado, imprescindível garanti-lo ${ }^{121}$ na sua essência, realizando-o para o fim proposto.

fiquem excluídos ou desprezados outros direitos até agora possuídos pelo povo. [...] Quer isto dizer que há (ou pode haver) normas de Direito ordinário, interno e internacional, atributivas de direitos equiparados aos constantes de normas constitucionais". Cf. Manual de Direito Constitucional: direitos fundamentais. 4 ed., Coimbra: Coimbra Ed., 2008, t. IV, p. 12-13.

118 SARLET, Ingo Wolfgang. A eficácia...cit., p. 33. Para André Ramos Tavares, Curso de direito constitucional. 5 ed. rev. atual. São Paulo: Saraiva, 2007, p. 433-437, defende a conceituação material dos direitos fundamentais.

${ }^{119}$ Segundo Ingo Sarlet, "a garantia de proteção do núcleo essencial dos direitos fundamentais aponta para a parcela do conteúdo de um direito sem o qual ele perde sua mínima eficácia, deixando, com isso, de ser reconhecível como um direito fundamental. Com efeito, a limitação de um direito fundamental não pode privá-lo de um mínimo de eficácia. A idéia fundamental desse requisito é a de que existem conteúdos invioláveis dos direitos fundamentais que se reconduzem a posições mínimas indisponíveis às intervenções dos poderes estatais, mas que também podem ser opostas - inclusive diretamente - a particulares [...]. Mesmo quando o legislador está constitucionalmente autorizado a editar normas restritivas, ele permanece vinculado à salvaguarda do núcleo essencial dos direitos restringidos”. Cf. A eficácia...cit., p. 402.

${ }^{120}$ FERREIRA FILHO, Manoel Gonçalves. Princípios fundamentais de direito constitucional. 2 ed. São Paulo: Saraiva, 2010, p. 98-99.

121 Disse Norberto Bobbio sobre a questão das garantias dos direitos do homem: "Entende-se que a exigência do respeito aos direitos humanos e às liberdades fundamentais nasce da convicção, partilhada universalmente, de que eles possuem fundamento: o problema do fundamento é ineludível. Mas, quando digo 
Como direito fundamental, gera para seus titulares a possibilidade de impor seus interesses perante órgãos estatais, os quais, nas suas diversas esferas - administrativa, legislativa e judicial, obrigam-se à realização daquele direito. É a conhecida concepção dos direitos fundamentais, como direitos de defesa de posições subjetivas contra a intervenção do Poder Público. ${ }^{122}$

Esse "direito de defesa" contra o Estado não implica, porém, que o direito fundamental ao sigilo seja absoluto, pois não se concebe que assim se caracterize. Aliás, como lembra Manoel Gonçalves Ferreira Filho ${ }^{123}$, a ideia já havia sido insculpida no art. $4^{\circ}$ da Declaração de Direitos de 1789, nos seguintes termos: "o exercício dos direitos naturais de cada homem não tem por limite, senão os que asseguram aos outros membros da sociedade o gozo destes mesmos direitos". Portanto, ainda que de maneira comedida, o limite ao direito fundamental é sempre possível.

É possível extrairmos desse "direito de defesa" do indivíduo contra o Estado a afirmação de que o sigilo da fonte também é uma garantia. Na lição trazida por Ruy Barbosa, as garantias constitucionais são "defesas aos direitos especiais dos indivíduos"124.

Assim, na expressão "é resguardado o sigilo da fonte" (art. 5 , IV), garante-se um direito reconhecido. Logo, se o jornalista tem o direito de impor seus interesses contra os órgãos do Estado, cabe a esse garantir a não exigência da revelação da fonte pelo profissional da mídia.

Trata-se de uma garantia de direito fundamental, denominada na doutrina de "garantia constitucional especial", que é uma norma constitucional destinada a conferir ao titular do direito fundamental um instrumento para exigir a concretização de seu interesse. $^{125}$

que o problema mais urgente que temos de enfrentar não é o problema do fundamento, mas o das garantias, quero dizer que consideramos o problema do fundamento não como inexistente, mas como - em certo sentido - resolvido, ou seja, como um problema com cuja solução já não devemos mais nos preocupar”. Cf. $A$ era dos direitos. cit. p.25-26.

${ }^{122} \mathrm{Cf}$. MENDES, Gilmar Ferreira. Os direitos fundamentais e seus múltiplos significados na ordem constitucional. Revista Eletrônica de Direito do Estado, n. 23, julho-setembro 2010, p. 2. Disponível em: http://www.direitodoestado.com.br. Acesso 20 jul. 2011.

${ }_{123}$ Cf. Principios...cit., p. 95.

${ }^{124}$ Cf. Comentários à Constituição Federal Brasileira. São Paulo: Saraiva, 1934, v. VI. p. 278.

${ }^{125}$ SILVA, José Afonso da. Curso...cit., p. 189. 
Sob essa ótica, o sigilo de não revelação da fonte é garantia, instrumento para a realização do direito à liberdade de imprensa.

Concluindo, o dispositivo constitucional em exame prescreve um direito fundamental ao sigilo da fonte, que é garantia instrumental para o exercício do trabalho jornalístico bem como para realização da ampla liberdade de informação a qual, por sua vez, também é um direito humano fundamental e garantia de um Estado Democrático. Portanto, vê-se que direitos e garantias se fundem no mesmo enunciado normativo e, tão só teoricamente é possível vislumbrar a diferenciação dos conceitos.

\subsubsection{Sigilo e sua estrutura normativa de regra}

Não poderemos prescindir nessa investigação, que tem como ponto de partida um direito positivado na Constituição Federal, do estudo sobre a estrutura normativa do sigilo da fonte jornalística. O objetivo, após sinteticamente descrever a estrutura, é verificar como a norma se efetiva, como deve ela ser aplicada ao caso concreto, mais especificamente, nas questões relacionadas aos atos do processo penal.

A moderna doutrina constitucional vem debatendo, com rigorismo técnico, a diferença entre princípios e regras ${ }^{126}$, normas que compõem o texto da Carta Magna.

O que distingue essas normas é a estrutura dos direitos que elas garantem. ${ }^{127}$ Basicamente, para a "teoria dos princípios" as normas ${ }^{128}$ encontradas nos textos constitucionais podem ter o nível de princípio ou o nível de regras.

${ }^{126}$ Foi R. Dworkin quem propôs a distinção entre princípios e regras, causando relevante impacto no estudo dos direitos fundamentais. Cf. CANOTILHO, J.J. Gomes. Estudos...cit., p. 158.

${ }^{127}$ SILVA, Virgílio Afonso. Direitos fundamentais: conteúdo essencial, restrições e eficácia. $2^{\mathrm{a}}$ ed., São Paulo: Malheiros, 2010, p. 45.

${ }^{128}$ Segundo Humberto Ávila, “normas não são textos nem o conjunto deles, mas os sentidos construídos a partir da interpretação sistemática de textos normativos. Daí se afirmar que os dispositivos se constituem no objeto da interpretação; e as normas no seu resultado. O importante é que não existe correspondência entre norma e dispositivo, no sentido de que sempre que houver um dispositivo haverá uma norma, ou sempre que houver uma norma deverá haver um dispositivo que lhe sirva de suporte". Cf. Teoria dos princípios: da definição à aplicação dos princípios jurídicos. 12ª ed. atual. Rio de Janeiro:Malheiros, 2011,p. 30. 
Há uma ideia comum entre os doutrinadores de que "princípios seriam as normas mais fundamentais do sistema, enquanto que as regras costumam ser definidas como uma concretização desses princípios e teriam, por isso, caráter mais instrumental e menos fundamental"129. Com efeito, as regras são mais descritivas, prescrevem condutas e garantem direitos de forma definitiva, enquanto os princípios são genéricos, abrangentes, descrevem valores e contém mandamentos "prima facie".

Os argumentos de Dworkin e Robert Alexy sobre a diferenciação proposta são trazidos pela doutrina nacional como base do estudo das normas da Constituição brasileira. $^{130}$

Para o primeiro, as regras devem ser aplicadas na sua inteireza se tiverem o pressuposto de validade e, sem esse, não podem ser aplicadas. Para Alexy, o critério, também, não é diferente. Portanto, o grau de realização da regra não pode variar, uma vez que expressam direitos e deveres definitivos, o que, por consequência, deve realizar aquilo que, e exatamente como prescreve. a utilização da forma conhecida como "tudo ou nada".

Quanto aos princípios, Dworkin fala que o critério de validade deve ser afastado. Pela abrangência da norma, deve ser utilizado o seu "peso" como decisivo, suficiente para poder prevalecer no caso concreto. Alexy, por sua vez, fala que princípios são "mandamentos de otimização", ou seja, utiliza um critério de intensidade que determina sua realização, em diversos graus, a cada caso concreto, sempre na maior medida possível.

O princípio, se aplicado na sua totalidade, possivelmente invadirá a área de abrangência de outro ou outros princípios. As regras, ao contrário, não se submetem às condições fático-jurídicas para sua aplicação e como "mandamentos definitivos”, ou se

129 SILVA, Virgílio Afonso da. Princípios e regras: mitos e equívocos acerca de uma distinção. Revista Latino-Americana de Estudos Constitucionais 1 (2003): 607-630, p. 611.

${ }^{130}$ SILVA, Virgílio Afonso da. Princípios e regras...cit. pp. 609-611. ÁVILA, Humberto. Teoria...cit. GRAU, Eros Roberto. Ensaio e discurso sobre a interpretação/aplicação do direito. 5 ed., rev. atual. São Paulo: Malheiros, 2009, p. 173-185. 
aplicam integralmente por meio de subsunção ou não se aplicam ${ }^{131}$, cumpre-se, ou não, o que elas impõem.

Da diferença estrutural decorre que a forma de aplicação das normas-princípios é o sopesamento e a aplicação das normas-regras, a subsunção. ${ }^{132}$ Portanto, em caso de conflito entre princípios, é possível ponderar, harmonizar os valores que eles emanam e daí, um prevalece sobre o outro; as regras, ao contrário, quanto à aplicabilidade, não admitem o critério do "peso", mas realizam-se inteiramente, ou não, sob o critério da validade.

Necessário observar, ainda, que as regras não são elaboradas para resolver determinadas situações concretas, mas são previstas para solucionar casos abstratamente previstos pelo legislador. Daí a razão de certo nível de abrangência na sua definição normativa, gerando, por conseguinte, a necessidade de interpretação de seu texto para amoldar-se à situação específica quando de sua aplicabilidade. ${ }^{133}$

Verificamos que o legislador constituinte de 88 , ao inserir entre os direitos fundamentais o resguardo do sigilo da fonte para o exercício do trabalho profissional do jornalista, assim o fez por meio de uma regra que visa a concretizar, assegurar e garantir o princípio da liberdade de expressão e informação.

O sigilo da fonte, primeiramente, é uma norma-regra prescritiva de uma conduta que permite ao destinatário - profissional da mídia, não identificar a origem da sua informação para fins de trabalho.

Como regra, deve ser aplicada diretamente, quando ocorrer a subsunção ao caso concreto, assim como se dá na análise da configuração do tipo penal, na qual se determina se os fatos que ocorreram são adequados, ou não, à norma penal, caracterizando crime.

131 ALEXY, Robert. Teoria dos direitos fundamentais. Trad. Virgílio Afonso da Silva, 2 ed., São Paulo: Malheiros, 2011, item 3.2.1, p. 94 e sgts.

${ }^{132}$ SILVA, Virgílio Afonso da. Direitos .... cit. p. 47.

${ }^{133}$ MORAES, Maurício Zanoide de. Presunção de inocência...cit. p. 272. 
Porque o conteúdo da regra está inserido dentro de certo grau de generalidade, não autoriza a ponderação, o sopesamento. Todavia, o significado de seu texto normativo poderá ser interpretado ${ }^{134}$.

Observa-se que o próprio legislador constituinte já atribuiu ao intérprete (legislador infraconstitucional, juiz), a possibilidade de interpretação do texto normativo, ao dizer que o sigilo da fonte é resguardado quando necessário ao trabalho.

Concluímos, do exposto, que o sigilo da fonte é norma de direito fundamental com estrutura de regra; deve ser aplicada quando ocorrer a subsunção ao caso concreto ${ }^{135}$, valendo definitivamente aquilo que ela prescreve, pois transporta "disciplina suficientemente densa para assegurar a aplicabilidade imediata"136; não admite sopesamento de interesses, se em conflito com outras normas, e seu texto é passível de interpretação.

\footnotetext{
${ }^{134}$ Sobre a interpretação dos preceitos constitucionais, cf. ANDRADE, José Carlos Vieira de. Os direitos fundamentais na Constituição portuguesa de 1976. Coimbra: Almedina, 1987, p. 115-141; BARROSO, Luís Roberto. Interpretação e aplicação da Constituição. 2 ed., São Paulo: Saraiva, 1998.

${ }^{135}$ Bastante significativa e merece ser transcrita a lição de Virgílio Afonso da Silva sobre o significado de "caso concreto": "pode significar, na forma como pode ser compreendida também em sua acepção não técnica, a decisão de um caso específico por parte do Judiciário (o exemplo mais usual é a colisão entre a liberdade de imprensa e o direito à privacidade, honra ou imagem); mas caso concreto pode também significar algo menos concreto, ou, pelo menos, mais distante daquilo que usualmente se costuma entender por isso, já que aponta, nessa segunda acepção, a uma decisão do legislador acerca da colisão entre direitos fundamentais. Uma tal decisão legislativa, se, por um lado, é mais abstrata que uma decisão judicial, não deixa de ter também sua dimensão concreta, já que o legislador não se preocupa, nesses casos, com a importância geral e abstrata de dois direitos fundamentais, mas sua importância relativa, em uma situação hipotética. ... ". Cf. Direitos fundamentais...cit., p. 140.

${ }^{136}$ CANOTILHO, José Joaquim Gomes. Estudos sobre direitos fundamentais. 2 ed., Coimbra: Coimbra Ed., 2008, p. 155.
} 


\section{SEGREDO PROFISSIONAL DO JORNALISTA NO DIREITO CONSTITUCIONAL ESTRANGEIRO: FONTES NORMATIVAS E JURISPRUDÊNCIA}

A constitucionalização do sigilo da fonte de informação jornalística, em diversos países, é fruto do reconhecimento da liberdade de imprensa como necessária ao desenvolvimento das sociedades democráticas. São poucos os países cujas Constituições o asseguram expressamente. Em alguns, a sua proteção é considerada decorrente e como instrumento de eficácia da ampla liberdade de expressão e informação. Outros países, no entanto, o negam.

Cabe-nos aqui, fazermos referências ao segredo profissional dos jornalistas nas Constituições de alguns países. O tratamento do tema nas leis infraconstitucionais, nos códigos deontológicos e na jurisprudência, será feito em capítulo próprio e dirigindo-se a análise à luz da prova no processo penal.

\subsection{Espanha}

Na Constituição espanhola de 1978, o segredo da fonte é um direito fundamental expressamente previsto no artigo 20, 1, d: "Se reconhecem e pretegem os direitos: d) A comunicar ou receber livremente informação veraz por qualquer meio de difusão. A lei regulará o direito à cláusula de consciência e ao segredo profissional no exercício destas liberdades".

Até o momento da Carta de 78, esse direito não havia sido incorporado na Espanha, com hierarquia constitucional. Foi, então, normatizado como um autêntico direito fundamental de proteção das fontes e da informação, destinado a garantir aos profissionais dos meios de comunicação o efetivo exercício da função em um "Estado social $e$ democrático de Direito ${ }^{, 137}$, como se constitui a Espanha. ${ }^{138}$ Então, o direito a não revelar a

${ }^{137}$ Artigo $1^{\circ}$ da Constituição Espanhola. 
fonte, assim inserido no artigo 20, é destinado aos jornalistas e visa a proteger o direito à informação.

Primeiramente, releva anotar que o segredo, como normatizado pelo legislador constituinte, é um direito que integra outro direito, fundamental: "a comunicar informação veraz, por parte daqueles que convertem essa informação em sua profissão habitual"139. Portanto, não é um dever jurídico, o que possibilita ao jornalista invocá-lo, ou não, podendo dele dispor como melhor entender, frente a qualquer autoridade, inclusive judicial. ${ }^{140}$

Em segundo lugar, o bem jurídico protegido é o anonimato sobre a identidade da fonte para que o direito à informação seja assegurado de maneira integral. Para tanto, no artigo 20,1,d da Constituição espanhola, o legislador estabeleceu que a divulgação da notícia, como interesse público, deve prevalecer sobre a identidade do informante.

Como instrumento de garantia da opinião pública livre, imprescindível numa sociedade pluralística, Carrillo assinala que a Constituição espanhola, ao outorgar superior valor a esse direito reconhecido ao jornalista, baseou-se na "concepção integral do direito à informação como fator que define o Estado democrático". ${ }^{141}$ Portanto, trata-se o segredo da fonte de um direito fundamental, não somente por estar inserido no "Título primeiro: Dos direitos e deveres fundamentais", mas porque possui caráter substantivo intimamente vinculado a um direito fundamental como é o direito à informação e também à liberdade de expressão. $^{142}$

Por conseguinte, é o interesse público da informação que justifica o direito de os jornalistas não divulgarem suas fontes. ainda, esse direito, "instrumental a serviço da

\footnotetext{
${ }^{138}$ Conforme a Exposição de Motivos da proposta de Lei Orgânica reguladora da cláusula do segredo profissional dos jornalistas, apresentada em 1993, à Mesa do Congresso na Espanha, "A força normativa da Constituição dotou este direito de plena eficácia jurídica desde sua promulgação e, em consequência, sua exigibilidade jurídica vincula poderes públicos e particulares." Cf. La clausula de conciencia y el secreto profesional de los periodistas. Madrid: Centro de Estudios Constitucionales, 1994, p. 119.

${ }_{139}$ CARRILLO, Marc. Cláusula de consciencia y secreto profesional de los comunicadores. CARPIZO, Jorge; CARBONELL, Miguel (Coords.). Derecho a La información y derechos humanos. Estudios em homenaje al maestro Mario de La Cueva. México: Universidad Nacional Autónoma de México, 2000, p. 426.

${ }^{140}$ É a opinião do doutrinador espanhol Marc Carrilo, in: Clausula de consciencia...cit., p. 426.

${ }^{141}$ CARRILLO, Marc. La clausula....cit. p. 46.

${ }^{142}$ CARRILLO, Marc. La clausula....cit. p. 46.
} 
liberdade de expressão e uma garantia institucional do direito a livre informação, na medida em que introduz mecanismos que facilitam o acesso a âmbitos da esfera pública ou privada de difícil permeabilidade". ${ }^{143}$

Finalmente, justificando a opção do legislador constituinte, em proteger a liberdade de informação pública com o sigilo da fonte, tem-se que, a própria Constituição estabeleceu a diferença entre o segredo jornalístico e os demais segredos profissionais, distinguindo-se, por consequência, os bens jurídicos protegidos. Com efeito, no artigo 24, 2, a Constituição da Espanha, ao instituir os direitos processuais constitucionais, como o Juiz natural, a ampla defesa, o processo público com todas as suas garantias, a utilização dos meios de provas pertinentes, a presunção de inocência, fez constar que "a lei regulará os casos em que, por razão de parentesco ou de segredo profissional, não se estará obrigado a declarar sobre fatos presumivelmente delitivos"144, protegendo aqui, a intimidade e a privacidade das pessoas.

\subsection{Segue: Portugal}

A Constituição da República Portuguesa, de 1976, previu na Parte I (Direitos e deveres fundamentais) no Título II, (Direitos, liberdades e garantias), artigo 38, 2, b, “o direito dos jornalistas, nos termos da lei, ao acesso às fontes de informação e à protecção da independência e do sigilo profissionais (...)". ${ }^{145}$

\footnotetext{
143 Jurisprudência do Tribunal Constitucional da Espanha (STS de 21 de janeiro de 1994, Ponente Eduardo Fernández-Cid de Temes), citado por Adrian Ventura, Libertad...cit., p. 147.

${ }^{144} \mathrm{Na}$ íntegra, o artigo 24 da Constituição espanhola: "1. Todas as pessoas têm direito a obter a tutela efetiva dos juizes e tribunais no exercício de seus direitos e interesses legítimos, sem que, em nenhum caso, permaneça indefeso. 2. Assim mesmo, todos têm direito ao Juiz natural predeterminado pela lei, à defesa e à assistência de um advogado, a serem informados da acusação formulada contra eles, a um processo público sem dilações indevidas e com todas as garantias, a utilizar os meios de prova pertinentes para sua defesa, a não declarar contra si mesmo, a não confessar-se culpável e à presunção de inocência. A lei regulará os casos em que, por razão de parentesco ou de segredo profissional, não se estará obrigado a declarar sobre fatos presumivelmente delitivos".

145 “Artigo $38^{\circ}$ (Liberdade de imprensa e meios de comunicação social). 1. É garantida a liberdade de imprensa. 2. A liberdade de imprensa implica: a) A liberdade de expressão e criação dos jornalistas e colaboradores, bem como a intervenção dos primeiros na orientação editorial dos respectivos órgãos de comunicação social, salvo quando tiverem natureza doutrinária ou confessional; b) $O$ direitos dos jornalistas, nos termos da lei, ao acesso às fontes de informação e à protecção da independência e do sigilo profissionais, bem como o direito de elegerem conselhos de redação; $O$ direito de fundação de jornais e de quaisquer outras publicações, independentemente de autorização administrativa, caução ou habilitação prévias. (...)". Sobre todas as reformas constitucionais em Portugal, ver CANOTILHO, J.J.Gomes e
} 
Direito fundamental do jornalista, essencial à liberdade de imprensa, a Constituição portuguesa tutela o sigilo da fonte de informação no artigo referente à "liberdade de imprensa e meios de comunicação social", no qual esses são garantidos e possuem, como elemento de realização, o segredo profissional. O legislador constituinte vincula a liberdade de imprensa ao direito do sigilo, nos seguintes termos: "A liberdade de imprensa implica: [...] a proteção do sigilo" (artigo 38, 2, b). Portanto, aquela liberdade assegurada no Estado de Direito Democrático envolve, depende e justifica a necessidade de proteger as fontes de informação, onde serão colhidos os dados que comporão as notícias divulgadas pela imprensa.

No entanto, na doutrina e jurisprudência portuguesas a questão do segredo profissional do jornalista vem sendo debatida, e é palco de grandes discussões quanto ao seu alcance, sobretudo em virtude da revisão do Código de Processo Penal ocorrida em 1998, cujo artigo 135 deu ao sigilo da fonte igual tratamento dispensado aos demais segredos profissionais, como aos dos advogados, dos médicos e ministros religiosos. ${ }^{146}$

Assim, a polêmica surge na prática dos tribunais, ao preponderar a ideia de que, por tratar-se de um direito, o segredo profissional do jornalista não é absoluto e, nos termos da lei, pode ser levantado pelas autoridades judiciárias. ${ }^{147}$ Quando do desenvolvimento da relação entre sigilo profissional e a prova penal, procuraremos demonstrar como a questão vem sendo tratada em Portugal.

MOREIRA, Vital. (Organizadores). Constituição da República Portuguesa. Lei do Tribunal Constitucional. 5 ed. rev. Coimbra: Coimbra Ed., 1998.

${ }^{146}$ Artigo 135 do Código de Processo Penal: "1. Os ministros de religião ou confissão religiosa e os advogados, médicos, jornalistas, membros de instituições de crédito e demais pessoas a quem a lei permitir ou impuser que guardem segredo podem escusar-se a depor sobre os factos por ele abrangidos. 2. Havendo dúvidas fundadas sobre a legitimidade da escusa, a autoridade judiciária perante a qual o incidente se tiver suscitado procede às averiguações necessárias. Se, após estas, concluir pela ilegitimidade da escusa, ordena, ou requer ao tribunal que ordene, a prestação do depoimento. (...)".

147 "A protecção do segredo profissional do jornalista refere-se às fontes de informação do jornalista, incluindo os arquivos jornalísticos de texto, som ou imagem das empresas ou quaisquer documentos susceptíveis de as revelar, mas não inclui todo o material de investigação utilizado pelo jornalista na sua actividade profissional. Este regime não é uma agressão desproporcionada ao segredo profissional garantido aos jornalistas, nos termos do acórdão do TC n. 7/87, dados os valores em favor dos quais o segredo profissional dos jornalistas é sacrificado e as cautelas de que se faz rodear a quebra do segredo ". Cf. AlbuQuerque, Paulo Pinto de. Comentário do Código de Processo Penal à luz da Constituição da República e da Convenção Europeia dos Direitos do Homem. 3 ed. actual. Lisboa: Universidade Católica Ed., 2009, item 24, p. 368. 


\subsection{Segue: Suécia}

Entre os países que possuem a regulamentação constitucional do segredo profissional do jornalista, vale mencionar a Suécia, que além da tradição na liberdade de imprensa, parece ter sido precursora, no mundo, ao legislar sobre a liberdade de expressão. $^{148}$

Nesse país escandinavo, a liberdade de expressão e informação, nas vertentes de procurar, comunicar, expressar ideias, opiniões e sentimentos e receber informação, é um direito fundamental garantido a todo cidadão em suas relações com as instituições públicas, cuja proteção encontra-se em quatro textos que integram a Constituição sueca: o Instrumento de Governo, a Lei de Sucessão, a Lei de Liberdade de Imprensa (1766) ${ }^{149}$ e a Lei Fundamental de Liberdade de Expressão, incorporada em 1992. ${ }^{150}$

Com esse teor democrático, o legislador não poderia ter deixado de lado a regulamentação do segredo jornalístico. Embora não tenha sido assim referido, concebeuse que o sujeito informante tem o dever ao anonimato o qual, se violado, é punido com prisão e multa. Reconhece-se, por conseguinte, que “[...]nenhum autor, de qualquer impresso, estará obrigado a que nela apareça seu nome, psudônimo ou sobrenome". ${ }^{151}$

Importante assinalar que todo cidadão, para exercer o direito à informação, pode ter acesso aos documentos públicos, bem como divulgá-los aos profissionais dos meios de comunicação. Esse mesmo direito alcança os funcionários públicos, os quais não podem sofrer qualquer repressão por parte do Estado. ${ }^{152}$ A única restrição às fontes são a defesa nacional e o que possa colocar em risco a integridade e a privacidade das pessoas.

\footnotetext{
${ }^{148}$ Cf. Adrian Ventura. Libertad...cit., p. 123.

149 A Lei de Liberdade de Imprensa de 1766, sofreu várias modificações nos anos de 1772, 1810, 1812, 1949 e 1982, até a sanção da lei Fundamental da Liberdade de Expressão, incorporada em 1992. Cf. VENTURA, Adrian. Libertad...cit., p. 123.

150 ainda Adrian Ventura que fala da importância da liberdade de imprensa na Suécia: "prova da importância que a Constituição da Suécia dá à liberdade de imprensa é que no momento de aderir à União Européia, fez emenda no Capítulo 10, artigo 5 do instrumento de Governo, o qual, com sua nova redação, permite ao Parlamento sueco transferir a favor dos órgãos da EU competências judiciais, mas exclui expressamente dessa transferência algumas questões precisas", entre elas as restrições aos direitos e liberdades reconhecidas no Capítulo 2. Portanto, a Suécia não admite a competência judicial européia com relação a assuntos vinculados com liberdade de expressão e informação. Cf, Libertad...cit., p. 125.

${ }^{151}$ Lei de Liberdade de Imprensa, Capítulo e, 16.

${ }^{152}$ CARRILLO, Marc. Clausula de conciencia...,cit., p. 428.
} 
Sustentando a afirmação, mencionamos o caso JO 1983/1984 s. 473, no qual o Ombudsman do Parlamento, instado, disse que uma agente do serviço público de saúde, tem direito a comunicar livremente informação à mídia, pois integra o princípio da ampla publicidade. Referia-se a uma situação na qual a agente de saúde falou à imprensa sobre a má assistência prestada a um paciente, quando estava em pauta a questão que envolvia cortes no sistema de saúde. Afirmou o ombudsman que somente em casos especificados em leis de imprensa ou na Lei de Segredo de Estado, existe o dever de guardar a reserva. ${ }^{153}$

Em outro caso, JO 2000/2001 s. 555 de 2000, o Ombudsman Parlamentário disse que “[...] o Governo, quando protege a liberdade de expressão, provê uma salvaguarda contra o Estado, garantia que significa que nenhuma autoridade pública pode agir, formal ou informalmente, contra qualquer funcionário que tenha exercido o direito constitucional de opinar e expressar-se, inclusive se deu informação errônea. A autoridade só poderá corrigir essa informação, se foi errônea, repassando informação mais exata, mas não pode punir o funcionário." 154

O segredo da fonte, nas leis que integram a Constituição da Suécia ${ }^{155}$ é muito amplo, inclusive quanto à proteção, mas admite limites expressamente previstos em lei e em casos excepcionais. Sobre esse aspecto, prevê o Artigo $3^{\circ}$ do Capítulo 3 da Lei de Imprensa: “[...] O dever de confidencialidade segundo o parágrafo um, não se aplica: 1) se a pessoa em cujo favor opera o dever de confidencialidade deu seu consentimento para a revelação da sua identidade; [...] 4) se um tribunal o considera necessário, quando a questão concerne a um delito [...] para que a informação seja proporcionada durante os procedimentos legais, assim como se uma pessoa acusada ou uma pessoa suspeita de delito menor, comunicou informação ou contribuiu para o assunto; ou 5) se um tribunal, em qualquer caso, encontra, em atenção ao interesse público e privado, que é de particular importância para a informação assim como para a identidade dá-la em testemunho sob juramento [...] o tribunal assegurará que não sejam questionadas

${ }^{153}$ VENTURA, Adrian. Libertad...cit., p. 129-130.

${ }^{154}$ VENTURA, Adrian, Libertad...cit., p. 130.

155 A Constituição da Suécia não se encontra em um documento único, mas em quatro textos legislativos nos quais se integram as leis fundamentais. Para um estudo aprofundado sobre a liberdade de imprensa na Suécia, ver OLIVEIRA, João Gualberto. Liberdade de Imprensa no Brasil e na Suécia. São Paulo: Sociedade Brasileira de Expansão Comercial, 1956. 
situações que possam invadir o dever de confidencialidade, além do admissível em cada caso particular”.

A mencionada lei também não autoriza busca e apreensões pela polícia, para encontrar informações, violando o dever de confidencialidade. Aliás, se há enquadramento nos casos excepcionais mencionados, para a investigação de crime, é necessária autorização judicial $\left(\operatorname{artigo} 4^{\circ}\right)$.

Portanto, ainda que de maneira superficial, pudemos constatar o detalhamento da Constituição sueca, na questão relacionada à liberdade de expressão e informação, revelando, pelo teor de sua proteção, o grau de democracia no país.

\subsection{Segue: Alemanha}

A Lei Fundamental da República Federal da Alemanha, de 1949 não prevê o sigilo da fonte. A liberdade de imprensa e de informação foi reconhecida na Lei Federal de 25 de julho de 1975, no artigo 53, 1, 5: “Aquelas pessoas que se dediquem, ou se tenham dedicado profissionalmente à preparação, confecção ou difusão de produtos impressos jornalísticos ou de emissões radiofônicas, também têm direito a negar-se a declarar acerca da pessoa do editor, remetente ou responsável por colaborações ou documentações, assim como sobre as informações que os haja proporcionado em atenção a sua atividade, sempre que se trate de colaborações, documentação ou informações destinadas à parte redacional". E o artigo 97, 2, 3, reza: "Sempre que se dê o direito a negar declarações em virtude do artigo 53,1,5, às pessoas ali mencionadas, será ilegal o seqüestro de escritos, documentos gráficos, sonoros ou de dados, cópias ou outras reproduções que se encontrem sob a custódia destas pessoas ou da Redação editorial, imprensa ou emissora radiofônica."

A proteção legal mencionada decorre do artigo 5, par.1 da Constituição Alemã de 1949, da liberdade de expressão e informação, bem como a liberdade dos meios de 
comunicação ${ }^{156}$ : "Todos têm direito a expressar e difundir livremente a própria opinião oralmente, por escrito e com recurso a imagens, e a informar-se sem maior impedimento a partir de fontes de geral acesso. Se garante a liberdade de imprensa e a liberdade de informar através do rádio, televisão e cinema. Não se exercerá censura alguma".

Portanto, é à luz do $\S 5$ da Grundgesetz, como emanação do princípio da liberdade de imprensa, que tem sido defendido o direito de os jornalistas não revelarem suas fontes.

\subsection{Segue: Itália}

$\mathrm{Na}$ Itália, a disciplina jurídica do segredo jornalístico encontra sua formulação no artigo 200, 3, do Código de Processo Penal ${ }^{157}$, que decorre da liberdade de manifestação do pensamento em todas as suas formas. O artigo 21 da Constituição da República Italiana delineia essa liberdade com função de "pilar do edifício democrático surgido sobre as ruínas do fascismo" "158: "Todos têm direito de manifestar livremente o próprio pensamento com a palavra, o escrito e qualquer outro meio de difusão. A imprensa não pode estar sujeita à autorização ou censura". ${ }^{159}$

\footnotetext{
${ }^{156}$ Segundo Kurt Madlener, a liberdade dos meios de comunicação garantida pelo artigo 5, par. 1, inciso 2 da Grundgesetz (Constituição Alemã de 1949; GG), "é ampla e não se refere unicamente ao conteúdo intelectual do produto jornalístico, mas abarca também os pressupostos materiais indispensáveis para que este produto possa ser elaborado e posto em circulação; por isso, o artigo 5 garante também o livre estabelecimento de empresas jornalísticas, o livre acesso a profissão de jornalista, a compra de maquinário e papel, a difusão do produto, por exemplo o envio por correio etc. Por conseguinte, seria incompatível com a liberdade de imprensa definida no artigo $5 \mathrm{GG}$, se se exigisse, por exemplo, um diploma para poder trabalhar como jornalista [...]". Cf. El ejercicio legítimo del deber de información del periodista, como causa de justificación en el proceso penal por injurias y difamación. In: Justicia Penal y Libertad de Prensa, Ilanud, San José, Octde 1993, t. I, p. 217. Disponível em: http//www.ilanud.or.cr/centro-de-documentacion/bibliotecadigital/176-justicia-penal-y-libertad-de-prensa.html. Acesso em: 20 de jul. 2011.

${ }^{157}$ Artigo 200. Segredo profissional. 1. Não podem ser obrigados a depor sobre quanto conheceram por razões do próprio ministério, oficio ou profissão, salvo os casos nos quais são obrigados a referi-los à autoridade judiciária: [...] 3. As disposições previstas nos parágrafos 1 e 2 se aplicam aos jornalistas profissionais, relativamente aos nomes das pessoas das quais os mesmos tiveram notícias em caráter de confiança, no exercício da sua profissão. Todavia, se as notícias são indispensáveis para fins da prova do crime, para qual se procede a sua veracidade pode ser acertada somente através da identificação da fonte da notícia, o juiz ordena ao jornalista a indicar a fonte das suas informações". In: Codice de Procedura Penale e le altre nuove norme del processo penale. Milano: Giuffrè, 1995, p. 170. (tradução livre).

${ }^{158}$ MUSCO, Enzo. Justicia Penal y Libertad de prensa. Informe sobre Italia. In: Justicia Penal y Libertad de Prensa, Tomo I, Ilanud, San José, Octubre de 1993, p.587. http//www.ilanud.or.cr/centro-dedocumentacion/biblioteca-digital/176-justicia-penal-y-libertad-de-prensa.html. Acesso em: 17 ago. de 2011.

${ }^{159}$ In:FINOCCHIARO, Alfio e Mario. Costituzione della Repubblica Italiana e leggi sulla Corte Costituzionale. $2^{\mathrm{a}}$ ed.,Rimini: Maggioli, 1995.
} 
Nesse país, o reconhecimento do poder-dever do jornalista de opor o segredo, em sede processual passava, necessariamente, pelo balanceamento de valores opostos, ou seja, a liberdade de manifestação do pensamento de um lado e, de outro, a administração da justiça com a consequente exigência de uma verdade a ela submetida.

A solução dada pelo artigo 200, 3, do Código de Processo Penal, expressa a dificuldade geral do balanceamento dos interesses opostos e, neste novo quadro normativo, o legislador possibilitou ao juiz, para fins de prova no processo penal, ordenar, ao jornalista, a revelação da fonte.

A escolha legislativa, por conseguinte, privilegiou a exigência de uma correta aplicação da justiça e faz concluir que, na Itália, a liberdade de expressão e informação, de onde decorre o segredo da fonte jornalística, não é, em abstrato, superior ao valor fundamental da justiça. ${ }^{160}$ "À luz do critério normativo delineado, o legislador tutelou com o silêncio sobre as fontes, a liberdade de imprensa, na sua expressão mais ampla da liberdade de manifestação do pensamento, constitucionalmente garantida, e tentou resolver exigências que se contrapõem, como a punição dos crimes de um lado e o interesse público à informação, de outro". 161

O artigo 21 da Constituição italiana prevê, também, sequestro do material da imprensa, no caso de delitos e somente por ato motivado da autoridade judiciária. Este parágrafo $3^{\circ}$, segundo decisão da Corte Constitucional, "refere-se ao material impresso no qual se manifesta o pensamento humano [...]. O fim da citada norma constitucional é aquele de evitar que haja intervenções cautelares administrativas ou judiciais, não dirigidas a reprimir delitos expressamente previstos, impeçam ou obstacularizem a livre circulação das publicações, consideradas pela mesma norma como meio precípuo para a difusão do pensamento manifestado e para o exercício da atividade de informação". ${ }^{162}$

160 DI RONZO, Agnese. Il segreto del giornalista nel processo penale. Il diritto dell'informazione $e$ dell'informatica. Milano: Giuffrè, Anno XX, n. 6, dicembre 2004, p. 852.

${ }^{161}$ DI RONZO, Agnese. Il segreto...cit., p. 854.

162 Decisão da Corte Constitucional Italiana, de 12 de abril de 1973, n. 38. In: FINOCCHIARIO, Mario. Costituzione.....cit, p. 21. 


\subsection{Segue: França}

Bastante restritivo e com dificuldade de ser aceito, na França o segredo do jornalista não é assegurado na Constituição e, tampouco, na lei de imprensa. Aliás, Roland Dumas chega a afirmar que os direitos da personalidade e a paz social poderiam ser violados se os jornalistas tivessem imunidade quanto à necessidade de revelar a fonte o que “converteria a informação em algo incontrolável”. ${ }^{163}$

Os jornalistas são obrigados a revelar as fontes de informações. ${ }^{164}$ Em dezembro de 2010, o repórter francês Guillaume Dasquié teve revistada sua casa em busca de dados que permitissem identificar as fontes de um artigo publicado no Le Monde, no qual afirmou que a inteligência gaulesa soube de planos da Al Qaeda para sequestrar aviões. Interrogado durante horas sobre o artigo, bem como as fontes de documentos relativos ao assassinato de um magistrado francês - Bernard Borrel, no Djibuti -, recusou a indicar o nome do informante. Acusado por "comprometer a segurança nacional", foi condenado à pena de cinco anos de reclusão e mais 75 mil euros. ${ }^{165}$

No entanto, a proteção do sigilo, é uma reivindicação das organizações profissionais dos jornalistas que proclamam a "indignidade dos jornalistas" que devem, perante a justiça, revelar o nome de seus informantes.

Também a doutrina francesa vem respaldando o reclamo dos profissionais, sustentando que a liberdade de um jornal depende da liberdade das suas fontes de informação ${ }^{166}$, sobretudo porque o sigilo jornalístico decorre do direito à informação, que é

\footnotetext{
${ }^{163}$ DUMAS, Roland. Le droit de l'information. Paris: Presses universitaire de France, 1981, p. 184.

164 Nos casos conhecidos como "Paris Match"- publicação de fotos de um cadáver, conseguidas em um escritório de investigação policial - e "Canard Enchaine"- publicação de formulários de transferências de valores, da França para a Suiça, para um parlamentar - os jornalistas tiveram apreendidos seus materiais de trabalho. Cf. OLVERA, Salvador Ochoa. Las fuentes del periodista. Secreto profesional? México:Montealto, 2005, p. 169.

${ }^{165}$ Disponível em: http://www.jornalistas.eu/imprimir.asp?id=6223\&edcanal=496. Acesso em 21 jul. 2011.

166 LAMBERT, Pierre. Secret Professionnel. Bruxelles: Brylant, 2005, p. 339. Na mesma obra, o autor relaciona dois casos centenários da Corte francesa os quais denegaram aos jornalistas o direito de invocar o segredo da fonte quando chamados a testemunhar perante a justiça "(cass., 7 nov. 1855, Pas., 1855, I, p. 424, et le rapport du conseiller VAN HOEGAERDEN et cass., 25 avril 1870, Pas., 1870, I, p. 226) . A Corte superior de justiça de Luxemburgo, em 21 de março de 1957, considerou igualmente que o jornalista não está investido de funções que se permita considerá-lo como depositário de segredos de outros, em razão da profissão (Journ. Trib., 1957 et Ver. Dr. pén., 1956-1957, p.999)”, p. 338.
} 
um dos direitos do homem o qual, às vezes, deve prevalecer sobre a necessidade da repressão das infrações.

Os tribunais franceses apresentam-se severos e resistentes ao direito de os jornalistas manterem o anonimato das fontes de informação, não obstante a Lei de 4 de janeiro de 1993 ter reconhecido o sigilo daqueles profissionais, introduzindo no Código de Processo Penal que "todo jornalista ouvido como testemunha em relação a informações recebidas no exercício de sua atividade, é livre para não revelar sua origem". ${ }^{167}$

Em 09 de março de 2004, foi aprovada na França a Lei "Perben II" que trouxe várias alterações ao Código de Processo Penal, entre elas a obrigação de qualquer pessoa entregar documentos que tenha em sua posse, com a finalidade de instruir uma investigação criminal. A norma, no entanto, excepciona os jornalistas que devem consentir na entrega dos documentos que possuam, se forem eles exigidos ${ }^{168}$.

A regra processual penal francesa traduz, então, o alcance do direito ao segredo jornalístico: além da possibilidade de não testemunhar perante a Justiça, também manter sigilosos os documentos consistentes no material de trabalho. ${ }^{169}$ Tal interpretação, porém, não tem o condão de evitar que seja feita busca e apreensão dos documentos, como se deu no caso do repórter Dasquié.

\subsection{Segue: Inglaterra}

Em 1980, no caso Britsh Steel v. Granada Television, a Câmara dos Lordes inglesa decidiu, com voto contrário do Lord Salmon, que a empresa Granada não tinha direito privilegiado a manter anônima a identidade das pessoas que lhe forneceram informações e documentos confidenciais da British Steel, a fim de que essa pudesse tomar medidas judiciais contra seus empregados.

${ }^{167}$ Art. 109.2 do Código de Processo Penal. Cf. BROTÓNS, Iñigo Lazcano. El secreto profesional en el periodismo: Estudios sobre um derecho fundamental. Bilbao: Lete, 2007, p. 143.

${ }_{168}$ Cf. DANET, M. Jean (President).. Code de Procédure Pénale. Articles modifiés par la loi no 2004-204 du 9 mars 2004. Le nouveau procès pénal aprés la loi Perben II. Paris: Dalloz, 2004, p. 10.

${ }^{169}$ BROTÓNS, Iñigo Lazcano. El secreto...cit., p. 149. 
A decisão é consentânea com a relação extremamente repressiva entre Poder Judiciário e mídia, no direito inglês, onde o bom funcionamento da Justiça deve prevalecer sobre as questões relacionadas aos meios de comunicação. ${ }^{170}$

Com a aprovação do Contempt of Court $A c t^{171}$, em 27 de julho de $1981^{172}$, que visava a regulamentar a atuação da mídia na relação com o processo penal, estabeleceu-se na seção 10 que “Nenhum Tribunal pode requerer a uma pessoa a revelar, nem esta é culpável de desacato por negar-se a revelar, a fonte da informação contida em uma publicação pela qual é responsável, se não restar estabelecido pelo Tribunal que tal revelação é necessária aos interesses da justiça, da segurança nacional, ou a prevenção da desordem ou do crime". ${ }^{173}$

A jurisprudência inglesa, no entanto, que vinha mantendo o posicionamento de não aceitação do segredo da fonte, quando diante de outros interesses legítimos como a Justiça penal, apesar do amparo legislativo, ainda permanece afastando o direito dos jornalistas, interpretando com amplitude as exceções previstas na seção 10 do Contempt of Court Act.

Em 1984, posteriormente ao Contempt of Court Act, no caso Secretary of State for Defense v. Guardian Newspaper Ltd., um documento secreto do Governo inglês foi enviado ao jornal The Guardian, porém, a Corte dos Lordes determinou sua devolução, justificada pelo interesse da segurança nacional. ${ }^{174}$

Assim, a ordem judicial de revelação do segredo jornalístico - disclosure - tem-se tornado o posicionamento preponderante na Inglaterra. Isso porque, o direito tradicional

${ }^{170}$ DELMAS-MARTY, Mireille (Coord.) Procedure penali d'Europa. In: CHIAVARIO, Mario (Coord. da edição italiana). Padova:Cedam, 1998, p. 617-618.

${ }^{171}$ Esclarece Cunha Rodrigues que o contempt of court surge da ideia da necessidade de respeitar a Justiça e, portanto, abrange procedimentos que possam, de alguma maneira, interferir no modo de administrá-la. Assim, "o contempt of court compreende hipóteses diversas, desde represálias contra testemunhas, ao ultraje ao tribunal [...] à desobediência aos despachos do tribunal ou a qualquer conduta, intencional ou não adequada a provocar ingerência no curso da justiça por ocasião de um processo determinado". Cf. Justiça e comunicação social: mediação e interacção. Revista Portuguesa de Ciência Criminal. Coimbra, ano 7, fasc. 4, p. 531-576, out-dez. 1997, p. 553, nota 39.

${ }^{172}$ A reforma do Contempt of Court Act, em 1981 decorreu da necessidade do ordenamento jurídico britânico adequar-se às normas da Convenção Europeia dos Direitos Humanos, pois deveria cumprir obrigação internacional assumida, como país ratificador da Convenção. Cf. RODRÍGUEZ BAHAMONDE, Rosa. El secreto del sumario y la libertad de información en el proceso penal. Madrid:Dykinson, 1999, p. 93.

${ }^{173}$ Tradução livre do texto em inglês disponível em: http://www.legislation.gov.uk/ukpga/1981/49. Acesso em: 27 jul. 2011.

${ }^{174}$ OLVERA, Salvador Ochoa. Las fuentes... cit. p. 169. 
inglês não reconhecia a liberdade de expressão como direito fundamental e, tão somente, como um princípio da common law. ${ }^{175}$

Em 1998, com o reconhecimento da Convenção Europeia dos Direitos Humanos pelo ordenamento jurídico inglês, através do Human Rigths Act, as decisões judiciais dos tribunais ingleses mencionavam a nova fonte normativa, porém, ponderando a compatibilidade, ou não, com o interesse público no caso concreto.

Em dois casos - Ashworth Hospital Authority (junho de 2002) e Interbrew v. The Financial Times, The Guardian, The Times y The Independent, a Câmara dos Lordes entendeu que as ordens para a identificação das fontes era compatível com o artigo 10 da CEDH e com o Contempt of Court Act de 1981. ${ }^{176}$

\subsection{Segue: Estados Unidos da América}

Valor de extrema relevância no direito norte-americano, e com característica de imprescindibilidade para a democracia, a liberdade de expressão é proclamada na Primeira Emenda Constitucional ${ }^{177}$, de 1979 a qual estabelece que o cerceamento da liberdade da palavra ou de imprensa, não pode ser legislado pelo Congresso: “É vedado ao Congresso estabelecer qualquer religião de Estado ou proibir o livre exercício de qualquer culto $e$ restringir a liberdade de palavra e de imprensa, o direito dos cidadãos de se reunirem pacificamente e o de apresentarem petições ao Governo para a reparação de injustiças".

E, é na interpretação da Primeira Emenda que a liberdade de imprensa nos Estados Unidos da América vem sendo reconhecida na jurisprudência, com bastante amplitude, embasando com os precedentes das sentenças judiciais o sistema da common law, do "direito comum".

\footnotetext{
175 BRÓTONS, Iñigo, Lazcano. El secreto...cit., p. 50. Informa o autor que, no caso Granada, o anonimato das fontes restou mantido em virtude de forte pressão dos meios de comunicação e a própria empresa British Sttel desistiu de prosseguir sua investigações sobre a identidade dos informantes. (p. 50-51).

176 BRÓTONS, Iñigo Lazcano. El secreto...cit. p. 158-159.

177 Sobre a Primeira Emenda, ver FARBER, Daniel A. The first amendment. 2. ed. New York: The Foundation Press, 2003.
} 
No entanto, nem a Constituição, nem lei federal protegem o segredo da fonte. Não obstante, a legislação de vários Estados prevê a existência de shield law (leis escudo ou leis de proteção), embora com diferentes alcances nas suas interpretações sobre o significado de informação não confidencial, limites, ações nas quais podem ser alegados o sigilo, quem pode ser considerado jornalista etc. ${ }^{178}$

A primeira "lei escudo" foi aprovada em Maryland, no ano de 1896, tendo sido única até que, após três décadas, New Jersey adotou uma similar. Hoje, quarenta e nove Estados reconhecem o sigilo como privilégio dos jornalistas, por meio de diversas fontes, não apenas legais, mas por força da common $\operatorname{law}^{179}$.

Algumas leis dão aos jornalistas apenas um limitado privilégio diante da obrigação de testemunhar, outras, como as do Alabama e da Pensilvânia dão um alcance absoluto ao direito-privilégio, não só à fonte, mas também em relação à própria informação. Nesses Estados, os profissionais que trabalham para um meio de comunicação, sequer podem ser testemunhas. ${ }^{180}$

Todavia, quando se trata proteger o segredo profissional dos jornalistas, a questão não se coloca com tranqüilidade na jurisprudência americana. Na maioria dos Estados, a legislação e a justiça não admitem o privilégio do segredo como absoluto e as decisões judiciais são muito casuísticas, dependendo cada caso de um balanceamento de interesses: a necessidade de prova de um lado e, de outro, o interesse da imprensa de manter a confidencialidade da fonte. ${ }^{181}$

As soluções judiciais ${ }^{182}$ nos EUA mostram uma tendência atual de não reconhecer o segredo jornalístico, fundado na VI Emenda da Constituição, a qual estabeleceu: "Em

\footnotetext{
178 LAZCANO BROTÓNS, Iñigo. El secreto professional en el periodismo: estudios sobre um derecho fundamental. Bilbao: Lete, 2007, p. 165. Segundo o autor, no ano de 2005 foram apresentadas diversas propostas perante o Congresso e Senado dos EEUU sobre a criação de uma shield law federal, para proteger de maneira uniforme os jornalistas de todas as jurisdições e em todos os Estados. Porém, até o momento não houve aprovação de quaisquer dos projetos. Cf. El secreto...cit., p 166.

${ }^{179}$ Estudo abrangente e completo do sistema da common law, ver: SOARES, Guido Fernando Silva. Common law: introdução ao direito dos EUA. São Paulo: RT, 1999.

${ }^{180}$ VENTURA, Adrian. La libertad...cit., p. 180, nota 49.

${ }^{181}$ VENTURA, Adrian, La libertad...cit., p. 181.

182 Sobre as decisões da Corte americana, inclusive em relação à liberdade de imprensa, entre outros, relevante o texto de Luis Roberto Barroso: “A americanização do direito constitucional e seus paradoxos:
} 
todos os processos criminais o acusado terá direito a julgamento rápido e público, por um júri imparcial do Estado e distrito onde o crime tiver sido cometido, o qual distrito deverá ser previamente determinado por lei, e de ser informado da natureza e da causa da acusação, de ser confrontado com as testemunhas de acusação; de poder fazer comparecerem compulsoriamente as testemunhas a seu favor, e ter a assistência de advogados para a sua defesa".

Destacamos na Sexta Emenda, relevante para o tema, a existência de uma garantia do direito à produção probatória pelo acusado por prática de crime, o que implica a possibilidade de ouvir o jornalista sobre sua fonte de informação, acerca do fato objeto de litígio, argumento que fundamenta as decisões da Suprema Corte Americana, ao reconhecer o direito a um processo justo, o qual se macularia diante da negativa do profissional da mídia de não declarar.

Por outro lado, utilizando-se como argumento a Primeira Emenda, como mencionamos, que assegura uma ampla liberdade de imprensa, sem qualquer limite, encontram-se decisões judiciais as quais entendem que essa liberdade não pode ser maculada pelo direito de o Estado punir o crime.

Outras decisões baseadas na mesma Primeira Emenda, no entanto, discutem se é possível inferir da ampla liberdade de expressão e informação, o direito de os jornalistas não divulgarem as fontes.

A partir do caso Branzburg versus Hayes, ${ }^{183}$ de 1972, começou-se a discutir na doutrina constitucional americana a obrigatoriedade, ou não, da revelação da fonte da informação do jornalista. A Corte decidiu, por cinco votos a quatro, que os jornalistas, assim como os demais cidadãos, deveriam testemunhar perante o grande júri, revelando a

teoria e jurisprudência constitucional do mundo contemporâneo". Disponível em: http://www.luis robertobarroso.com.br/wp. Acesso em 22 de julho de 2011.

${ }^{183}$ Decisão 408 U.S.665 (1972). Branzburg foi um repórter de Kentucky que escreveu artigos descrevendo suas observações sobre a fabricação, haxixe e outras violações à lei de drogas, por dois jovens. Recusou-se, diante do grand jury, a identificar os indivíduos que mencionara no artigo. 
identidade de suas fontes, pois não existe um direito fundamental na Primeira Emenda, ao segredo que se pretendia resguardar. ${ }^{184}$

Dos votos dissidentes, um dos argumentos foi sobre o reconhecimento do absoluto segredo de não revelar a fonte, garantido na Primeira Emenda, pois a liberdade de imprensa sempre tem prioridade sobre a aplicação da lei. ${ }^{185} \mathrm{Em}$ outro voto, também dissidente, o Juiz Stewart, aplicou balance test, sustentando, sobretudo, que haveria necessidade de se comprovar que as informações trazidas pelos jornalistas não poderiam ser obtidas por meio diverso, menos ofensivo à Primeira Emenda. ${ }^{186}$

O argumento do balanceamento de valores, a partir de Branzburg, foi o que prevaleceu como aplicação interpretativa de várias decisões posteriores acerca da possibilidade, ou não, de se compelir um jornalista a divulgar a fonte em juízo. ${ }^{187}$

A importância do tema ficou evidenciada a partir do Caso Matthew Cooper e Judith Miller, jornalistas do New York Times e da revista Time, respectivamente, processados por recusarem-se a fornecer a identidade da agente secreta da CIA Valerie Plame. ${ }^{188} \mathrm{~A}$

${ }^{184}$ Decidiu a Corte: “ ... não encontramos base para sustentar que o interesse público na executoriedade da lei e na garantia de procedimentos efetivos do grande júri é insuficiente para sobrepujar o ônus resultante, mas incerto, sobre a coleta de notícias que se afirma ser consequência da insistência para que os repórteres, como quaisquer cidadãos, respondam às relevantes questões que lhes são apresentadas no decurso de uma investigação válida por um grande júri ou um julgamento penal ... ”. Cf. KENWORTHY, Bill. Branzburg v. Hayes, reporters’privilege \& circuit courts. Disponível em http://www.firstamedmentcenter.org/analysis.aspx?id=15525. Acesso em: 20 de jul. 2011.

${ }^{185}$ Disse o Juiz Douglas: "agora que as barreiras da lei e a tradição que protegeu a imprensa estão derrubadas, o povo é a vítima. A Primeira Emenda foi desenhada, precisamente, para prevenir essa tragédia". In: Branzburg, at 725, citado por Adrian Ventura, op. cit, p. 190.

${ }^{186}$ Branzburg v. Hayes, 408 U.S. 665 (1972).

${ }^{187}$ Outros casos relevantes nos EUA, nos quais foram invocados o segredo da fonte abrangido pela Primeida Emenda, merecem ser citados: In re Pappas, trata-se de um repórter - Paul Pappas - que permaneceu no quartel-general dos chamados Panteras Negras, sob a condição de não revelar nada do que visse ou ouvisse. Chamado a testemunhas perante o grande júri, recusou-se a dizer o nome das pessoas que integravam aquele partido, sustentando o segredo na primeira Emenda, o que foi confirmado pela Suprema Corte do Estado de Massachusetts; Caso Myron Farber, redator do New York Times que teve a prisão decretada em New Jersey, porque não quis revelar suas fontes informativas. Posteriormente, em grau de recurso, o repórter teve reconhecido seu direito à confidencialidade da fonte. Outros inúmeros casos envolvendo a identificação das fontes pelos jornalistas estão registrados em: http://www.firstamendmentcenter.org/analysis.aspx?id=15634. Acesso em 18.mar.2011.

${ }^{188} \mathrm{O}$ caso refere-se à publicação da notícia de que Valerie Plame, esposa do ex-embaixador Joseph Wilson, era agente da CIA. O Departamento de Justiça instaurou uma investigação para apurar eventual cometimento de delito por aqueles que revelaram a identidade da agente, pois tal conduta pode caracterizar crime, segundo a Ata de Proteção de Identidade de Agentes de Inteligência, de 1982. No curso das investigações, vários jornalistas foram intimados a depor e a revelar as fontes. Cooper disse que havia sido liberado da confidencialidade e forneceu a identidade do funcionário que passou a informação sobre Valerie Plame. Judith Miller, no entanto, recusou-se à revelação do nome, foi condenada por desacato ao Tribunal e 
condenação dos jornalistas foi justificada pelo apropriado equilíbrio entre a liberdade de imprensa e a necessidade da correta aplicação da Justiça.

\subsection{Segue: Argentina}

Como uma garantia que tem relação direta com a liberdade de expressão, a reforma constitucional argentina de 1994 incorporou no texto da Constituição Nacional, em seu artigo 43, parágrafo terceiro, o segredo das fontes de informação jornalística ${ }^{189}$ : “(...) Toda pessoa poderá interpor esta ação para tomar conhecimento dos dados a ela referidos e de sua finalidade, que constem em registros ou bancos de dados públicos, ou os privados destinados a prover informes, e em caso de falsidade ou discriminação, para exigir a supressão, retificação, confidencialidade ou atualização daqueles. Não poderá afetar-se o segredo das fontes de informação jornalística". 190

Muito embora a garantia ao segredo da fonte venha expressa no parágrafo dedicado ao habeas data, entenderam os legisladores constituintes que se vincula ele a um tema muito mais amplo e de grande importância que é a liberdade de imprensa. Segundo Adrian Ventura, no debate legislativo os constituintes chegaram à conclusão que a nova figura do

cumpriu pena de 18 meses de reclusão. Cf. OLVERA, Salvador Ochoa. Las fuentes del periodista: secreto profesional? México: Montealto, 2005, p.271-272. Considerando a relevância do caso que foi a raiz do intenso debate sobre o sigilo das fontes, travado nos EUA entre 2004 e 2005, transcrevemos, aqui, sua origem: O governo americano teria sido informado de que o "Iraque dispunha de armas de destruição massiva. Um diplomata (o embaixador Joseph Wilson) foi enviado à Nigéria pelo executivo estadudinense com o fim de verificar se esse país havia vendido urânio ao Iraque, o que havia servido para provar, ou pelo menos para fundamentar minimamente, a acusação de existência de armas de destruição massiva. $\mathrm{O}$ informe do embaixador foi negativo, entendendo que se tratava de uma pista falsa, porém o presidente Bush incluiu a afirmação de que Sadam Hussein havia tentado trazer quantidades significativas de urânio da África, em várias declarações públicas anteriores à guerra [...]. Meses depois, o citado diplomata publicou um artigo no The New York Times denunciando a situação, afirmando que o governo não havia levado em conta sua informação [...]. Dias após, vários jornalistas publicaram que a mulher do embaixador (Valerie Plame) era uma agente da CIA. A afirmação resultava grave [...] sobretudo porque esta revelação constitui nos EUA um delito federal punível com uma sanção penal que pode alcançar dez anos de prisão, segundo a Intelligence Identities Protection Act de 1982 (\$421). [...] A idéia das notícias sobre Plame era deixar claro que o embaixador não era especialista no assunto que havia informado e que, aproveitando-se das influências da situação pessoal de sua mulher, recebeu o encargo político mencionado." Cf. BROTÓNS, Iñigo Lazcano. El secreto professional en el periodismo. Bilbao: Baleuko, 2007, p. 166-167.

${ }^{189}$ Segundo Miguel Angel Ekmekdjian, a incorporação do segredo das fontes de informação na Constituição Nacional argentina foi a "reforma mais positiva", pois é preferível a impunidade de um delito, em alguns casos, se a prova do seu cometimento depender da fonte jornalística, ao levantamento desta, correndo o risco o profissional de perder sua fonte, que poderá retrair-se. In: Tratado de Derecho Constitucional, Buenos Aires: Depalma, 1997, t. IV, p. 95.

190 Disponível em http//www.senado.gov.ar/web/interes/constitucion/capitulo2.php. Acesso em 05 maio 2011. 
habeas data não poderia colocar em risco os arquivos jornalísticos e a identidade dos informantes dos meios de comunicação. Para tanto, criou-se uma barreira expressa contra agressões à imprensa, com cláusula que transcende o objeto da norma. ${ }^{191}$

Instalou-se um intenso debate doutrinário sobre ser, ou não, absoluta a cláusula sobre o segredo da fonte. Tem prevalecido a ideia de que não se trata de um direito absoluto e se há o embate de valores legítimos, deve-se pautar pela razoabilidade e ponderação entre eles. ${ }^{192}$

A jurisprudência argentina reconhece o direito ao sigilo da fonte e, assim como a Suprema Corte Americana, propõe um balanceamento de interesses case by case. No Caso Gorriarán Merlo, considerado o mais emblemático, os jornalistas invocaram a cláusula do artigo 43 da Constituição Nacional para não colaborar com a Justiça, e a Câmara Federal de Apelação, embora sustentando a relatividade do direito invocado, utilizando o critério da ponderação de interesses, resguardou a garantia constitucional de não revelação das fontes de informação. Disse que o direito ao segredo jornalístico é relativo e deve ceder diante de um interesse público de relevante hierarquia. Mas "iniciar uma investigação judicial sacrificando a garantia do artigo 43 da Constituição Nacional, sem antes esgotar outras vias independentes para comprovar a existência atual do grupo guerrilheiro, não resulta neste caso, aconselhável". ${ }^{193}$

Na mesma linha de ponderação de valores, outras decisões judiciais ${ }^{194}$ asseguraram aos jornalistas o pleno direito garantido no artigo 43 da Constituição Nacional.

${ }^{191}$ VENTURA, Adrian. Libertad...cit., p. 412.

192 Cf. DE LUCA, Javier Augusto. El secreto...cit.; SAGÜES, Néstor. Elementos de derecho constitucinal. Tomo II, Buenos Aires: Astrea, 1999. BADENI, Gregorio. Libertad de prensa. op. cit.

${ }^{193}$ Cámara Federal de Apelaciones de San Martín, Sala I, Secretaría Penal n. 3, causa 332/96. Trata-se de caso no qual foi divulgado em um programa televisivo que Gorriarán Merlo seria o cabeça no processo que se seguiu ao ataque do Movimiento todos por la Patria . Todos os envolvidos já haviam sido condenados por diversos delitos. Os jornalistas que fizeram a matéria foram convocados pelo juiz de Morón, onde tramitava a causa, para prestar testemunhos sobre os detalhes dos contatos que estabeleceram para chegar até o líder rebelde com o fim de determinar a existência de uma organização, bem como individualizar os possíveis participantes da atividade exercida por Gorriarán. Negaram-se a comparecer em juízo, invocando o artigo 43 da Constituição. Cf. DE LUCA, Javier Augusto. El secreto....cit., p. 99.

${ }^{194}$ Sobre os Casos Raña, Moschini, Catán v.p.t. Adrian Ventura. La libertad...cit., p. 430-437. 


\subsection{Consagração jurisprudencial do sigilo da fonte no Tribunal Europeu dos Direitos} Humanos

Como verificamos ${ }^{195}$, a Convenção Europeia dos Direitos Humanos não contém em seu texto norma expressa sobre as fontes de informações dos jornalistas. Todavia, a proteção das fontes é inferida do artigo 10 o qual assegura, com amplitude, a liberdade de informação.

Da jurisprudência da Corte emana entendimento no sentido de que o artigo 10 da Convenção protege não somente a substância e o conteúdo das informações e das ideias, mas também os meios pelos quais eles são difundidos. Assim, confere à imprensa uma proteção extremamente importante, estendendo a liberdade de informação à proteção da confidencialidade das fontes jornalísticas, contudo, não a entende inquebrantável em determinadas circunstâncias de justificável interesse público.

As situações em que o Tribunal reconheceu o direito ao sigilo da fonte são aquelas concernentes às ordens provindas das autoridades policiais e judiciárias para a divulgação e busca e apreensão de materiais jornalísticos de investigação.

O Tribunal Europeu de Direitos Humanos, pela primeira vez, enfrentou o assunto do direito dos jornalistas ao anonimato das fontes, no caso Goodwin v. Reino Unido, quando decidiu pela inclusão desse direito no enunciado do reconhecimento genérico da ampla liberdade de expressão e informação, previsto no artigo 10 da Convenção Europeia.

O jornalista britânico William Goodwin, da revista The Engineer, sob a promessa de proteger a identidade do informante, recebeu notícia sobre a difícil situação econômicofinanceira da empresa Tetra Ltd, exatamente quando ela realizava um empréstimo financeiro para reestruturar-se economicamente. Ao tentar confirmar os fatos com a empresa, essa verificou que a informação sobre seu "plano confidencial" de reestruturação econômica havia sido transmitido à imprensa. Conseguiu então, junto a High Court of Justice, medida cautelar para que os editores da revista The Engineer se abstivessem de divulgar qualquer informação sobre o plano da empresa. Outro pedido, acolhido pela

\footnotetext{
${ }^{195}$ Cf. Capítulo I.
} 
Justiça, embasado na Lei Contempt of Court Act, consistiu na entrega, pelo jornalista, das anotações feitas acerca da notícia que recebeu sobre a empresa, a fim de que pudesse ser identificada a fonte e essa, então, fosse punida.

O profissional, no entanto, recusou-se ao cumprimento da ordem judicial. A Corte de Apelo e a Corte dos Lordes confirmaram o acerto da decisão judicial contra o jornalista. Esse foi condenado por desacato (contempt of court), pois descumpriu as ordens judiciais.

William Goodwin, portanto, recorreu ao Tribunal Europeu de Direitos Humanos alegando ter sido ofendido no seu amplo direito à liberdade de imprensa. Em março de 1996, a Corte Europeia decidiu que "a proteção das fontes jornalísticas é uma das pedras angulares da liberdade de imprensa [...], como decorre das leis e códigos deontológicos de inúmeros Estados, e como afirmam muitos instrumentos internacionais sobre as liberdades jornalísticas. A ausência de tal proteção poderia dissuadir as fontes a ajudar a imprensa a informar e publicar questões de interesse geral. Em consequiência a imprensa deixaria de representar seu papel indispensável de cão de guarda e, sua aptidão de fornecer as informações precisas e confiáveis poderiam encontrar-se diminuídas [...]. Uma ordem de divulgação não seria conciliável com o artigo 10 da Convenção, ainda que se justifique por um imperativo preponderante de interesse público ${ }^{196}[. .$.$] , dada a importância que reveste a$ proteção das fontes jornalísticas, para a liberdade de imprensa, em uma sociedade democrática" ${ }^{197}$ O Tribunal declarou que, no caso, não houve uma razoável relação de proporcionalidade entre a ordem judicial de revelar a fonte, bem como a multa imposta excessiva e desnecessária numa sociedade democrática - e o fundamento, objetivo da medida imposta.

Nas diversas decisões dos casos submetidos à Corte Europeia de Direitos Humanos, encontraremos, quase que sistematicamente, os fundamentos acima elencados.

Em 21 de janeiro de 1999, foi julgado na Corte de Estrasburgo o caso Fressoz e Roire v. França, cujo litígio consistia na publicação de informações cobertas pelo segredo

\footnotetext{
${ }^{196}$ EUROPEAN COURT OF HUMAN RIGTHS. http://www.echr.coe.int/NR/rdonlyres/ODF78992-B7F04CA7- /FICHES_Protection_des_sources_journalistiques_FR.pdf. Acesso 04 de jul. 2011.

${ }^{197}$ DERIEUX, Emmanuel. GRANCHET, d’Agnès. Droit des medias. Droit Français, Européen et International. 6.ediction, Paris: Lextenso, 2010, p.959.
} 
profissional fiscal, no jornal Le Canard encahiné. Trata-se de uma divulgação feita no mencionado periódico, do aumento salarial do presidente Jacques Calvet, da empresa automobilística Peugeot, em momento de crise financeira, quando os funcionários reivindicavam melhorias salariais. O texto da notícia veio ilustrado com fotocópias de documentos onde constavam os valores financeiros auferidos pelo então presidente. Os jornalistas foram condenados por receptação de declaração de impostos e salários de Calvet, oriundos de crime de violação de segredo profissional de funcionários. Recorreram à Corte de Direitos Humanos alegando terem sido violados no direito previsto no artigo 10 da CEDH. O Tribunal entendeu que a informação divulgada era de relevante interesse social e que "a proteção das informações como confidenciais não constituía, no caso concreto, um imperativo preponderante. Como o Governo admite - continuou - as informações sobre o montante dos rendimentos anuais de Calvet eram lícitas e a sua divulgação autorizada, daí que a condenação dos argüidos, por terem publicado o respectivo suporte, não se justificaria à luz do artigo 10 da Convenção. [...]"198. Concluiu a Corte que, in casu, deveria prevalecer o princípio da liberdade de imprensa na sociedade democrática e, portanto, a condenação dos jornalistas violou o artigo 10 da Convenção.

A Corte Europeia teve a oportunidade de julgar um caso no qual o jornalista, para realizar reportagem sobre pedofilia na Dinamarca, infiltrou-se com falsa identidade em uma associação pedófila. Investigado, a Corte decidiu que a ingerência do profissional na mencionada associação foi proporcional à sua liberdade de expressão, pois perseguia um objetivo legítimo: a prevenção do crime, em particular as infrações graves cometidas contra menores. (Nordisk Film \& TV A/S v. Danemark, 08.12.2005). ${ }^{199}$

Ao julgar o caso Voskuil c. Pays-Bas, em 22 de novembro de 2007, no qual o jornalista foi condenado pela Justiça holandesa por negar-se a divulgar a fonte de informação, a Corte concluiu pela violação ao artigo 10 da CEDH.

Em outra oportunidade, em 15 de dezembro de 2009, no caso Financial Times Ltd ET autres c. Royaume-Uni, a Corte considerou que a participação de jornalistas na

\footnotetext{
${ }^{198}$ ROCHA, Manuel António Lopes. A liberdade de expressão como direito do homem. Sub judice: justiça e sociedade, Lisboa, Junho/Dezembro, n. 15/16, 1999, p. 16.

${ }^{199}$ EUROPEAN COURT OF HUMAN RIGTHS. http://www.echr.coe.int/NR/rdonlyres/ODF78992-B7F04CA7-/FICHES_Protection_des_sources_journalistiques_FR.pdf. Acesso em 04 jul. 2011.
} 
identificação de fontes anônimas teria um efeito inibidor e a balança pendeu em favor de um interesse público à proteção das fontes jornalísticas. ${ }^{200}$ (violação do artigo 10 da Convenção).

Em 14 de setembro de 2010, foi julgado pela Corte o caso Sanoma Uitgevers B.V. c. Pays-Bas, no qual se decidiu que a identificação das fontes pelos jornalistas, para fins de investigação de infração penal, seria ingerência na liberdade de expressão não prevista pela lei. A apreensão de material jornalístico poderia ter um efeito inibidor sobre o exercício da liberdade de expressão jornalística. ${ }^{201}$ (violação do artigo 10 da Convenção).

O Tribunal protegeu a fonte de informação do jornalista em caso no qual o profissional era o acusado. No caso De Haes and Gijsels versus Belgium, jornalista e editor foram condenados por difamação a membros do Poder Judiciário. Durante o processo, na exceção da verdade, recusaram-se a revelar a fonte, e as provas dos autos não foram consideradas suficientes para que eles comprovassem as alegações. Em 24 de fevereiro de 1997, o Tribunal Europeu de Direitos Humanos decidiu que a recusa dos acusados na apresentação de documentos que poderiam revelar as fontes, foi legítima e encontrava-se protegida pelo Artigo 10 da Convenção. ${ }^{202}$

A Corte Europeia também decidiu pela violação do artigo 10 da Convenção em casos nos quais houve busca e apreensão no domicílio ou no lugar de trabalho dos jornalistas.

Nos casos Roemen et Schimitt c. Luxembourg (25.02.2003) e Ernst c. Belgique (15.07.2003), a Corte julgou que incumbia às autoridades demonstrar que outras medidas diversas das buscas e apreensões praticadas no domicílio e no lugar de trabalho dos jornalistas, como a oitiva de pessoas, seriam insuficientes para assegurar a defesa da ordem e a prevenção das infrações. ${ }^{203}$

\footnotetext{
${ }^{200}$ EUROPEAN COURT OF HUMAN RIGTHS. http://www.echr.coe.int/NR/rdonlyres/0DF78992-B7F04CA7-/FICHES_Protection_des_sources_journalistiques_FR.pdf. Acesso em 04 jul. 2011.

${ }^{201}$ EUROPEAN COURT OF HUMAN RIGTHS. http://www.echr.coe.int/NR/rdonlyres/ODF78992-B7F04CA7- /FICHES_Protection_des_sources_journalistiques_FR.pdf. Acesso em 04 jul. 2011.

${ }^{202}$ EUROPEAN COURT OF HUMAN RIGHTS. Ecourthd, 24 fev. 1997. De Haes and Gijsels v. Belgium. Disponível em www.echr.coe.int, Acesso em 04 jul. 2011.

${ }^{203}$ EUROPEAN COURT OF HUMAN RIGTHS. http://www.echr.coe.int/NR/rdonlyres/ODF78992-B7F04CA7-/FICHES_Protection_des_sources_journalistiques_FR.pdf. Acesso em 04 jul. 2011.
} 
No primeiro caso, a polícia, munida de mandado judicial, realizou busca e apreensão no domicílio de um jornalista, que publicou artigo sobre fraude fiscal cometida por um ministro. A Corte julgou que as medidas litigiosas eram desproporcionais e os motivos sobre os quais elas se apoiaram, eram insuficientes, violando, entre outros, o artigo 10 da Convenção de Direitos Humanos.

No caso Ernst, também foi feito trabalho de buscas dirigidas nos locais de um jornal belga e nos domicílios respectivos de quatro jornalistas, os quais tinham informações sobre investigações de membros do Ministério Público, que estavam sendo acusados de violação de segredo profissional perante a Corte de Apelo de Liége. A Corte julgou que os motivos invocados pelas jurisdições internas não eram suficientes para justificar as buscas e apreensões de tal envergadura, violando, assim, entre outros, o artigo da Convenção.

Outros casos referentes ao sigilo profissional dos jornalistas, sobretudo no que respeita às buscas e apreensões de materiais informativos nos domicílios e locais de trabalho dos profissionais, foram submetidos a julgamento pela Corte. No processo do jornalista Tillack (versus Bélgica), ficou sublinhado que o direito dos jornalistas de calarem-se sobre suas fontes não pode ser considerado um simples privilégio, mas um verdadeiro atributo do direito à informação, a ser tratado com a maior seriedade. ${ }^{204}$

A consagração desse direito ao sigilo da fonte de informação, na Corte Europeia de Direitos Humanos deriva de uma elaboração jurisprudencial. Concluímos que o Tribunal de Estrasburgo reconhece o fundamento de serviço público da informação pela imprensa, razão pela qual os jornalistas são privilegiados legítimos e beneficiários naturais $^{205}$ da liberdade prevista no artigo 10 da Convenção.

\footnotetext{
204 EUROPEAN COURT OF HUMAN RIGTHS. http://www.echr.coe.int/NR/rdonlyres/0DF78992-B7F04CA7- /FICHES_Protection_des_sources_journalistiques_FR.pdf. Acesso em 04 jul. 2011. Em julgamento o caso Uitgeversmaatschappij De Telegraaf B. V. et autres c. Pays-Bas, sobre a apreensão de documentos provenientes de serviços nacionais, no escritório de um jornal, bem com escutas telefônicas em face de dois jornalistas, visando a identificação das fontes.

${ }^{205}$ As expressões foram usadas por Mathilde Hallé no seu livro Discours politique et Cour européenne dês droits de l'homme. Fondements et limites de La liberte d'expression politique dans la jurisprudence de la Cour de Strasbourg. Bruxelles: Bruylant, 2009, p. 40.
} 
Todavia a ausência de norma expressa na Convenção leva a Corte a fixar, ela própria, o que entende necessário e inevitável limite a esse direito. Assim, de uma breve análise (também quantitativamente limitada) da jurisprudência da Corte, na qual se deduz que a balança pende em favor da liberdade de expressão e do direito à informação dos jornalistas, esse Tribunal admite que, em algumas situações, o direito à não revelação da fonte seja restringível, pois como qualquer outro, não pode ser absoluto.

O estudo dos limites à proteção do sigilo da fonte, no entanto, será feito em capítulo próprio. Neste ponto do trabalho, objetivamos, tão somente, colocarmos a ampla proteção dada pela jurisprudência da Corte Internacional de Direitos Humanos, ao segredo profissional dos jornalistas.

\subsection{O sigilo da fonte no Sistema Interamericano de Direitos Humanos}

O sigilo da fonte no sistema americano de direitos humanos, mais propriamente o alcance de seu sentido na interpretação do Tribunal de Costa Rica ${ }^{206}$, não pode ser entendido se apartado do contexto histórico das Américas, região onde as democracias ainda estão sendo consolidadas.

Encontramos exclusões e desigualdades sociais na região que "convive com as reminiscências do legado dos regimes autoritários ditatoriais, com uma cultura de violência e de impunidade, com baixa densidade de Estados de Direito e com a precária tradição de respeito aos direitos humanos no âmbito doméstico ${ }^{207 ", .}$

Quando entrou em vigor a Convenção Americana de Direitos Humanos, com o propósito de sedimentar as liberdades pessoais no Continente Americano, havia muitos governos ditatoriais nos Estados da América Central e do Sul, os quais violavam os direitos e liberdades dos indivíduos, por meio de torturas, prisões ilegais, execuções sumárias, desaparecimentos forçados, além de uma ausência absoluta de justiça social.

\footnotetext{
206 Sobre a Corte Interamericana, ver PÉREZ, Marvin Carvajal. O Tribunal Constitucional da Costa Rica. Revista da Faculdade de Direito da USP, São Paulo, v. 91, 1996, p. 201-219.

${ }^{207}$ PIOVESAN, Flávia. Direitos Humanos e Justiça Internacional. São Paulo: Saraiva, 2007, p. 85.
} 
Ora, o respeito aos direitos sociais, políticos e econômicos culturais dos indivíduos é pressuposto para a consolidação de uma democracia. E conforme acontecia a transição de regimes autoritários, para aqueles de governos democráticos, esses precisavam consolidarse realizando, com eficácia, os direitos humanos declarados.

Todavia, embora seja essencial o papel do Estado para a concretização dos ideais da democracia e, por consequência, para assegurar os direitos dos seus cidadãos, cabe a esses a definição de valores, a exigência de efetiva participação nos rumos do Estado, repudiando toda ordem de exclusão social ou ofensa aos direitos inerentes ao ser humano.

Daí a importância da Comissão ${ }^{208}$ e da Corte Interamericana de Direitos Humanos como instrumentos para fazer valer o dever do Estado em relação aos direitos dos seus cidadãos. ${ }^{209}$ Estes órgãos ${ }^{210}$ não somente determinam a implementação, as mudanças ou

208 Sobre a Comissão Interamericana de Direitos Humanos, ver: Principais instrumentos do sistema interamericano de promoção e proteção dos direitos humanos. A Comissão Interamericana de Direitos Humanos: como é e como funciona. Edição resumida do manual de normas vigentes. Organização dos Estados Americanos, Washington, 1994.

209 Sustenta Cançado Trindade que “da Declaração Universal de 1948 até nossos dias, os instrumentos internacionais voltados ao propósito comum de salvaguarda dos direitos humanos formam um corpus de regras bastante complexo [...]. Esses mesmos mecanismos se complementam uns aos outros no desempenho de suas funções e na realização do propósito comum de assegurar uma proteção eficaz e cada vez mais extensa aos indivíduos lesados". Cf. A proteção internacional dos direitos humanos: fundamentos jurídicos e instrumentos básicos. São Paulo: Saraiva, 1991, p. 3.

${ }^{210}$ A Comissão Interamericana de Direitos Humanos, criada inicialmente para funcionamento provisório até a elaboração de uma Convenção, teve a finalidade precípua de promover o respeito aos direitos humanos consagrados na Declaração Americana, entre os Estados-membros da OEA: Conforme art. 106 da Carta da OEA, "Haverá uma Comissão Interamericana de Direitos Humanos que terá por principal função promover o respeito e a defesa dos direitos humanos e servir como órgão consultivo da Organização em tal matéria. Uma Convenção Americana estabelecerá a estrutura, a competência e as normas de funcionamento da referida Comissão, bem como a de outros órgãos encarregados de tal matéria". Aliás, seu Estatuto aprovado e aditado em 1960, pelo Conselho da OEA, não lhe conferia outros poderes e não continha qualquer atribuição judiciária. Hoje, como entidade autônoma da Organização dos Estados Americanos (OEA) e órgão da Convenção Americana, além da finalidade de promover e proteger os direitos humanos no continente americano, funcionando ao lado da Corte Interamericana de Direitos Humanos e da Assembléia Geral da OEA, supervisiona e monitora "o grau de cumprimento das obrigações internacionais pelos Estadosmembros em matéria de direitos humanos no âmbito regional". A Corte Interamericana de Direitos Humanos, órgão da Convenção Americana de Direitos Humanos, é uma instituição judiciária internacional - do sistema regional - autônoma, instalada em 3 de setembro de 1979, após o $11^{\circ}$ instrumento de ratificação. Foi criada na Convenção Americana sobre Direitos Humanos, em 1969, em San José da Costa Rica e teve seu Estatuto aprovado em 1979, na Assembléia Geral da OEA. O Brasil reconheceu a competência jurisdicional da Corte Interamericana de Direitos Humanos em 03 de dezembro de 1998, através do Decreto Legislativo n. 89210, obrigando-se a implementar suas decisões e devendo seguir, internamente, a orientação das Opiniões Consultivas da Corte. Cf. GALli, Maria Beatriz; DULITZKY, Ariel E. A Comissão Interamericana de Direitos Humanos e o seu papel central no sistema interamericano de proteção dos Direitos Humanos. In Luiz Flávio Gomes e Flávia Piovesan (Coord.), O sistema interamericano de proteção dos Direitos Humanos e o Direito brasileiro, São Paulo: RT, 2000, p. 53-54. 
fixação de valores reclamados, mas também fiscalizam o fiel cumprimento dos direitos humanos nos países da América Latina. ${ }^{211}$

Nos países latino-americanos ${ }^{212}$, muito ainda tem-se a conquistar. A democracia, nas palavras de José Afonso da Silva, é "um processo dialético, e um processo dialético que vai rompendo os contrários, as antíteses, para, a cada etapa da evolução, incorporar conteúdo novo, enriquecido de novos valores" ${ }^{213}$. E é nesse contexto de desenvolvimento da cultura e luta para assegurar valores democráticos, que verificamos, nos países da América, um crescente desenvolvimento doutrinário e jurisprudencial da questão atinente à liberdade de expressão e informação, bem como dos instrumentos para garanti-la. Justificase, na medida em que essa liberdade é, em todo o mundo, considerada instrumento de realização democrática.

\subsubsection{O segredo jornalístico no âmbito de proteção da liberdade de imprensa}

Não encontramos, até o momento da elaboração desta pesquisa, qualquer decisão da Corte Interamericana sobre o sigilo da fonte. Aliás, como já salientamos, também não há qualquer proteção expressa do segredo jornalístico na Convenção Americana de Direitos Humanos.

211 “Atuam paralelamente com o sistema global os sistemas regionais que vêm revelando extraordinária experiência no campo da justicialização dos direitos humanos, por meio da criação de Cortes de Direitos Humanos. Tais Cortes têm procurado guiar-se por considerações de ordre public, atuando acima da vontade individual dos estados e contribuindo, desse modo, para a construção de um sistema jurídico internacional fundamentado na observância dos direitos humanos em toda e qualquer circunstância”. Cf. ARRUDA, Eloísa de Sousa. Direitos Humanos - O descompasso entre a fundamentação e a efetiva promoção. MALHEIROS, Antonio Carlos, BACARIÇA, Josephina, VALIM, Rafael (Coords.). Direitos Humanos: desafios e perspectivas. Belo Horizonte: Editora Fórum, 2011, p. 19. Sobre a Corte Interamericana, ver ainda, CORREIA, Theresa Rachel Couto. Corte Interamericana de Direitos Humanos: repercussão jurídica das opiniões consultivas. Curitiba: Juruá, 2008.

${ }^{212}$ A título de informação, vale ressaltar o reconhecimento do sigilo da fonte pela Constituição do Paraguai: Capítulo, II, artigo 29: "O exercício do jornalismo, em qualquer de suas formas, é livre e não está sujeito à autorização prévia. Os jornalistas dos meios de comunicação social, em cumprimento de suas funções, não serão obrigados a agir contra os ditames de sua consciência, nem revelar suas fontes de informação [...]".Disponível em: http//www.oas.org/juridico/mla/sp/pry/sp_pry-int-text-const.pdf. Acesso em $18 \mathrm{dez}$. 2010.

${ }^{213}$ SILVA, José Afonso da. Curso de Direito Constitucional Positivo. 24. ed. rev. e atual. São Paulo: Malheiros, 2005, p. 129. 
Contudo, não poderemos deixar de considerar a proteção desse Tribunal à liberdade de informação, na qual está inserido o sigilo em estudo. Primeiro porque, como vimos, o segredo profissional dos jornalistas vem tomando dimensão crescente nas Relatorias e Declarações subscritas pelos Estados da América, como instrumento de auxílio no desenvolvimento das democracias. Em segundo lugar, sem a proteção desse direito, pouco provável que a liberdade de imprensa no sistema interamericano de direitos humanos possa ser atingida conforme a amplitude prevista na Convenção Americana. E, portanto, não tardará para que a Corte seja instada a se pronunciar sobre violação, pelo Estado, deste poderoso direito instrumental dos profissionais dos meios de comunicação, sobretudo no momento atual de sedimentação das liberdades sociais e dos direitos humanos na América.

Portanto, ao analisarmos o entendimento da Corte acerca do artigo 13 da Convenção Americana - Liberdade de Pensamento e Expressão -, poderemos concluir que, assim como a Corte Europeia considerou o segredo jornalístico no âmbito de proteção da ampla liberdade de expressão e informação (Artigo 10), o Tribunal Interamericano de Direitos Humanos, frente a um caso concreto de sigilo da fonte, também poderá seguir o mesmo método de interpretação para outorgar-lhe proteção. ${ }^{214}$

Aqui, é mister esclarecer que além da utilização pela Corte Interamericana do método interpretativo sobre o sigilo da fonte, feito pela da Corte Europeia, aquela poderá utilizar a jurisprudência do sistema europeu como "normas mínimas" "215 que a liberdade de expressão exige. Primeiramente porque, a Corte de Estrasburgo é uma "jurisdição internacional que aplica o direito internacional" ${ }^{216} \mathrm{e}$, em segundo lugar, porque indica princípios gerais que devem ser comuns aos Estados-membro, como contributo para harmonizar os sistemas jurídicos de todos os países. ${ }^{217}$

\footnotetext{
${ }^{214}$ Adrian Ventura considera necessário o estudo da liberdade de imprensa no sistema interamericano de direitos humanos, como base para supor que, diante de um caso onde o segredo estará comprometido, a Corte poderá outorgar-lhe ampla proteção. Para o autor, a Convenção possui normas regulamentadoras da liberdade de imprensa, mais "generosas" do que as constantes na Convenção Européia dos Direitos Humanos, razão pela qual entende haver "muitos motivos para considerar que o segredo deveria receber uma proteção muito ampla, igual ou, inclusive superior a que recebe no sistema europeu de direitos humanos. Por outra parte, a Relatoria sobre Liberdade de Expressão e a Declaração de Chapultepec fazem menção expressa à proteção do segredo jornalístico". Cf. Liberdad...cit., p. 275.

${ }^{215}$ VENTURA, Adrian. Libertad...cit., p. 276.

${ }^{216}$ CASSESE, Antonio. A influência da CEDH sobre a atividade dos Tribunais Penais Internacionais. DELMAS-MARTY, Mireille; CASSESE, Antonio (Coord.). Crimes internacionais e jurisdições internacionais. Tradução de Silvio Antunha. Barueri, SP: Manole, 2004, p. 179.

${ }^{217}$ A colocação foi feita por CASSESE, Antonio. A influência da CEDH ...cit., p180.
} 
Anotamos, a título de exemplo da interação de conceitos interpretativos dos textos internacionais sobre direitos humanos, a OC 5/85 (46) da Corte Interamericana: “ importante destacar que a Corte Europeia de Direitos Humanos ao interpretar o artigo 10 da Convenção Europeia, concluiu que necessárias, sem ser sinônimo de indispensáveis , implica a existência de uma necessidade social imperiosa e que para que uma restrição seja necessária não é suficiente demonstrar que seja útil, razoável e oportuna . (Eur. Court H. R., The Sunday Times case, judgment of 26 April 1979, Series A n. 30, párr. $n$. 59, págs. 35-36). Essa conclusão, que é igualmente aplicável na Convenção Americana, sugere que a necessidade e, portanto, a legalidade das restrições à liberdade de expressão fundadas no artigo 13.2, dependerá de que estejam orientadas a satisfazer um interesse público imperativo. Entre várias opções para alcançar esse objetivo deve escolher-se aquela que restrinja em menor escala o direito protegido [...] ver também Eur. Court H. R., Barthold judgment of 25 March 1985, Series A n. 90, párr. n. 59, pág. 26) [...] Na verdade, frequentemente é útil, como acaba de fazer a Corte, comparar a Convenção Americana com o disposto em outros instrumentos internacionais como meio para por em relevo aspectos particulares da regulamentação de um determinado direito, porém tal método não poderia empregar-se, nunca, para incorporar à Convenção critérios restritivos que não se depreenda diretamente de seu texto, por mais que estejam presentes em qualquer outro tratado internacional" ( 51$).^{218}$

Nosso objetivo, no entanto, não é a análise aprofundada dos inúmeros casos nos quais a Corte Interamericana teve a oportunidade de interpretar o Artigo 13 da Convenção, mas tão só verificar, a partir de algumas decisões já prolatadas, ou de Opiniões Consultivas $^{219}$, que a ausência de proteção expressa do sigilo da fonte, na Convenção, não o infirmará como direito a ser assegurado perante o Tribunal da Costa Rica.

218 A Opinião Consultiva OC-5/85 de 13 de novembro de 1985, foi solicitada pelo Governo de Costa Rica sobre a interpretação dos artigos 13 e 29 da Convenção Americana de Direitos Humanos, em relação à associação obrigatória dos jornalistas e sobre a compatibilidade da Lei 4420 de 22 de setembro de 1969- Lei Orgânica do Colégio de Jornalistas de Costa Rica - com as disposições dos mencionados artigos. Segundo declaração expressa do Governo, essa solicitação de opinião foi formulada em cumprimento de um compromisso assumido com a Sociedade Interamericana de Imprensa. (CF, OC - 5/85, 1). Cf. http://www.corteidh.org.cr/opiniones.cfm. Acesso em: 14 jun. 2011.

219 Além da função jurisdicional, a Corte Interamericana de Direitos Humanos também possui a função de caráter consultivo. As Cortes, porque possuem competência consultiva, independentemente de casos contenciosos, podem interpretar normas jurídicas internacionais à luz da Convenção Americana. Os pareceres consultivos da Corte estabelecem princípios jurídicos que contribuem para o desenvolvimento dos Direitos Humanos na sua área de abrangência. Não deixa de criar uma verdadeira jurisprudência enquanto firma posições sobre os assuntos colocados à sua apreciação. Segundo André Ramos de Carvalho, "forma-se a 


\subsubsection{A interpretação do artigo 13 da Convenção Americana de Direitos Humanos pelo Tribunal da Costa Rica}

A OC $n^{\circ} 5 / 85$ foi a primeira pronúncia da Corte Interamericana sobre os atos compreendidos no direito à liberdade de expressão e informação. O Tribunal assinalou que o artigo 13 da Convenção não permite restrição ilegal à liberdade de expressão de um indivíduo, pois a violação individual a esse direito atinge, na mesma medida, o direito de todos a receber informações e ideias, concluindo que o direito protegido tem conteúdo e alcance especial. ${ }^{220}$

A dupla dimensão - individual e social - da liberdade de expressar ideias e difundir informações foi afirmada de modo categórico na OC 5/85, decorrendo daí os atos nela compreendidos de buscar, receber e divulgar informações, sem censura prévia, que devem estar conectados ao direito de imprensa e do profissional da mídia. E, finalmente, ressalta que "o abuso da liberdade de expressão não pode ser objeto de medidas de controle preventivo, senão fundamento de responsabilidade para quem o cometeu"221. Ainda neste caso, para que tal responsabilidade possa estabelecer-se validamente, devem ser impostas por leis e somente para atingir fins determinados pela própria Convenção.

Quanto à questão da censura prévia, a Corte teve a oportunidade de se manifestar no caso Olmedo Bustos e outros vs. Chile, de 5 de fevereiro de 2001, segundo o qual o Estado do Chile foi responsabilizado por violar a liberdade de expressão consagrada no artigo 13 da CADH, porque em 1989 proibiu a exibição do filme "A Última Tentação de Cristo", após reações contrárias de pessoas e grupos ligados à religião católica, que

chamada coisa interpretada, sem força vinculante da coisa julgada, mas, em uma sociedade internacional na qual os sujeitos de direito são, ao mesmo tempo, produtores e aplicadores das normas, o órgão judicial internacional figura como exceção a tal situação. Assim, essas interpretações têm o condão de firmar o que é o Direito na esfera interamericana de proteção aos direitos humanos sem os vieses unilaterais dos Estados." Cf. Direitos humanos em juízo. Comentários aos casos contenciosos e consultivos da Corte Interamericana de Direitos Humanos. São Paulo: Max Limonad, 2001, p. 347. Ressalte-se, ainda, a fonte normativa da função consultiva da Corte: o art. 64 da Convenção Americana atribui à Corte a competência consultiva. E, segundo João Grandino Rodas, “A Corte Interamericana de Direitos Humanos possui competência consultiva mais ampla que a Corte Europeia de Direitos Humanos, pois o direito de pedir opinião consultiva não é limitado aos Estados partes na Convenção, podendo, além disso, outros tratados relativos à proteção dos Direitos Humanos no âmbito americano, serem objeto de opinião consultiva." Cf. : A Corte Interamericana dos Direitos Humanos. Revista do Curso de Direito da Universidade Federal de Uberlândia. 10 (1 e 2), 1981, p. 180-181.

${ }^{220}$ Item 30 da OC 5/85.

${ }^{221}$ Item 39 da OC 5/85. 
alegavam violação à liberdade de consciência consagrada na Constituição política da República do Chile. ${ }^{222}$

Antes, porém, em 1966, a Comissão IDH já havia tratado da questão da censura prévia no caso Grenada, Steve Clark y otros, ${ }^{223}$ no qual concluiu pela violação do artigo 13 da CADH porque o Estado confiscou livros importados dos Estados Unidos, assim que as caixas chegarem ao aeroporto. No mesmo sentido, de violação da liberdade de expressão, foi a conclusão no caso Chile, Francisco Martorell, de $1996,{ }^{224}$ no qual o Estado proibiu a publicação de um livro que relatava as circunstâncias do abandono do país, do Embaixador Argentino no Chile.

Sobre a responsabilidade da mídia no exercício da função social, relevante o Caso Kimel vs. Argentina, sentença de 02 de maio de 2008, referente a um jornalista e escritor que escreveu, entre outros, o livro "La Massacre de San Patricio", no qual relatou as investigações sobre o assassinato de cinco religiosos e fez críticas à atuação das autoridades de Estado encarregadas da investigação, inclusive um juiz. Kimel foi condenado em processo criminal à prisão e multa. $\mathrm{O}$ caso foi levado à Corte Interamericana e o Estado argentino assumiu a responsabilidade internacional por violação ao artigo 13 da CIDH.

Releva anotar, primeiramente, que a Comissão considerou que este caso representaria uma "oportunidade para o desenvolvimento da jurisprudência interamericana sobre a incompatibilidade das leis que criminalizam as expressões e opiniões críticas sobre como os agentes do Estado exercem suas funções." ${ }^{225} \mathrm{Na}$ decisão, a Corte concluiu que existe uma responsabilidade social da imprensa na transmissão de informações, e para esse mister os jornalistas têm o direito de buscar e o dever de constatar os fatos de modo razoável, porque a sociedade tem o direito de receber versão não manipulada sobre os acontecimentos. $^{226}$

\footnotetext{
222 ILSON, Alex Mu oz. Caso "La Última Tentación de Cristo". Reflexiones em torno al primer fallo sobre libertad de expresión en el sistema americano de derechos humanos. In: FRANCHINI, María Belém y otros (Coord). Libertad de Expresión y Democracia desde uma perspectiva latinoamericana. Buenos Aires: Fabian J. di Placido, 2002, p. 97-42.

${ }^{223}$ Caso 10.325, Informe n. 2/96. Cf. Ventura, Adrian. Libertad.....cit. p. 281.

${ }^{224}$ Caso 11.230, Informe n. 11/96. Cf. Ventura, Adrian. Libertad...cit. p. 281.

${ }^{225} \mathrm{http} / / /$ www.corteidh.or.cr/docs/comunicados/CIDH_CP-11-07Esp1.pdf. Acesso em: 04 ago. 2011.

${ }^{226} \mathrm{http} / / / \mathrm{www} . c o r t e i d h . o r . c r / d o c s / c a s o s / a r t i c u l o s / s e r i e c \_177 \_e s p . p d f$. Acesso em: 04 ago. 2011.
} 
O Tribunal de Costa Rica pronunciou-se, também quanto à proibição de restrições ilegítimas, por meios indiretos, colocados para buscar e receber informações, o que viola o artigo 13, 3 da CADH. No caso Ivcher Bronstein vs. Peru, ${ }^{227}$ de 06 de fevereiro de 2001, a Corte fez constar que a liberdade de expressão não era, tão somente, a satisfação de uma obrigação de respeito, mas consistia, inclusive, em obrigações positivas do Estado de proteção e garantias de independência e de acesso à diversidade das fontes, dirigidas aos jornalistas, já que são eles que informam a sociedade. ${ }^{228}$

Analisando essa decisão, Luis M. Garcia entendeu que, não obstante a ausência de menção ao segredo das fontes, a Corte IDH, ao afirmar sobre a necessidade de proteção e garantias de independência dos profissionais da comunicação, poderia, a partir da mencionada decisão, desenvolver o fundamento de um direito ao segredo jornalístico. Com efeito, as obrigações positivas do Estado abrangeriam, inclusive, a necessidade de resguardar o direito de os jornalistas não serem compelidos pelas autoridades estatais, sem justificação pertinente e suficiente, a revelar a identidade das fontes, sob pena de violação do artigo 13 da $\mathrm{CADH}$, pois tais atos caracterizariam ingerências ou restrições indiretas à liberdade de expressão e informação. ${ }^{229}$

No caso Townsend Diez-Conseco y otros vs. Perú, de 19 de janeiro de 2001, alegou-se que a interceptação sistemática das comunicações telefônicas dos jornalistas violava o direito à liberdade de expressão. Embora não haja menção expressa ao segredo da fonte, sem dúvida que a petição formulada perante a Comissão IDH visava a resguardar a fonte como instrumento da liberdade de expressão garantida no artigo 13 da CIDH. ${ }^{230}$

É possível concluirmos que a Corte Interamericana, se instada a decidir casos que envolvam o sigilo da fonte de informação jornalística, poderá sustentar suas decisões no

\footnotetext{
${ }^{227}$ O caso refere-se a um cidadão naturalizado do Peru, acionista majoritário de um Canal de televisão do país, que teve revogada sua cidadania peruana e foi afastado do controle do Canal. A Corte considerou que "a resolução que tornou sem efeito legal o título de nacionalidade do senhor Ivcher constituiu um meio indireto para restringir sua liberdade de expressão, assim como dos jornalistas que trabalhavam para o programa Contraponto do Canal 2 da televisão peruana”. Corte IDH, Caso Ivcher Bronstein, Serie C, n. 74, sentença de 06 de fevereiro de 2001, $\$ 162$.

${ }^{228}$ Corte IDH, Ivcher Bronstein vs. Perú, § 149/150.

${ }^{229}$ GARCÍA, Luis M. La protección de la identidad de las fuentes periodísticas a la luz de los instrumentos internacionales de derechos humanos y de los estándares de sus órganos de aplicación. In: Anuario de Derecho Constitucional Latinoamericano/2004. p. 645-646. www.juridicas.unam.mx. Acesso em: 12 jul. 2011.

${ }^{230}$ Petição 12.085, inf. N. 1/2001 dirigida à Comissão Interamericana de Direitos Humanos.
} 
artigo 13 da CIDH, e ainda, terá como suporte jurídico para fundamentar as sentenças as Declarações e Pactos nos quais consta aquele direito. Isso se deduz pela abrangência com a qual interpreta o direito à liberdade de informação e expressão. 


\section{JORNALISMO INVESTIGATIVO, BUSCA DA VERDADE E PROVA PENAL}

A análise do segredo profissional do jornalista, como limite à prova no processo penal, exige um desenvolvimento, mais preciso, da abrangência do direito fundamental à informação, no que concerne à atividade da mídia de informar-se para informar.

Procuraremos demonstrar que a elaboração das notícias, por qualquer meio de comunicação, as quais servirão para informar o público tem como ponto de partida, a possibilidade de acesso às fontes de informação, a busca e recolha de elementos que sustentem a ocorrência dos fatos perante o público, como atividades inerentes ao que podemos chamar de "investigação jornalística".

O trabalho investigativo do jornalista, sobretudo aquele que pretende descobrir fatos que envolvem corrupção, malversação de dinheiro público por autoridades, transformam-se em "grandes reportagens" que, se não dão início às investigações policiais de crimes, "concorrem" com os elementos ali hauridos, que se tornarão provas no processo penal. Mais do que isso, tornam-se "verdades jornalísticas" com o intuito de corresponderem aos fatos noticiados, e acabam por serem utilizadas como elementos para trazer a lume a verdade buscada no processo penal.

Há, portanto, uma "verdade" dos fatos buscada pelo processo comunicativo, que se contrapõe, no mais das vezes, à "verdade" buscada no processo penal, pretendendo ambas, todavia, estabelecerem-se através de provas visando ao convencimento do juiz criminal.

Daí a imprescindibilidade do estudo a que ora nos propomos, sobre o significado dessas "verdades" distintas, bem como sobre o método de desenvolvimento do processo comunicativo, e a conceituação e espécie das fontes de informação. Além disso, partindo da premissa de que a verdade dos fatos buscada pelo jornalista, não se elabora dentro de limites legais que são necessários à busca da verdade no processo penal, poderemos substanciar a relação existente entre o testemunho deste profissional e a produção probatória dos fatos delituosos, o que será feito no capítulo seguinte. 


\subsection{O jornalismo investigativo}

Com o desenvolvimento das sociedades, impõe-se uma complexa estrutura de poder, e seu funcionamento não é facilmente compreendido pelo cidadão. As relações sociais, econômicas e políticas se intensificam e, na mesma medida, cresce a dificuldade de visualização pública dos mecanismos da dinâmica funcional da estrutura do Estado.

Entender essa complexidade da sociedade contemporânea, buscar trazer à baila os problemas implicados no inter-relacionamento da sociedade com os poderes constituídos, é tarefa que exige componentes específicos como a possibilidade de pesquisar à exaustão, checar informações e divulgá-las para orientação do público. Nesse mister, o jornalismo investigativo é grande cooperador, e assume relevante papel de tornar visível a realidade social. $^{231}$

Após a Segunda Guerra Mundial, desenvolve-se nos Estados Unidos um novo modo de fazer jornalismo, no qual os fatos são transportados para uma narrativa, depois de submetidos pelo profissional da comunicação a uma pesquisa de todo o seu desenrolar, até ser noticiado.

Com a participação do Governo Americano, na Guerra do Vietnã, muitas críticas foram feitas à atuação dos políticos, pela imprensa, divulgadas ao mundo todo nas revistas Life e Look. Não menos importantes foram os textos publicados no New York Times e Washington Post, sobre a participação dos Estados Unidos da América nessa guerra. Em 1971, tornaram-se objetos de reportagens jornalísticas o conteúdo dos Documentos do Pentágono, até então secretos. ${ }^{232}$

${ }^{231}$ DANTAS, Audálio. A busca da informação confiável. In: LOPES, Dirceu Fernandes; PROENÇA, José Luiz. (Orgs.). Jornalismo investigativo. São Paulo: Publisher Brasil, 2003, p. 118-119.

${ }^{232} \mathrm{O}$ caso da publicação dos documentos secretos foi parar na Suprema Corte Americana que decidiu pela prevalência ao direito à liberdade de expressão, decorrente da Primeira Emenda da Constituição e enfatizou que nenhuma lei poderia ser promulgada para restringir a liberdade de imprensa. Cf. LIMA SOBRINHO, Barbosa. Direito de informação. Revista de Informação Legislativa, Brasília, ano 17, n. 67, jul-set. 1980, p. 167. 
Mas, considera-se o ano de 1972, o marco do jornalismo que se chamou de “investigativo", em virtude do caso Watergate. ${ }^{233}$ Dois jornalistas, Carl Bernstein e Bob Woodward, publicaram no diário The Washington Post, notícia de fato inicialmente comum, consistente na prisão de cinco homens que arrombaram o comitê do Partido Democrata, em Washington, para instalar aparelhos de espionagem. O fato, no entanto, desencadeou uma investigação mais detalhada, pelos jornalistas, reveladora da ligação existente entre as pessoas detidas e o coordenador de segurança do Comitê para a reeleição do Presidente Richard Nixon. O escândalo levou o Presidente a renunciar ao cargo, em 1974, sob a acusação de "mandar abafar o registro do caso". 234

O silêncio do artigo 10 da Convenção Europeia dos Direitos do Homem, quanto à liberdade de investigar, buscar informações, fez a Corte de Estrasburgo, só contemporaneamente, reconhecer e consagrar esse direito aos jornalistas, como necessário ao exercício das suas funções.

Foi no Caso Dammann vs. Suisse, de 25 de abril de 2006, no qual o jornalista M. Dammann, acusado de incitação à violação de segredo das funções, pois conseguira de um funcionário do Ministério Público, para publicar, informações sobre as pessoas condenadas por um roubo numa agência de Correios em Zurich, que a Corte manifestou-se a respeito

${ }^{233}$ Embora seja essa a opinião encontrada entre os estudiosos da Comunicação, Hugo de Burgh esclarece que “ atergate não é nem o começo do jornalismo investigativo e nem mesmo o começo de uma nova relação entre jornalistas e políticos. O jornalismo investigativo já tem uma longa história nos Estados Unidos e uma longa trajetória de exigir dos políticos que prestem contas. No início da década de 1900, a inflação causava descontentamento econômico, o poder dos novos ricos gerava ressentimentos entre as camadas urbanas majoritárias, um gigantesco número de imigrantes estava conduzindo a máquina política e, por todas essas razões, havia um cinismo com relação à política e alienação da autoridade [...]. $\mathrm{O}$ aperfeiçoamento da tecnologia de impressão e dos serviços postais tornou a expansão do mercado exeqüível, acabando por intensificar a competição pelo novo público de leitores. Esses fatores, junto com a eleição de Theodore Roosevelt como presidente em 1904, podem ter contribuído para a explosão do jornalismo investigativo naquele período." Cf. Considerações sobre jornalismo investigativo. BURGH, Hugo de (Org.). Jornalismo investigativo: contexto e prática. Trad. de Luzia Lusvarghi. São Paulo: Roca, 2008, p. 89.

${ }^{234}$ SEQUEIRA, Cleofe Monteiro de. Jornalismo investigativo: o fato por trás da notícia.São Paulo: Summus, 2005, pp. 11-12. Sobre o episódio de Watergate, Barbosa Lima Sobrinho diz que o escândalo que abalou as estruturas da democracia americana deveu-se à capacidade de investigação dos jornalistas, a partir de notícia, inicialmente, sem qualquer repercussão. Cf. Direito de informação...cit. p. 165. Leandro Fortes, apresenta detalhes do caso: "O grupo que invadiu a sede do Partido Democrata era formado por ex-membros da CIA (Agência Central de Informações). Esses ex-agentes haviam participado de outras operações secretas durante o governo de John Kennedy. A espionagem foi comandada por Gordon Liddy, ex-agente da CIA, e pelo diretor de segurança do comitê para reeleição do presidente, James MaCord. O plano tinha por objetivo montar uma fonte de vazamentos de informações - daí os integrantes terem recebido o apelido de "encanadores". ... Somente o The Washington Post, dirigido pela empresária Katharine Graham, aprofundou-se nas investigações, a partir de pistas deixadas pelos encanadores . Mas, as informações mais importantes foram dadas a Woodward, por uma fonte segura da Casa Branca, que ficou conhecida como Garganta Profunda . Cf. Jornalismo investigativo. São Paulo: Contexto, 2010, p. 21. 
da possibilidade de investigação pela mídia. No caso, como os nomes dos condenados não foram publicados, houve a ponderação de direitos personalíssimos dos réus e a impossibilidade de ingerência na liberdade de investigação do jornalista, prevalecendo essa com fundamento no artigo 10 da Convenção Europeia de Direitos Humanos. ${ }^{235}$ Hoje, a Corte vem entendendo que a liberdade de investigação é a regra e não a exceção, e serve para proteger o trabalho jornalístico. ${ }^{236}$

No Brasil, o jornalismo investigativo é realidade desde os anos de 1990, quando a abertura da mídia propiciou denúncias de corrupção envolvendo o então Presidente da República Fernando Collor de Mello e, entre outros, seu tesoureiro de campanha Paulo César Farias, culminando com o impeachment do Presidente. ${ }^{237}$

Essa maneira de fazer jornalismo, como espécie de "denúncia", já não é mais novidade no nosso país. Se por um lado foram e continuam a ser descortinados grandes esquemas de corrupção, sobretudo no âmbito do poder público, por outro, os métodos utilizados pela mídia na apuração dos fatos desconhecem os limites da ética ${ }^{238}$ e, não raro, da legalidade.

Mas o que vem a ser esse "jornalismo investigativo"?

${ }^{235}$ CEDH, Dammann VS. Zurich, 25 de abril de 2006, $4^{\text {a }}$ sect., $§ \$ 52$ e 57.

${ }^{236}$ GUEDJ, M. Alexis. Liberté et responsabilités...cit., pp. 146-147.

237 Segundo Leandro Fortes, "A Era Collor colocou em movimento um conjunto difuso de regras que, guardadas as proporções, reproduziu dentro das redações brasileiras o mesmo clima de exaltação profissional deflagrado, 30 anos antes, pelo Caso Watergate." Cf. Jornalismo...cit., p. 20. Ainda, sobre o jornalismo investigativo e seu papel no caso do impeachment do Presidente Collor de Mello, cf. FAUSTO NETO, Antonio. Vozes do impeachment. In: MATOS, Heloíza (Org.). Mídia, eleições e democracia. São Paulo: Página Aberta, pp. 159-191, 1994.

238 , ainda, Leandro Fortes que ao falar da "seperexaltação ao jornalismo investigativo", alerta para o fato de que "... a luta interna e externa de jornalistas e redações resultou em um conflito geral de interesses e métodos que precisaram ser urgentemente regulados, sob o risco de o Jornalismo - com J em caixa alta ser atirado abismo abaixo pela corrida desenfreada por cabeças de ministros e pela degola política em geral. Isso significa dizer que, na ânsia de fincar estacas de pau no coração da vampiragem nacional, as redações brasileiras começaram a perceber que já ia tarde uma discussão bem mais apurada sobre os limites dessa caçada. E mais ainda: sobre os objetivos reais dessa consumição. Nesse ponto, todos - jornalistas, fontes e patrões (salvo as exceções esperadas) - passaram a concordar em pelo menos um ponto: a premissa básica: toda a investigação jornalística tem que ser ética." Cf. Jornalismo investigativo. cit., p. 22. O Código de Ética do Jornalismo Brasileiro, no artigo 9, letra f, preceitua ser dever de todo jornalista "Combater e denunciar todas as formas de corrupção, em especial quando exercida com o objetivo de controlar a informação". Todavia, embora haja artigos explicitando a Conduta profissional do jornalista (arts. 6 ao 10 ), há menções genéricas sobre o respeito à privacidade dos cidadãos e sobre a necessidade de defender os direitos humanos. Cf. em http://www.abi.org.br. 
É o jornalismo, estreitamente vinculado à publicidade, que busca, mais do que os fatos, identificar a verdade dos acontecimentos através de uma investigação livre, destituída de regramentos, tendo como destinatário o público em geral. ${ }^{239}$

Não obstante a investigação, a pesquisa, a verificação dos fatos integrem a prática jornalística ${ }^{240}$, o processo e métodos de trabalho do profissional da mídia acaba criando uma espécie de categoria distinta daquela a qual José Marques Melo denominou “jornalismo opinativo" - que pressupõe o comentário, a crônica, o editorial -, e “jornalismo informativo" - que agrega a notícia, a reportagem e a entrevista ${ }^{241}$.

Na prática do jornalismo de investigação estão incluídas as categorias mencionadas por José Marques Melo, mas o repórter, o profissional dos meios de comunicação vai além, busca a "informação primária" de onde se origina a notícia, busca os documentos originais, faz levantamento sobre o assunto que pretende transmitir e não se limita somente às "fontes secundárias", utilizando-se dessas como meio para a "descoberta" dos fatos como "realmente ocorreram". ${ }^{242}$

O jornalismo investigativo, por conseguinte, não aceita a divulgação da notícia sem reflexão, sem avaliação, como no fast journalism ${ }^{243}$ onde a mensagem publicada é fugaz. Ao contrário, elabora a notícia, requer tempo para "montar as peças", como num jogo de “quebra-cabeça”, durante o processo de busca de elementos que vão dar forma ao fato. ${ }^{244}$

239 BURGH, Hugo de. Um nível elevado de honestidade? BURGH, Hugo de. (Org.) Jornalismo investigativo: contexto e prática. Trad. Luiza Lusvarghi. São Paulo:Roca, 2008, p. 10.

240 Nesse sentido, v.p.t. PEREIRA, Raimundo. Investigar faz parte do jornalismo. In: LOPES, Dirceu Fernandes; PROENÇA, José Luiz. (Orgs.) Jornalismo Investigativo. São Paulo: Publisher Brasil, 2003 , p. 27-41.

${ }^{241}$ MELO, José Marques de. A opinião no jornalismo brasileiro. Petrópolis: Vozes, 1985, p.63 e 66.

${ }^{242}$ PENA, Felipe. Teoria do jornalismo. 2 ed. São Paulo: Contexto, 2006, p. 201.

${ }^{243}$ FERRAZ JÚNIOR, Tércio Sampaio. Liberdade de opinião...cit, p. 25.

${ }^{244}$ Carlos A. Sortino, professor de "Periodismo de Investigación" da Universidad Nacional de La Plata, esclarece que, na Argentina, a Suprema Corte de Justiça passou a identificar o "periodismo de Investigación" como uma prática diversa do jornalismo diário, cotidiano, atribuindo àquele um maior grau de responsabilidade quando da valoração de causas por danos e prejuízos causados por erros informativos. Segundo seu relato, em um dos casos o Juiz Pettigiani distinguiu as "informações que resultam espontaneamente de fatos impactantes" daquelas provenientes do que se chama "jornalismo de investigação". Assim, para a Corte, "a responsabilidade emergente de um e outro caso deve analisar-se de distinta maneira, máxime quando a percepção do público é distinta, tratando-se de uma informação que por suas características intrínsecas apresenta uma maior margem de erro em relação à outra que se intui e apresenta como mais dotada de precisão, sendo também em razão de sua natureza e complexidade, habitualmente muito mais facilmente retificável a primeira que a segunda." Para o autor, "abre-se uma provável perspectiva jurisprudencial para demandas similares dirigidas contra relatos jornalísticos identificados como "Jornalismo 
Aliás, nesse modo de elaborar a notícia o profissional não é um "jornalista" no sentido etimológico do termo, o qual significa "analista de um dia", que verifica e noticia, de maneira quase instantânea, a ocorrência do fato. ${ }^{245}$ Sua atividade pode ser comparada a de um historiador ou até, de um investigador policial ao procurar descobrir os acontecimentos. $^{246}$

A base do jornalismo de investigação, portanto, não é a informação ou opinião sobre o fato que acabou de acontecer, mas deve ser uma pesquisa sólida, correta no procedimento, e dentro do limite de respeito aos direitos humanos, a ser realizada pelo repórter para descobrir os acontecimentos. Somente assim, a investigação jornalística é capaz de contribuir para o exercício de um governo democrático ${ }^{247}$, sobretudo quando a corrupção dentro de órgãos públicos e praticada por pessoas públicas tem sido o enfoque central do trabalho dessa imprensa, em todas as democracias ${ }^{248}$.

de Investigação", para que os magistrados endureçam suas posições e deixem de considerar escusáveis as informações inexatas, que não revistam o caráter de dolo". Cf. El periodismo de investigación, a juicio. Los imperdonables. In: Web para professionales de la comunicacion Iberoamericanos. n. 11. Año II, vol. 2, setembre 1999, p. 1. http://www. saladeprensa.org/art.htm. Acesso em 18 Jul. 2011.

${ }^{245}$ RAMONET, Ignacio. A tirania da comunicação. Trad. Lúcia Mathilde Endlich Orth. Petrópolis: Vozes, 1999, p. 74.

${ }^{246}$ Segundo Luís Guilherme Vieira, o jornalismo investigativo chega a ser confundido com a própria investigação policial, quando pretende que seus "achados" possam ser considerados provas. Cf. O fenômeno opressivo da mídia: uma abordagem acerca das provas ilícitas. Discursos sediciosos: crime, direito e sociedade. Rio de Janeiro: Freitas Bastos, 1998, p. 252.

${ }^{247}$ Sobre a investigação jornalística, menciona Luis Gustavo Grandinetti que é ela “... decorrência da cidadania em uma sociedade democrática, caracterizada pelo sistema representativo. Não podendo os cidadãos, por si, supervisionarem e fiscalizarem diretamente a administração pública, transferem, tacitamente, aos profissionais da informação esse seu direito de cidadania. Esses profissionais exercem a fiscalização dos órgãos públicos como mandatários dos cidadãos". Cf. Processo Penal e Constituição. Princípios constitucionais do processo penal. 4 ed. rev. atual., Rio de Janeiro: Lumen Juris, 2006, p. 247. No mesmo sentido é o entendimento de Dirceu Fernandes Lopes: "O Jornalismo Investigativo faz do seu trabalho o interesse dos cidadãos e, a partir deles, o papel que a imprensa tem nas sociedades democráticas. Ao denunciar a corrupção, as fraudes públicas e toda forma de atividade ilegal ou a má conduta em geral do poder, a imprensa se outorga a responsabilidade de servir de freio aos poderes políticos". Cf. Caminhos do jornalismo investigativo em busca da verdade oculta. Caminhos do jornalismo investigativo em busca da face oculta. In: LOPES, Dirceu Fernandes; PROENÇA, José Luiz. (Orgs.) Jornalismo Investigativo. São Paulo: Publisher Brasil, 2003, p. 15.

${ }^{248}$ Gerardo Albarrán de Alba anota que o jornalismo de investigação nos Estados Unidos da América está solidamente acreditado e reúne jornalistas em associações como Investigative Reporters and Editors (IRE). Cf. Diferencias em El periodismo de investigación em Estados Unidos y Latinoamérica. In: Web para professionales de la comunicacion Iberoamericanos. n. 32. Año III, vol. 2, junio 2001, p. 2. http://www. saladeprensa.org/art229.htm. Acesso em 18 Jul. 2011. Devemos anotar, também, que em outros países da América Latina trata-se de "atividade de risco" para os jornalistas, sendo que dezessete foram mortos somente entre 1999 e 2001, incluindo-se no Brasil, com o assassinato de Tim Lopes por integrantes do crime organizado do Rio de Janeiro, quando investigava o tráfico de drogas em favela daquela cidade. 
Todo jornalismo, portanto, implica investigação. Interessa-nos, sobretudo, o que se convencionou chamar de jornalismo investigativo, pela "técnica", pelo modo de realizá-lo, empregados pelo profissional dos meios de comunicação. Portanto, não é somente o conteúdo da matéria publicada que vai ter implicações na prova penal, mas também os métodos utilizados para buscar os fatos.

\subsection{A verdade jornalística}

"Antes de ser verdade jornalística, a verdade já há de ser verdade, simplesmente". ${ }^{249}$ Muito embora não encontremos clareza no conceito de verdade, o sentido de exatidão, de conformidade com o real que a palavra exprime, ampara-nos na tarefa de entendermos a "verdade jornalística".

A verdade é "a adequação ou conformidade entre o intelecto e a realidade. $\mathrm{O}$ intelecto é a inteligência, o entendimento, a razão, o conhecimento intelectual. A realidade é o ser. Na correspondência entre o intelecto e o ser firma-se a adequação de ideias constitutivas do objeto" 250 .

Essa relação de conformidade, correspondência a que nos remete o conceito mencionado, a que tem que existir entre o intelecto e o ser, ou daí derivando, a conformidade entre a situação factual e a expressão verdadeira apreendida pelo intelecto, é o que mais se aproxima da prática jornalística. ${ }^{251}$

Para dar início à construção da notícia, o jornalista, a partir de um fato, de um acontecimento, busca elementos para comprová-los. Assim, recolhe documentos, conversa

\footnotetext{
${ }^{249}$ SOUSA, Américo de. A retórica da verdade jornalística. In: http://www.bocc.ubi.pt/pag/sousa-americoretorica-verdade-jornalistica-pdf. Acesso em: 18 ago. 2011.

${ }^{250}$ BARROS, Marco Antonio de. A busca da verdade no processo penal. 2 ed. rev.atual. São Paulo: Revista dos Tribunais, 2010, p. 26.

${ }^{251}$ Esclarece José Arbex Jr., que "a ideia de que a notícia é o retrato do fato tal como ele realmente aconteceu não é nova. Ao contrário, é uma ideia que nasceu junto com a própria atividade jornalística, como sugerem os tradicionais jargões do tipo testemunha ocular dos fatos, a verdade dos fatos, doa a quem doer, jornalismo objetivo que leva os fatos até você e assim por diante. Em certo sentido, essa percepção da mídia como janela para o mundo ecoa a ideia da arte romântica do século I , quando a verdade da imagem dependia de seu grau de fidelidade à paisagem observada, ou do realismo, que pressupunha que o trabalho do artista deveria ser regido pela experiência direta da realidade, como condição para poder retratá-la ". Cf. Showrnalismo: a notícia como espetáculo. São Paulo: Casa Amarela, 2001, p. 104
} 
com pessoas ou testemunhas relacionadas ao objeto investigado - acontecimento, coisa ou pessoa - e, diante do apurado, elabora a reportagem, ou seja, o relato do fato.

Aqui, é preciso esclarecer que, se há um processo de elaboração da notícia e, se os elementos para formá-la são coletados das fontes, selecionados e interpretados, a verdade que se obtém não é a do fato, mas de sua versão. Todavia, ainda que um ponto de vista, unicamente do observador, seja utilizado para análise de um evento, a liberdade de alterar os fatos não existe. ${ }^{252}$ Portanto, quanto mais preciso o relato do fato, mais próximo estará de uma verdade capaz de ser apreendida pelo intelecto, não absoluta, mas um entendimento de uma verdade correta, elaborada com convicção de correspondência do ser.

Nossa percepção da verdade jornalística, no entanto, não corresponde, necessariamente, aos fatos como eles ocorreram, mas à expressão da "verdade" estampada no relato dos acontecimentos, que é elaborado pelos elementos colhidos na investigação ${ }^{253}$. Isso porque, os meios de comunicação, ao transmitir a notícia, tornam-na impactante no sentido de impô-la como verdade absoluta, e os fatos, para os destinatários da informação, são verdadeiros porque a mídia assim os divulgou.

Uma aproximação dos fatos, como realmente são ou ocorreram, deve ser a tônica do trabalho da imprensa. ${ }^{254}$ É necessária uma apuração bem feita, pois o resultado do trabalho de investigação da mídia não pode decorrer da imaginação do profissional, mas as notícias publicadas devem ser destinadas à transmissão da verdade ${ }^{255}$. E é a busca da verdade, mister insistir, o objeto primordial do jornalismo investigativo. ${ }^{256}$

\footnotetext{
${ }^{252}$ ARBEX JR., José. Showrnalismo...cit., p. 108.

${ }^{253}$ COUTINHO, Iluska. O conceito de verdade e sua utilização no jornalismo. Revista Acadêmica do Grupo Comunicacional de São Bernardo, ano 1, n. 1, janeiro-junho de 2004, p. $14 . \quad$ In: http://www2.metodista/unesco/GCSB/conceito.pdf. Acesso em: 15 ago. 2011.

${ }^{254}$ Darlete Cardoso entende que, justamente porque a informação é a realidade interpretada, reflete só um aspecto da realidade, porque existe a limitação investigativa do jornalista que não consegue juntar todas as partes dos fatos, é impossível falar-se em "verdade" da informação. Cf. A objetividade jornalística é (im)possivel? O discurso e seus efeitos. http://www.discurso.ufrgs.br/sead2/doc/discurso/darlete.pdf. Acesso em: 12 maio 2011.

${ }^{255}$ NUVOLONE, Pietro. Il diritto penale della stampa. Padova: CEDAM, 1971, p. 54.

${ }^{256}$ KOVACH, Bill, ROSENSTIEL, Tom. Os elementos do jornalismo. O que os jornalistas devem saber e o público deve exigir. Tradução de Wladir Dupont. 2 ed.. São Paulo: Geração Editorial, 2004, p. 61.
} 
A noção de "verdade jornalística" não pressupõe que seja ela inatacável, absoluta, mas que haja uma crença, uma convicção de que a narrativa corresponde, o mais próximo possível, à realidade dos fatos. Portanto, essa forma "prática e funcional da verdade" 257 é o objetivo do jornalismo de investigação.

Essa meta da verdade a ser alcançada pelo jornalismo, só se concebe, no entanto, se for "gerada na diversidade de fontes, de narradores, de veículos, de públicos e, sobretudo, de instituições (públicas ou privadas) dedicadas ao negócio de informar o cidadão". 258

Além disso, também devem ser proporcionadas ao leitor várias versões fornecidas pelas fontes, para que forme a sua convicção sobre os fatos. Essa pluralidade de relatos, feitos com exatidão, é mais um elemento agregador da função pública da mídia, porque fortalece a pluralidade de opiniões, essencial numa democracia.

A verdade buscada pela mídia, portanto, é aquela cujos acontecimentos, o jornalista acredita estarem "provados". Além disso, à verdade como objetivo soma-se o objetivo da verdade: a convicção do leitor, a informação da opinião pública e a credibilidade do meio informativo $^{259}$. E para esse fim, a investigação exaustiva dos fatos, além de desnecessária, é impossível de ser alcançada, principalmente porque a notícia deve ser divulgada, e o tempo despendido numa busca incessante da comprovação dos acontecimentos prejudicaria a atualidade da informação. Daí ser a verdade jornalística, aquela suficiente para convencer o público.

Aliás, nesse sentido já se pronunciou o Tribunal de Justiça de São Paulo, no caso conhecido como "Operação Satiagrara", valendo transcrever: "A imprensa existe para esclarecer a opinião pública, e a dinâmica dos acontecimentos não autoriza que o leitor seja

${ }^{257}$ KOVACH, Bill. ROSENSTIEL, Tom. Os elementos do jornalismo...cit., p. 68.

${ }^{258}$ BUCCI, Eugênio. A imprensa e o dever da liberdade. São Paulo: Contexto, 2009, p. 81. Outra questão considerada pelos autores, importante mencionarmos, é que, a verdade jornalística, digna de ser acreditada, que contribui para a eficácia do direito à informação, é de difícil possibilidade prática, se o receptor da notícia não dispõe de critérios variados de avaliação e, nem tampouco multiplicidade de meios de comunicação para confrontá-la. Logo, segundo Ignacio Ramonet, “se todos dizem a mesma coisa, é obrigado a admitir que é a versão correta dos fatos, a notícia verdade oficial”. Cf. A tirania...cit., p. 62. No mesmo sentido, CARVALHO, Luis Gustavo Grandinetti de. Direito de informação e liberdade de expressão. Rio de Janeiro: RENOVAR, 1999, pp. 159-160.

${ }^{259}$ No que respeita à credibilidade do meio informativo, Bill ovach e Tom Tosentiel dizem que "Na vida real, as pessoas sempre sabem quando alguém chegou perto da verdade, quando a fonte é autorizada, quando a pesquisa é exaustiva, quando o método é transparente". Cf. Os elementos do jornalismo...cit., p. 75. 
informado com o resultado tomado após longa e exaustiva investigação da verdade do fato publicado. Caso fosse exigir o rigor probatório que modela a persecução criminal para liberar a edição, a demora da pesquisa esvaziaria o produto social que é indispensável para o exercício da democracia, qual seja, a própria reportagem bombástica [...] ”. ${ }^{260}$

Para fins do nosso estudo, interessa-nos, sobretudo, a verdade buscada na diversidade de fontes, pois nessas constrói-se a informação que se aproximará da realidade fática.

Além disso, se o objetivo do jornalismo investigativo é revelar a verdade de um acontecimento de interesse público, os métodos para buscá-la, colher as "provas" dos fatos, exigem do jornalista correção no desenvolvimento do processo informativo, O caminho da investigação dos acontecimentos não pode ser percorrido senão dentro de limites éticos, legais e com respeito aos direitos fundamentais do ser humano.

Ainda que a correção procedimental seja insuficiente para a descoberta da mais completa verdade, é a maneira pela qual entendemos possível a mídia atingir sua função pública de bem informar.

Para Matthew Kieran, ${ }^{261}$, esse é o modo de se fazer um jornalismo investigativo de qualidade. Para ele, a revelação da verdade de um assunto de interesse público exige dos jornalistas que os "métodos de adesão à verdade" sejam sérios. Finalmente, ele considera uma "falha moral", absolutamente reprovável, a conduta negligente do profissional na

\footnotetext{
${ }^{260}$ Acórdão Apelação n. 0159459-20.2009.8.26.0100, Relator Desembargador Enio Zuliani, $4{ }^{a}$ Cam. Direito Privado, v.u., 07 de julho de 2011. No caso citado, a Revista ISTO É, em reportagem, publicou que o Delegado Protógenes, da Operação Satiagrara, entregou fita de vídeo ao Procurador da República, na qual apareciam filmados dois assessores do Ministro Gilmar Mendes, que concedeu a liminar no habeas corpus impetrado em favor de Daniel Dantas, em restaurante em Brasília, com o advogado do banqueiro, quando se captou trecho de uma expressão da conversa ("um milhão de dólares"). Posteriormente, como a Abin não confirmou a realização da gravação mencionada e, posteriormente, verificou-se que os fatos alardeados na publicação - levantando a suspeita de ter ocorrido manipulação fraudulenta para a obtenção de liminar no STF - eram inverídicos, a Revista ISTO confirmou que o episódio foi "uma farsa engedrada por encarregados da investigação". Daí a razão pela qual o Tribunal de Justiça entendeu que não obstante a Revista ISTO É tenha cumprido sua função de reportagem investigativa, no momento da publicação deve haver "um mínimo de dado confiável sobre a credibilidade do que seria publicado". A Revista foi condenada por danos morais em $\mathrm{R} \$ 75.000,00$.

${ }^{261}$ Cf. Estrutura ética e regulatória do jornalismo investigativo. BURGH, Hugo de. (Org.) Jornalismo investigativo: contexto e prática. Trad. Luiza Lusvarghi. São Paulo:Roca, 2008, p. 174.
} 
inobservância das regras éticas e legais, pois essa função exige responsabilidades que lhe são inerentes, além de postura com aquela compatível.

\subsection{Busca da verdade: acesso às fontes de informação}

O direito a informar-se, como "conteúdo reflexo que protege a própria atividade do comunicador social" ${ }^{262}$, contém uma vertente positiva, a qual consiste no livre acesso às fontes de informações, e outra negativa, que é a proteção do segredo delas. ${ }^{263}$

A atividade de aceder à origem dos fatos noticiosos, a aquisição do conhecimento para posterior publicação, é um “comportamento instrumentalmente necessário" 264 voltado para a ação informativa. $\mathrm{O}$ direito de informar, que abrange todo o processo informativo desde a obtenção e elaboração da notícia, até sua difusão, só pode ser efetivado com o acesso às fontes pelos jornalistas. ${ }^{265}$

Fonte é "local de onde vem ou onde se produz algo; procedência, origem, proveniência", mas é também "pessoa que fornece informações secretas ou privilegiadas, especialmente à imprensa",266.

Qualquer objeto, documento, situação ou acontecimento, ou toda pessoa, física ou jurídica, que relate, forneça informações ao jornalista, pode ser considerado "fonte", de onde procede a notícia que vai ensejar, ou não, a investigação dos fatos para compor a elaboração da reportagem. ${ }^{267}$

\footnotetext{
${ }^{262}$ EKMEKDJIAN, Miguel Ángel. Derecho a la información. Reforma constitucional y libertad de expresión. Nuevos aspectos. 2 ed., Buenos Aires: Depalma, 1996, p. 61.

${ }^{263}$ EKMEKDJIAN, Miguel Ángel. Derecho a la información...cit. p. 61.

${ }^{264}$ ZACCARIA, Roberto. Diritto dell'informazione e della comunicazione. 4 ed., Milano: CEDAM, 2003, p. 49.

${ }^{265}$ Consta na Declaração de direitos e deveres dos jornalistas de Munich de 1971: "Os jornalistas reivindicam o livre acesso a todas as fontes de informação e o direito de pesquisar livremente sobre todos os fatos que condicionam a vida pública. O segredo dos trabalhos públicos e privados não podem ser opostos ao jornalista, a não ser por exceção, em virtude de motivos claramente expressos". Cf. GUEDJ, M. Alexis. Liberté et responsabilités...cit., p. 146, nota 1.

${ }^{266}$ Conceito fornecido por HOUASISS, Antônio; VILLAR, Mauro de Salles e MELLO FRANCO, Francisco Manoel de. Dicionário Houaiss da língua portuguesa. Rio de Janeiro: Objetiva, 2001, p. 1369.

${ }^{267}$ Segundo Jónatas E. M. Machado, "o termo fontes refere tudo o que seja portador de informação, quer se trate de pessoas ou de objetos. Fontes de informação tanto podem ser, por exemplo, documentos, livros, ficheiros informáticos ou filmes, como um titular de um cargo público, um homem da rua ou mesmo a
} 
Sempre localizado e, como elemento da liberdade de expressão e informação, o livre acesso às fontes obteve um reconhecimento expresso na Constituição brasileira, com a incorporação do Pacto de São José da Costa Rica ${ }^{268}$, em cujo art. 13, 1 consta que a liberdade de expressão "compreende a liberdade de buscar, receber e difundir informação [...] sem consideração de fronteiras".

Podemos dizer, então, que o aspecto positivo do direito a informar-se, com o livre acesso às fontes, é norma que, no sistema jurídico brasileiro não somente decorre da ampla liberdade de informação, mas inclusive, é assegurada expressamente e, como tal, deve ser exigida pelo público e cumprida por todas as esferas do Poder.

\subsection{Fontes públicas}

Em geral, as fontes mais abundantes de informações que a mídia possui, são as públicas. ${ }^{269}$ Nos órgãos estatais, nas empresas e organizações públicas e privadas, encontram-se os dados referentes à formação e funcionamento da estrutura da sociedade.

Hoje, o jornalismo investigativo busca nas fontes oficiais, como os órgãos administrativos, o Poder Judiciário, a Polícia, o Poder Legislativo, as informações consideradas de interesse social, pois são entendidas como sérias e confiáveis. ${ }^{270}$ Para a imprensa, há uma presunção de veracidade nas informações das fontes oficiais, o que

opinião pública". Cf. Liberdade... cit., p. 480. No conceito de "fontes", Miguel Ángel E me djian entende aquela que permite informar-se não só aos jornalistas, como um documento, a pessoa informante, mas também à opinião pública. Assim, a televisão, um jornal, um planfeto, também são fontes de informações. Cf. Derecho a la información...cit., p.62.

${ }^{268}$ O Brasil subscreveu o texto da Convenção Americana de Direitos Humanos, o qual foi aprovado por meio do Decreto Legislativo 27, de 26.05.1992. Com a promulgação em 06.11.1992, o texto legal integrou o ordenamento jurídico brasileiro. Portanto, conforme enfatiza Luis Flávio Gomes, "particular atenção ela deve merecer dos juristas, os quais se encarregarão de sua compatibilização com os textos internos, bem como dos Juízes e Tribunais". Cf. A questão da obrigatoriedade dos tratados e convenções no Brasil: particular enfoque da Convenção Americana sobre Direitos Humanos. RT, vol. 710, p. 30, dez. 1994.

${ }^{269}$ Sobre o direito de acesso à informação pública, esclarece Marcela I. Basterra que ele “ ... se exerce como direito individual quando uma pessoa solicita informação ou dados acerca de si mesma, de uma base de dados ou registros de qualquer dependência estatal. [...] é um direito coletivo porque o bem requerido é um bem coletivo, a informação estatal ". Cf. El derecho fundamental de acceso a la información pública. Buenos Aires: Lexis Nexis, 2006, p. 37.

${ }^{270}$ Segundo Nilson Lage, não é possível considerar verídicas, confiáveis e imparciais, as informações de fontes oficiais, pois os dados por elas fornecidos, por vezes, correspondem à realidade do que lhes é conveniente tornar público. Cf. A reportagem: teoria e técnica de entrevista e pesquisa jornalistica. Rio de Janeiro: Renovar, 2001, p. 63. 
legitima sua atividade, sobretudo em razão do dever de diligência que possui, o qual estaria cumprido.

A informação considerada pública é aquela cujas entidades do setor público do Estado detêm e, em princípio, reveste o caráter de ampla publicidade nas sociedades modernas, o que permite às pessoas conhecer e controlar a atuação estatal.

Não é demais afirmarmos que a necessidade de transparência dos atos governamentais é essencial para a participação cidadã nas questões públicas, o que se realiza com o acesso às informações, como uma maneira de o Estado se relacionar com as pessoas. Aqui vige o princípio da "administração aberta"271 da atividade governamental, no pressuposto de que "não pode existir autogoverno sem acesso à informação de Governo". ${ }^{272}$ O princípio da publicidade da administração pública, secundada pelo legislador constituinte, garante não apenas o regular desenvolvimento do Estado, mas também garante e reflete em outras estruturas sociais, pois é extremamente ampla e, de suma relevância, as informações que a Administração possui acerca dos indivíduos e de todas as entidades públicas e privadas, como complexo organizacional da sociedade. ${ }^{273}$

Para a difusão dos atos estatais, através dos meios de comunicação, não pode haver obstáculos além daqueles que a lei considere estritamente necessários, por questões amparadas constitucionalmente. Resulta da liberdade de imprensa, segundo a doutrina, um direito legítimo de obter informações junto aos órgãos e autoridades públicas, o que vem assegurado no artigo 4 do Código de tica dos Jornalistas Brasileiros: "A apresentação de informações pelas instituições públicas, privadas e particulares, cujas atividades produzam efeito na vida em sociedade, é uma obrigação social".

Aliás, muito mais do que uma atitude passiva por parte do Estado, de não impedir o acesso às informações públicas, um país considerado democrático deve propiciar e facilitar

\footnotetext{
271 Sobre o princípio da administração aberta, ver CANOTILHO, J.J. Gomes; MOREIRA, Vital. Constituição da República Portuguesa anotada, 3 ed., Lisboa, 1993, p. 934-935.

${ }^{272}$ MACHADO, Jónatas E. M. Liberdade...cit., p. 555. Esclarece o autor, ainda, que "numa ordem constitucional democrática, a informação detida pela Administração é entendida como pública, e não como oficial, significando isso que a mesma foi gerada ao serviço dos cidadãos, pertencendo-lhes em via de princípio ...”. (p. 555).

${ }^{273}$ MACHADO, Jónatas E. M. Liberdade...cit., p. 555.
} 
a busca de informações em órgãos oficiais. ${ }^{274}$ Os E.U.A., como exemplo ${ }^{275}$, possui o expedited processing, que outorga aos meios de comunicação um prazo inferior para receber documentações solicitadas, pois destinados à divulgação da atividade governamental. ${ }^{276}$

$\mathrm{Na}$ Constituição brasileira, consagrado como direito fundamental no art. $5^{\circ}$, XXXIII, "todos têm direito a receber dos órgãos públicos informações de seu interesse particular, ou de interesse coletivo ou geral, que serão prestadas no prazo da lei, sob pena de responsabilidade, ressalvadas aquelas cujo sigilo seja imprescindível à segurança da sociedade e do Estado". Ora, nos termos expressos pelo legislador constituinte, não só os cidadãos, individualmente, mas também a imprensa possuem legitimidade ativa para solicitar informações junto aos órgãos públicos, o que decorre, inclusive, da ampla liberdade de acesso às fontes, previsto no art. $5^{\circ}$, XIV.

A Lei Federal 8.159, de 08.01.1991, com o escopo regulamentador do direito fundamental mencionado, na realidade dispôs sobre a política nacional de arquivos públicos e privados, detendo-se de maneira tímida, no entanto, à questão referente ao acesso e sigilo dos documentos públicos.

Com a Lei 11.111 de 05.05.2005, foi normatizada a parte final do inciso XXXIII do art. $5^{\circ}$, da Constituição Federal, em cujo artigo 2 consta que "o acesso aos documentos públicos de interesse particular ou de interesse coletivo em geral será ressalvado,

274 O Jornal Folha de São Paulo começou a divulgar, em 28 de agosto de 2011, o teor dos telegramas confidenciais - 10.883 páginas sigilosas - do período 1990-2001, liberados pelo Itamaraty a pedido dos repórteres. Segundo reportagem, "Em nota, o Itamaraty informou que a orientação é, seguindo a legislação sobre o assunto, dar a maior transparência possível aos documentos gerados pelo ministério e à política externa . Cf. EUA elogiam o Itamaraty pela liberação de documentos à Folha. Folha de São Paulo, 30 de agosto de 2011, p. A14, mundo.

${ }_{275}$ Sobre o acesso às informações públicas, nos diversos países das Américas, importante a análise feita por Marcela I. Basterra, na obra El derecho fundamental de acceso a la información pública, já citada.

${ }^{276}$ COBO, Dolores Lavalle. Derecho a la información pública. Buenos Aires: Astrea, 2009, p. 56. A autora, na nota 44, cita o Caso "The Washington Post v. Department of Homeland Security", 2006, US Dis. Lexis 75716, no qual o jornal “ The Washington Post'" solicitou ao Serviço Secreto dos Estados Unidos da América (uma divisão pertencente ao Departmente of Homeland Security) uma listagem com os registros de pessoas que visitaram o vice-presidente Dick Cheney e seu staff mais importante em seu escritório da Casa Branca e em sua residência. O demandante alegou que qualquer demora no processamento da solicitação poderia privar o público da sua capacidade de formar sua própria opinião em tempo oportuno. O tribunal concedeu um mandado judicial preliminar (preliminary injunction) para que a demandada entregasse a informação dentro de dez dias". 
exclusivamente, nas hipóteses em que o sigilo seja ou permaneça imprescindível à segurança da sociedade e do Estado [...]".

Vê-se, pois, que a legislação nacional, até então, não trazia clareza nas regras para abertura e divulgação de documentos sigilosos no Brasil. A Lei n. 12.527, de 18 de novembro de 2011, no entanto, que "regula o acesso a informações previsto no inciso XXXIII do art. $5^{\circ}$, no inciso II do $\S 3^{\circ}$ do art. 37 e no $\S 2^{\circ}$ do art. 216 da Constituição Federal" 277 é mais consentânea com o princípio democrático que norteia a Carta de 88 , na qual a observância da publicidade é a regra e o sigilo, a exceção.

No novo texto legislativo pouca margem de discricionariedade (ou arbitrariedade) restou ao Estado para dizer quais documentos devem ser mantidos sob segredo, vedados ao acesso e à divulgação pelos meios de comunicação ou, de outro modo, levado a conhecimento público. As restrições de acesso foram elencadas, e classificadas as informações quanto ao grau e prazos de sigilo, não podendo ultrapassar vinte e cinco anos o segredo dos dados ultrassecretos. Essa, portanto, uma das relevantes alterações contidas na nova lei, cujo escopo é assegurar o direito fndamental de acesso à informação (art. $3^{\circ}$ ).

\subsubsection{Segredo de Estado como limite - noções gerais}

Em princípio, vislumbra-se paradoxal afirmarmos que uma espécie de segredo utilizado por regimes ditatoriais, de cunho autoritário, encontre lugar no Estado Democrático de Direito, cuja regra é a transparência das informações. Todavia, nos Estados democráticos desenvolvidos, a liberdade de informação é protegida e, em casos restritos, algumas notícias não estão disponíveis ao conhecimento público ${ }^{278}$.

Disse Norberto Bobbio que a meta da democracia como poder absolutamente transparente, completo, para todos, é inatingível. O poder traz na sua essência a ocultação,

\footnotetext{
${ }^{277}$ Preâmbulo da Lei n. 12.527/2011, que alterou a Lei 8.112/90 e revogou a Lei 11.111/2005 e dispositivos da Lei 8.159/91.

${ }^{278}$ GOUVEIA, Jorge Bacelar. Segredo de Estado. Disponível em www.estig.ipebeja.pt/ ac_direito/BGSefredo.pdf. Acesso: 05 de maio 2010.
} 
o que não significa ser a distinção entre poder visível e poder invisível, critério para caracterizar a diferença entre governo democrático e autocrático. ${ }^{279}$

Todos os países sentiram necessidade de garantir segredos, através de medidas jurídicas e regulamentares, contra todas as formas de ameaças internas ou externas. ${ }^{280}$ Assim, uma vez que é necessária a convivência entre a publicidade e o segredo dos atos governamentais, pois não constituem princípios absolutos, é preciso buscar soluções para que o segredo de Estado não se torne escudo para interesses políticos inescrupulosos, que se distanciem do fim constitucional da reserva de informação.

A recolha de informações nas fontes públicas, assim como a liberdade de imprensa, encontra limites em outros direitos como os da personalidade do indivíduo, no bom funcionamento da justiça e das instituições e no segredo de Estado. A restrição do público em geral e do acesso dos jornalistas às informações, é o modo de preservação de outros valores que existem no Estado de Direito.

O segredo de Estado é um dos limites de acesso à informação pelos meios de comunicação de massa, bem como pelo público. A necessidade de garantia de uma esfera de segredo da instituição "Estado" diz respeito à proteção da segurança ${ }^{281}$ nacional, entendendo-se essa como um conjunto de condições básicas de defesa e estabilidade da paz e da democracia numa ordem política livre.

A interpretação de segurança nacional, compatível com a Constituição, é a de meios para subsistência do sistema democrático, com o fïm de proteção dos direitos fundamentais dos cidadãos, o que pressupõe, também, o resguardo do Estado na sua dimensão territorial, da ordem interna e uma correta condução da política externa da Nação. ${ }^{282}$ A segurança nacional $^{283}$, portanto, fundamenta a restrição de acesso a alguns documentos e informações através da imposição a esses, excepcionalmente, do segredo.

\footnotetext{
${ }^{279}$ BOBBIO, Norberto. Teoria geral da política. Rio de Janeiro:Campus, 2000, p. 389.

${ }^{280}$ ROBERT, Jacques. Le secret défense. Secret et démocratie. Paris, 1997, p. 21.

281 Para José Afonso da Silva, "Na teoria jurídica a palavra segurança assume o sentido geral de garantia, proteção, estabilidade de situação ou pessoa em vários campos, dependente do adjetivo que o qualifica". Cf. Curso de Direito Constitucional...cit. p. 777.

${ }^{282}$ MACHADO, Jónatas E. M. Liberdade...cit., p. 860.

${ }^{283}$ Art. 23, I da Lei n. 12.527/2011.
} 
O sentido de segredo de Estado, como dimensão do valor da segurança nacional, vem expresso no artigo 256 do Código Penal italiano, segundo o qual "a notícia que, no interesse da segurança do Estado ou em seu interesse político, interno ou internacional, deve permanecer em segredo [...] as notícias que devem permanecer secretas, no interesse político do Estado são aquelas contidas em atos do Governo, não publicadas por razões de ordem política, interna ou internacional”. A norma, aliás, limita o acesso à notícia que deve permanecer em segredo e, o artigo 261 pune a revelação dos segredos de Estado.

Na legislação italiana, o segredo de Estado abrange "os atos, os documentos, a notícia, a atividade e cada outra coisa cuja difusão seja idônea a causar dano à integridade da República, também em relação a acordos internacionais, à defesa das instituições consideradas fundamentais pela Constituição, à independência do Estado perante outros Estados e às relações com estes, à preparação e à defesa militar do Estado". 284

Em Portugal, a Lei 6, de 1994, tratou do segredo de Estado e, no seu artigo 2º I, disse que "são abrangidos pelo segredo de estado os documentos e informações cujo conhecimento por pessoas não autorizadas é susceptível de por em risco ou causar dano à independência nacional, à unidade e integralidade do Estado e à sua segurança interna e externa".

Denota-se, pois, uma grande dificuldade doutrinária e legislativa em definir segredo de Estado, generalizando-se a ideia de tratar-se de um "conhecimento ou informação que o Estado mantém voluntariamente oculto para garantir proteger a segurança nacional"285, atribuindo-se ao termo o sentido, o escopo, o objeto que deve permanecer secreto.

Antes de entender o sentido do termo, as fontes latinas trazem um conceito de segredo de Estado. De arcana imperii e secreta imperii, possui o significado de poder político supremo que deve ser ocultado, fechado, limitado (arcanum). Arcanum e secretum coincidem no significado: ambos fazem referência a "qualquer coisa que deva permanecer

\footnotetext{
${ }^{284}$ Art. 39, I da Lei n. 124 de 3 de agosto de 2007.

285 ARENAZA, Iñigo Segrelles de. El secreto de Estado ilegal: Aspectos básicos. Cuadernos de política criminal. Madrid: Edersa, n. 62, 1997, p. 419.
} 
obscuro da maioria dos homens e conhecido somente à determinada pessoa, sobre a qual grava a obrigação de manter o segredo, de servare secretum. ${ }^{286}$

A Lei de Imprensa ${ }^{287}$, no art. 15 prevê serem típicas as figuras de "publicar ou divulgar: a) segredo de Estado (...) b) notícia ou informação sigilosa, de interesse da segurança nacional (...)”. Portanto, se não há, em princípio, palavras inúteis na lei, segredo de Estado é coisa diversa de segurança nacional, mas muitas vezes os termos são utilizados, equivocadamente, com o mesmo sentido.

Coube à Lei 7.170, de 14 de dezembro de 1983, restringir o conceito de segurança nacional, como sendo "o que se refere à nação como um todo, e diz respeito à própria existência do Estado e à sua independência e soberania. Trata-se de segurança nacional, ou seja, da nação. Ela não se confunde com a segurança do governo, ou da ordem política e social, que é coisa bem diversa". ${ }^{288}$

Os segredos de Estado, de natureza processual, porque visam a impedir a divulgação de informações confidenciais ${ }^{289}$ são, na verdade, categorias de "segredos públicos" ${ }^{290}$ que decorrem de uma "escolha operada por parte de quem (sujeito institucional) detém uma determinada informação, escolha de determinação de garantir a reserva e, portanto, de preparar os instrumentos previstos pelo ordenamento para impedir o acesso àqueles que não estão em condições jurídicas de poder a eles, legitimamente, aceder". 291

${ }^{286}$ SCANDONE, Giuseppe. Il segreto di stato come species del genus segreto. Definizione. MOSCA, Carlo; SCANDONE, Giuseppe; GAMBACURTA, Stefano; VALENTINO, Marco. (Coords.) In: I servizi di informazione e il segreto di stato. (Legge 3 agosto 2007, n. 124). Milano: Giuffrè, 2008, p. 463.

${ }^{287}$ Lei 5.250/67

${ }^{288}$ FRAGOSO, Heleno Cláudio. A nova Lei de Segurança Nacional. Disponível em: http://www.fragoso.com.br/eng/arq...pdf/heleno_artigos/arquivo32.pdf. Acesso em 31 de agosto de 2011. Sobre o conceito de segurança nacional, Dolores Lavalle Cobo, diz que a denominação se transformou, nas últimas décadas, diante da necessidade de dar ao termo maior alcance, devido "a outra classe de ameaças que podem pôr em risco a estabilidade de um regime democrático, entre as que se pode mencionar: o contrabando de armas, a guerra tecnológica, o narcotráfico, a instalação de armas atômicas etc., perigos que transcendem as fronteiras de um país, para o qual pode ter impacto na vida interna e cotidiana dos cidadãos de outra nação." Cf. Derecho de acceso...cit., p. 229.

${ }^{289}$ CHIAVARIO, Mario. Segreto di Stato e giustizia penale. Bologna: Zanichelli, 1978, p. 5.

${ }^{290}$ PISA, Paolo. Il segreto di stato. Milano: Giuffrè, 1977, p. 2

${ }^{291}$ SCANDONE, Giuseppe. Il segreto di stato come species del genus segreto. Definizione. MOSCA, Carlo; SCANDONE, Giuseppe; GAMBACURTA, Stefano; VALENTINO, Marco. (Coords.) In: I servizi di informazione e il segreto di stato. (Legge 3 agosto 2007, n. 124). Milano: Giuffrè, 2008, p. 445. 
O problema está, exatamente, na "escolha" dos atos ou informações que devem permanecer reservadas apenas às altas autoridades do Estado ${ }^{292}$. Há uma inevitável compressão do direito à liberdade de informar-se e o fundamento do segredo, que salvaguarda bens jurídicos próprios, deve encontrar amparo constitucional.

Restringimos o nosso estudo acerca do segredo de Estado, apenas no que diz respeito à dimensão do limite ao acesso às informações pela mídia.

Ao contrário do sistema jurídico italiano, o qual prevê, normativamente, o que deva ser considerado segredo de Estado relevante, e pune as condutas de procurar, receber ou difundir informações protegidas sob aquela reserva ${ }^{293}$, no Brasil ainda é incipiente o desenvolvimento legislativo e doutrinário sobre o tema.

Não há menção legal expressa sobre qual informação deve ser secreta, de impossibilidade de acesso, porque "imprescindivel à segurança da sociedade e do Estado" (art. 5, XXXIII da CF 88). Ou seja, não há definição sobre qual informação não pode ser divulgada porque considerada "segredo de Estado".

Há entendimento no sentido de que seriam as informações capazes de causar “danos diretos, imediatos e irreparáveis ao Estado e à comunidade política" ${ }^{294}$, ou os "atos, fatos e coisas, cuja revelação possa pôr em perigo a estabilidade estatal"295, circunscrevendo-se ao denominado segredo de Estado.

\footnotetext{
${ }^{292}$ Francisco Bilac M. Pinto Filho faz a distinção entre documento ou informação pública strictu sensu e o documento ou informação pública de relevância pública, que é o formalmente público, mas de conteúdo particular. Para ele, o primeiro é público na essência e pode ter conteúdo que implique a segurança estatal. A sua revelação cabe aos agentes públicos. O segundo, cujas informações foram fornecidas pelo particular, adquirem forma pública e estão sob a custódia da Administração Pública e o acesso a eles independe da Administração. Assim sendo, esclarece o autor, "todos os dados, independente da produção ou origem dos mesmos (pública ou particular, que tenham relevância para a segurança do Estado ou da sociedade, são documentos ou informações de conteúdo público e podem ter sua divulgação obstada. São aqueles que, mesmo tendo origem particular, não tenham apenas um valor histórico, científico ou informativo, e têm, em verdade um valor de segurança estatal ou social que demandará das autoridades a declaração de que se tratam de documentos de conteúdo público, apesar da origem particular, cujo acesso pode ser obstado, a critério do agente público responsável pela guarda do documento ou informação". Cf. O segredo de Estado e as limitações ao habeas data. Revista dos Tribunais. Fasc. Civ., Ano 91, v. 805, nov. 2002, pp. 47-48.

${ }^{293}$ Lei 801 de 24 de outubro de 1977 e artigo 256 do Código Penal italiano, respectivamente.

${ }^{294}$ MACHADO, Jónatas J. J. Liberdade...cit., p. 863.

${ }^{295}$ MIRANDA, Darcy Arruda. Comentários à lei de imprensa. $2^{\mathrm{a}}$ ed., rev. atual. Tomo I, São Paulo: Revista dos Tribunais, 1994, p. 170.
} 
A Constituição Federal afirma, no entanto, que para haver sigilo é necessário que seja ele "imprescindível" à segurança da sociedade e do Estado. Então, não basta sua utilidade, mas deve ser indispensável, cabendo aos órgãos públicos que detêm as informações sigilosas o ônus de comprovar, motivadamente, a absoluta necessidade da manutenção do caráter sigiloso do documento. ${ }^{296}$

Há em vigor, no Brasil, o Dec. 5.301/2004 ${ }^{297}$, cujo artigo $5^{\circ}$ classificou os documentos sigilosos em ultrassecretos, secretos, confidenciais ou reservados como, por exemplo, e respectivamente: os dados ou informações referentes à soberania e à integridade territorial nacionais; assuntos diplomáticos; assuntos de interesse do Poder Executivo cuja revelação não autorizada possa acarretar dano à segurança da sociedade e do Estado; informações ou dados cuja revelação possa comprometer operações neles previstos.

A Lei 12.527/2011, por sua vez, dispõe que o “interesse público da informação” é o critério a ser observado para classificar o grau de sigilo, devendo ser considerado " $a$ gravidade do risco ou dano à segurança da sociedade e do Estado" (art. 24, § 5, I).

Até certo ponto, a classificação dos documentos sigilosos delimita o âmbito de atuação da Administração Pública que não parece poder ampliar a relação ali exposta, porque se trata de restrição ao princípio da publicidade que rege seus atos. ${ }^{298}$ Todavia, não é possível definir quais deles podem ser considerados segredo de Estado para fins de restrição de acesso à imprensa. Será que o sigilo justifica-se em qualquer assunto diplomático e pode impor-se como barreira ao conhecimento público, através dos meios de comunicação de massa? Não nos parece razoável.

$\mathrm{O}$ acesso às fontes de informações públicas, pela imprensa, deve ser livre. O limite em razão de segredo de Estado só é aceitável se houver lei que regule, defina-o e identifique os segredos de forma clara, sem margem às interpretações extensivas. É o teor

${ }^{296}$ MACHADO, Paulo Afonso Leme. Direito à informação e meio ambiente. São Paulo: Malheiros, 2006, p. 241.

${ }^{297}$ Pouco alterou o Decreto 4.553/2002, o qual, nos artigos $5^{\circ}$ e $7^{\circ}$, classificou os dados ou informações sigilosos em ultra-secretos, secretos, confidenciais e reservados, além de fixar prazos de duração.

${ }^{298}$ Paulo Afonso Leme Machado questiona a constitucionalidade do Decreto. Cf. Direito à informação... cit., p. 242 e sgts. 
do Princípio 1 de Johannesburgo: "Qualquer restrição trazida à expressão ou à informação deve ser prevista pela lei. A lei deve ser acessivel, sem ambigüidades, escrita de modo preciso e com limites, de modo a permitir aos indivíduos saber se uma determinada ação é ilegal". 299

A definição legal, precisa e mais clara possível a essa exceção à publicidade dos atos governamentais, impedirá que os critérios sejam fixados pelos Poderes Executivo e Judiciário. Nesse sentido, é o entendimento de Freitas Nobre. Ao comentar o crime de divulgação de segredo de Estado, previsto no art. 15 da Lei de Imprensa, foi enfático ao afirmar que, sem a existência de norma especificando o segredo, a confidência ou reserva, o jornalista não pode ser responsabilizado por abuso da informação, sendo inadmissível, inclusive, atribuir ao julgador o significado casuístico de segredo de Estado ou "interesse da segurança nacional". 300

Por conseguinte, não obstante reste bastante impreciso o significado de segredo de Estado, em nome da segurança nacional não se autoriza sua invocação abusiva para impedir a divulgação das notícias de relevante interesse público, criando obstáculos à imprensa, em afronta a princípios constitucionais, no acesso a documentos e informações acerca da atuação dos Poderes da República.

Não basta, pois, alegar o segredo de Estado como pressuposto da segurança nacional, para que este bem jurídico prevaleça sobre qualquer outro valor constitucional, sobretudo a liberdade de imprensa. Deve haver fundamento legal e justificação para a exceção à publicidade. Isso porque, é imprescindível que, nas democracias, o recurso ao segredo decorra de uma atividade regrada, a qual deve considerar a excepcionalidade e a necessidade de limite temporal. ${ }^{301}$

\footnotetext{
${ }^{299}$ Tradução feita por Paulo Afonso Leme Machado. Cf. Direito à informação...cit., p. 242.

${ }^{300}$ Cf. Comentários à Lei de Imprensa. 4 ed., São Paulo: Saraiva, 1989, pp. 82-83.

301 LUCAS, Javier de. Secretos de Estado. Revista del Instituto Bartolomé de las Casas. Derechos y libertades. Ano IV, Janeiro 1999, n. 7, p. 51.
} 


\subsubsection{Segredo de Estado: excepcionalidade. Casos ilustrativos referentes a investigações criminais.}

Casos ilustrativos confirmam a excepcionalidade que deve reger o segredo da informação. Em um deles - "Lame v. Department of Justice" - o Tribunal da Califórnia determinou ao governo que explicasse, de modo detalhado, os motivos pelos quais devia manter em segredo a confidencialidade e a identificação de uma fonte. ${ }^{302}$

Em outro caso - United States Department of Justice v. Landano, James V - A Suprema Corte Americana afastou a presunção de confidencialidade para todas as informações do FBI (Federal Bureau of Investigation), cabendo somente a crimes de homicídio, tráfico de drogas, evasão fiscal, terrorismo, criminalidade organizada, entre outros considerados graves. Resolveu, então que, o FBI, no curso de uma investigação criminal, deveria, em cada caso, justificar a razão da manutenção do segredo de determinadas informações solicitadas como prova, pois a publicidade, na sua maior abrangência, deve ser o propósito da Administração Pública. ${ }^{303}$

No Brasil, o “Caso TAM” gerou discussão sobre a possibilidade de o Ministério Público, para fins de investigação criminal, poder ter acesso às informações e documentos, considerados sigilosos, que estavam em poder do Centro de Investigação e Prevenção dos Acidentes Aeronáuticos - Cenipa, órgão do Ministério da Aeronáutica. ${ }^{304}$

\footnotetext{
302 “Lame v. Department of Justice”, 654 F. Supp. 2d 917 (CAD3 1981). Cf. COBO, Dolores Lavalle. Derecho de acceso...cit., p. 251, nota 70.

${ }^{303}$ Trata-se de caso no qual o acusado por roubo - Landano -, solicitou ao FBI documentos que, a seu ver, poderiam comprovar sua inocência. O órgão de informação disponibilizou aqueles que entendia possíveis de publicidade, mas reteve outros. Da decisão judicial, então, resultou que a confidencialidade implícita nos documentos não devia prevalecer e, a negativa de entrega das informações não tinha fundamento, determinando ao FBI todos os documentos solicitados. A Corte assinalou, ainda, que o FBI "durante o curso de uma investigação criminal, geralmente recolhe informações de diversas naturezas, que varia desde a extremamente sensível à de rotina, até as provenientes de fontes distintas. Isso explica a razão pela qual não corresponde à presunção de confidencialidade para todas as fontes de informação." Cf. COBO, Dolores Lavalle. Derecho de acceso...cit., p. 251, nota 71.

${ }^{304} \mathrm{Na}$ Itália vigorou uma antiga lei (25 de junho de 1909) que tutelava, de maneira rígida, o segredo ferroviário, estabelecendo que "a administração das estradas de ferro do estado não é obrigada a comunicar à autoridade judiciária a documentação e as relações dos inquéritos instaurados em todo o sinistro que tenha causado dano a pessoas ou a coisas" (art. 4 , 1). A Corte Constitucional italiana, em 1966, declarou a norma ilegítima entendendo que a possibilidade de sonegação de provas à autoridade judiciária, relevantes para o processo, fere o direito constitucional à defesa. Assim, "se se nega ou se limita à parte o poder processual de demonstrar ao juiz a realidade dos fatos que lhe é favorável, se lhe nega ou se lhe restringe o direito de exibir os meios que evidenciam aquela realidade, então há recusa ou limitação àquela tutela". Cf. GREVI, Vittorio.
} 
Para apurar eventual responsabilidade criminal no acidente aeronáutico de aeronave (FOKKER 100) da empresa TAM, ocorrido em 31 de outubro de 1996, na Cidade de São Paulo, o Ministério Público solicitou dados, informações e documentos sobre os fatos ao Ministério da Aeronáutica. A recusa das informações estribou-se em vários argumentos, dentre os quais, o de que "os documentos de investigação são reservados, sendo vedada a divulgação (Lei 8. 159/91 e Dec. 2.134/97)”.

O Superior Tribunal de Justiça, então, acolhendo pedido feito em Mandado de Segurança ${ }^{305}$, concedeu a ordem sob os seguintes fundamentos: “[...] a publicidade dos atos administrativos e demais atividades estatais decorre de preceito constitucional (Constituição Federal, art. 37). As exceções ao comando constitucional se restringem às situações em que se visa a proteger o interesse público. A Constituição só ressalva a hipótese em que o sigilo seja imprescindível à segurança da sociedade e do Estado (art. $5^{\circ}$, inciso XXXIII) [...] É certo que a Lei n. 8.191, de 1991, de que a autoridade impetrada faz escudo para a escusa na prestação de informes, prevê exceções ao princípio da publicidade. Todavia, esse princípio continua como regra, que somente cede ao interesse público relevante $[\ldots] .{ }^{, 306}$

Em relação ao caso TAM, a questão pode ser analisada, ainda, sob outro ângulo, pois as informações obtidas pelo Ministério Público, inseridas no procedimento administrativo de investigação criminal, poderiam acabar sendo divulgadas pela imprensa, uma vez que o Inquérito Policial e o Processo Penal são grandes fontes de informações dos jornalistas. É o que desenvolveremos no tópico seguinte.

\subsection{O processo penal como fonte de informação jornalística}

Aspecto de inquestionável complexidade diz respeito ao Processo Penal como fonte privilegiada e, de grande interesse, na formação das notícias pelos meios de comunicação de massa. Não são apenas as questões políticas que interessam, mas por força destas o

O segredo como limite à prova no processo penal italiano. Trad. de Roberto Orlando Pucci. In: Ciência Penal, Ano II, n. 4, São Paulo, 1975, pp. 18-19.

${ }^{305}$ Mandado de Segurança n. 5.370 DF, 12/11/1997, Relator Ministro Demócrito Reinaldo, v.u.

306 Sobre o Caso TAM, ver comentário em SÉRGIO, Mario Sobrinho. Segredo de Estado e prova ilícita. Justitia, São Paulo, 62 (189/192), jan./dez.2000, p. 140-173. 
Direito, sobretudo as que se referem às questões da Justiça Penal, tornou-se objeto preferido pela mídia, menos pela ideia de informação da opinião pública, mais pelo efeito que produz no público o "ruído encenado do espetáculo"307 da mensagem transmitida.

Nada há de errado nessa relação entre Justiça penal e mídia, desde que ela não se transforme em espetáculo circense destinado ao entretenimento, passando ao largo da função social de informar o público. O que nos propomos, no entanto, não é uma análise dos efeitos da mídia na Justiça penal, tampouco do fenômeno do espetáculo televisivo das questões criminais que, inquestionavelmente, produz uma Justiça paralela à institucionalizada, quando relata atos judiciais, interpretando-os, adaptando-os, promovendo verdadeiros julgamentos paralelos à realização do processo penal.

Portanto, não nos deteremos no estudo da divulgação das notícias dos atos judiciais e, sim, no modo e com qual objetivo são elas buscadas para serem trazidas a público.

\subsection{A investigação criminal e o segredo de justiça como limites de acesso à fonte jornalística}

A recolha de informações no âmbito do proceder da Justiça, como fonte de notícias, é uma realidade que condiz com o interesse do controle público sobre o modo de conduzir os atos procedimentais de verificação da responsabilidade dos envolvidos em crimes. E não importa, apenas, o ato que é processualmente relevante, mas tem inegável interesse público o modo de desenvolvimento, a forma de consecução de cada um dos atos procedimentais.

Isso significa admitir que, não somente a acusação formal de crime, que define o objeto do processo, e os atos subsequentes têm interesse público, mas também os elementos de prova que sustentam o convencimento do Parquet para a formalização da denúncia. Na medida em que a finalidade da fase investigativa do processo - inquérito - é

\footnotetext{
${ }^{307}$ LÚCIO, Laborinho. Processo penal e consciência coletiva. MONTE, Mário Ferreira; CALHEIROS, Maria Clara; MONTEIRO, Fernando Conde; LOUREIRO, Flávia Noversa (Coords.). Que futuro para o direito processual penal? Simpósio em Homenagem a Jorge de Figueiredo Dias, por ocasião dos 20 anos do Código de Processo Penal Português. Coimbra: Coimbra Ed., 2009, p. 136.
} 
essencialmente, "definir a acusação"308 que dará início à ação penal, a fiscalização dos seus atos deve ser permitida à sociedade.

O ponto nevrálgico da relação entre processo penal e informação midiática concentra-se na fase de investigação do crime, pois é o momento no qual surgem as fontes de notícias que mais interesse gera à imprensa e, por consequência, ao público. As peças do jogo que vão se encaixando para o desenho final do fato como ele ocorreu, instiga, sobremaneira, a curiosidade pública e também atende ao interesse comercial da empresa que vende a notícia.

Não há que se negar, no entanto, às atividades investigativas, uma importância do controle público de seu desenvolvimento, sobretudo porque as provas do fato que delas derivam poderão servir para um desfecho condenatório ou absolutório na ação penal. ${ }^{309}$

Nem mesmo o não exercício da ação penal pelo Ministério Público, com o consequente arquivamento do inquérito policial, pode justificar uma ausência absoluta de informação sobre o modo pelo qual as investigações foram conduzidas. Isso porque, os atos investigatórios, durante o inquérito, podem trazer elementos autorizadores de uma medida cautelar restritiva da liberdade da pessoa suspeita, de uma interceptação telefônica, de uma prorrogação de prisão temporária, razões de inegável interesse público no conhecimento do desenrolar administrativo da apuração dos crimes. ${ }^{310}$

Nessa etapa do jus puniendi estatal o investigado não conta com um instrumento garantidor de sua liberdade, como é o processo penal, que traz em si a obrigatoriedade de princípios constitucionais para protegê-lo da arbitrariedade da autoridade judicante. Ao contrário, submetido à investigação policial, o indivíduo não encontra barreiras de proteção suficientes para impedir que o Poder do Estado, através da polícia judiciária, ultrapasse os

\footnotetext{
308 GASPAR, António Henriques. As exigências da investigação no processo penal durante a fase de instrução. MONTE, Mário Ferreira; CALHEIROS, Maria Clara; MONTEIRO, Fernando Conde; LOUREIRO, Flávia Noversa (Coords.). Que futuro para o direito processual penal? Simpósio em Homenagem a Jorge de Figueiredo Dias, por ocasião dos 20 anos do Código de Processo Penal Português. Coimbra: Coimbra Editora, 2009, p. 89.

309 Segundo Joaquim Canuto Mendes de Almeida, a polícia judiciária prepara provas judiciais, que vão auxiliar o Poder Judiciário. Cf. Princípios fundamentais do processo penal. São Paulo: RT, 1973, p. 60.

${ }^{310}$ GIOSTRA, Glauco. Processo penale e informazione. 2 ed., Milano: Giuffré, 1989, p. 286-287.
} 
limites da estrita observância da lei ${ }^{311}$, sobretudo porque inexiste, no inquérito policial, o contraditório que possibilidade a defesa na sua maior amplitude.

Não pregamos, por isso, a total transparência do inquérito policial como instrumento de controle do Poder. A publicidade para os investigados, mídia e público, frustraria o fim do procedimento administrativo policial que é a apuração dos fatos criminais. $^{312}$ Todavia, o sigilo absoluto do inquérito, que subtrai do público informações sobre a consecução dos atos probatórios que vão embasar a ação penal e, posteriormente, submetidos ao contraditório (diferido) poderão servir para fundamentar a decisão judicial, não condiz com a importância do controle público sobre a atividade investigativa. ${ }^{313}$

A lógica midiática contemporânea vem colocando desafios à justiça penal, ainda não devidamente resolvidos. Por um lado, a investigação do crime pelo Estado deve ser livre, o investigado deve ter direitos pessoais e processuais assegurados durante o inquérito policial, o que pressupõe, num primeiro momento, a não intervenção dos meios de comunicação, porque acabam divulgando de forma espetacularizada as informações do inquérito, em afronta a princípios da presunção de inocência e dos direitos da personalidade. De outro ângulo, o Poder do Estado de buscar provas para punir aquele que infringiu a lei não pode ser realizado, na sua inteireza, à sombra da sociedade. Releva notar, ainda, que existe a possibilidade de a imprensa, a partir de uma investigação jornalística, dar origem a uma investigação criminal, ou trazer para o inquérito elementos relevantes para a apuração do crime, já iniciada.

Parece estarmos diante de interesses colidentes, sobretudo a propósito de investigações de repercussão político-midiática, as quais provocam questões de relacionamento entre o "direito ao acesso à informação e o direito dever a informar (-se) no

\footnotetext{
${ }^{311}$ MAGALHÃES GOMES FILHO, Antonio. A motivação das decisões penais. São Paulo: Ed. Revista dos Tribunais, 2001. p. 15-16.

${ }^{312}$ Para Eduardo Espínola Filho, "da própria índole das investigações policiais é que se processem com o necessário sigilo, indispensável para que as diligências não fiquem frustradas por aqueles que têm interesse em impedir seja descoberta e apurada a verdade dos fatos". Cf. Código de Processo Penal brasileiro anotado. 4. ed., Rio de Janeiro: Borsoi, 1954, v. 1, p. 313.

${ }^{313}$ Anota Jónatas E.M. Machado que "A jurisprudência norte-americana tem avançado no sentido de garantir acesso dos meios de comunicação social a todas as fases do processo, a menos que os valores em causa no caso concreto apontassem para outra solução. Assim, Press Enterprise Co. v. Superior Court of California, 464 U.S. 501 (1984); Press Enterprise Co. v. Superior Court, 478 U.S. 1 (1986)”. Cf. Liberdade...cit., nota 966, pp 563-564.
} 
confronto com os interesses específicos da integridade e proteção da atividade de investigação" 314 .

A colisão, todavia, do direito legítimo à informação e da correta investigação é aparente, sendo possível compatibilizar os interesses com normas jurídicas e deontológicas dos jornalistas. $^{315}$

Entendemos possível que o jornalista tenha acesso ao inquérito policial, como corolário do direito de se informar, para ulterior divulgação da notícia. ${ }^{316}$ A mídia pode ser útil na fiscalização da condução das investigações pelas autoridades policiais, trazendo à baila eventuais irregularidades por elas cometidas em relação ao transcurso do prazo das prisões cautelares, da violação de direitos fundamentais, na vigilância crítica das proposições de arquivamentos ou de denúncias. ${ }^{317}$

${ }^{314}$ BRAVO, Jorge dos Reis. Inquérito penal e publicidade: novas regras, os mesmos segredos. Revista do Ministério Público, Ano 30, n. 119, Lisboa: Minerva, Jul-Set 2009, pp. 13-14.

315 Para Jorge dos Reis Bravo, esta questão é que condicionou a exata origem pela opção da regra da publicidade no processo penal português, na reforma pela Lei n. 48/2007. Segundo ele, em 2006, no ponto 1 do Pacto da Justiça, no que concerne à revisão do CPP, constou restringido o segredo de justiça, passando, em regra, a valer o princípio da publicidade, só se justificando a aplicação do regime de segredo quando a publicidade prejudique a investigação ou os direitos dos sujeitos processuais ". Cf. Inquérito penal...cit., p. 14.

${ }^{316}$ Em Portugal, com a reforma do CPP, de 2007, o inquérito passou a ser público, por regra e por princípio. Conforme esclarece Manuel da Costa Andrade, "no contexto do novo ordenamento positivado, as situações de segredo de justiça ficaram reduzidas a casos decididamente marginais e excepcionais (...). A publicidade do inquérito abrange, agora, e em princípio e igual medida, tanto a dimensão interna como externa, valendo tanto na direção dos sujeitos processuais como do público em geral e, em particular, dos meios de comunicação social (...) a publicidade querida pelo legislador tende para a total transparência do inquérito na direção dos sujeitos e participantes processuais, dos media e do público, em geral. É a investigação coram populum e em interacção com as emoções, as reacções e os impulsos do povo". No plano externo, continua o autor, "o novo regime abateu todas as guardas de confidencialidade e reserva, expondo o inquérito à voracidade da curiosidade do público e sobretudo dos media, versão contemporânea do secular pelourinho. Para além de prosseguir a verdade material e a justiça, sua função patente, o inquérito acabará, também função latente, mas nem por isso menos relevante - por saciar instintos voyeuristas (...)". Cf. "Bruscamente no Verão Passado", a reforma do Código de Processo Penal. Observações críticas sobre uma Lei que podia e devia ter sido diferente. Coimbra: Coimbra Ed., 2009, p. 62-63 e 69. Ver também, sobre a questão do sigilo/publicidade no inquérito policial, após a reforma do CPP: ALBUQUERQUE, Paulo Pinto. Os princípios estruturantes do processo penal português - que futuro? MONTE, Mário Ferreira; CALHEIROS, Maria Clara; MONTEIRO, Fernando Conde; LOUREIRO, Flávia Noversa (Coords.). Que futuro para o direito processual penal? Simpósio em Homenagem a Jorge de Figueiredo Dias, por ocasião dos 20 anos do Código de Processo Penal Português. Coimbra: Coimbra Editora, 2009, pp 419-440.

${ }^{317}$ Sobre os argumentos contra o segredo de justiça, Jónatas Machado faz as seguintes considerações: "a falta de transparência e de publicidade desta fase pode favorecer a ocorrência de graves violações dos direitos dos argüidos ou da boa administração da justiça, podendo, além do mais, dar cobertura a motivações menos claras das autoridades policiais e judiciárias, ciosas de apresentar resultados rápidos do seu trabalho ou, eventualmente, receosas de atingirem determinados sujeitos particularmente poderosos e influentes ou de contenderem com interesses instalados". Cf. Liberdade...cit., p. 563. 
Porém, o procedimento administrativo de apuração de crimes, como fonte de informações deve ser limitado pelo segredo imposto pela lei, quando imprescindível para o êxito das investigações, ou seja, para a eficácia da averiguação dos fatos com a aquisição e preservação do material probatório. ${ }^{318}$ É o que determina o Código de Processo Penal brasileiro, no artigo 20: “A autoridade assegurará no inquérito o sigilo necessário à elucidação do fato ou o exigido pelo interesse da sociedade ${ }^{, 319}$, autorizando, em princípio, o acesso aos autos de inquérito policial, exceto se, para a correta averiguação dos fatos, for imposto o sigilo. Portanto, são os interesses da investigação que ditam o segredo de justiça. $^{320}$

O segredo deve limitar-se ao estritamente necessário para assegurar a eficácia do inquérito $^{321}$, principalmente quando se tratar de crimes graves praticados por pessoas públicas $^{322}$, especialmente quando no exercício das funções. E, na hipótese de suspeita de abuso de poder pelas autoridades policiais, durante o inquérito, o segredo, eventualmente imposto, deixa de ser necessário e deve ser removido. ${ }^{323}$

Extrai-se da norma do Código de Processo Penal, também, que o sigilo das investigações deve durar o tempo necessário para a realização das diligências, determinando à autoridade policial, na eventualidade de prorrogação do segredo, que o

${ }^{318}$ Sobre a derrogação do princípio da publicidade na fase do inquérito policial, Maria João Antunes diz que tal ocorre "por ser outra a forma como se procede à concordância prática das finalidades processuais conflituantes e por ser também outra a forma como se concretiza a ponderação dos direitos conflituantes que engrossam o catálogo dos direitos dos cidadãos que cabe ao processo penal salvaguardar". Cf. O segredo de justiça e o direito de defesa do arguido sujeito a medida de coacção. ANDRADE, Manuel da Costa; RODRIGUES, Anabela Miranda; COSTA, José de Faria; ANTUNES, Maria João (Coords.). Liber Discipulorum para Jorge de Figueiredo Dias. Coimbra: Coimbra Editora, 2003, p. 1245.

${ }^{319}$ No Projeto de reforma do Código de Processo Penal (156 2009) consta, no artigo 11: "Toda investigação deve assegurar o sigilo necessário à elucidação do fato e preservação da intimidade e vida privada da vítima, das testemunhas e do investigado. Parágrafo único. A autoridade diligenciará para que as pessoas referidas no caput deste artigo não sejam submetidas à exposição dos meios de comunicação".

${ }^{320}$ ANDRADE, Manuel da Costa. “Bruscamente no verão passado”... cit., p. 63.

${ }^{321}$ Segundo Carlos Frederico Coelho Nogueira, "o art. 20 do CPP prevê o sigilo do inquérito policial, não como característica sempre presente, mas como instrumento, a critério da autoridade, de assecuração da elucidação do fato ou de cautela do interesse da sociedade. A autoridade policial, a princípio, deve esclarecer, no ato instaurador do inquérito, seu caráter sigiloso. Nada impede, contudo, que o inquérito se torne cercado de sigilo apenas em determinado momento ou em determinado ato, tudo a critério de seu presidente". Cf. Comentários ao código de processo penal - e, a partir dele, aos dispositivos correlatos de toda a legislação especial inclusive o código de processo penal militar. Bauru-SP: Edipro, 2002, p. 417.

${ }^{322}$ Para Ricardo Leite Pinto, pessoas públicas, além daquelas que por alguma razão se expõem publicamente, como os músicos, também podem ser assim consideradas as que exercem uma função pública ou os titulares de cargos políticos. Cf. Liberdade de imprensa e vida privada. Revista da Ordem dos Advogados, Lisboa, ano 54, n. 27, , 1994, p. 131.

${ }^{323}$ In: Liberdade...cit, p. 564-565. 
despacho seja devidamente fundamentado, com a demonstração da necessidade exigida pelo artigo em comento.

Quanto ao primeiro requisito, de êxito das investigações, não causa maiores problemas a necessidade de se decretar o sigilo no inquérito quando a complexidade dos fatos assim determinar, e o deslinde do caso puder ser prejudicado pela indevida publicidade. Porém, quanto ao "interesse da sociedade", podendo ser entendido como "interesse público" para o sigilo das investigações, não nos parece razoável permitir que a imprecisão do termo dê margem ao arbítrio no uso do segredo, impondo limites indevidos ao acesso da mídia aos autos de inquérito.

Espínola Filho entende que o interesse da sociedade que permite a imposição do segredo para averiguação de certos crimes é aquele que pode causar danos à tranquilidade pública e repercutir negativamente diante do público. Mas esse pressuposto autorizador do sigilo, no estágio atual de desenvolvimento das comunicações globalizadas, restringe-se ao plano meramente teórico. Exatamente em virtude da projeção sem fronteiras dos atos de investigação de crimes, feita pelos meios de comunicação como imprensa televisiva, “internet", nos quais os próprios acontecimentos em tempo real - "ao vivo" - são notícias, torna-se difícil imaginar que eventual publicidade das investigações venha a causar "dano à tranquilidade pública" ou "repercutir negativamente na sociedade". Ora, se prejuízo social pode haver, é com a prática do crime e não com a divulgação da averiguação policial do fato delituoso. Nesse aspecto, portanto, o que resta é letra morta, tanto que o requisito “interesse da sociedade", autorizador do sigilo, não foi incluído no Projeto de Código de Processo Penal. ${ }^{324}$

Hoje, o segredo de justiça assume, também, uma dimensão protetiva dos direitos constitucionais, individuais e processuais da pessoa, como a tutela da privacidade, da intimidade, do bom nome, da honra e da imagem, bem como da presunção de inocência do suspeito ou indiciado. ${ }^{325} \mathrm{O}$ sigilo das investigações, justificado pelos direitos da personalidade, como limite à liberdade de informação jornalística, encontra amparo na própria Constituição da República, no art. 220, $\S 1^{\text {o }}$.

\footnotetext{
${ }^{324}$ Cf. art. 11 do Projeto CPP 156/2009, Disponível em http://www.senado.gov.br.

${ }^{325}$ COSTA, Artur Rodrigues da. Segredo de justiça e comunicação social. Revista do Ministério Público, ano 17, n. 68, p. 57, out.-dez. 1996.
} 
Embora a dimensão protetiva do sigilo seja meta ideal, é no inquérito que a imprensa, em nome da solidez da fonte, que faz mais verdadeira a notícia, encontra o meio propício para seu trabalho e se alimenta, indevidamente, mais da pessoa do indiciado ou suspeito, que acaba execrado publicamente, do que dos fatos em si, objeto justificador da informação.

Ao discorrermos sobre o sigilo das investigações como limite ao direito de informação da mídia, concluímos, então, que o inquérito policial, no Estado democrático, deve ser público, como regra, podendo encontrar respaldo na norma do art. $5^{\circ}$, LX da Constituição de 88 , embora essa se refira à publicidade dos processos. ${ }^{326}$

O sigilo, excepcionalmente, demonstrada e fundamentada a necessidade para a eficácia das averiguações, bem como para a tutela dos direitos dos investigados ou das vítimas, poderá, temporariamente, ser imposto ${ }^{327}$. É possível deduzir, então, que os meios de comunicação de massa têm um legítimo interesse ${ }^{328}$ de acesso ao inquérito policial, como fonte de informação que é, mas devem obedecer a eventual restrição de opacidade investigatória, seja ela decretada nos autos de inquérito ou por determinação legal.

\subsection{A responsabilidade do jornalista pela divulgação de informações sob segredo de justiça}

Quando a lei impõe o segredo de justiça para atos de investigação ou mesmo processuais, por consequência, o acesso a essas fontes, pelos jornalistas, fica excluído e, também, deixa de existir por parte das entidades oficiais, o dever de informar. ${ }^{329}$ É o que ocorre, por exemplo, nas hipóteses previstas no artigo $8^{\circ}$, caput da Lei 9.296/96, que

\footnotetext{
${ }^{326}$ Neste sentido, CHOUKE, Fauzi Hassan. Garantias constitucionais na investigação criminal. São Paulo: Revista dos Tribunais, 1995, p. 92.

${ }^{327}$ Nesse sentido: LEITE, André Lamas. Segredo de justiça interno, inquérito, argüido e seus direitos de defesa. Revista portuguesa de ciência criminal, ano 16, n. 4, outubro-dezembro 2006, p. 541. SILVA, Germano Marques da. A publicidade do processo penal e o segredo de justiça. Um novo paradigma? Revista Portuguesa de Ciência Criminal. Ano 18, nº 2 e 3, abril-setembro 2008, Coimbra: Coimbra Ed., p. 259.

${ }^{328} \mathrm{O}$ artigo $8^{\circ}$ do Estatuto do Jornalista, de Portugal, prevê que os jornalistas, para acederem às fontes de informações, não precisam demonstrar possuírem um interesse autônomo para informarem-se, posto que legítimo. Cf. COSTA, Artur Rodrigues da. O direito à informação, o dever de informar e os gabinetes de imprensa. In: Polícia e justiça. Revista do Instituto Superior de Polícia Judiciária e Ciências Criminais. III Série, n. 5, janeiro-Junho 2005, Coimbra: Coimbra Ed., p. 204.

${ }^{329}$ COSTA, Artur Rodrigues da. O direito à informação...cit., p. 209.
} 
determina a necessidade de preservar o sigilo das diligências, gravações e transcrições de interceptações telefônicas, bem como na quebra de sigilo financeiro para fins de apuração de crimes, conforme arts. $1^{\circ}, \S 4^{\circ}$ da LC 105/2001, em qualquer fase do inquérito ou processo judicial, devendo ser mantido o segredo de justiça externo dos autos - para os que não são partes, para o público em geral e para a imprensa. ${ }^{330}$ Por conseguinte, se houver segredo de justiça, não há possibilidade de acesso à fonte de informação e o jornalista, a ele se vincula.

No entanto, a prática tem demonstrado que, não obstante haja determinação legal do sigilo das investigações, a mídia tem meios próprios de acesso às informações, por fontes a ela ligadas. E, sustentada pelo anonimato dessas fontes, as informações sigilosas são divulgadas ao público.

Não há, no sistema jurídico brasileiro, norma que responsabilize a imprensa, criminalmente, por divulgação indevida de informações sob segredo de justiça. Cabe, portanto, ao detentor do segredo, ao funcionário que custodia a informação que deve permanecer oculta, o dever jurídico de manter o sigilo, sob pena de incidir no art. 153 ou 154 do Código Penal.

Na hipótese do artigo 10 da Lei 9.296/96, nos exatos termos ali tipificados, entendemos que o jornalista que publicar conteúdo de gravação que sabe ser sigiloso, não responde pelo crime ali descrito, pois não se vincula ao procedimento de interceptação, ao contrário do Ministério Público, juiz, autoridade policial, funcionários de cartório etc.

A violação, a quebra do segredo de justiça, foi conduta perpetrada por quem tinha o dever jurídico de preservá-lo. A posterior divulgação da informação, pela mídia, ocorre exatamente porque houve, inicialmente, a conduta delituosa de levantamento ilegal do segredo, sem que o jornalista tivesse tido acesso direto aos autos da investigação

${ }^{330}$ Sobre o sigilo na LC 105/2001, v.p.t. BELLOQUE, Juliana Garcia. Sigilo bancário: análise crítica da LC 105/2001. São Paulo: Revista dos Tribunais, 2003, especialmente p. 95. 
criminal $^{331}$. Trata-se, portanto, de crime próprio, podendo ser cometido por funcionário público, na amplitude do termo descrito no artigo 327 do Código Penal. ${ }^{332}$

Ao jornalista não se atribui um dever jurídico de preservação do segredo de Justiça e, tampouco pode ser equiparado a funcionário público. Para que a ele fosse imputado o delito de divulgação de segredo de justiça, haveria a necessidade de uma delimitação legal rigorosa da conduta vedada ao cometimento. ${ }^{333}$ Não se trata de atribuir aos profissionais da comunicação um privilégio acobertado pela liberdade de imprensa. Aqui está em pauta o princípio da legalidade que a intervenção penal exige, o qual deve encontrar no " sentido possivel das palavras', rectius, nos enunciados linguísticos vertidos nas várias incriminações, o limite para lá do qual estará no domínio da analogia proibida"334.

Todavia, a publicidade indevida do conteúdo das interceptações telefônicas, violadora dos direitos da personalidade das pessoas, não impera absoluta, à margem de eventual responsabilidade civil por danos morais. A Constituição brasileira, no artigo 220, parágrafo $1^{\circ}$, estabelece os limites da liberdade de imprensa e os direitos à honra, à intimidade, à privacidade e à própria imagem devem ser preservados, inclusive quando o

${ }^{331}$ EIRAS, Agostinho. Segredo de justiça e controlo de dados pessoais informatizados. Coimbra: Coimbra Ed., 1992, p. 62.

332 Revendo posição anteriormente firmada (VIEIRA, Ana Lúcia Menezes. Processo penal e mídia. cit., p. 224), concluímos que, nos termos do artigo $10^{\circ}$ da Lei $9296 / 96$, não é possível atribuir ao jornalista a responsabilidade penal por crime de quebra de segredo de Justiça. É o funcionário público que deve, juridicamente, manter o sigilo e, por consequência, é quem pode quebrá-lo. Aliás, no Anteprojeto de Lei sobre interceptações telefônicas, a responsabilidade penal do jornalista está prevista, quando houver divulgação por qualquer meio, inclusive pela internet, do resultado de operações técnicas legais ou ilegais. Assim preceitua o art. 24: “ No caso de crimes previstos no parágrafo $1^{\circ}$ do art. 20, no parágrafo $1^{\circ}$ do art. 21 e nos ars. 22 e 23, a pena é aumentada de um terço se a divulgação se der por meio de jornais e outras publicações periódicas, serviços de radiodifusão e serviços noticiosos, bem como pela internet. Parágrafo único. A responsabilidade penal, nesses casos, será determinada na forma dos arts. 37 a 39 da lei n. 5.250, de 9 de fevereiro de 1967”. Cf. GRECO FILHO, Vicente. Interceptação telefônica: considerações sobre a Lei n. 9.296, de 24 de julho de 1996. São Paulo: Saraiva, 2008, pp. 67-68. Sentido contrário do entendimento: SCARANCE FERNANDES, Antonio. A lei de interceptação telefônica. In: Jaques de Camargo Penteado (Coord). Justiça penal: crítica e sugestões. 1997. N. 4, p. 60. Sobre o tema ver, também: AVOLIO, Luiz Francisco Torquato. Provas ilícitas - interceptações telefônicas, ambientais e gravações clandestinas. 3. ed.,, São Paulo: Revista dos Tribunais, 2003.

333 Recentemente, jornalista brasileiro, de São José do Rio Preto, em São Paulo, foi indiciado porque divulgou informações preservadas pelo segredo de justiça. Segundo notícia, Allan de Abreu, repórter do "Diário da Região", publicou duas reportagens com dados obtidos por meio de escutas telefônicas feitas pela polícia na Operação Tamburutaca. Segundo consta, o indiciamento, nos termos da Lei 9.296/96, foi determinado pelo Ministério Público Federal após negativa do jornalista de revelar a fonte da quebra do sigilo, e porque a divulgação das informações sigilosas teria prejudicado o inquérito policial. Cf. "PF acusa repórter de publicar dado sigiloso". Folha de São Paulo, p. A 13, 30 de junho de 2011.

${ }^{334}$ PATRÍCIO, Rui; GERALDO, Tiago. O crime de violação de segredo de justiça e a reforma penal de 2007 (algumas considerações e um caso- tipo de jornalistas).Revista do Ministério Público. Ano 30, jul-set 2009, n. 119. Lisboa: Editorial Minerva, p. 53. 
segredo de justiça, em algumas hipóteses for levantado para fins exclusivos de provas no processo penal.

Não verificamos, no caso de interceptações telefônicas, uma barreira instransponível para o direito de informação da mídia. Cabe ao jornalista, quando não sigilosos os documentos, publicá-los de maneira ética, não editar as informações para o sensacionalismo, mas reproduzi-las com a maior proximidade possível da realidade dos acontecimentos fáticos.

Em virtude do grande debate que a questão tem suscitado em Portugal, vale ressaltar que a reforma legislativa de 2007, fez inserir no Código de Processo Penal desse país a proibição de publicação midiática das escutas telefônicas feitas durante as investigações judiciais. A publicação das escutas telefônicas só é possível se não estiverem sob segredo de justiça e, concomitantemente, houver a anuência dos intervenientes processuais. ${ }^{335}$ A violação do preceito normativo poderá levar o jornalista a ser punido com pena de prisão ou multa.

A normatização naquele país ocorreu, originada de uma especial indefinição doutrinária e jurisprudencial, quanto à possibilidade, ou não, de o jornalista ser autor do crime de violação de segredo de justiça. O problema, à época, cingia-se à autoria do crime, ou seja, se somente os participantes processuais e aqueles que tinham o dever jurídico de sigilo poderiam responder pelo delito, ou também qualquer pessoa que tivesse tido acesso direto ou indireto aos autos do processo. ${ }^{336}$

Segundo Paulo Albuquerque, o que motivou o legislador a regulamentar a publicação do teor das escutas telefônicas, pelos meios de comunicação de massa foi "render homenagem ao direito à palavra e impedir a devassa, 337, porém a incriminação do

335 ARAÚJO, Cláudia. Os crimes dos jornalistas. Uma análise dos processos judiciais contra a imprensa portuguesa. Coimbra: Almedina, 2010, p. 120. Conforme dispõe o CPPP, no art. 88, 4: "não é permitida, sob pena de desobediência simples, a publicação, por qualquer meio, de conversações ou comunicações interceptadas no âmbito de um processo, salvo se não estiverem sujeitas a segredo de justiça e os intervenientes expressamente consentirem na publicação".

${ }^{336}$ ARAÚJO, Cláudia. Os crimes...cit., p. 108.

${ }^{337}$ No caso "Casa Pia", 57 (cinquenta e sete) jornalistas foram acusados de prática de violação de segredo de justiça, pois divulgaram o teor de escutas telefônicas na investigação de notícias de abusos sexuais nos colégios da Casa Pia em Lisboa. Ao final do processo, 16 jornalistas foram julgados e absolvidos, porque 
jornalista pela violação da proibição é inconstitucional, porque excessiva e desproporcional. ${ }^{338} \mathrm{E}$ acrescenta ele que o art. 88, n. 4, "constitui uma incriminação que pune o mero exercício de uma profissão e, assim, restringe de forma inadmissível a liberdade de expressão dos jornalistas, pondo em causa o princípio da mínima intervenção do direito penal". 339

\subsection{O investigador midiático e o processo penal: procedimento de busca das informações jornalísticas. Fontes ocultas. "Câmeras escondidas". Interceptações telefônicas.}

O segredo de justiça, que impõe barreira limitativa na liberdade de imprensa, não impede que os meios de comunicação investiguem fatos referentes à prática de delitos, de maneira independente e sem que se restrinjam às fontes públicas e oficiais de informações.

Na busca da informação e diante da necessidade de comprovar a verdade do acontecido, o jornalista começa, por meios próprios, a desbravar territórios desconhecidos, procurando as próprias fontes de notícias. O profissional, então, procura estabelecer a verdade dos fatos pela provas destes, buscadas e divulgadas de modo próprio, da maneira indicada pela intuição e pelo "espírito investigativo".

O caminho da investigação justifica-se, sob a ótica do profissional, porque não pretende ser um "porta-voz do Poder"340 instituído, que disponibiliza a informação dentro de critérios de conveniência. Não só, mas a pluralidade de "versões" sobre o fato faz surgir uma notícia mais "verdadeira", e o repórter cumpre melhor, o compromisso social de bem informar. $^{341}$

\footnotetext{
"não sendo intervenientes processuais, não acedendo às fontes de modo fraudulento, não cometeriam o crime de violação de segredo de justiça". Cf. ARAÚJO, Cláudia. Os crimes...cit., p. 124.

${ }^{338}$ ALBUQUerQue, Paulo Pinto de. Comentário do Código de Processo Penal à luz da Constituição da República e da Convenção Europeia dos Direitos do Homem. $3^{\text {a }}$ ed. actualizada. Lisboa: Universidade Católica Editora, 2009, p. 246, nota 8.

${ }^{339}$ ALBUQUERQUE, Paulo Pinto de. Comentário...cit., p. 247, nota 09.

${ }^{340}$ MORÃO, Helena. Responsabilidade jurídico-penal dos jornalistas por violação do segredo de Estado: contributo para o estudo do tema segurança e comunicação social. In: GOUVEIA, Jorge Bacelar; PEREIRA, Rui. (Coords.). Estudos de direito e segurança. Lisboa: Almedina, 2007, p. 159.

${ }^{341}$ TEIXEIRA, Mônica. Investigação é fundamento do jornalismo. In: LOPES, Dirceu Fernandes; PROENÇA, José Luiz. (Orgs.). Jornalismo investigativo. São Paulo: Publisher Brasil, 2003, p. 176.
} 
O jornalista, então, "sai a campo" para fazer descobertas de fatos ou de crimes, a partir das informações que recebeu. O caminho é traçado enquanto se caminha. Aqui reside o maior problema de uma atividade com relevante fim social. O meio para se investigar possui técnicas e estratégias próprias para serem desenvolvidas ao longo do processo investigativo. A redação do jornal se converte em delegacia de investigação, o repórter em policial, o redator converte-se em promotor e o editor, em juiz. ${ }^{342}$ Não há, no jornalismo, procedimento formal de apuração dos fatos que serão notícias, como ocorre na investigação ou processo penal, cujos métodos utilizados na busca das provas só podem ser aqueles prescritos em lei.

Inicia-se a investigação, tradicionalmente, com base em boatos, ou notícias de fontes anônimas ou mesmo, informações confidenciais. Passa-se, então, à "checagem" da informação por meio de busca de provas, de evidências que corroborem a notícia que, à primeira vista, parece ter relevância pública.

O anonimato da fonte, porém, se por um lado assegura ao repórter que ele terá a informação, por outro, pode propiciar acusações infundadas, caluniosas, abusivas e portadoras de motivações de toda ordem de interesses. ${ }^{343}$ Por vezes, a fonte pode não ter condições de saber o grau de certeza do que diz, mas o faz com boa-fé, sob o compromisso de o jornalista mantê-la no anonimato, sem o qual não revelaria o fato que pode levar, por hipótese, à descoberta de um escândalo de corrupção.

De qualquer maneira, a importância das fontes para o jornalismo investigativo é inquestionável. Essa, aliás, é a realidade da imprensa em todo o mundo, e no Brasil não é diferente. São inúmeros os casos de crimes envolvendo pessoas públicas, cujas

\footnotetext{
${ }^{342}$ Sobre o jornalismo investigativo, sobretudo nas questões policiais e do Judiciário, Frederico Vasconcelos, com propriedade, afirma: "Percebo que a indignação da sociedade com a sequência de escândalos no Executivo, no Legislativo e no Judiciário dificulta uma análise serena sobre a atuação da mídia e os limites de seu ofício. A frustração e a perplexidade diante da impunidade geram a expectativa de que a imprensa cumpra um papel que não é seu. São preocupantes as pesquisas revelando que considerável parcela da população acredita que a imprensa é a instituição que mais contribui para a realização da justiça. Trata-se de uma distorção. Costumo dizer que repórter não é policial, redator não é promotor e editor não é juiz". Cf. Anatomia da reportagem: como investigar empresas, governos e tribunais. São Paulo: Publifolha, 2008, p. 141.

${ }^{343}$ As fontes anônimas têm sido preocupação entre os norte-americanos, cujos jornais estão fixando regras garantidoras da independência de seus veículos informativos. Esclarece Cleofe Monteiro de Sequeira, que desde Watergate, o jornal The Washington Post exige que os dados obtidos pelos seus profissionais sejam confrontados com três fontes especializadas e independentes acerca da questão, antes da publicação da notícia. Cf. Jornalismo investigativo...cit., p. 87.
} 
investigações pela mídia desenvolvem-se paralela e concomitantemente aos inquéritos policiais, apoiada na pretensa solidez das fontes que sustentam a credibilidade do fato delituoso averiguado pela imprensa.

Problema de crescente intensidade, no entanto, é que as investigações deflagradas através de fontes sigilosas, contam também com provas que corroboram as notícias, recolhidas por meios nem sempre legais. As câmeras ocultas, o "repórter infiltrado", as interceptações telefônicas são práticas de um jornalismo investigativo que vem se desenrolando à margem dos direitos constitucionais da pessoa humana, como a intimidade, a honra, a privacidade e a imagem.

Um dos meios de se conseguir a "comprovação" do crime, atualmente, é o uso de câmeras ocultas na produção de reportagens, ou seja, procede-se a filmagem de fatos com microcâmeras, sem o consentimento das pessoas protagonistas. ${ }^{344}$ Ainda que a publicação dessas informações revista-se de proteção constitucional, porque pode haver um interesse público na notícia, é discutível a postura ética do jornalista que se utiliza desses métodos para realizar seu trabalho.

No âmbito restrito da imprensa investigativa, o assunto não encontra consenso entre os doutrinadores. Há aqueles que admitem o uso de câmeras ocultas, como meio de busca de provas para fundamentar a reportagem, quando utilizados em ambientes públicos, reprovando, no entanto, a utilização em locais privados. ${ }^{345}$ Outros, admitem o uso, não obstante entendam que o recurso a essa técnica faz apenas um "pseudo-jornalismo, um infoshow" ${ }^{346}$. Chega-se, até mesmo, a revestir o uso do meio tecnológico com uma "presunção de legitimidade", quando se trata de descobrir fraudes ou casos de corrupção, investigação sobre temas de interesse público, justificando, inclusive, a violação dos direitos constitucionais personalíssimos das pessoas envolvidas. ${ }^{347}$

\footnotetext{
${ }^{344}$ BADENI, Gregorio. Tratado de libertad de prensa. Buenos Aires: Abeledo Perrot, 2002, p. 789.

345 BARCELLOS, Caco. Jornalismo ativo. In: LOPES, Dirceu Fernandes; PROENÇA, José Luiz. (Orgs.). Jornalismo investigativo. São Paulo: Publisher Brasil, 2003, p. 164.

${ }^{346}$ SÁEZ, Maria Tereza Mercado. El infoshow com cámara oculta: investigación periodística o espetáculo? Sala de Prensa. Web para professionales de la comunicacion iberoamericanos, n. 84, ano VII, vol. 3, octubre 2005. Disponível em http://www.saladeprensa.org/art640.htm, acessado em 18.08.2011, p. 2.

347 GARIBALDI, Gustavo E. L. Las modernas tecnologias de control y de investigación del delito: su incidência em el derecho penal y los princípios constitucionales. Buenos Aires: Ad-Hoc, 2010, p. 300.
} 
O Tribunal Federal da Argentina já aceitou esse modo de investigação jornalística, decidindo que "os simples particulares não se encontram compreendidos pelos limites formais estabelecidos pela lei processual penal e não parece ser razoável, como se pretende neste caso, exigir da imprensa a obtenção de uma ordem judicial para realizar uma investigação, tampouco que o repórter apresente ao interlocutor, seus direitos, antes de conversar com ele". 348

Em outra oportunidade ${ }^{349}$ o Tribunal entendeu que não obstante o tema abordado na matéria jornalística fosse de interesse público, não era válido destruir os direitos personalíssimos dos indivíduos, através de meios enganosos, para alcançar o objetivo de divulgação. ${ }^{350}$

Também a "matéria-prima"351 do jornalismo investigativo, de generalizada prática, é o uso das interceptações telefônicas pelos repórteres ${ }^{352}$, ou a eles entregues por fontes cujo anonimato é prometido. $\mathrm{O}$ direito a investigar condutas supostamente delituosas não pode admitir a utilização de meio ilegal de obtenção de informações. A interceptação das comunicações telefônicas é um "meio oculto de investigação criminal”353, admissível, tão

${ }^{348}$ BADENI, Gregorio. Tratado de libertad ...cit., p. 794.

349 Nos EUA, repórteres disfarçados e câmeras ocultas fram alvo de processo contra uma rede de TV americana, em 1992, pois fizeram reportagem sobre os bastidores de um supermercado da Carolina do Norte. Os repórteres empregaram-se na loja, gravaram conversas de decisões dos funcionários do supermercado que alteravam a data de validade dos produtos, como carne e enlatados. Os funcionários do supermercado alegaram que o prejuízo da reportagem veiculada em novembro de 1992, foi muito grande. O júri condenou os repórteres à multa correspondente ao dobro do valor do prejuízo do estabelecimento comercial, além de condenação por falsidade ideológica, por gravarem conversas e imagens com câmeras escondidas de pessoas desavisadas. Cf. Disponível em http://www.slideshare.net/lorenavalois/limites-legais-para-o-jornalismoinvestigativo. Acesso em 27 set. 2011.

${ }^{350}$ Caso "M.J.A. c Canal 13 de Televisión (Arte Radiotelevisivo Arg. S.A.) s da os y perjuicios". CNCrim, y Correc., Sala L, 02/10/2008, expte.66.653 (54.353/02). Cf. GARIBALDI, Gustavo E. L.. Las modernas tecnologias... cit., p. 305.

351 DELMANTO, Renato. O direito à preservação da fonte: a mídia e o grampo. Disponível em http://bdjur.stj.gov.br. Acesso em 21 fev. 2010.

${ }^{352}$ De repercussão internacional foi o caso do jornal britânico "Ne s of the ord", que desde 2002 fazia escutas telefônicas ilegais em busca de informações para suas reportagens. Em 2007, o correspondente do jornal para assuntos da realeza, Clive Goodman e o investigador Glenn Mulcaire, foram condenados à prisão porque realizaram grampos ilegais nos telefones de membros da família real. Em 2011, nova investigação policial iniciou-se, diante de denúncias de que inúmeras pessoas entre políticos, artistas e celebridades, tiveram seus telefones interceptados pelo referido Jornal. Os responsáveis pelo jornal acabaram admitindo o uso desse meio para a busca de informações.

353 ANDRADE, Manuel da Costa. Métodos ocultos de investigação. (plädoyer para uma teoria geral). ? MONTE, Mário Ferreira; CALHEIROS, Maria Clara; MONTEIRO, Fernando Conde; LOUREIRO, Flávia Noversa (Coords.). Que futuro para o direito processual penal? Simpósio em Homenagem a Jorge de Figueiredo Dias, por ocasião dos 20 anos do Código de Processo Penal Português. Coimbra: Coimbra Editora, 2009, p. 540. 
somente, nos estritos termos da lei. Quando utilizado por jornalistas, não importando se o fim da medida é público, inadmissível que ele invoque a "autorização" constitucional decorrente da liberdade de imprensa, pois o repórter não pode fazer o papel do policial, muito menos ir além.

Nos dias atuais, o "processo investigativo" da mídia que, como rotina se utiliza dos conhecidos "grampos", assemelha-se ao método utilizado nos procedimentos inquisitoriais, no qual o réu, e não o crime, tornava-se objeto de investigação e como pecador era "detentor de uma verdade a ser extraída" $" 354$. Hoje, as confissões são extorquidas das pessoas que se supõem responsáveis, por meio de gravações ou grampeamentos telefônicos e a publicação posterior do teor das conversas, instantaneamente, legitima, socialmente, a verdade dos fatos. Inicia-se, então, o tormento, a flagelação daquela pessoa que é exposta publicamente pelos meios de comunicação, até que ocorre seu "julgamento" pela opinião pública. ${ }^{355}$ Essa "voracidade" da divulgação pública, feita pelos meios de comunicação, é, para Manuel da Costa Andrade, "a versão contemporânea do secular pelourinho"356.

Difícil é compreender que as modernas tecnologias de comunicação nos levem de volta a um período em que a violação de direitos era a regra e o processo se desenvolvia sob o manto do absoluto segredo, que justificava os meios mais cruéis de obtenção de provas, os quais acabavam legitimados.

Outra situação que se estampa é a publicação das informações recolhidas por meios ilícitos, mas por pessoas estranhas aos jornalistas. Nessa hipótese, como os profissionais da imprensa contam com a possibilidade de manterem as fontes no anonimato, a divulgação dessas notícias, sem a participação do jornalista ou da empresa à qual ele está vinculado, prima facie, merece a tutela constitucional. ${ }^{357}$

\footnotetext{
${ }^{354}$ COUTINHO, Jacinto Nelson de Miranda. Sistema acusatório: cada parte no lugar constitucionalmente demarcado. In: __ CARVALHO, Luis Gustavo Grandinetti Castanho de. (Orgs.). O novo processo penal à luz da Constituição (Análise crítica do Projeto de Lei n. 156/2009, do Senado Federal). Rio de Janeiro: Lumen Juris, 2010. p. 4.

${ }^{355}$ Frederico Vasconcelos diz perceber que "a indignação da sociedade com a sequência de escândalos no Executivo, no Legislativo e no Judiciário dificulta uma análise serena sobre a atuação da mídia e os limites de seu ofício. A frustração e a perplexidade diante da impunidade geram a expectativa de que a imprensa cumpra um papel que não é seu". Cf. Anatomia da reportagem...cit.,p. 141.

356 Cf. "Bruscamente no verão passado", a reforma do código de processo penal: Observações críticas sobre uma lei que podia e devia ter sido diferente. Coimbra: Coimbra Editora, 2009, p. 69.

${ }^{357}$ MACHADO, Jónatas E. M. Liberdade.... cit., p. 578.
} 
Em algumas situações, é legítima a publicação de notícias colhidas por terceiros e entregues os materiais aos jornalistas, ainda que produzidos por meios ilegais, pois decorre do livre direito de informação da mídia. Nessa linha de raciocínio, a concessão de liminares pelo Poder Judiciário, para impedir a divulgação de notícias que afetem a honra ou imagem de pessoas públicas, cuja notoriedade restringe a área de abrangência de sua intimidade, é indevida e caracteriza, a nosso ver, censura prévia ${ }^{358}$, medida intolerável em um Estado democrático ${ }^{359}$. A censura inadmissível, no entanto, é aquela que se pretende coibir a imprensa de divulgar informações de interesse público, ainda que invada o direito personalíssimo de uma pessoa com notoriedade. ${ }^{360} \mathrm{O}$ que não significa estar o Judiciário impedido de agir, preventivamente, em casos inequívocos de abusos da imprensa que pretende publicizar fatos que não estejam revestidos de interesse público e afetem a vida privada, a honra e imagem de particulares, ou mesmo quando se trate de "segredos de alcova" de pessoas públicas. ${ }^{361}$

De qualquer maneira, há uma atitude legítima da imprensa de fazer conhecer informações trazidas por terceiros, ainda que tenham sido colhidas à margem da lei, cuja

\footnotetext{
${ }^{358}$ María Angélica Gelli, afirma que o alcance e a proibição da censura prévia em contraposição à liberdade de expressão, são questões controvertidas, das quais decorrem as perguntas: "Que ações implicam a censura prévia? A quem está dirigida a proibição? A todos os poderes do Estado, incluindo o Judiciário? Qual é o alcance do termo ideias? Elimina-se a garantia da publicação de informações ou notícias, de imagens ou de sons?". Conclui pela possibilidade de restrições, asseguradas essas nos Tratados Internacionais de Direitos Humanos, para um devido equilíbrio entre direitos e deveres relativos à liberdade de expressão. Cf. Libertad de expresion em Argentina: los desafios de la nueva comunicacion. In: SANDLER, Hector R. (Coord.). El cuarto poder: expresion, informacion y comunicacion social. Buenos Aires: Ediar, 1999, p. 215.

${ }^{359}$ Nesse sentido: CARVALHO, Luis Gustavo Grandinetti Castanho de. Processo Penal...cit., p. 261. É o entendimento, também, de José Saez Capel, para quem o exercício da liberdade de expressão, embora não possa ser censurado, não isenta aquele que o utiliza das responsabilidades civis e penais: “ precisamente nesta instância ex post quando pode levar-se a cabo a reparação dos eventuais danos produzidos ao lesionar direitos de terceiros". Cf. El derecho a la intimidad y las escuchas telefônicas. Buenos Aires: DIN, 1999, p. 129.

360 Anota Luis Gustavo Grandinetti Castanho de Carvalho que "A teoria dos três círculos concêntricos permite graduar a esfera de intensidade da proteção à intimidade. É, justamente, no espaço destinado a essa graduação que o direito à intimidade tem que ceder diante de um outro direito constitucional. Isso equivale a dizer que alguns titulares desse direito têm proteção menos intensa do ordenamento jurídico e outras o têm mais intensa; uns só merecem proteção na esfera mais restrita, enquanto outros têm proteção integral. Em outras palavras, as pessoas públicas que exercem cargo de direção e de gestão da coisa pública podem merecer menor grau de proteção diante do interesse público superior da sociedade em informar-se a respeito de seus mandatários". Cf. Processo penal e Constituição...cit., p. 257.

361 Conforme lição de Gilmar Ferreira Mendes: "Diante dos termos peremptórios em que se encontra formulado o art. $5^{\circ}, \mathrm{X}$, da Constituição - são invioláveis a intimidade, a vida privada, a honra e a imagem das pessoas [...] -, parece evidente que o constituinte não pretendeu assegurar apenas eventual direito de reparação ao eventual atingido. A referência que consta da parte final do dispositivo - assegurado o direito a indenização pelo dano material ou moral decorrente de sua violação - somente pode dizer respeito aos casos em que não foi possível obstar a divulgação ou a publicação da matéria lesiva aos direitos da personalidade". Cf. Direitos fundamentais e controle de constitucionalidade: estudos de direito constitucional. 2 ed. rev. atual. São Paulo: Celso Bastos Editor: Instituto Brasileiro de Direito Constitucional, 1999, p. 90.
} 
valoração da conveniência da divulgação da notícia tão somente a ela é atribuída, não excluindo, no entanto, sua posterior responsabilidade civil e penal, pelas consequências lesivas aos direitos personalíssimos das pessoas. Não poderíamos defender postura diversa, sob pena de admitirmos a existência de um direito absoluto da mídia de agir, contrariando as barreiras legais da liberdade de informação, previstas no artigo 220 da Constituição da República.

No julgamento do Caso O Globo vs. Garotinho, ${ }^{362}$ no qual o Supremo Tribunal Federal indeferiu o pedido da empresa Infoglobo e outros de autorização liminar de publicação do conteúdo de gravação obtida ilicitamente, o Ministro Marco Aurélio de Mello, em voto divergente, posicionou-se contrariamente à censura prévia da imprensa, pelo Judiciário, admitindo que as informações sobre homem público, candidato à Presidente da República, possuem relevante interesse coletivo o qual, aliás, sobrepõe-se aos direitos personalíssimos do cidadão e à eventual ilicitude de fitas gravadas à margem da disciplina própria, numa interceptação de ligação telefônica, não obstante a necessidade de apurar a responsabilidade pela gravação.

No caso em tela, o acórdão recorrido do Tribunal de Justiça do Rio de Janeiro contou com voto vencido do Desembargador Samuel Marques, no qual enfatizou a importância da veiculação de gravações, ainda que obtidas de forma considerada ilícita, pois se trata de fatos envolvendo pessoa que exerce função pública. E acrescentou que, in casu, não estava em discussão a possibilidade de "fazer prova mediante a utilização das gravações telefônicas. Não se está diante de um processo cível ou penal, no qual as

\footnotetext{
${ }^{362}$ STF, Tribunal Pleno, Medida Cautelar em Petição 2.702-7, Rio de Janeiro, Ministro Relator Sepúlveda Pertence, DJ 19.09.2003. Relatório: “Anthony illiam Garotinho Matheus de Oliveira - então Governador do Estado do Rio de Janeiro - requereu medida cautelar contra Infoglobo Comunicações Ltda. - que edita no Rio os diários O Globo e Extra Informações -, outras empresas de comunicação social e dois repórteres do primeiro dos jornais mencionados. 2. Refere a petição que edição de $\mathrm{O}$ Globo da mesma data de seu ajuizamento veicula reportagem assinada pelos repórteres aludidos, sob o título Garotinho sabia de suborno, no qual se noticiara que conversas gravadas de 1995 mostram que o governador Anthony Garotinho (PSB) participou de operação de suborno do auditor fiscal da receita federal M.P.A, responsável pela aprovação dos sorteios feitos pelo programa Sho do Garotinho, que foi ao ar naquele ano pela Rádio Tupi e pela TV Bandeirantes . 3. A mesma matéria informava ser a gravação - fruto da interceptação de conversas telefônicas entre Garotinho e dois interlocutores diversos - atribuída a terceiro apenas identificado como um dos responsáveis pelas denúncias .
} 
gravações podem ou não servir como prova. Elas podem, isso sim, ser usadas em prol da informação do público leitor"363.

Ainda que não estejamos diante de uma formal investigação ou processo criminal, o trabalho da imprensa investigativa não prescinde da submissão à ética ${ }^{364} \mathrm{e}$ à lei, sobretudo aos princípios que circundam a proteção da dignidade humana. Assiste razão a Gustavo Garibaldi $^{365}$, quando defende uma exigência de formação técnica do profissional especializado para desenvolver essa modalidade de jornalismo, com o conhecimento de normas legais que conduzam e limitem sua atividade de busca de informações.

\subsection{Os meios de busca da verdade midiática e o inquérito policial}

$\mathrm{O}$ aspecto que nos toca mais de perto, no entanto, é o reflexo que o material recolhido através da prática ilegal de obtenção da notícia, publicado pelos meios de comunicação, poderá ter em relação às investigações criminais. Nas hipóteses de interceptações telefônicas ou de outros meios que ofendam os direitos personalíssimos dos indivíduos, ainda que a Constituição as agasalhe sob o manto da liberdade de imprensa quando divulgados seus conteúdos, poderão assumir contornos de ilicitude e, neste caso, não devem ser admitidas como "noticia criminis" de instauração de inquérito policial ou como prova nas investigações ${ }^{366}$.

Diante do progresso tecnológico, os pontos de partida para as investigações criminais alteraram-se substancialmente, e os métodos secretos de averiguação dos crimes

\footnotetext{
363 Voto vencido contido no acórdão do Tribunal de Justiça do Rio de Janeiro, citado no acórdão STF, Tribunal Pleno, Medida Cautelar em Petição 2.702-7, Rio de Janeiro, Ministro Relator Sepúlveda Pertence, DJ 19.09.2003.

${ }^{364}$ Enfatiza nio Santarelli Zuliani que "o valor ético do jornalista não é igual ao do juiz; o profissional da mídia valoriza o interesse público sem preocupação com o interesse individual e, normalmente, atua certo de que a figura pública não possui reserva fora de seu lar (...)”. Cf. GOMES JR, Luiz Manoel. (Coord.) Comentários à lei de Imprensa: Lei 5.250/1967-artigo por artigo. São Paulo: Revista dos Tribunais, 2007, p. 173.

${ }^{365}$ Cf. Las modernas tecnologias...cit., p. 321.

366 Sobre o uso de câmeras ocultas, Gerardo Prat diz que a ética deve julgar a validade do recurso tecnológico, quando não existem limites claros acerca de sua utilização. Assim, "quando falamos de violar ou não a vida privada, temos um limite claro: a lei. Porém, quando a lei não é clara e precisa quanto à publicação daquilo que foi obtido com uma câmera oculta, não quer dizer que tudo está permitido. Então, entramos no campo da ética". Cf. Límites éticos y legales de La investigación com cámara oculta. Disponível em www.saladeprensa.org. Acesso em 20 de maio 2011.
} 
acabam convergindo com esses meios de busca da verdade midiática, encontrando-se "num espaço de intervenção alargado e muito para além da suspeita de crime"367. São visíveis as alterações que se desenham no campo das investigações criminais e da produção probatória no processo penal, quanto mais avançam os meios tecnológicos de informação. A imprensa, como um dos campos da sociedade civil, conta com informações e conhecimentos de grande interesse para as autoridades de investigação criminal, as quais não devem ser desprezadas.

É preciso, então, colocar em pauta a discussão sobre formas conciliatórias de um processo penal efetivo ${ }^{368}$ com resposta à criminalidade crescente, da minimização das restrições dos direitos fundamentais dos investigados ou acusados e da participação da sociedade na prevenção e repressão aos crimes, inclusive através dos meios de comunicação.

Primeiramente, avulta a necessidade de frisarmos que estamos diante de busca de verdades distintas, as quais, não necessariamente, deverão convergir para um único ponto. A "verdade" que vai fundamentar uma eventual denúncia ou sentença penal condenatória vai trilhar caminhos e visar a finalidades diversas da "verdade" buscada pela imprensa, que pretende, pela divulgação da notícia, servir ao interesse público. Segundo Manuel da Costa Andrade, "um qualquer enunciado que não logre atingir as credenciais da verdade exigida para a condenação penal pode, apesar disso, valer como a mais consistentes das verdades jornalísticas. [...] em rigor, se trata de juízos diferentes a dizer coisa diferente de coisas

\footnotetext{
${ }^{367}$ ALBRECHT. Hans-Jörg. Vigilância das telecomunicações. Análise teórica e empírica da sua implementação e efeitos. Trad. de Inês Fernandes Godinho. In: MONTE, Mário Ferreira; CALHEIROS, Maria Clara; MONTEIRO, Fernando Conde; LOUREIRO, Flávia Noversa (Coords.). Que futuro para o direito processual penal? Simpósio em Homenagem a Jorge de Figueiredo Dias, por ocasião dos 20 anos do Código de Processo Penal Português. Coimbra: Coimbra Ed., 2009, p. 726.

${ }^{368}$ Utilizamos aqui o termo "efetivo", no sentido de "fim, objetividade, realizado para o fim proposto", seguindo a distinção que Jacinto Nelson de Miranda Coutinho faz entre efetividade e eficiência. Para o doutrinador, a eficiência diz respeito aos meios, enquanto a efetividade analisa os fins. Cf. Efetividade do processo penal e golpe de cena: um problema às reformas processuais. In: WUNDERLICH, Alexandre. Escritos de direito e processo penal em homenagem ao professor Paulo Cláudio Tovo. Rio de Janeiro: Lumen Juris, 2002. P. 143 e ss. Sobre o tema da eficiência e efetividade do (e no) processo penal, ver: SCARANCE FERNANDES, Antonio. Reflexões sobre as noções de eficiência e de garantismo no processo penal. In: SCARANCE FERNANDES, Antonio; ALMEIDA, José Raul Gavião de; MORAES, Maurício Zanoide de. Sigilo no processo penal: eficiência e garantismo. São Paulo: Revista dos Tribunais, 2008, p. 9-28.
} 
diferentes". 369 No entanto, "verdades" trazidas pela imprensa poderão deflagrar investigações criminais e darem início à busca da "verdade" no processo penal.

A reportagem elaborada com o uso de filmagens, infiltração do jornalista entre criminosos, por meio de escutas ou interceptação de conversa telefônica, pode trazer a lume a ocorrência de fatos delituosos, e acabam dando ensejo à instauração de inquérito policial, ou elementos de prova para a investigação criminal. Na maior parte das vezes, as notícias assim produzidas buscam fatos envolvendo figuras públicas, políticos, ou crimes que atingem um grande número de pessoas, ou uma comunidade. ${ }^{370}$

A questão das interceptações telefônicas como típico meio de busca da prova na fase das investigações criminais, é assunto polêmico e de difícil consenso, quando se discute a possibilidade, ou não, de o material publicado pela mídia, ou seja, a divulgação das conversas telefônicas, poder servir como indícios para instauração de investigações de delitos ou, até mesmo, de elemento de prova em inquérito policial.

Antes, porém, necessário distinguir a interceptação telefônica da gravação clandestina e gravação ambiental. A doutrina entende que a captação de conversa de interlocutores, sem o conhecimento deles ou com o conhecimento de só um deles, feita por terceiros, é o que define a interceptação telefônica. ${ }^{371} \mathrm{E}$ o que a caracteriza como tal, é a

369 ANDRADE, Manuel da Costa. Liberdade de imprensa e inviolabilidade pessoal: uma perspectiva jurídico-criminal. Coimbra: Coimbra Ed., 1996, p. 213.

${ }^{370}$ Emblemático o caso do jornalista Tim Lopes que, munido de uma mini câmara oculta, infiltrou-se entre traficantes em um morro de favela do Rio de Janeiro, pretendendo investigar "Feiras de Drogas" instaladas no caminho que crianças percorriam para irem à escola. Em oportunidade anterior, o mesmo repórter investigativo, intitulando-se paciente, internou-se em diversas clínicas de recuperação para drogados no intuito de comprovar quão precário era o atendimento dispensado aos pacientes, além da existência de maustratos às pessoas internadas. Cf. FORTES, Leandro. Jornalismo...cit., fls. 73-74. Não podemos deixar de mencionar que o jornalista foi barbaramente assassinado pelos traficantes que ele investigava, o que levou a imprensa a começar a questionar esse modo policialesco de se fazer jornalismo.

${ }^{371} \mathrm{O}$ autor português, Benjamim Silva Rodrigues, faz análise da polissemia da expressão "escutas telefônicas". Ao escrever sobre a noção de "interceptação", primeiramente anota o sentido da palavra como "interceptar", "interromper o curso". Assim, segundo ele "isto levar-nos-ia a concluir que a interceptação consiste na interrupção do curso de uma conversação ou comunicação telefónica, mas não é o que verdadeiramente acontece com o ato de interceptação e gravação do curso (normal) de uma conversa telefónica e, nem tampouco "a limitação do direito ao segredo nas comunicações telefónicas não pode consistir em impedir a comunicação, isto é, em que o suspeito não possa fazer ou receber chamadas de telefone. Porque, tal situação é uma restrição ilegítima de um direito fundamental, não acolhido constitucionalmente. Conclui, citando doutrinadores e jurisprudências estrangeiras, que a interceptação deve ser entendida como atividade de um terceiro que, por meios mecânicos, capta, toma conhecimento da comunicação alheia reservada, sem que pelo menos, um dos interlocutores tenha conhecimento. Finalmente, diz o autor, "o que não se pode esquecer é que o primeiro elemento indefectível das interceptações 
"terzietă" referida pela doutrina italiana. ${ }^{372} \mathrm{~A}$ interceptação telefônica, ainda, pressupõe que o meio utilizado para captar a conversa seja o "grampeamento" do telefone. Se a conversa for captada por um gravador, colocado por terceiro, trata-se de interceptação ambiental ou escuta. ${ }^{373}$ Há, também, a gravação clandestina de conversa telefônica (ou não) própria, com o outro, mas sem o conhecimento deste.

A Constituição Federal cuidou da interceptação telefônica (art. 5 , XII), não abrangendo a gravação de conversa por terceiros ou um dos interlocutores. Mas a essa se aplica o limite legal da proteção à intimidade, previsto no art. $5^{\circ}, \mathrm{X}$ da Carta Magna. ${ }^{374} \mathrm{O}$ tratamento dado à gravação clandestina, portanto, não é o mesmo regulamentado na Lei 9.296/1996, para as interceptações telefônicas. Poderá, no entanto, a divulgação do conteúdo da gravação, se não houver justa causa, ser considerada crime de violação de segredo, nos termos do art. 153 do Código Penal.

Partindo dessas presmissas poderemos fazer algumas reflexões que nos guiarão no caminho das análises seguintes.

Se o jornalista publica matéria cujas informações foram colhidas por meio de interceptações telefônicas ilegais, porque realizadas por ele, qualquer prova trazida pela Polícia Judiciária, a partir daquelas notícias, estará contaminada pela ilicitude, segundo a teoria dos "frutos da árvore envenenada". Se a notícia do crime divulgada pela mídia foi adquirida ilicitamente, as provas que decorrem da investigação policial, a partir daquela informação midiática, também o serão. Não se pode justificar a prática de um delito para a

correlaciona-se estreitamente com o carácter invasivo do meio: no momento em que se atenta ao direito ao segredo das comunicações, estas, para serem alvo de interceptações, necessitam de ser comunicações reservadas, fechadas e não públicas”. Cf. Das escutas telefônicas: a monitorização dos fluxos informacionais e comunicacionais. Tomo I, $2^{\mathrm{a}}$ ed., Coimbra: Coimbra Editora, pp. 91-94.

372 GRINOVER, Ada Pellegrini. O regime brasileiro das interceptações telefônicas. In: Revista de Direito Administrativo. vol. 207, janeiro/março 1997, Rio de Janeiro: Renovar, p. 24. Esclarece a autora, ainda, que "é irrelevante indagar a respeito da existência de conhecimento e consentimento de um dos interlocutores. possível que nenhum deles esteja a par da operação técnica, ou que um consinta com ela. Embora a doutrina prefira falar, só no primeiro caso (interceptação executada à revelia de ambos os interlocutores), em interceptação strictu sensu, e, no segundo caso (interceptação conhecida e consentida por um deles), em escuta telefônica, em ambos os casos a terzietà está presente, e tratar-se-á de interceptação subsumível à lei." (cit, p. 24).

373 GRINOVER, Ada Pellegrini; MAGALHÃES GOMES FILHO, Antonio; FERNANDES, Antonio Scarance. As nulidades no processo penal. 12 ed. rev. e atual. São Paulo: RT, 2011, p. 165.

374 SCARANCE FERNANDES, Antonio. A Lei de interceptação telefônica. In: PENTEADO, Jaques de Camargo. (Coord.). Justiça Penal: críticas e sugestões : provas ilícitas e reforma pontual. n. 4. São Paulo: Revista dos Tribunais, 1997, p. 53. 
apuração de outro. Afinal, a proibição da interceptação à margem da lei visa a impedir que a intimidade das pessoas investigadas seja devassada, criando graves danos morais o uso abusivo das informações captadas. ${ }^{375}$

Quando a reportagem jornalística decorreu de informações colhidas através de câmeras ocultas, da "infiltração" do repórter, ou de gravação clandestina de conversas de terceiros, é ilegal e não poderá deflagrar apuração policial de eventual crime.

Todavia, deverá ser analisada em que circunstância ocorreu, por exemplo, a "infiltração" ilegal e, mais do que isso, se é possível aproximar, a figura do jornalista, ao "agente infiltrado", que obtém autorização judicial para a investigação de organização criminosa. ${ }^{376}$ Não prescindir de análise, também, as condições em que ocorreram a captação e a interceptação ambiental, pois essas podem exigir autorização judicial para serem realizadas ${ }^{377} \mathrm{e}$, portanto, o repórter não poderá utilizar-se desse meio de investigação para seu trabalho.

O problema não se resolve tranquilamente. As reportagens jornalísticas, sobretudo as investigativas, não se embasam, única e exclusivamente, em transcrições de interceptações ou escutas ilegais, tampouco nas imagens feitas por câmeras ocultas. Elas são, frequentemente, o resultado de investigações feitas pelos jornalistas, por meio de inúmeras fontes. A final, todos os elementos apurados, com o objetivo de informar o público, interagem e são editados e transformados em uma versão dos fatos. Daí a dificuldade de se estabelecer, no contexto, a informação que se originou do meio ilegal de busca da "verdade" de interesse para a imprensa. E, na maior parte das vezes, é o contexto, a versão editada dos fatos, a "notícia criminis" que dá origem à investigação criminal.

O Supremo Tribunal Federal já entendeu que “[...] reportagem exibida pela TV Globo nos dias 26 e 27 de abril de 2001 constituiu noticia criminis. A autoridade policial tomou conhecimento da prática do delito e foi compelida a agir, sob pena de prevaricação [artigo 119 do CP]. A matéria jornalística não constituiu meio exclusivo de prova, até

375 PRADO, Geraldo. Limites às interceptações telefônicas e a jurisprudência do Superior Tribunal de Justiça. Rio de Janeiro: Lumen Juris, 2005, p. 70.

${ }^{376}$ A Lei $10.217 / 2001$ que alterou os arts. $1^{\circ}$ e $2^{\text {o }}$ da Lei $9.034 / 95$, a Lei do Crime Organizado, permitiu a infiltração de policiais em organizações criminosas para investigações, mediante autorização judicial.

${ }^{377}$ Art. $2^{\circ}$, IV, da Lei 10.217/2001. 
porque sequer constava dos autos quando da abertura da sindicância ou da instrução do inquérito. Logo, as provas que embasaram o inquérito policial não derivaram da reportagem veiculada em rede de televisão, sendo inaplicável à hipótese dos autos a teoria da árvore dos frutos envenenados [the fruits of poisonous tree]. (...) A PGR destacou tão somente - e o acórdão acatou - que a supremacia do interesse público sobre o particular autoriza a relativização do direito à privacidade e à imagem, reafirmando entendimento consagrado na Corte no sentido de que a gravação ambiental - captação de conversa entre presentes - quando praticada ou autorizada por um dos interlocutores, ainda que sem o consentimento do outro, não é ilícita. Trata-se, em verdade, de mecanismo de defesa licitamente utilizado pela vítima. [...]"378.

Se para a obtenção da notícia, o repórter agiu com violação aos direitos da personalidade das pessoas envolvidas, portanto, ilicitamente ${ }^{379}$, não se pode excluir a possibilidade de ponderar os bens em conflito, aplicando-se a regra da proporcionalidade ${ }^{380}$. Em prejuízo do interesse público, não pode um político, um funcionário público que exerce relevante função pública em qualquer dos Poderes da Federação, tentar impedir a investigação de crime no qual ele estaria envolvido, sob o argumento da proteção constitucional da honra, da intimidade ou da imagem.

O tema encontra, ainda, outro elemento complicador, que é a situação segundo a qual, o material informativo publicado pela mídia, mesmo que tenha sido colhido à

\footnotetext{
${ }^{378}$ Supremo Tribunal Federal. Emb. Decl. no Habeas Corpus 87.341-3 Paraná. Relator Ministro Eros Grau, Primeira Turma. D.J. 16.03.2007. No mencionado caso, "o paciente foi denunciado por falsidade ideológica, consubstanciada em exigir quantia em dinheiro para inserir falsa informação de excesso de contingente em certificado de dispensa de incorporação. Gravação clandestina realizada pelo alistando, a pedido de emissora de televisão, que levou as imagens ao ar em todo o território nacional por meio de conhecido programa jornalístico. O conteúdo da reportagem representou notitia criminis, compelindo as autoridades ao exercício do poder-dever de investigar, sob pena de prevaricação. [...] A questão posta não é de inviolabilidade das comunicações e sim da proteção da privacidade e da própria honra, que não constitui direito absoluto, devendo ceder em prol do interesse público. (Precedentes). Ordem denegada". Também o Tribunal de Justiça de São Paulo admitiu o conteúdo de gravação de conversa (gravação ambiental), como prova em ação na qual se pleiteava a cassação de mandado de vereador que exigia dinheiro para alterar lei de funcionamento de casa noturna. Cf, TJSP, Ap. 195.674-5/2, j. 18.12.2002, Relator Desembargador Paulo Travain. RT 815/242.

379 A distinção entre prova ilegal e ilícita é relevante: “ ... a prova é ilegal toda vez que sua obtenção caracterize violação de normas legais ou de princípios gerais do ordenamento, de natureza processual ou material. Quando a proibição for colocada por uma lei processual, a prova será ilegítima (ou ilegitimamente produzida); quando, pelo contrário, a proibição for de natureza material, a prova será ilicitamente obtida". Cf. GRINOVER, Ada Pellegrini e outros. As nulidades...cit., p. 126-127.

${ }^{380}$ Ressalta Nicolas Gonzales-Cuellar Serrano o entendimento da doutrina alemã quanto à função de justiça própria das normas processuais, além da função instrumental em relação ao Direito penal material. Daí a razão pela qual se justifica "a necessária realização de uma ponderação de valores em sua aplicação".Cf. Proporcionalidad y derechos fundamentales em el proceso penal. Madrid: Colex, 1990, p p. 243-244.
} 
margem dos ditames legais, poderá acabar instruindo o inquérito e o processo penal, pois o jornalista não é obrigado a revelar sua origem, uma vez que possui o direito ao sigilo da fonte. Esse aspecto será analisado posteriormente.

O que se infere, até aqui, é que, de um lado, o resultado do jornalismo investigativo contribui para o desenvolvimento democrático e presta um relevante serviço público. Falamos de uma ampla liberdade de imprensa. De outro, o modo ilegal de busca das informações, como na hipótese da utilização de câmeras escondidas, poderá revestir-se de ilicitude e, seu eventual reflexo nas investigações criminais, ou no processo penal, dependerá do Judiciário, que poderá aplicar a regra da proporcionalidade, ponderando os valores em conflito. Por conseguinte, uma notícia adquirida com violação de direitos personalíssimos de um suspeito de delito, poderá, ou não, ser inservível como notitia criminis ou prova no processo penal. 


\section{A PROVA, A BUSCA DA VERDADE NO PROCESSO PENAL E O SEGREDO PROFISSIONAL COMO LIMITE}

\subsection{Garantia e eficiência processuais: a necessária relação com a prova}

O processo penal moderno surgiu como reação à maneira arbitrária e abusiva de o Estado punir os acusados por práticas de crimes, limitando o ius puniendi através de imposição de normas legais. O valor humano era desconsiderado frente à absoluta razão de punir do Estado, mas os ideais iluministas e os que decorreram das revoluções, deixaram o legado da necessidade de barreiras fixadas pelo Direito, para assegurar o respeito à dignidade humana.

A persecução penal do Estado, então, faz-se mediante limites de proteção do acusado em um processo criminal, consistentes na salvaguarda de todos os seus direitos de defesa através de um justo procedimento. a garantia do "princípio da formalidade do procedimento" 381 , tão importante quanto a condenação do culpado e o consequente restabelecimento das ordens jurídica e social.

Para Roxin, a formalidade do procedimento, sem qualquer característica de arbitrariedade, é uma das metas do processo penal, que garante a liberdade do indivíduo acusado de crime e soma-se a sua natureza complexa de estabilidade jurídica da decisão de condenação do culpado, ou proteção do inocente. Daí ser possível afirmar que a ausência de limites para esclarecer os delitos, além de incompatível com o Estado de Direito, destruiria valores não apenas individuais, inerentes à pessoa humana, mas também de toda uma coletividade que legitima a atuação estatal no regime democrático. ${ }^{382}$

\footnotetext{
${ }^{381}$ ROXIN, Claus. Derecho Procesal Penal. Trad. de Gabriela E. Córdoba y Daniel R. Pastor. 25 ed. Buenos Aires: Editores del Puerto, 2003, p. 2. Ressalta-se, aqui, com João Mendes de Almeida Júnior, a distinção entre processo e procedimento:"O processo é uma direção no movimento; o procedimento é o modo de mover e a forma em que é movido o acto [...]. O modo é a delimitação dos princípios productores do acto, quer os materiaes, quer os efficientes; a forma, no procedimento, é a forma extrínseca, que considera o acto já com sua forma intrínseca,[...] Assim, o processo é o movimento em sua forma intrínseca; o procedimento é este mesmo movimento em sua forma extrínseca, tal como se exerce pelos nossos órgãos corporaes e se revela aos nossos sentidos". Cf. Direito judiciário brasileiro. 3 ed., Rio de Janeiro: Freitas Bastos, 1940, p. 264-265.

${ }^{382}$ ROXIN, Claus. Derecho...cit., p.4 e 191.
} 
Não se exclui, no entanto, a possibilidade de surgir uma tensão entre um processo penal garantidor dos direitos fundamentais do cidadão acusado e outro, suficientemente eficaz no enfrentamento de uma nova "criminalidade gravíssima"383, organizada e violenta, que exige uma pronta resposta por parte do Estado. Assim, sendo no procedimento penal "o lugar no qual operam os mecanismos garantísticos previstos para a tutela de tais direitos, poderá haver hipótese na qual, eventualmente, seja necessária a imposição de limites" 384 dos direitos do acusado. O necessário equilíbrio entre tais valores, exigência de garantia pelo Estado democrático, nem sempre fácil de ser alcançado em algumas situações, é um desafio contemporâneo, cuja tarefa é de ser atribuída ao legislador e ao aplicador da lei.

A Constituição brasileira de 1988 delineou os princípios norteadores do processo penal, acentuando as características de um sistema acusatório ${ }^{385}$, dando relevo, sobretudo, a um processo de partes ${ }^{386}$, de efetiva atuação dos intervenientes na produção probatória e na marcha processual. Ressalta-se, portanto, que as partes tiveram reforçadas suas garantias e privilegiou-se um processo penal no qual a sanção só pode ser aplicada se

383 FIGUEIREDO DIAS, Jorge de. O processo penal português: problemas e perspectivas. In: MONTE, Mário Ferreira; CALHEIROS, Maria Clara; MONTEIRO, Fernando Conde; LOUREIRO, Flávia Noversa (Coords.). Que futuro para o direito processual penal? Simpósio em Homenagem a Jorge de Figueiredo Dias, por ocasião dos 20 anos do Código de Processo Penal Português. Coimbra: Coimbra Ed., 2009, p. 809.

${ }^{384}$ GREVI, Vittorio. Alla ricerca di um processo penale "giusto": itinerari e prospettive. Milano: Giuffr , 2000 , p. 13.

${ }^{385}$ Esclarece Jacinto Nelson de Miranda Coutinho que todos os sistemas processuais penais da atualidade, são mistos, não havendo sistema puro, acusatório ou inquisitório. Mas, "os sistemas são mistos não por força da simples somatória dos elementos que os integram mas, fundamentalmente, porque em sendo sistemas regidos pelo princípio inquisitivo, têm agregados a si elementos provenientes do sistema acusatório, como vai suceder com o sistema processual penal brasileiro em vigor e que tem por base o CPP de 1941; ou em sendo regidos pelo princípio dispositivo, têm agregados a si elementos provenientes do sistema inquisitório, como vai suceder com o sistema processual penal norte-americano. [...] a opção, no caso, é política, seja por um ou por outro sistema. Ora, faz-se uma opção política quando se dá a função de fazer aportar as provas ao processo seja ao juiz (como no Sistema Inquisitório), seja às partes, como no Sistema Acusatório, por evidente que sem se excluir (eis por que todos os sistemas são mistos) as atividades secundárias de um e de outros, tudo ao contrário do que se passava nos sistemas puros. Daí que a gestão da prova caracteriza, sobremaneira, o princípio unificador e, assim, o sistema adotado. [...] A Comissão que elaborou o anteprojeto de lei de reforma global do CPP, agora convertido no Projeto n. 156/09-PLS, ao meditar sobre a questão - e como não poderia deixar de ser diante das regras constitucionais - optou pela adoção da base do sistema acusatório e, assim, estabeleceu-se um câmbio epistemológico sem precedentes no país: se aprovado o precitado projeto se terá um Sistema Misto e, deste modo, à base do Sistema Acusatório se agregará elementos provenientes (em menor escala) do Sistema Inquisitório. Mas o sistema de regência será o acusatório; e isso abre novas e melhores perspectivas para a democracia processual." Cf. Sistema Acusatório: cada parte no lugar constitucionalmente demarcado. In: COUTINHO, Jacinto Nelson de Miranda; CARVALHO, Luis Gustavo Grandinetti Castanho de. (Orgs.) O novo processo penal à luz da constituição (Análise crítica do Projeto de lei n. 156/2009, do Senado Federal). Rio de Janeiro: Editora Lumen Juris, 2010, p. 8-9.

${ }^{386}$ Sobre o processo de partes, ver BERTOLINO, Pedro J. El juez de garantias em el código procesal penal de la província de Buenos Aires. Buenos Aires: Depalma, 2000, p. 13 e s. 
precedida do giusto processo ${ }^{387}$. Garante-se, portanto, uma democratização do procedimento penal, com a efetiva interação das partes e um procedimento adequado ao Estado Democrático de Direito, na medida em que se desenvolve com regularidade formal objetivando a justiça das decisões.

Hoje, porém, a questão não se restringe somente ao tema das garantias processuais $^{388}$, mas deve ser preservado, também, o valor da eficiência ${ }^{389}$ da justiça ou do processo penal, ou seja, este deve desenvolver-se com força tal, dentro de limites legais, para tornar eficazes os direitos fundamentais do acusado e, ao mesmo tempo, produzir um efeito, um resultado justo decorrente do ius puniendi estatal. ${ }^{390}$ É, segundo Ennio Amodio, o despertar de uma nova dimensão constitucional do processo, na qual se sintetizam normas garantísticas e de exigências de tutela da coletividade. ${ }^{391}$

Contudo, não é possível admitir a eficiência do processo tão somente numa projeção de "mero instrumento de defesa social", de maior repressão, sem que o seu percurso seja intrinsecamente correto e justo. Assim, "a verdadeira eficiência processual é tal, somente se engloba, também, a eficiência no reconhecimento e no desenvolvimento das garantias processuais",392.

387 Para Giovanni Conso, "Justiça justa quer dizer qualquer coisa mais que justiça, porque justiça justa, processo justo, não são somente a justiça que diz respeito à forma, o processo conforme a lei. Não se trata simplesmente de respeitar as regras. (...) A justiça, o processo devem ser justos não somente no sentido de prescrições que vêm observadas escrupulosamente, mas num sentido mais profundo, de um sistema que deve respeitar os grandes valores e os grandes princípios os quais as normas devem inspirar". Cf. Intervento di Giovanni Conso. In: Il giusto processo. Milano: Giuffrè, 1998, p. 3.

388 Segundo Antonio Magalhães Gomes Filho, há uma dupla dimensão garantista do processo: de ordem pública, "como garantia do correto exercício do poder"; outra possui um perfil subjetivo, "como garantia dos direitos individuais". Cf. A motivação das decisões penais. São Paulo: RT, 2001. p. 26-30.

${ }^{389}$ Segundo Ada Pellegrini Grinover, "o garantismo não colide com a eficiência da justiça penal, mas são valores sobre os quais se sustenta o novo processo penal no mundo inteiro". O que se deve buscar são técnicas que façam do processo um instrumento adequado à realidade aos fins jurídicos, sociais e políticos. Cf. Lineamenti generali del nuovo processo penale in America Latina e punti di convergenza com il modello italiano. CHIAVARIO, Mario (Coord.). Il nuovo codice di procedura penale visto dall estero. Milano: Giuffrè, 1991, p. 142.

390 Sobre a eficiência do processo penal, conceito e teorias, na doutrina se destacam os trabalhos: SCARANCE FERNANDES, Antonio. Reflexões...cit.; PENTEADO, Jacques de Camargo. Duplo grau de jurisdição no processo penal: garantismo e efetividade. São Paulo: Revista dos Tribunais, 2006.

391 AMODIO, Ennio. Processo penale, diritto europeo e common law: dal rito inquisitório al giusto processo. Milano: Giuffrè, 2003, p.36-37.

392 CHIAVARIO, Mario. Garanzie individuali ed efficienza del processo. In: Il giusto processo. Milano: Giuffr , 1998, p. 54. No mesmo sentido, Antonio Magalhães Gomes Filho, o qual ressalta que "a dupla garantia inerente ao processo [...] traz como desdobramento natural a constatação de que a proteção que ela representa seria inócua e ineficaz se a própria estrutura processual não fosse concebida de forma a atingir aqueles mesmos objetivos de correção no exercício do poder estatal e de defesa do indivíduo no confronto com o poder punitivo estatal". Cf. A motivação...cit., p. 30. 
Vê-se, pois, uma imprescindível simbiose entre a eficiência do meio (no processo) e a eficiência do fim (do processo). O procedimento penal, portanto, só é efetivo se se desenvolve com as garantias do justo processo, sem as quais não é possível falar-se em eficiência do ius puniendi estatal o qual objetiva uma ordem legal segura e justa.

A eficiência do processo penal é atingida através da busca da verdade, que é um princípio daquela. ${ }^{393}$ Se a eficiência significa a capacidade de algo ou alguma coisa produzir um determinado resultado, no procedimento criminal ela pode ser entendida como a capacidade de um meio de prova ou meio de busca da prova propiciar a descoberta do fato delituoso. ${ }^{394}$

Todavia, a eficiência não se caracterizará, tão somente, pelo resultado efetivo, do que os meios de prova trouxerem para a investigação ou para a instrução criminal, mas também, pela correção e legalidade na busca das provas, garantindo os direitos da personalidade e processuais do investigado ou acusado, ou até mesmo de terceiros.

O dualismo eficiência-garantia não pode ser esquecido na temática dos meios de provas e meios de busca das provas. Questões éticas e jurídicas que protegem a eficiência das provas devem servir, inclusive, para desmistificar a busca da verdade no processo penal como valor absoluto.

Essa busca da verdade pelas provas, considerada como um dos princípios da eficiência, segundo Jean Pradel, pode ceder em nome da dignidade e direitos fundamentais do indivíduo investigado ou acusado de prática de crime, quando se verificar que o meio para atingi-la só é possível ou for realizado com ofensa a princípios constitucionais.

Mas, se um lado da moeda estampa as garantias do indivíduo, no outro vêm cunhados valores de uma sociedade democrática que também podem prevalecer em relação à eficiência do processo penal quando busca a verdade através das provas. É o próprio Estado de direito limitando o seu poder de concretização das normas punitivas, ajustando,

${ }^{393}$ PRADEL, Jean. Procédure pénale. 10 ed., Paris: Cujas, 2000, p. 300.
${ }^{394}$ SCARANCE FERNANDES, Antonio. Reflexões...cit., p. 25. 
pela normatização da produção probatória a eficiência do processo penal ao valor justiça. ${ }^{395}$

\subsection{Qual a "verdade" buscada no processo penal?}

Sem um conceito definitivo ${ }^{396}$, a verdade pode ser entendida como a conformidade da noção ideológica do intelecto com o real. ${ }^{397}$ De maneira simplista, a busca de uma "verdade" no processo penal corresponde à investigação dos fatos, o mais próximo possível do ocorrido, o mais conforme com a realidade. ${ }^{398}$

Inicialmente, negar a possibilidade de uma verdade processual legitimadora da atividade jurisdicional penal ${ }^{399}$ é negar o próprio processo na sua dimensão de instrumento garantidor da liberdade do acusado, que impede a justiça pelas próprias mãos e o arbítrio da autoridade judiciária diante da pretensão punitiva estatal. ${ }^{400}$

Ora, o processo como limite do poder estatal cumpre a função de garantia da dignidade da pessoa acusada de crime, na medida em que viabiliza a verificação da

\footnotetext{
${ }^{395}$ Assevera Mario Chiavario: “ preciso demonstrar a possibilidade de vencer o desafio contra a criminalidade organizada sem renunciar ao compromisso de proteger as garantias essenciais do homem sob processo. (...) Trata-se de uma aposta na civilização demonstrar que a verdade pode ser perseguida e quase sempre alcançada por métodos ortodoxos sob o ângulo de respeito à pessoa e aos seus direitos fundamentais. Ou seja, trata-se de demonstrar que esses métodos não visam necessariamente a desviar a verdade formal de um objetivo o mais plenamente conforme à verdade real . Cf. O processo penal na Itália: um pós-reforma tumultuado. In: DELMAS-MARTY, Mireille (Org.). Processo penal e direitos do homem: rumo à consciência européia. Tradução Frenando de Freitas Franco. Barueri, SP: Manole, 2004, p. 56.

396 Sobre o sentido filosófico de verdade, Cf. HABERMAS, Jürgen. Verdade e justificação: ensaios filosóficos. Tradução de Milton Camargo Mota. São Paulo: Loyola, 2004, p. 63 e sgts.

${ }^{397}$ MALATESTA, Nicola Framarino Dei. A lógica das provas em matéria criminal. Tradução: Paulo Capitanio. Vol. I, Brasil: Bookseller, 1996, p. 21. Ver também, BARROS, Marco Antonio. A busca da verdade no processo penal. $2^{\mathrm{a}}$ ed., rev. atual. São Paulo: Revista dos Tribunais, 2010, pp. 25-26. ; Para Gustavo Henrique Righi Ivahy Badaró, "o conceito de verdade é um conceito de relação. Um conhecimento é verdadeiro, quando há concordância entre o objeto e a sua imagem captada pelo sujeito. A verdade é o reflexo fiel do objeto da mente, é a adequação do pensamento com a coisa". Cf. Ônus da prova no processo penal. São Paulo: Revista dos Tribunais, 2003, p. 25.

398 Nicolás Guzmán opta pela teoria da verdade como correspondência. Cf. La verdad em el proceso penal. Una contribuición a la epistemologia jurídica.Tradução de Pablo Eiroa. Buenos Aires: Editores del Puerto, 2006, cap.I.

${ }^{399}$ MAGALHÃES GOMES FILHO, Antonio. Direito à prova...cit., p. 54.

${ }^{400}$ No sentido de que uma das funções do processo penal é a proteção do acusado, que deve ser presumido inocente até sentença final transitada em julgado, VALLEJO, Manuel Jaén. Derechos procesales fundamentales: su proyección en la fase de instrucción, em el juicio oral y em el sistema de recursos. In: ALFARO, Luis Miguel Reyna; AROCENA, Gustavo A., SALGADO, David Cienfuegos (Coords.). La prueba, reforma del proceso penal y derechos fundamentales. Lima, Peru: Jurista Editores, 2007, p. 33.
} 
ocorrência, ou não, do fato a ela imputado. O processo, portanto, é instrumento de realização da justiça pela sentença ${ }^{401}$ - sua "aspiração finalística" - a qual possui uma conexão indissolúvel do acertamento da verdade. A verificação dessa é, assim, conditio sine qua non de uma "decisão justa"402, constitui o pressuposto de uma sentença condenatória ou absolutória que incide sobre as liberdades fundamentais da pessoa julgada.

Partiremos, portanto, da afirmação de que a busca da verdade no processo penal é necessária e realizável e dela não se pode abrir mão, sob pena de a atividade jurisdicional não se legitimar através de uma sentença justa. ${ }^{403}$

A verdade que se busca no processo penal, no entanto, é aquela necessária para o correto acertamento dos fatos. Trata-se de uma verdade possível ${ }^{404}$, não absoluta, pois, de modo algum - com o processo ou por qualquer outro meio - poderá ser atingida pelo homem. $^{405}$

A reconstrução verdadeira dos fatos ${ }^{406}$ não é aquela que corresponde, efetivamente, à realidade, pois se aqui encontra a verdade, ela jamais será conhecida em absoluto, na sua inteireza. Não significa, também, que será conhecida parcialmente, pois “a verdade está no todo, não na parte; e o todo é demais para nós"407.

401 Diz Luigi Ferrajoli: “ ... as sentenças - e só as penais - consistem em comprovações de violações à lei. Por isso, exigem uma motivação fundada sobre os argumentos cognoscitivos de fato e re-cognoscitivos de direito, de cuja aceitação como verdadeiros depende tanto sua validade ou legitimação jurídica, como sua justiça ou legitimação política. Sobre este caráter tendencialmente cognoscitivo e não puramente potestativo da jurisdição, se baseiam todas as garantias penais e processuais, do processo correto”. Cf. Prólogo da obra de GUZMÁN, Nicolás. La verdade en el proceso penal: una contribuición a la epistemologia jurídica. Buenos Aires: Editores del Puerto, 2006, I.

${ }^{402}$ COMOGLIO, Luigi Paolo. Le prove civili. $3^{\mathrm{a}}$ ed., Torino: UTET, 2010, p. 21. No mesmo sentido, Enrico Tullio Liebman, para quem não há justiça se não fundada sobre as verdades dos fatos aos quais se refere. Cf. Manuale di diritto processuale civile. 4. ed., Milano: Giuffrè, 1984. v. II. p. 68.

${ }^{403}$ Cf. MAGALHÃES GOMES FILHO, Antonio. Direito à prova ... cit.,p. 54.

${ }^{404}$ Diz Pedro J. Bertolino que a única verdade possível ao homem é a jurídica enquanto resultado do processo.O fato que se reconstruiu por meio do processo, seja qual for o resultado, é a verdade processual, cuja transcendência é impossível. Cf. El debido proceso penal. Buenos Aires: Platense, 1986, p. 141.

${ }^{405}$ CARNELUTTI, Francesco. Verdade, dúvida e certeza. Trad. Eduardo Cambi. In: GENESIS. Revista de direito processual civil, Curitiba, n. 9, jul./set. de 1998, p. 606.

${ }^{406}$ Segundo Michele Taruffo, há duas concepções sobre a verdade no processo penal: uma diz respeito à reconstrução judicial dos fatos, "segundo a qual o juiz acerta o verdadeiro quanto mais seu conhecimento se aproxima da efetiva realidade histórica dos facta probanda. A outra ideia de verdade, mais difundida na doutrina norte-americana, preocupa-se mais com o método processual empregado para acertar os fatos. Nessa perspectiva, "a verdade é por definição aquilo que se consegue com o uso correto do instrumento processual melhor “. Cf. Il processo civile adversary nell'esperienza americana. Padova: CEDAM, 1979, p. 47-48.

${ }^{407}$ CARNELUTTI, Francesco. Verdade...cit., p. 607. 
Mas se a imposição de uma sanção decorre, no processo penal, de uma "reconstrução retrospectiva de um evento real" ${ }^{408}$ dentro de critérios e limites legais, a verdade que se obtém é a processual, não aquela averiguada a qualquer preço, mas conforme o devido processo legal (art. 5 LV, CF). E, sobretudo, sem avançar nos direitos e garantias individuais.

Logo, o que se produziu no processo, por meio de provas, em observância às normas estabelecidas pelo Estado de Direito, corresponde à verdade do fato, à verdade processual, mais próxima, mais exata possível da realidade, da reconstituição dos fatos ${ }^{409}$. Trata-se, no entanto, de uma verdade relativa, ${ }^{410}$ porque as provas que vão sustentar a decisão judicial são "instrumentos não absolutos" "411 de reconstrução verdadeira dos fatos pelo juiz. Cabe afirmar, então, que no processo penal só podem ser considerados verdadeiros os fatos conhecidos e provados nos limites dos princípios garantidores dos direitos do acusado.

Não há dúvidas, porém, de que a busca do conhecimento do fato com limites processuais estabelecidos pela sociedade, "tem um preço a ser pago pela democracia"412, que pressupõe, "algumas vezes, o sacrifício da verdade"413. No entanto, conforme entendimento de Luigi Ferrajoli, nessa verdade processual buscada e comprovada por meios e provas corretos, condicionados a procedimentos próprios e em respeito às garantias da defesa; nessa verdade que vai fundamentar a sentença penal, reside o valor do "formalismo" que protege a liberdade do acusado "contra a introdução de verdades

\footnotetext{
${ }^{408}$ BAPTISTA, Francisco das Neves. O mito da verdade real na dogmática do processo penal. Rio de janeiro: Renovar, 2001, p. 67.

${ }_{409}$ KARAN, Maria Lúcia. Sobre o ônus da prova na ação penal condenatória. Revista Brasileira de Ciências Criminais 35/57, São Paulo: RT, jul.-set. 2001.

${ }^{410}$ Verdade relativa é "o juízo resultante do confronto da afirmação da ocorrência do fato, pelas partes, com a demonstração da sua ocorrência pelo juiz, através das provas produzidas no processo." Cf. CAMBI, Eduardo. Verdade processual objetivável e limites da razão jurídica iluminista. Revista de Processo 96/232249, São Paulo: RT, out.-dez. 1999, pp. 243-244.

${ }^{411}$ TARUFFO, Michelle. Conocimiento científico y critérios de la prueba judicial. Tradução de Lucas Correa Montoya. In: _ _ CARVAJAL, Diana Ramírez. Conocimiento, prueba, pretensión y oralidad. Lima, Peru: ARA Editores, 2009, p. 17.

${ }^{412}$ COUTINHO, Jacinto Nelson de Miranda. Glosas ao "Verdade, Dúvida e Certeza", de Francesco Carnelutti, para os operadores do Direito. In: Revista de estudos criminais. Ano 4, Rio Grande do Sul, 2004, n. 14 , p. 80.

${ }^{413}$ SILVA, Germano Marques da. Curso de processo penal. , 4 ed. rev. atual. Lisboa, Portugal: VERBO, 2000 , v. I, p. 86.
} 
substanciais tão arbitrárias quanto incontroláveis". ${ }^{414}$ E nessa perspectiva formal da verdade é possível entender que as garantias constitucionais processuais, "além de garantias de liberdade, são também garantias de verdade ${ }^{\text {415. }}$.

A refutação da ideia de uma lógica inquisitiva, no sentido de que a verdade material $^{416}$ deve aparecer por inteira, completa, absoluta, não significa a renúncia ao valor verdade, pois necessário para uma decisão justa. ${ }^{417}$ Ao contrário, é preciso verificar as hipóteses da acusação por meio de provas e possibilitar a efetiva contrariedade da defesa para que haja uma comprovação imparcial da verdade processual. ${ }^{418}$

\subsection{A busca da verdade pela prova}

Falar da verdade no processo é falar de prova. Os conceitos estão, necessariamente, conectados um ao outro e são interdependentes. A pretensão de uma verdade no direito

\footnotetext{
${ }^{414}$ FERRAJOLI, Luigi. Derecho y razón. Teoria del garantismo penal. Trad. Perfecto Andrés Ibáñez et al. Madrid: Trotta, 1997, p. 45.

${ }^{415}$ FERRAIJOLI, Luigi. Derecho y razón...cit., p. 46.

${ }^{416}$ Aqui, o termo "verdade material" está empregado no seu sentido doutrinário clássico como princípio da investigação probatória em razão do qual "o juiz vela pela conformidade da postulação das partes com a verdade real, a ele revelada pelos resultados da instrução criminal. (...) as partes no processo penal, achavamse vinculadas por tal forma à verdade material, que ao juiz, e não a elas, é que incumbia definir, segundo sua conviç̧ão, os termos da questão, como deveriam postular-se, e os meios de prova, como haveriam de ser produzidos" (Cf. BARROS, Marco Antonio de. A busca da verdade...cit., p. 37). O modo ilimitado de ação do juiz, era o que caracterizava a busca da "verdade material". "A liberdade do juiz penal foi vista como instrumento essencial para a realização da pretensão punitiva do estado: o juiz penal, diversamente do juiz civil, deveria ser dotado de poderes ilimitados, para efeito de acertamento dos fatos, porque a descoberta da verdade, obtida de qualquer forma, é a premissa indispensável para alcançar o escopo da defesa social . E é assim que a busca da verdade se transmudou num valor mais precioso do que a proteção da liberdade individual" (Cf. GRINOVER, Ada Pellegrini; MAGALHÃES GOMES FILHO, Antonio; SCARANCE FERNANDES, Antonio. As nulidades no processo penal. 11 ed., rev. atual. São Paulo: Revista dos Tribunais, 2009, p. 123). Mister anotar, porém, que a "verdade material" como liberdade absoluta do juiz penal é um equívoco. No sentido correto, "de um lado, no sentido da verdade subtraída à influência que as partes, por seu comportamento processual, queiram exercer sobre ela; de outro lado, no sentido de uma verdade que, não sendo absoluta ou ontológica, há de ser antes de tudo uma verdade judicial, prática e, sobretudo, não uma verdade obtida a todo preço: uma verdade processualmente válida" (Cf. GRINOVER, Ada Pellegrini e outros. As nulidades...cit., p. 123). Possível dizer, então, que no processo penal busca-se uma "verdade material" dentro de critérios formais - normas processuais constitucionais - garantidores da liberdade do indivíduo: "verdade processual".

${ }^{417}$ Nesse sentido: MUÑOZ CONDE, Francisco. Búsqueda de la verdad em el proceso penal. Buenos Aires: Hammurabi, 2000, p. 97.

${ }^{418}$ Eliomar da Silva Pereira reconhece um nexo entre verdade e validade jurídica dos meios utilizados para a investigação dos fatos delituosos. Esclarece que, embora o método de investigação válido limite a busca da verdade "permite legitimá-la pelo respeito a certos valores relacionados a tais limites jurídicos". Cf. O problema da verdade na investigação criminal. In: Revista Brasileira de Ciências Criminais. São Paulo, Ano 19, vol. 91, jul./ago de 2011, p.112.
} 
está ligada, de um modo inseparável, à necessidade de legitimação da decisão judicial ${ }^{419}$, ou seja, de uma autoridade que a torne aceita socialmente, "independente do uso da força" ${ }^{\text {420 }}$. Segundo Erich Döhring, há uma tendência mundial da opinião pública no sentido de exigir que os esclarecimentos dos fatos cheguem a um resultado não apenas aparente mas à "realidade mesma"421.

Para tanto, a busca da verdade processual, legitimadora do convencimento do magistrado, só é possível através das provas que servirão para reconstruir e demonstrar os fatos. ${ }^{422}$ Portanto, a prova é necessária para o acertamento dos fatos, para "estabelecer a verdade dos fatos"

Mas, diante da impossibilidade de se atingir a "verdade", no sentido de absoluta correspondência com a realidade, o entendimento deve ser aquele, segundo o qual, a prova é dirigida e tem o escopo de formar a convicção do julgador acerca dos fatos. Dela dependerá - porque é pressuposto fundamental - a aceitação da verdade ou falsidade do fato em julgamento.

A prova judiciária tem a função, portanto, de estabelecer a certeza ${ }^{425}$ na mente do juiz sobre a ocorrência, ou não, de determinados fatos ${ }^{426}$, para que possa proferir uma

${ }^{419}$ NEUMANN, Ulfried. La pretensión de verdad en el derecho y tres ensayos sobre Radbruch. Trad. Mauricio Hernández. Colombia: Universidad Externado de Colombia, 2006, p. 13.

${ }^{420}$ FARIA, José Eduardo. Poder e legitimidade. São Paulo: Perspectiva, 1978, p. 80-81.

${ }^{421}$ Para o autor, "Hoje se espera, mais do que em décadas anteriores, que a averiguação se valha de todos os meios lícitos que possam servir de algum modo para o esclarecimento". E esclarece haver uma tendência nas jurisprudências alemã e francesa de abrandar o rigor probatório, sobretudo no que respeita aos depoimentos das testemunhas que podem se escusar de depor. A ideia é de chegar à comprovação dos fatos com mais segurança, próximo da "realidade", tudo em nome da verdade. Todavia, necessário que se diga, sem se afastar dos limites legais na produção probatória. Cf. La Prueba. Buenos Aires: Valleta, 2003, p. 17-18.

${ }_{422}$ Segundo Gaetano Foschini, usualmente se fala de reconstrução do fato que significa uma "construção com a qual se deve fazer voltar a ser alguma coisa que já foi antes. E é assim, porque a construção que cabe à função judiciária diz respeito a um fato passado." Cf. Sistema del diritto processuale penale. 2 ed., Milano: Giuffrè, 1965, p. 494.

${ }^{423}$ MAGALHÃES GOMES FILHO, Antonio. Direito à prova...cit., p. 42.

${ }^{424}$ ROSA, Inocêncio Borges da. Processo penal brasileiro. Porto Alegre: Globo, 1942, v. 1, p. 381.

${ }^{425}$ Para Francesco Carnelutti, a certeza não pertence ao reino do pensamento, é ação, implica uma escolha cernere é separar, escolher, optar após avaliação. O juiz deve condenar, ou absolver, porque deve agir. Não é apenas um juízo, é uma ação. E a ação tem seu ciclo que se inicia e termina com a fé. Cf. Verdade, ... cit., p. 607.

${ }^{426}$ Nesse sentido, TARUFFO, Michele. La prova dei fatti giuridici. Milano: Giuffrè, 1992, p. 1. 
sentença certa e justa. Essa certeza, não é a objetiva e absoluta, mas a prática, essencialmente relativa, decorrente do convencimento judicial. ${ }^{427}$

Possível falar-se, então, de uma função pública da prova, na medida em que serve ao Estado no seu poder de dizer o direito e, ao mesmo tempo, protege os cidadãos de uma restrição arbitrária do valor liberdade ${ }^{428}$ no processo penal, pois seu exame vai servir para a motivação da decisão judicial - garantia assegurada pela Constituição de 88 (art. 93,IX) -, "que se expande no domínio da consciência social através dos diversos órgãos de controle de que dispõe a sociedade." 429

\subsection{Prova e meios de prova: definição}

O termo prova ${ }^{430}$, inicialmente, pode ser considerado como "instrumento"431 utilizado para verificar a comprovação de um fato, segundo as regras de um "justo processo". É também, um "procedimento" através do qual se pretende chegar à comprovação da existência de um fato histórico.

Importante esclarecer, nesse ponto, que embora na linguagem jurídica seja comum a referência à "prova de um fato", o fato é ou não é, ele simplesmente existe e não se prova sua veracidade ou falsidade. O que se prova são os "enunciados factuais" ou afirmações sobre o fato. Falso ou verdadeiro poderá ser o enunciado sobre o fato, mas não o fato em si. $^{432}$

No sentido etimológico, provar, deriva do verbo probare- (probo, as, are) (examinar, demonstrar); vem de probus (bom, honrado); indica uma atividade do espírito dirigida à verificação de um juízo. ${ }^{433}$ Segundo Cândido Rangel Dinamarco ${ }^{434}$, probus

\footnotetext{
${ }^{427}$ FOSCHINI, Gaetano. Sistema...cit., p. 405.

${ }^{428}$ ECHANDDÍA, Hermando Devis. Teoría general de la prueba judicial. 5 ed., Bogotá-Colombia: TEMIS, 2002, t. I, p. 111.

${ }^{429}$ FLORIAN, Eugenio. Delle prove penali. Milano: Istituto Editoriale Cisalpino, 1961, p. 25.

${ }^{430}$ Sobre a elaboração do conceito de prova cf. MASSA, Michele. Contributo all'analisi del giudizio penale di primo grado. Milano: Giuffrè, 1964, p. 63 e sgts..

431 SIRACUSANO, Delfino. Prova: (III) Nel nuovo códice di procedura penale. Enciclopedia Giuridica, Roma, 1992, t. I, p. 1.

${ }^{432}$ UBERTIS, Giulio. Il processo penale.Bologna: Il Mulino, 2008, p.23.

${ }^{433}$ CARNELUTTI, Francesco. Sistema de derecho procesal civil, Padova: Cedam, 1963, v. 1, p. 674.
} 
"significa idôneo, correto, verdadeiro", razão pela qual "a atividade probatória que se realiza no processo visa a demonstrar que as alegações feitas são verdadeiras e, portanto, dignas de credibilidade no momento de julgar".

Essa é a acepção do termo prova como demonstração, ou seja, capaz de estabelecer a verdade de um fato. Assim, provar é a conduta de afirmar ou negar a veracidade de um fato, por meio de elementos idôneos de informação. ${ }^{435}$

$\mathrm{Na}$ terminologia processual, fala-se em elemento de prova como cada dado objetivo que confirma ou nega uma asserção referente a um fato, como, por exemplo, a declaração de uma testemunha. ${ }^{436}$

A testemunha, no entanto, é uma fonte pessoal de prova, assim como o documento também é fonte de prova, porém, real. Fonte de prova indica elementos vários os quais, em princípio, estão desvinculados do processo e a eles poderão, ou não, ser introduzidos. É uma pessoa ou coisa, com existência que precede ao processo. A condução da fonte ao processo se dá por via, por meios de prova, ${ }^{437}$ através de uma atividade desenvolvida com ampla e efetiva participação das partes - princípio do contraditório - perante o juiz.

Assim, o "instrumento processual que permite a aquisição de um elemento de prova", ou através do qual as informações ou conhecimento acerca de um objeto de prova são introduzidos no processo é meio de prova ${ }^{438}$.

${ }^{434}$ In: Instituiç̃ões de direito processual civil. São Paulo: Malheiros, 2001. vol. II. p. 611.

${ }^{435}$ MAGALHÃES GOMES FILHO, Antonio. Notas sobre a terminologia da prova (reflexos no processo penal brasileiro). In: YARSHELL, Flávio Luiz; MORAES, Maurício Zanoide de (Orgs.). Estudos em homenagem à professora Ada Pellegrini Grinover. São Paulo: DJP, 2005, p. 305. No mesmo sentido: TUCCI, Rogério Lauria. Curso de direito processual civil. vol. 2, São Paulo: Saraiva, 1989, p. 337.

${ }^{436}$ MAGALHÃES GOMES FILHO, Antonio. Notas...cit., p. 307.

${ }^{437}$ CARBONE, Carlos Alberto. Grabaciones, escuchas telefônicas y filmaciones como médios de prueba. Santa Fe, Argentina: Rubinzal-Culzoni, 2005, p. 88

${ }^{438}$ TONINI, Paolo. A prova no processo penal italiano. Tradução Alexandra Martins e Daniela Mróz. São Paulo: Revista dos tribunais, 2002, p. 108. Segundo Antonio Magalhães Gomes Filho, os meios de prova são "os canais de informação de que se serve o juiz. Assim, quando se fala em prova por testemunho ou prova documental, indica-se que a representação do fato foi conseguida por meio do testemunho ou do documento." Cf. Notas...cit., p. 308-309. Santiago Sentis Melengo esclarece que "meios são as atuações judiciais com as quais as fontes se incorporam no processo .[...] A coisa que vai ser examinada é a fonte, o reconhecimento pelo juiz é um meio". Para o autor, a importância da distinção não é meramente teórica, pois as fontes pertencem aos litigantes, enquanto que os meios são dirigidos ao juiz. Cf. La prueba. cit., p. 16. 
Portanto, os conceitos encadeiam-se no seguinte sentido: "a prova é a verificação de afirmações [...] que se realizam utilizando fontes as quais se levam ao processo por determinados meios"439 constituindo, necessariamente, "meios de produção da certeza"440. Frise-se, no entanto, que os meios de prova, quando relevantes e admissíveis, nem sempre supõem a prova (no sentido de resultado) dos fatos. Sob essa ótica, esses meios de prova são a base nos quais se apóia, nos quais se fundamenta a verdade judicial dos fatos, e que resulta de inferências racionais feitas pelo juiz. ${ }^{441}$

Finalmente, mister esclarecer a diferença entre meios de prova e meios de busca, de investigação das provas, ou meios de obtenção da prova, o que foi feito pelo Código de Processo Penal italiano, nos títulos II e III, respectivamente.

Os mezzi di ricerca della prova (inspeções, interceptações de conversas telefônicas, busca e apreensões etc.) não são, em si mesmo, fontes de convencimento judicial, mas possibilitam, instrumentalizam a obtenção dos meios de prova. Podem ser entendidos como procedimentos técnico-operativos, disciplinados por lei, realizados, sobretudo, na fase do inquérito policial, para obter meios de prova (a interceptação das conversas telefônicas é meio de obtenção de prova; as gravações realizadas são meio de prova). ${ }^{442}$

\subsection{Procedimento e proibição de prova: limites à verdade}

O limite à prova pressupõe uma restrição à apuração da verdade e, por vezes, um limite a um direito à prova reconhecido às partes no processo. ${ }^{443}$

\footnotetext{
${ }^{439}$ MELENDO, Santiago Sentis. La prueba. cit., p. 16.

${ }^{440}$ MITTERMAIER, Karl Joseph Anton. Tratado de la prueba em matéria criminal. Traducción de Primitivo González del Alba. Buenos Aires: Hammurabi, 2006, p. 135.

${ }^{441}$ TARUFFO, Michele. La prueba. Trad. Laura Manríquez y Jordi Ferrer Beltrán.. Madrid: Marcial Pons, 2008 , p. 35

${ }^{442}$ SILVA, Germano Marques da. Curso de processo penal. 2 ed., rev. atual., Lisboa:VERBO, 1999, v. II, p. 190.

${ }^{443}$ Vitorio Grevi ressalta que, em muitos casos, o limite à prova significa uma restrição ao direito de defesa do acusado, "se por certo se houver que uma das formas mais positivas da exteriorização desse direito é a de defender-se provando". Cf. O segredo como limite à prova no processo penal italiano. Trad. de Roberto Orlando Pucci. Ciência Penal, Ano II, n. 4, São Paulo: Convívio, 1975, p. 3.
} 
A reflexão feita sobre a verdade processual, como a única possível para se atingir a justiça das decisões judiciais, remete-nos para o campo da forma de se provar os fatos. Sim, pois o juiz e as partes não podem valer de qualquer meio de obtenção da verdade, devendo submeter-se às normas regulamentadoras das formas de produção probatória no processo penal.

Cumpre mencionar, primeiramente, que a doutrina costuma fazer uma analogia entre as atividades realizadas pelo juiz e pelo historiador. ${ }^{444}$ Ambos, com o auxílio das provas, procuram reconstruir acontecimentos do passado aproximando-os, no presente, da realidade. Entendemos possível a extensão da analogia para o trabalho que é realizado pelo jornalismo investigativo. Assim como o historiador e o juiz, o jornalista também busca descobrir a verdade do fato, objeto de notícia, através dos mesmos meios de investigação daqueles profissionais.

Em todos esses campos que têm a investigação da verdade como instrumento de trabalho, verifica-se que as tarefas são afins, mas enquanto o historiador e o jornalista possuem ampla liberdade de pesquisa sobre os fatos passados, o juiz, ao contrário, já encontra limites em normas jurídicas que regulam a forma de seu agir e que "definem o contexto da verdade judicial". ${ }^{445}$ Segundo Michele Taruffo ${ }^{446}$, não existem diferenças substanciais na forma e no meio empregado para se alcançar a verdade no campo judicial, histórico ou extra-judicial. Nesses contextos, os meios que se empregam para descobrir a verdade são os mesmos, ou seja, os testemunhos, as gravações, os documentos, entre outros.

A distinção entre os trabalhos do historiador, do jornalista e do juiz, encontra-se, fundamentalmente, nos métodos ${ }^{447}$ utilizados para colher o material informativo, avaliá-lo e utilizá-lo para o fim proposto. Os dois primeiros, com ampla liberdade de atuação, criam

444 Ver: CORDERO, Franco. Il procedimento probatório. In: Tre studi sulle prove penali. Milano: Giuffrè, 1963, p. 30, nota 80; MAGALHÃES GOMES FILHO, Antonio. Direito à prova...cit.,pp.4445.

445 TARUFFO, Michele. La prueba...cit., p. 25.

446 TARUFFO, Michele. La prueba...cit., p. 25.

${ }^{447}$ Esclarece Antonio Magalhães Gomes Filho que "o método probatório judiciário constitui, na verdade, um conjunto de regras mais amplo, cuja função garantidora dos direitos das partes e da própria legitimação da jurisdição implica limitação ao objeto da prova, aos meios através dos quais os dados são introduzidos no processo, além de estabelecer os procedimentos adequados às operações relacionadas à colheita do material probatório, ou mesmo, em certas situações, o valor da prova obtida". Cf. Direito à prova...cit., p. 92. 
modos, estratégias próprias de pesquisas sobre os fatos, suficientes para alcançarem a sustentação do que pretendem publicar como ciência ou informação midiática, podendo valer-se, inclusive, “de impressões pessoais ou intuições na descoberta do verdadeiro" ${ }^{448}$.

O juiz, no entanto, submete-se a procedimento legal regulatório da forma pela qual os fatos podem ser provados, que impõe limites à busca da verdade. Assim, as regras que disciplinam e limitam a atuação do magistrado dizem respeito à atividade probatória, como a necessidade de as provas serem produzidas com observância do contraditório ${ }^{449}$ - com a ampla atuação e igual oportunidade às partes -, na impossibilidade de utilização de provas ilícitas, na proibição do depoimento de algumas pessoas, entre outros obstáculos existentes para a averiguação da verdade processual.

Da observância do contraditório como forma legal de produção probatória, decorre um "direito à prova" 450 dos sujeitos processuais, o que significa dizer que a eles é garantido introduzir, produzir provas com o fim de demonstrar a verdade das suas versões acerca dos fatos. ${ }^{451}$ É a possibilidade, no sistema acusatório, de as partes buscarem as provas, obterem a admissão dos meios de prova, participarem da produção dos meios de prova e apresentarem uma valoração dos elementos probatórios. ${ }^{452} \mathrm{E}$, no que concerne à produção probatória, as partes podem inquirir testemunhas, solicitar perícia etc., visando a comprovar suas versões sobre os fatos ${ }^{453}$ e terem a possibilidade de influenciar o convencimento judicial.

\footnotetext{
${ }^{448}$ MAGALHÃES GOMES FILHO, Antonio. Direito à prova...cit., p. 45.

${ }^{449}$ Anota Nicolo Troc er, que na Itália e na Alemanha, "o melhor critério e a via mais segura para se chegar à verdade e à justiça é através do contraditório e do diálogo com as partes". Cf. Processo civile e costituzione (problemi di diritto tedesco e italiano). Milano: Giuffrè, 1974, p. 646.

${ }^{450}$ Paolo Tonini afirma que "o direito à prova é uma expressão sintética que compreende o direito de todas as partes de buscar as fontes de prova, requerer a admissão do respectivo meio, participar de sua produção e apresentar uma valoração no momento das conclusões". Cf. A prova...cit., p. 83.

${ }^{451}$ Ennio Amodio, analisando a reflexão de Damaska sobre os sistemas de justiça penal modelados por diferentes estruturas de poder, ressalta o "contraste entre regras probatórias impostas nos respectivos âmbitos. No rito acusatório assume uma posição central de iniciativa contraposta das partes na aquisição e elaboração da prova diante do juiz. No processo inquisitório, ao contrário, a prova é do juiz, uma vez que ele tem o dever de buscar a verdade também no caso de inércia das partes". Cf. Il diritto delle prove penali nel pensiero di Mirjan Damaska. In: Rivista italiana di diritto e procedura penale. Anno L, fasc. 1, gennaiomarzo 2007, Milano: Giuffrè, p. 12.

${ }_{452}$ TONINI, Paolo. A prova ....cit., pp. 84-86.

453 , segundo Antonio Magalhães Gomes Filho, a "dimensão positiva" do direito à prova. Cf. Direito à prova...cit., p. 83.
} 
Essa atividade das partes é limitada por barreiras que se constituem em valores tutelados pelo ordenamento jurídico, os quais também devem ser garantidos. É o que ocorre quando o Código de Processo Penal, com o intuito de proteger os direitos fundamentais do ser humano, à intimidade e vida privada, proíbe de depor "as pessoas que, em razão de função, ministério, ofício ou profissão, devam guardar segredo, salvo se, desobrigados pela parte interessada, quiserem dar o seu testemunho" (art. 207).

Há, portanto, uma proibição de prova, um impedimento legal de averiguar fatos que constituem o objeto do processo penal. Entendida como "regra que proíbe converter o fato em objeto de acusação e do procedimento" ${ }^{\text {454 }}$, as proibições de prova são efetivos limites à descoberta da verdade, são “... limitações auto impostas ao conhecimento. Trata-se daqueles casos os quais não se deve provar, e não os quais não se pode provar, ${ }^{\natural 55}$.

A proibição de prova contida em todos os ordenamentos jurídicos penais fundamenta-se no Estado de Direito que, se de um lado tem interesse num processo penal efetivo, de outro, assiste-lhe o dever de respeitar e proteger os direitos pessoais dos indivíduos. Daí resulta que a averiguação e penalização dos fatos puníveis, não obstante de suma importância, não podem ser obtidos sem limites jurídicos e, "não pode constituir sempre e sob qualquer circunstância, interesse prevalente do Estado" "456. Para solucionar o conflito de interesses entre Estado e indivíduo, surge, então, a proibição de prova com a missão de tutelar os direitos individuais frente ao ius puniendi estatal.

\subsection{Segredos profissionais e religiosos como limites à prova: fundamentos.}

O sistema processual que determine o segredo como limite à investigação probatória, tal como se dá com a prescrição do art. 207 do Código de Processo Penal brasileiro, relativiza os valores da apuração da verdade - e, por consequência, da

${ }^{454}$ GÖSSEL, Karl Heinz. La busqueda de la verdad...cit., p. 678.

455 BELING, Ernst Von. Las prohibiciones de prueba como limite a la averiguación de la verdad em el proceso penal. In: ; AMBOS, Kai; GUERRERO, Óscar Julián. Las prohibiciones probatórias. Bogotá, Colombia: Editorial TEMIS S.A., 2009, p. 6.

${ }^{456}$ Decisão da jurisprudência alemã citada por Karl Heinz Gössel. Cf. La busqueda de la verdad em el proceso penal. Aspectos jurídico-constitucionales y político-criminales. Trad. Miguel Polaino Navarrete. In: Cuadernos de política criminal. n. 45, Madrid: EDERSA, 1991, p. 677. 
efetividade do processo - e do direito à prova das partes, preferindo outros bens que são protegidos pelos segredos profissionais e religiosos. ${ }^{457}$

Trata-se de uma ponderação de valores feita pelo legislador, de um equilíbrio entre interesses em jogo, decorrente da necessidade de tutela das relações profissionais, consideradas úteis para a convivência social. À comunidade interessa o bom funcionamento de alguns serviços, o que só é possível quando há relação de confiança entre o cliente e alguns profissionais, como o médico, advogado etc., e o cidadão sabe que seus interesses e segredos individuais não serão revelados, nem mesmo em juízo. ${ }^{458}$

Ao vedar a prova nos casos em análise, optou o legislador pela garantia do pleno exercício da profissão ou função, por assegurar valores constitucionais como a intimidade e a privacidade dos cidadãos que dependem dos profissionais "qualificados" ${ }^{459}$, e permitir a realização plena dos direitos à saúde, ao acesso à justiça, e a professar a fé religiosa, tudo em detrimento da verdade processual. ${ }^{460}$

Portanto, os segredos ${ }^{461}$ profissionais, ou seja, aqueles que não devem ser revelados por quem os detêm, são meios processuais impostos para a tutela de interesses ou "valores extraprocessuais" $" 462$, como os direitos materiais ${ }^{463}$, os "interesses individuais da preservação de segredo sobre determinados fatos" $" 464$ e valores de índole "supra-individual que é a confiança sobre que deve assentar o exercício de certas profissões" 465 .

\footnotetext{
${ }^{457}$ Nesse sentido, GREVI, Vittorio. O segredo...cit., pp. 3-4.

${ }^{458}$ Ressalta Paolo Tonini, que "as necessidades da vida social levam a pessoa, com o objetivo de tutelar seus próprios interesses, a procurar profissionais dotados de conhecimentos específicos, podendo o indivíduo, ao fazê-lo, revelar informações sigilosas". Cf. A prova...cit., p. 132.

459 Paolo Tonini define como "qualificado" o segredo das pessoas cujas funções estão expressamente enumeradas no CPP. Cf. A prova...cit., p. 131.

${ }^{460}$ Idem, p. 132;

461 Para Cleunice A. Valentim Bastos Pitombo, no processo penal inexiste norma regradora do sigilo profissional. A normatização é feita quanto à prova testemunhal. Cf. Processo penal: prova e verdade. Tese de doutorado apresentada na Faculdade de Direito da Universidade de São Paulo. São Paulo, 2003, p. 153.

462 TARUFFO, Michele. La prueba. cit., p. 51.

${ }^{463}$ Esse o entendimento de Manuel da Costa Andrade: "Mais do que garantias processuais face à agressão e devassa das instâncias de perseguição penal, os direitos ou interesses que emprestam sentido axiológico e racionalidade teleológica às proibições de prova, emergem como direitos fundamentais erigidos em autênticos bens jurídicos. E, por isso, com referenciais e fundamentos autônomos duma tutela que transcende o horizonte do processo penal". Cf. Sobre as proibições de prova em processo penal. Coimbra: Coimbra Editora, 2006, p. 188.

${ }^{464}$ ANDRADE, Manuel da Costa. Sobre as proibições de prova...cit., p. 53.

${ }^{465}$ Idem, p. 53;
} 


\subsection{A escusa de depor: perspectiva processual}

Estabelecidos pelo regime processual, os segredos profissionais são proibições de prova $^{466}$, ou restrições ao direito à prova, e são previstos como derrogação do dever de depor como testemunha ${ }^{467}$.

A prestação de testemunho no processo é ato de caráter público, consistente em um dever diante do Estado, no interesse da Justiça na busca da verdade processual. ${ }^{468} \mathrm{Em}$ matéria penal, o testemunho ainda é uma das provas mais relevantes ${ }^{469}$ para a reconstrução e conhecimento dos fatos, embora seja muito criticada, porque o sujeito detentor do conhecimento sobre o objeto do processo é pessoa humana que sofre influências externas, consciente ou não, capaz de afetar a fidelidade do testemunho.

Não obstante, através da testemunha produz-se prova relevante para o processo penal. Por conseguinte, aquele que, de alguma maneira, conhece os fatos constitutivos do objeto do processo, ou sabe algo importante sobre eles, ${ }^{470}$ em sendo chamado para prestar depoimento, não pode deixar de fazê-lo. ${ }^{471} \mathrm{O}$ descumprimento dessa obrigação poderá

\footnotetext{
${ }^{466}$ A doutrina alemã distingue o conceito geral de proibições probatórias entre proibição de produção de provas, "que regulam ou limitam o modo de obtenção das provas", e proibições de utilizações das provas, que regulam ou limitam "o uso judicial das provas que já foram obtidas". Cf. AMBOS, ai. Las prohibicones de utilización de pruebas en el proceso penal alemán. In: ; Ernst Beling; Óscar Julián Guerrero. Las prohibiciones probatórias. Bogotá: Temis, 2009, pp. 64-65; Manuel da Costa Andrade discorre sobre a distinção entre proibição de produção de provas e proibição de valoração das provas, como distinções do termo mais amplo: proibições probatórias. Além disso, questiona a afirmação de BELING segundo a qual as proibições de produção de prova implicariam, necessariamente, proibições de valoração. Esclarece o doutrinador que "hoje aceita-se, generalizadamente a tese de um estatuto diferenciado da proibição de produção no que toca à sua projecção em matéria de proibição de valoração", defendendo a autonomia dos conceitos, tanto no âmbito normativo quanto no dogmático. Cf. Sobre proibições de prova... cit., pp. 59-60.

${ }_{467}$ art. 206 do CPP: “A testemunha não poderá eximir-se da obrigação de depor. (...)”.

${ }^{468}$ FLORIAN, Eugenio. Elementos de derecho procesal penal. Traducción de L. Prieto Castro. Barcelona: Bosch, 1934, p. 344.

${ }^{469}$ GORPHE, François. Apreciación judicia de las pruebas. Traducción de Luis Alcalá-Zamora y Castillo. Buenos Aires: Hammurabi, 2007, p. 303.

${ }^{470}$ José Frederico Marques define "prova testemunhal" como "a que se obtém com o depoimento oral sobre fatos que se contêm no litígio penal". Cf. Elementos de direito processual penal. vol. II, Rio de Janeiro: Forense, 1965, p. 335.

${ }^{471}$ Artigo 206 do CPP: “A testemunha não poderá eximir-se do dever de depor. (...)”. A testemunha não pode eximir-se do dever de prestar declarações sob o compromisso de dizer a verdade, sob pena de condução coercitiva (art. 218 do CPP).
} 
ensejar a condução coercitiva determinada pelo juiz, o que torna de caráter obrigatório, o dever de testemunhar. ${ }^{472}$

No entanto, o dever geral de testemunhar é derrogado, por lei, em razão de segredo profissional do depoente e, tão somente as pessoas vinculadas ao dever de sigilo têm esse "privilégio probatório" 473 .

Esse limite normativo da prova testemunhal surge da necessidade de equilíbrio entre a descoberta da verdade através da prova e a tutela de interesses públicos ou privados, constitucionalmente garantidos. A produção de prova, no caso, é proibida e, por consequência, alguns elementos que poderiam demonstrar a ocorrência dos fatos, não serão introduzidos no processo.

O art. 207 do Código de Processo Penal, porém, na sua parte final, traz disposição de regra de proporcionalidade que possibilita o limite à proibição probatória referente ao segredo. Assim, se o profissional qualificado estiver desobrigado pela parte interessada poderá, se quiser, dar o seu testemunho e revelar o sigilo. Trata-se de faculdade de prestar o depoimento, podendo não ser utilizada por razões de ordem deontológica, de credibilidade do profissional quanto à manutenção das informações conhecidas durante o exercício do trabalho e de discrição, imprescindível a determinadas profissões. Não obstante o direito à escusa de testemunhar possa prejudicar o cliente ${ }^{474}$, cabe ao profissional, nessa hipótese, a decisão de falar, ou não, em juízo.

\footnotetext{
${ }^{472}$ Cumpre ressaltar que, da obrigação de testemunhar surge o dever de dizer a verdade, ou seja, procurar ser fiel à sua percepção sobre o fato e expô-lo da maneira mais completa e correta. Existe, portanto, um verdadeiro direito à prova testemunhal. Se a testemunha tem o dever de comparecer em juízo e dizer a verdade, o legislador processual penal assegurou o direito às partes de obter o comparecimento das pessoas por elas arroladas, para que trouxessem elementos de confirmação ou exclusão dos fatos alegados, configurando, assim, a efetiva possibilidade de influenciar a decisão judicial.

${ }^{473}$ Em relação à proteção de segredos, Michele Taruffo diz que os sistemas processuais regulam "privilégios probatórios" para a proteção de diversos interesses. Ressalta, ainda, que "na Alemanha, os segredos não só se protegem permitindo a exclusão do testemunho, senão também prevendo audiências não públicas para interrogar as testemunhas. Este é um mecanismo interessante dirigido a proteger segredos sem prejudicar substancialmente a busca da verdade". Cf. La prueba...cit., p. 52.

${ }^{474}$ No ordenamento processual italiano, ao contrário do CPP brasileiro, "a vontade do titular do direito ao segredo é determinante: se ele consente com a revelação, não há dever de fidelidade que se possa dizer violado e, por isso mesmo, a revelação do segredo não pode diminuir a estima de que goza o profissional". Cf. AZZALI, Giampiero. Prove penali e segreti. Milano: Giuffrè, 1967, p. 42.
} 
A razão pela qual a norma não afasta a restrição da obtenção da prova, mesmo com o consentimento válido do interessado direto na manutenção do segredo, é a necessidade de tutelar a relação bilateral que existe, necessariamente, entre o profissional e o cliente, que possibilita revelação de segredos pessoais.

O segredo que justifica a proibição de prova não se restringe ao depoimento da testemunha, mas abarca aquele cujo conhecimento foi obtido por documentos. Embora o art. 207 do CPP fale em "depor", o profissional não pode ser obrigado a exibir documentos os quais contenham informações sigilosas de clientes. Tampouco é possível a busca e apreensão em locais em que a atividade profissional é exercida. Qualquer diligência, nesse sentido, é considerada ilegal e inconstitucional.

\subsection{O dever de comparecer em juízo}

Mister ressaltar que as pessoas que estejam nas condições previstas no art. 207 do CPP, não estão dispensadas de depor, mas tão somente de revelar fatos violadores do segredo que devem preservar. ${ }^{475}$

Comparecer em juízo é uma das obrigações da testemunha e os profissionais mencionados, quando arrolados para prestar depoimentos devem alegar o sigilo, cabendo ao juiz verificar a procedência, ou não, do fundamento da escusa de depor. A proibição do art. 207 do CPP, diz respeito à exceção da obrigação de responder, não aquela de apresentar-se em juízo, pois somente ouvindo a testemunha será possível aferir se se trata de situação de manter em sigilo os fatos, porque não devem ser conhecidos. ${ }^{476}$

\footnotetext{
${ }^{475}$ Walter Ceneviva defende, para os advogados, o direito de não comparecimento em juízo quando chamado a testemunhar. Cf. Segredos...cit., p. 146. No mesmo sentido, REGO, Hermenegildo de Souza. Dever de sigilo e escusa de depor. Revista de processo, ano IX. São Paulo: RT, janeiro-março de 1984, n. 33, p. 216; Segundo Paolo Tonini, "algumas testemunhas com determinadas qualidades específicas têm a faculdade (do ponto de vista do procedimento penal) de não responder a determinadas perguntas quando a resposta implicar violação do dever de segredo profissional". Cf. A prova...cit., p. 131.

${ }^{476}$ Segundo José Frederico Marques, "a pessoa arrolada como testemunha tem as obrigações seguintes: a) comparecer em juízo no local, dia e hora designados para o depoimento (art. 218); prestar depoimento (art. 206); c) dizer a verdade do que souber ou lhe for perguntado (art. 203)". Cf. Elementos...cit., p. 336;O art. 198, I do CPP italiano determina, entre as três obrigações fundamentais da testemunha, "a de apresentar-se perante o juiz". Somente com "idônea justificação" é possível subtrair-se a tal obrigação. Trata-se do princípio entendido como "universalidade da obrigação testemunhal" Cf. FADALTI, Luigi. La testimonianza nel giudizio penale. Milano: Giuffrè, 2008, p. 31.
} 
A dispensa, desde logo, da pessoa chamada a testemunhar, não atende ao princípio da busca da verdade processual, pois viola o direito à prova das partes ${ }^{477}$, que ficam privadas do conhecimento da razão da escusa e, por conseqüência, da prova. E, a motivação da recusa de depor, pelo profissional, deve ser apreciada pelo juiz, o qual decidirá sobre a procedência das razões expostas. O profissional proibido de depor em razão de segredo, portanto, deve comparecer e alegar o impedimento. ${ }^{478}$

Seria conveniente a instauração de incidente processual para verificar "se é legítima a recusa da parte de depor sobre certo fato". ${ }^{479}$ É o sistema adotado no Código de Processo Penal Português que trata a escusa de depor, em virtude de segredo profissional, como incidente processual de quebra de sigilo, com a participação obrigatória do organismo representativo da profissão relacionada com a causa. ${ }^{480}$

\subsection{A relatividade do segredo profissional}

Não se pode excluir, também, a hipótese de o profissional revelar o segredo, sem a anuência do interessado, ao decidir testemunhar ou entregar documentos com informações que não devem ser divulgadas. No caso, a obtenção da prova é ilícita e, como tal, não pode ser admitida, devendo ser desentranhada do processo porque violou norma legal e constitucional. ${ }^{481}$

\footnotetext{
${ }^{477}$ As partes têm direito de pedir a produção de prova e obter a prova solicitada, "nos limites entre os quais ela possa vir admitida, ou, obter uma tempestiva decisão - distinta da sentença final - sobre o pedido regularmente feito". Cf. GREVI, Vittorio. Prove. In:___ CONSO, Giovanni. Compendio di procedura penale. 2 ed. Milano: CEDAM, 2003, pp. 298-299; No mesmo sentido: MARZADURI, Enrico. Diritto Allá prova testimoniale e modalità di escussione del testimone. In: Verso uno statuto del testimone nel processo penale. Milano: Giuffrè, 2005, p. 19.

${ }^{478}$ Enfatiza João Bernardino Gonzaga que, "entre nós, se se convencer de que a invocação do dever de silêncio não passa de pretexto para acobertar erro do próprio profissional, o juiz recusará acolhê-la e exigirá que a testemunha deponha”. Cf. Violação...cit., p. 204.

${ }_{479}$ MOREIRA, José Carlos Barbosa. O novo processo civil brasileiro. $6^{\text {a }}$ ed. Rio de janeiro: Forense, 1984, p. 116.

${ }^{480}$ Art. 135, 1 a 5 do CPP Português.

${ }^{481}$ Nesse sentido, Eduardo Espínola Filho diz que "se deve riscar dos autos" o depoimento. Cf. ESP NOLA FILHO, Eduardo. Código de Processo Penal brasileiro anotado. $5^{\text {a }}$ ed. Rio de Janeiro: Editora Rio, 1976. vol. 3, p. 115; A Lei 11.690 2008, deu nova redação ao art. 157 do CPP, dizendo: "são inadmissíveis, devendo ser desentranhadas do processo, as provas ilícitas, assim entendidas as obtidas em violação a normas constitucionais ou legais"
} 
Todavia, ainda que o interessado não tenha consentido na divulgação, entendemos possível, em casos excepcionais, ponderar os interesses em conflito para autorizar a imposição de limite à proibição probatória. Os segredos profissionais regulados no art. 207 do CPP, tutelados por lei ordinária, não possuem estatura constitucional e devem ceder diante de outros valores mais relevantes.

Assim sendo, não é absoluto o direito de o profissional não depor, quando o titular do segredo autorizou a divulgação. De igual modo, se devidamente fundamentado, pode-se permitir o depoimento da testemunha qualificada, sem a anuência do interessado na manutenção do segredo. Em ambos os casos, aplicada a regra da proporcionalidade, o dever de sigilo poderá ser derrogado e a prova obtida pelo testemunho, considerada válida no processo. ${ }^{482}$

A revelação do segredo, nessas hipóteses, pode ser legítima para evitar um mal maior, como a condenação de um inocente no processo penal, ou a prática iminente de um crime grave. De qualquer maneira, os interesses em conflito devem merecer o devido equilíbrio pelo Poder Judiciário, respeitados os direitos e interesses individuais tutelados pela Constituição. $^{483}$

Aquele que divulgou um fato secreto, em condições especiais para um profissional, tem direito que permaneça ele sob sigilo. Logo, excepcionalmente, em hipóteses circunscritas à lei ou com determinação judicial, ponderados os valores que se contrapõem, poderá haver limite à proibição de prova. ${ }^{484} \mathrm{Em}$ cada situação concreta ${ }^{485}$, deve ser

482 É o entendimento de Adalberto José Q. T. de Camargo Aranha. Cf. Da prova no processo penal. São Paulo: Saraiva, 7 ed. rev. ampl., 2006, pp. 308-309. Para o Professor Antonio Magalhães Gomes Filho, no entanto, "os segredos tutelados por disposições de lei ordinária devem ceder diante do interesse à demonstração da inocência”. Cf. Direito à prova...cit., p. 130.

${ }^{483}$ Rodrigo Santiago diz que, modernamente se entende que o segredo profissional tem por base um verdadeiro conflitos de valores, resultante da proteção da privacidade e na liberdade de expressão, nas vertentes de receber e transmitir informações. Cf. Do crime de violação de segredo profissional no Código Penal de 1982. Coimbra: Almedina, 1992, pp. 102-103.

${ }^{484} \mathrm{Diz}$ alter Ceneviva que "nem sob a ótica do bem comum, mas até pelo respeito ao superior interesse que este representa, se pode dizer que o segredo profissional é absoluto. A doutrina tem destacado a relatividade, servindo-se de exemplos que a dramatizam: a manutenção do segredo para permitir que o inocente seja condenado; para que o cliente cumpra a promessa de que matará alguém; o silêncio médico dando ensejo ao portador de síndrome de imunodeficiência adquirida de se casar com pessoa sadia." Cf. Segredos profissionais. São Paulo: Malheiros, 1996, p. 29.

${ }^{485}$ Em situação de conflito, caberá ao juiz do processo criminal decidir pela prevalência de um dos valores: se a produção da prova ou a preservação do sigilo. Conforme J.J. Gomes Canotilho, "eventual relação de prevalência só em face das circunstâncias concretas se poderá determinar, pois só nestas condições é legítimo 
verificado se a revelação do sigilo, em situações não autorizadas, “é necessária, adequada e justificável em face do valor que se protege" ${ }^{\text {486 }}$.

O Código Penal adotou a tese de relatividade do segredo profissional ao consagrar no art. 154 a ressalva da “justa causa” que, presente na revelação do segredo, descaracteriza a conduta como crime. Certo, enfatiza Nelson Hungria, que nada há de menos absoluto do que o segredo profissional, pois todo dever encontra limite na função social, razão pela qual é "relativo per definitionem". 487

\subsection{As pessoas vinculadas ao dever de sigilo.}

Não basta ser um profissional de cujos serviços utilizamos e a quem acabamos por confiar algum segredo, para que esteja proibido de depor como testemunha. É imprescindível que o conhecimento de fatos secretos dos que a ele recorrem seja inerente à ocupação "por natureza ou por imposição legal" "488. São, portanto, os "confidentes necessários", pessoas que não podem prestar serviços relativos às suas profissões, funções, ministério ou ofício, sem que para o desempenho do trabalho tenham acesso a segredo de particulares. $^{489}$

Essa confidência necessária decorre de uma relação de confiança que o indivíduo tem, não apenas na pessoa do profissional, mas, sobretudo, na qualificação que o habilita a prestar-lhe o serviço que necessita, e na crença de que ele é obrigado a cumprir

dizer que um direito tem mais peso do que o outro, ou seja, um direito prefere outro em face das circunstâncias do caso". Cf. Direito constitucional. cit., p. 647.

486 SCARANCE FERNANDES, Antonio. Processo penal constitucional. 6 e. rev. ampl. atual. São Paulo: Revista dos Tribunais, 2010, p. 86.

487 HUNGRIA HOFFBAUER, Nelson. A violação do segredo profissional. Revista dos Tribunaes. Vol XCIX, n. 428, Anno XXV, janeiro de 1936, p. 299.

${ }^{488}$ GONZAGA, João Bernardino. Violação de segredo profissional. São Paulo: Max Limonad, 1976, p. 59.

489 Esclarece João Bernardino Gonzaga, que "não é preciso que certa confidência tenha sido efetivamente necessária, mas basta que se entrose logicamente com a matéria da consulta; ou seja, que exista um liame de causa e efeito entre o conteúdo do serviço prestado e o que, em razão dele, o paciente revela. Pode dar-se que este conte algo dispensável, que supõe erroneamente deva mencionar, ou que o faça apenas para tornar mais completa a exposição. Não se dirá, pois, necessária a confidência. Apesar disso, ficará o profisssional impedido de transmiti-la a terceiros. Assim, se no curso de uma entrevista médica o cliente explica que o seu depauperamento orgânico se origina de dificuldades financeiras que atravessa, é manifesto que esse último informe não carecia ser fornecido; mas também estará abrangido pelo dever de sigilo." Cf. Violação...cit., p. 60. 
determinados deveres e seguir normas éticas e deontológicas da profissão. ${ }^{490}$ A existência de um liame pessoal, individual, entre duas pessoas, é essencial para a noção de confidência, na qual repousa o segredo profissional. ${ }^{491}$

Portanto, são essas pessoas, vinculadas ao dever de sigilo, as que podem escusar-se de depor como testemunhas, sobre fato que implique em divulgação de segredo profissional. A lei lhes impõe o dever de calar. ${ }^{492}$

\subsubsection{Médicos e Advogados}

O exercício da profissão médica não pode prescindir da relação de confiança entre a pessoa com a função de curar e o paciente. Isso porque, a revelação de fatos da intimidade do paciente é característica do relacionamento profissional. A verdade sobre os sintomas, o modo de vida, por vezes até sobre as relações pessoais do paciente, são necessárias para o diagnóstico da doença, o que justifica o segredo médico. ${ }^{493}$ Logo, o médico tem o dever de guardar sigilo sobre as informações que obteve no desempenho de suas funções. ${ }^{494}$ Aliás, o dever de sigilo médico, desde Hipócrates, sempre foi respeitado ${ }^{495}$ e é princípio fundamental da profissão, conforme dispõe o Código de tica Médica: “ $O$ médico

\footnotetext{
${ }^{490}$ ALEIXO, Pedro. Segredo profissional. Revista Forense, Anno XXXIII, fasc. 391, Rio de Janeiro,1936, p. 451.

${ }^{491}$ WAREMBOURG-AUQUE, Francoise. Réflexions sur le secret professionnel. Revue de science criminelle et de droit pénal comparé. n. 2, Paris: Sirey, Avril-Juin, 1978, p. 240.

${ }^{492}$ No processo civil, entretanto, a lei lhes institui um direito ao silêncio, facultando ao depoente requerer ao juiz que se escuse de depor. Dispõe o art. 406 do Código de Processo Civil: "A testemunha não é obrigada a depor de fatos: (...)II - a cujo respeito, por estado ou profissão, deva guardar sigilo"; João Cláudio Couceiro esclarece que o art. 207 do CPP, impõe "não mais um direito ao silêncio, mas verdadeiro dever de silêncio". No mesmo sentido é o disposto no art. 355 do CPPM. Cf. A garantia constitucional do direito ao silêncio. São Paulo: Revista dos Tribunais, 2004, p. 237.

${ }^{493}$ Afirma Maria do Céu Rueff, que "o segredo médico é fundamental para o método médico e permite o próprio conhecimento médico". Cf. O segredo médico como garantia de não-discriminação. Estudo de Caso: HIV/SIDA. Coimbra: Coimbra Editora, 2009, p. 457.

${ }^{494}$ O dever de sigilo médico está previsto no Cap. I, XI do Código de Ética Médica, aprovado pela Resolução 1.931, de 17.09.2009, do Conselho Federal de Medicina (em vigor a partir de 13.04.2010). Cf. DOU 24.09.2009 - Poder Executivo, Seção I, p. 90-92.

${ }^{495}$ Extrai-se o sigilo médico como tradição, do juramento de Hipócrates (460 A.C.): "O que no exercício ou fora do exercício e no comércio da vida eu vir ou ouvir, que não seja necessário revelar, conservarei como segredo".
} 
guardará sigilo a respeito das informações que detenha conhecimento no desempenho de suas funções, com exceção dos casos previstos em lei,",496.

A preservação do sigilo, no entanto, não é absoluta. ${ }^{497} \mathrm{~A}$ própria lei a releva, como na hipótese prevista no art. 269 do CP, o qual tipifica como crime o ato de "deixar o médico de denunciar à autoridade pública doença cuja notificação é compulsória".

Sob o aspecto da prova penal, o depoimento do profissional da medicina pode ser ordenado, ou o prontuário médico ${ }^{498}$ do paciente, requisitado, quando houver causa imperiosa que justifique, ${ }^{499}$ no caso concreto, a prevalência da busca da verdade no processo. $\mathrm{O}$ momento e as condições da proteção da intimidade do paciente pelo sigilo serão avaliados, inicialmente pelo médico e, em seguida, o juiz decidirá, de maneira fundamentada se há “justa causa" ${ }^{, 500}$ para restringir o segredo profissional.

A confiança, também é requisito essencial nas relações entre o advogado e cliente. Os dramas da vida, as angústias pessoais são trazidos para dentro do escritório de advocacia e revelados a quem se confia; a vulnerabilidade de quem precisa de um profissional que o ampare na defesa de seus direitos, a exposição da intimidade e das

\footnotetext{
${ }^{496}$ Capítulo I, inciso I da Resolução CFM n. 1.931, de 17.09.2009; DOU, 25.09.2009, Seção 1 - Executivo, p. 90-92 (Em vigor desde 13.04.2010).

${ }^{497} \mathrm{Na}$ Argentina, surgiu polêmico caso conhecido como "Zambrana Daza". Norma Beatriz Zambrana Daza foi internada porque sentiu-se mal após ter ingerido 40 cápsulas de cocaína pura. A médica que a atendeu levou os fatos a conhecimento da polícia. Zambrana Daza foi condenada por tráfico de entorpecentes, mas teve seu processo anulado pela Câmara Federal, cujos juízes entenderam que as investigações foram iniciadas com violação de segredo profissional, portanto, as provas que sustentavam a condenação eram ilícitas. Posteriormente a Câmara Nacional de Apelação revogou a decisão de nulidade do processo e Zambrana Daza acabou condenada, pois entendeu-se haver um interesse público à verdade no processo penal e um dever de a médica denunciar fato criminoso de que teve conhecimento. Cf. Câmara Nacional de Apelaciones, Sala I, Causa n. 25.883, 14 de febrero de 1995. In: SUCAR, Germán; RODRÍGUEZ, Jorge L.; IGLESIAS, Agustín. Violacion de secretos y obligación de denunciar: un dilema fictício. Um comentário crítico al fallo "Zambrana Daza". Cuadernos de doctrina y jurisprudencia penal. n. 8, Buenos Aires: Ad-Hoc, s/d, p. 190296.

${ }^{498}$ Prontuário médico é um "conjunto de documentos médicos e correlatos referentes a um paciente", portanto, tem caráter sigiloso. Cf. COUTINHO, Léo Meyer. Código de ética médica comentado. 2. ed. São Paulo: Saraiva, 1994, p. 82.

${ }^{499}$ Nos termos do art. 73, Cap IX - Sigilo profissional - do Código de tica Médica: “ vedado ao médico (...) revelar fato que tenha conhecimento em virtude do exercício de sua profissão, salvo por motivo justo, dever legal ou consentimento, por escrito, do paciente".

${ }^{500}$ Não é fácil, mesmo nos casos concretos, definir a "justa causa" que legitima a violação do segredo profissional protegido. Trata-se de conceito vago - "causa"- que envolve "valor"- "justo"-, o que possibilita um amplo campo de interpretação judicial. Sobre o conceito de "justa causa", cf. MOURA, Maria Thereza Rocha de Assis. Justa causa para a ação penal. São Paulo: RT, 2001, p. 97.
} 
mazelas morais da vida do cliente, justificam a necessidade do privilégio do sigilo inerente a essa função.

Ao advogado impõe-se o dever de fidelidade a quem dele se socorre. E para assegurar esse dever, o Estatuto da Ordem dos Advogados do Brasil estabelece ser um direito do advogado recusar-se a depor como testemunha em processo no qual funcionou ou deva funcionar, ou sobre fato relacionado com pessoa de quem seja ou foi advogado, mesmo quando autorizado ou solicitado pelo constituinte, bem como sobre fato que constitua sigilo profissional. A Lei 8.906/94 prevê o sigilo profissional como um direito e dever do advogado, e dispõe que sua violação, sem justa causa, constitui infração disciplinar, passível de sanção de censura até exclusão e multa. ${ }^{501}$

Não existe a possibilidade de o advogado prestar testemunho sobre sigilo inviolável do cliente e, nem mesmo quando autorizado, não se pode impor tal obrigação, pois "rompe-se o indispensável equilíbrio da justiça e fica infringida a norma cogente, que impõe o efetivo exercício da defesa" ${ }^{502}$. Até mesmo depois da morte do cliente o advogado tem o dever jurídico e moral de respeitar o segredo que lhe fora confiado.

Mister ponderar, no entanto, que o sigilo do advogado não pode servir de escudo para extremismo. O profissional da advocacia precisa agir com responsabilidade perante o seu cliente, mas também perante o Estado quando impõe seu ius puniendi através da ação penal. Assim, o direito de sigilo só se legitima nas expressas restrições da lei ${ }^{503}$, porque também não se trata de um privilégio absoluto.

501 Também está previsto o sigilo profissional no Código de tica e Disciplina da OAB, de 1995 : “Art. 25. $\mathrm{O}$ sigilo profissional é inerente à profissão, impondo-se o seu respeito, salvo grave ameaça ao direito à vida, à honra, ou quando o advogado se veja afrontado pelo seu cliente e, em defesa própria, tenha que revelar segredo, porém sempre restrito ao interesse da causa."; "Art. 26. O advogado deve guardar sigilo, mesmo em depoimento judicial, sobre o que saiba em razão de seu ofício, cabendo-lhe recusar-se a depor como testemunha em processo no qual funcionou ou deve funcionar, ou sobre fato relacionado com pessoa de quem seja ou tenha sido advogado, mesmo que autorizado ou solicitado pelo constituinte"; "Art. 27. As confidências feitas ao advogado pelo cliente podem ser utilizadas nos limites da necessidade da defesa, desde que autorizado aquele pelo constituinte. Parágrafo único. Presumem-se confidenciais as comunicações epistolares entre advogado e cliente, as quais não podem ser reveladas a terceiros".

${ }^{502}$ GONZAGA, João Bernardino. Violação... cit., p. 89.

${ }^{503}$ Marco Antonio de Barros. Sigilo profissional. Reflexos da violação no âmbito das provas ilícitas. Justitia, São Paulo, v. 175, jul.-set., 1996. 
Verifica-se, pois, que tanto ao médico, quanto ao advogado, as pessoas, mediante um acordo tácito, preexistente, fazem confidências que devem ser mantidas em sigilo para a preservação de seus direitos à dignidade, à intimidade, à honra e à liberdade. ${ }^{504}$ Para esses profissionais há, portanto, um direito ao regular exercício das funções e um dever de não revelar, sem justa causa, o segredo que lhes foi confiado, sob pena de responder pelo crime tipificado no art. 154 do Código Penal.

\subsubsection{Ministros de cultos religiosos}

Incluídos entre aqueles que são proibidos de depor em razão de "ministério", os ministros de cultos religiosos ${ }^{505}$, todos os sacerdotes, ou seja, os padres da Igreja Católica, os rabinos da Comunidade Israelita, os pastores das Igrejas Protestantes entre outros, devem guardar segredo de confissão ou aquele conhecido no exercício da fé religiosa, de qualquer forma. $^{506}$

Para o Código de Direito Canônico, que rege a Igreja Católica ${ }^{507}$, o sigilo sacramental (sigillum confessionis, ou sigillum sacramentale vel confessionis) é inviolável, não podendo o confessor trair o penitente, por qualquer que seja a causa. ${ }^{508} \mathrm{~A}$ violação do segredo de confissão acarreta a excomunhão do confessor, latae sententiae, reservada à Sé Apostólica. ${ }^{509}$ Neste ponto, o Direito Canônico influenciou as legislações dos países cristãos, visando à garantia do sigilo do sacramento da confissão pelas normas "laicas".

\footnotetext{
${ }^{504}$ Sobre as responsabilidades coincidentes quanto à preservação do segredo confiado, tanto dos médicos quanto dos advogados, ver AZERRAD, Marcos E. Ética y secreto profesional del abogado. Ejercicio y función social de la abogacía. Buenos Aires: Cathedra Jurídica, 2007, p. 346 e sgts.

${ }^{505}$ FINOCCHIARO, Francesco. Diritto ecclesiastico. 10 ed., Bologna: Zanichelli, 2009, p. 408.

506 Importante que não se admita a escusa de prestar depoimento aos "representantes de religiões improvisadas e até mesmo exóticas, às vezes com insignificante número de seguidores". Cf. GONZAGA, João Bernardino. Violação...cit., p, 84. Na legislação italiana (art. 200, I, a do CPP), as religiões, cujos ministros são proibidos de depor, são aquelas que não contrastam com o ordenamento jurídico. Na doutrina, ver comentário de MORELLO, Michele. Il nuovo processo penale. Parte generale. Padova: CEDAM, 2000, p. 904; TONINI, Paolo. A prova...cit., p. 133; DOSI, Ettore. La tutela del segreto nella prova testimoniale del processo penale. La scuola positiva. Rivista di criminologia e diritto criminale. Milano: Giuffrè, $1968, \mathrm{p}$. 446.

${ }^{507}$ Este direito rege as matérias de ordem espiritual ou aquelas conexas, ou mistas. Nessas, por vezes, o código remete às leis civis, leigas, a solução dos conflitos. Cf. RÁO, Vicente. O direito e a vida dos direitos. São Paulo: Editora Resenha Universitária, 1976, v. I, t. I, p. 122-123.

${ }^{508}$ Sobre a importância e o valor do sigilo para o Direito Canônico, ver GRASSI, Carmelo. Sigillo...cit., p. 681.

${ }^{509}$ Cânones $983, \S 1^{\circ}$ e $1388, \S 1^{\circ}$ do Código de Direito Canônico, promulgado pela constituição apostólica Sacrae disciplinae leges Catholica Ecclesia, do Papa João Paulo II, em 25 de janeiro de 1983.
} 
A liberdade de professar a fé religiosa de qualquer forma, protegida pelo legislador no art. 207 do CPP, incluída entre as liberdades espirituais, compreende a liberdade de culto tutelada no art. $5^{\circ}$, VI da $\mathrm{CF}$, o que abrange a possibilidade de praticar os atos próprios da religião. ${ }^{510}$ É a prática religiosa, na sua plenitude, o que justifica a proibição de prova em análise, além, por certo, da necessidade de proteção dos bens personalíssimos do confidente.

Também no exercício do "ministério", há uma relação de confiança entre o confessor e o confidente, que deve ser preservada. Somente com a anuência deste último, é possível revelar o sigilo.

A questão sobre a relatividade do segredo em confissão, não é tranquila ${ }^{511}$. Beling entende que hoje, essa proibição de prova é relativa e vai depender da explicação do sacerdote quando for chamado a testemunhar, podendo o juiz, liberá-lo, ou não, de prestar o depoimento. ${ }^{512}$

${ }^{510}$ SILVA, José Afonso da. Curso de direito constitucional...cit., pp. 248-249.

511 João Arruda relata caso acontecido em 1860, na cidade de Bananal, interior de São Paulo, que ilustra a dificuldade em que se encontrou o vigário da Paróquia após ter conhecimento de fato gravíssimo, em segredo de confissão. Um escravo, para se vingar do senhor, lançara corpos de muares mortos por doença infecto contagiosa, na represa cuja água era utilizada pelos escravos, que dela bebiam e nela se banhavam. A água contaminou os escravos que acabaram dizimados. $\mathrm{O}$ autor dos fatos, arrependido, confessou ao padre Luiz. Ligado pelo segredo, diante de uma luta interna que o agitou, pois o escravo estaria sujeito a pena de morte, $o$ padre julgou que podia aconselhar o fazendeiro a proibir o uso da água a qual, provavelmente, poderia ser a causa da doença que se alastrava. Não podendo ter sossego diante da tragédia que em redor dele se desenvolvia, suicidou-se o culpado. O fazendeiro descobriu a origem da doença e o crime praticado pelo seu escravo. O padre Luiz, "não podia ele, sacerdote de Cristo, lançar ao pescoço do escravo o nó corredio do baraço". Cf. Segredo profissional. Revista dos Tribunaes., São Paulo, 1928, v. LXVI, fasc. 342, p. 7; Outros casos ilustram a divergência de entendimentos sobre o segredo em razão do ministério: Em 2001, o padre jesuíta Joseph Towle revelou junto ao Tribunal Federal de Recursos de Nova York o nome de um dos autores de um assassinato cometido em 1987, no bairro do Bronx. Durante esses anos, dois outros homens estiveram presos, condenados pelo crime. Mas só em 1997, quando o autor do homicídio faleceu - Jesus Fornes - o padre revelou o que sabia. Na França, o bispo da província de Bayeux está sendo processado por ter mantido segredo de confissão de outro padre, René Bissey, em que admitia ter molestado vários meninos. No julgamento de Bissey, o bispo Pierre Pican se recusou a dizer se tinha ou não conhecimento do comportamento anormal do padre, invocando o sigilo do confessionário. Foi processado por ser cúmplice do padre Bissey, nos crimes pelos quais foi ele acusado. Cf. Disponível em http://veja.abril.com.br/250701/p_096.html. Acesso em 26 out. 2011.

${ }_{512}$ Para Beling, "se um sacerdote tiver um conhecimento conseguido na confissão e se atrever a afirmar que não sabe nada, seria perjúrio e de nada o serviria invocar a construção da teologia católica, segundo a qual não é o confessor quem escuta o que se confessa, senão Deus mesmo". Cf. Las prohibiciones probatórias...cit, p. 26; Pierre Lambert cita decisão do Tribunal Belga (1988) - Bruxelas - que aceitou o segredo de confissão como absoluto e inviolável. Esclarece o autor, todavia, que a questão é controvertida na doutrina francesa. Cf. Secret professionel. cit., p. 246. 
No Código de Processo Penal português, somente é possível a análise formal da legitimidade da escusa do sacerdote. Todas as escusas legítimas são também justificadas, ou seja, não se admite a quebra do segredo religioso "segundo o princípio da prevalência do interesse preponderante" (art. 135, 3). ${ }^{513}$

No sistema processual penal brasileiro, o tratamento normativo dado ao sigilo religioso é o mesmo dos demais segredos profissionais. Verifica-se, no entanto, uma dificuldade de os sacerdotes católicos revelarem o segredo de confissão - pena de excomunhão -, mesmo que desobrigados pela parte interessada. A causa que justificaria o levantamento do que está mantido em sigilo, em hipótese nenhuma justificaria a inviolabilidade do segredo de confissão, determinada pelo Código Canônico. Assim, em princípio, o depositário da informação que não pode ser revelada, deverá mantê-la sobre segredo, uma vez que o vínculo da reserva dos fatos revelados, que surge entre confessor e confidente constitui uma obrigação religiosa do sacerdote que transcende o interesse de quem a ele confiou seu segredo. ${ }^{514}$

Parece-nos que o segredo de confissão, embora tutelado na mesma norma dos demais segredos profissionais, como proibição de prova, não pode ser analisado da mesma maneira, pois daqueles se distingue.

O que faz uma pessoa buscar um ministro de culto é a necessidade de revelar-lhe, de confessar-lhe um fato secreto, guardado no mais profundo de sua intimidade. E a segurança de uma discrição inviolável o move para encontrar o consolo moral da religião que professa. ${ }^{515}$ Assim, o objeto da relação bilateral entre o sacerdote e o penitente é o próprio segredo, é o fato que nunca foi dado a ninguém conhecer e que se pretende manter sob reserva, que se revela em confissão. Mais do que a necessidade da "absolvição divina", a pessoa, pela confissão, livra-se da culpa pelo cometimento do fato, transferindo ao padre

\footnotetext{
513 Segundo Paulo Pinto de Albuquerque, "se o tribunal entender necessário, pode ouvir a Igreja ou a comunidade religiosa a que pertence a pessoa que invoca o segredo religioso para apurar se ela é efetivamente membro da mesma. Se o tribunal concluir que o pedido de escusa do ministro de religião é legítimo, o incidente deve ser julgado findo e o tribunal superior não chega sequer a pronunciar-se sobre o mesmo. Não se verifica aqui, qualquer juízo sobre a justificação da escusa, mas apenas um juízo sobre a sua legitimidade". Cf. Comentário...cit., p. 363.

${ }^{514}$ Nesse sentido, decisão da Corte di Cassazione italiana, de 17 dicembre 1953, Sez. I - Pres. Gabrieli - Rel. Castaldi - P.M. Mattioli (concl. Parz. diff.) que entendeu irrelevante a dispensa do confidente, uma vez que tem o direito de abster-se de testemunhar.

${ }^{515}$ MITTERMAIER, Karl Joseph Anton. Tratado de la prueba... cit., p.282.
} 
o seu segredo. Por conseguinte, a revelação de um segredo a quem se confia é o motivo da relação existente entre os ministros de culto e os confidentes.

No caso do médico, do advogado, a relação entre profissional e cliente tem por objeto a prestação de um serviço - o tratamento da doença, a defesa de interesses pessoais em juízo - cuja realização é possibilitada pelo relato de fatos que devem ser mantidos em segredo. O segredo, nessas hipóteses, decorre da razão motivadora da relação profissional, mas não é a finalidade da sua existência.

As normas da Igreja Católica, embora não devam prevalecer sobre a legislação do Estado laico, no qual alguns valores e princípios são irrenunciáveis, devem ser respeitadas. A proibição de o sacerdote depor como testemunha deve harmonizar-se com o dever de calar-se como ministro religioso. ${ }^{516}$

É o próprio princípio da laicidade que emerge da Carta Magna brasileira, o legitimador dos sacramentos religiosos. Isso porque, a laicidade "implica não indiferença do Estado frente às religiões, mas garantia do Estado para a salvaguarda da liberdade de religião, em regime de pluralismo cultural" ${ }^{17}$.Assim, o desrespeito aos atos de fé dos cidadãos, com a determinação Estatal, através do Poder Judiciário, de um ministro de culto violar as regras não só da Igreja, mas da sua própria consciência, atenta contra os fundamentos da confissão e reveste-se de absoluta arbitrariedade.

Significa admitir, portanto, que a proibição de prova em razão do segredo em confissão, pela sua peculiaridade, em princípio, deve prevalecer. Também deve prevalecer a restrição de prova em razão do segredo que terceiros confiaram a ministros de outros cultos religiosos, pois perante a lei, todas as religiões são igualmente livres para praticar os atos de fé. ${ }^{518} \mathrm{E}$, o reconhecimento legislativo da particular situação dos ministros de culto

\footnotetext{
${ }^{516}$ FLORIAN, Eugenio. Elementos de derecho...cit., pp. 350-351.

517 Decisão da Corte Constitucional italiana, 203 de 1989. Citada em: FARALLI, Carla. Bioetica e confessione religiose: uma prospettiva laica. In: CAMASSA, Erminia; CASONATO, Carlo. Bioetica e confessioni religiose. Atti del Convegno tenuto presso la Facoltà di Giurisprudenza di Trento, Il 12 maggio 2006. Trento: Lavis, 2008, p. 114.

518 PISANI, Mario. Testimonianza e segreti. In: La testimonianza nel processo penale. Atti del Convegno. Milano: Giuffrè, 1974, p. 76.
} 
expressa "o respeito aos deveres próprios de uma religião admitida no Estado, até o ponto em que o exercício de tais deveres não exceda a esfera consentida pelo interesse geral". ${ }^{519}$

No entanto, em casos excepcionais, quando não houver outro modo de resolver a questão, com a anuência do titular do segredo e havendo "justa causa" para o levantamento do sigilo, poderia ser determinado o testemunho do sacerdote, após ouvir o representante da Igreja.

${ }^{519}$ FLORIAN, Eugenio. Elementos de derecho...cit., p. 351. 


\section{A RELAÇÃO DO SIGILO DA FONTE DE INFORMAÇÃO JORNALÍSTICA COM A PROVA PENAL}

Nossa abordagem no capítulo anterior, sobre pontos específicos dos segredos profissionais mais estudados pela doutrina, visou a servir de base doutrinária para o estudo do sigilo da fonte do jornalista na sua relação com a busca da verdade através da prova penal.

Por tratar-se de categoria específica e muito distinta dos demais segredos de profissão, verificaremos que as diferenças substanciais entre eles e a inclusão na Constituição Federal, tão somente da tutela do sigilo da fonte do jornalista, conduzirão a uma dinâmica própria do acertamento dos fatos no processo penal, no que concerne ao alcance de uma verdade processual.

Verificaremos, então, em que medida a necessidade de tutelar a reserva da fonte de informação poderá impor-se como limite probatório na busca da verdade.

\subsection{Jornalistas e demais profissionais: segredos distintos.}

A peculiaridade do sigilo do jornalista está, exatamente, na revelação das informações que lhe foram transmitidas pela fonte. Nesse aspecto, não é o profissional da comunicação de massa um confidente necessário, como é o médico, o advogado, o religioso. ${ }^{520}$ A função primordial do jornalista, de divulgar as informações que obtém, não é compatível com o segredo, com a reserva do que soube por pessoas ou documentos.

\footnotetext{
${ }^{520}$ No Parlamento Português, em janeiro de 2004, debateu-se o Projeto de lei n. 130/IX, apresentado em outubro de 2002 pelo Bloco de Esquerda. O documento acentuou a distinção dos segredos profissionais dos advogados, médicos e dos jornalistas. Enquanto os primeiros, no âmbito de suas atividades, deveriam manter sigilosas as informações obtidas, "o jornalista, pelo contrário, tem como principal função divulgar as informações que obtém, incidindo o seu dever de sigilo sobre a protecção de sua fonte, pois sem essa protecção não haveria informação e, consequentemente, estaria limitado o direito a informar e ser informado". Em razão dessa característica diferenciadora do sigilo jornalístico, o Projeto de lei propôs alteração do art. 135 do Código de Processo Penal, equiparando o sigilo das fontes jornalísticas ao segredo religioso, possibilitando a limitação do primeiro quando ele fosse "a única e última forma de prevenir, directamente, um crime". O Projeto, no entanto, acabou rejeitado. Cf. FREITAS, Helena de Sousa. Sigilo profissional em risco. Análise dos casos de Manso Preto e de outros jornalistas no banco dos réus. Coimbra: Minerva, 2006, p. 58.
} 
Guardar, manter em segredo fatos revelados a si, portanto, não é pressuposto, não integra o exercício da sua profissão, cujo objetivo é informar-se para informar.

Essa a diferença mais notável entre o segredo do jornalista e dos outros profissionais: no primeiro caso a notícia é destinada à publicação, enquanto no segundo, a notícia que é dada pelo cliente é destinada a ser protegida pelo sigilo. Entre jornalista e informante não existe uma relação de confiança ínsita à profissão, presumida, que possui uma contraprestação econômica para o cumprimento de um serviço técnico, como há para o exercício das demais profissões. ${ }^{521}$ A pessoa que dá ao jornalista determinada informação, assim o faz não para que seja mantida em segredo, mas com o objetivo de que chegue ao conhecimento do público.

Tampouco, existe esse segredo para proteger, prima facie, a intimidade ou privacidade daquele que forneceu a informação, pois as pessoas buscam os jornalistas - ou são procuradas por eles, na maioria das vezes ${ }^{522}$ - por vontade ou interesse próprios, mas não por necessidade, quando são compelidas a exporem fatos de uma esfera estritamente pessoal e reservada. Se esses direitos personalíssimos, de alguma maneira e em algum momento, são protegidos pelo sigilo do jornalista, não o são com os mesmos contornos caracterizadores da confidência dos demais profissionais, para os quais a revelação de fatos íntimos, privados, é imprescindível para o êxito do serviço que deverão prestar ao cliente.

Decorre da tutela da intimidade do cliente a necessidade de proteger a relação profissional e o desenvolvimento da profissão médica, da advocacia etc., bens jurídicos distintos da liberdade de imprensa. Esse direito constitucional é o bem jurídico tutelado pelo legislador que o instrumentalizou, para sua eficácia, com o sigilo da fonte, para servir à liberdade de informação. ${ }^{523}$

\footnotetext{
521 NUVOLONE, Pietro. Il segreto giornalistico. In: Segreti e prova penale. Atti del Convegno. Milano: Giuffrè, 1979, p. 102.

${ }^{522}$ Segundo Javier Pradera, “os jornalistas não se limitam a receber um segredo, mas o buscam. [...] não se limitam passivamente a receber os segredos, mas o perseguem. Nessa ruptura da passividade, os jornalistas se assemelhariam aos detetives ou aos policiais, obrigados por sua profissão às vezes a guardar o segredo e a buscar os segredos". Cf. La extra a pareja. Notas para um debate sobre la clausula de conciencia y el secreto profesional. In: La clausula de conciencia y el secreto profesional de los periodistas. Madrid: Centro de Estudios Constitucionales, 1994, p. 32.

${ }^{523}$ SANCHES, Inês Raposo. Os direitos fundamentais dos jornalistas no acesso às fontes de informação, ao sigilo profissional e à protecção da independência. Dimensões concretizadoras do direito à liberdade de imprensa. Relatório da parte escolar do curso de aperfeiçoamento conducente ao Mestrado em Ciências
} 
Se o sigilo profissional dos jornalistas encontra seu fundamento na "livre circulação da informação no sistema social" ${ }^{\text {"524 }}$, o segredo a ser preservado é o da fonte, da origem da informação, da identidade do informante, não do conteúdo, dos fatos, da própria informação revelada, como se dá com os demais segredos. ${ }^{525}$ Alguns detalhes do conteúdo do que foi informado, no entanto, podem merecer a tutela quando, através deles, chegue-se à fonte, ou até mesmo quando, a pedido do informante, não devam ser divulgados. Mas trata-se de exceção à regra da ampla liberdade de informar tudo quanto ao jornalista foi dado conhecer.

A especificidade do fundamento da proteção do sigilo da fonte, como veremos, vai gerar um tratamento jurídico diverso dos demais segredos profissionais, muito embora abrangido na generalidade do art. 207 do Código de Processo Penal.

\subsection{Quem são os destinatários do sigilo da fonte?}

A regra do art. $5^{\circ}$, XIV da Constituição Federal permite concluir que o sigilo da fonte é tutelado quando necessário ao exercício da profissão referente à informação pela mídia. O segredo que instrumentaliza a liberdade de informação é reconhecido aos jornalistas ${ }^{526}$, pessoas que se dedicam profissionalmente a recolher, editar e divulgar notícias através dos meios de comunicação. Trata-se de um segredo que se projeta em uma determinada profissão, o jornalismo. ${ }^{527}$

Jurídico-Políticas 2002/2003, apresentado na Faculdade de Direito da Universidade de Lisboa. Lisboa, setembro de 2003, p. 33.

${ }^{524}$ MACHADO, Jónatas E. M. Liberdade...cit., p. 582.

${ }^{525}$ Nesse sentido, ROIG, Rafael de Asís. Secreto profesional e informacion. Derechos y Libertades. Revista del Instituto Bartolome de las Casas, Madrid, Año I, n. 2, pp. 153-176. Octobre/Marzo 1994, p. 156; Com o mesmo entendimento, diz Javier Augusto de Luca: “... A informação que recebem os demais profissionais afeta a informação mesma, enquanto que no caso dos jornalistas, incide sobre o sujeito que a proporciona e não sobre o conteúdo que é justamente o destinado a difundir". Cf. El secreto de las fuentes periodísticas en el proceso penal. Buenos Aires: Ad-Hoc, 1999, p. 54.

${ }^{526}$ O Estatuto do Jornalista de Portugal (Lei n. 1 99) dá uma noção ampla de jornalista: "1. São considerados jornalistas aqueles que, como ocupação principal, permanente e remunerada, exercem funções de pesquisa, recolha, selecção e tratamento de factos, notícias ou opiniões, através de texto, imagem ou som, destinados a divulgação informativa pela imprensa, por agência noticiosa, pela rádio, pela televisão ou por outra forma de difusão".

${ }^{527}$ Segundo Celso Bastos e Samantha Meyer-Pflug, alguns magistrados divulgam na imprensa opiniões sobre diversos assuntos, sem que sejam identificados, alegando "sigilo da fonte" o que, na verdade, trata-se de "anonimato", proibido pela Constituição Federal no art. 5, inciso IV. Para os autores, a concessão do benefício do artigo $5^{\circ}$, inciso XIV da CF, pertence exclusivamente ao jornalista, em decorrência de sua atividade profissional. Afirmam, ainda, que “... a extensão do direito de livremente expressar o 
O jornalismo é termo polissêmico. Pode ser entendido como a profissão do jornalista, o conjunto das atividades e técnicas usadas para a difusão de informações, a categoria e o complexo dos jornalistas. ${ }^{528}$ A profissão jornalística, que é a atividade praticada por profissional que exercite de modo habitual e remunerado a redação, comentário, reportagem, divulgação de notícias etc. ${ }^{529}$, é a tutelada pelo sigilo constitucional.

Como a Carta Magna refere-se à profissão, o jornalista deveria ser ainda, a pessoa habilitada para a função, ou seja, com registro profissional obtido após o curso superior de Comunicação Social. ${ }^{530}$ Todavia, o Supremo Tribunal Federal ${ }^{531}$ entendeu que a Constituição de 88 não recepcionou o art. $4^{\circ}$, inciso V, do Decreto-Lei 972/69, o qual exige diploma de curso superior para o exercício da profissão do jornalista. ${ }^{532}$

$\mathrm{Na}$ decisão, também foi firmado o entendimento de que a exigência do diploma para a prática do jornalismo viola a ampla liberdade de imprensa. Para o Ministro Relator Gilmar Mendes, “O jornalismo é uma profissão diferenciada por sua estreita vinculação ao pleno exercício das liberdades de expressão e de informação. O jornalismo é a própria manifestação e difusão do pensamento e da informação de forma contínua, profissional e remunerada. Os jornalistas são aquelas pessoas que se dedicam profissionalmente ao

pensamento, apesar de garantido constitucionalmente, não é uniforme para todas as pessoas ... ". Cf. Entrevista dos magistrados: sigilo da fonte ou anonimato? Revista da Advocacia Geral da União Eletrônica. Ano II, n. 10, maio 2011. Disponível em http://www.agu.gov.br. Acesso em 10 de novembro de 2011; O autor Sandro de Nardi faz abordagem completa sobre o tema da manifestação de opiniões pelos magistrados, ressaltando o "dever de fidelidade" aos valores constitucionais, bem como os limites da liberdade que possuem eles de expressarem-se sobre diversos assuntos. Cf. La liberta di espressione dei magistrati. Napoli: Jovene Editore, 2008, pp. 56- 59 e 141-157.

${ }_{528}$ GORLERO, Maurizio Pedrazza. Giornalismo e Costituzione. Padova: CEDAM, 1988, pp. 3-4.

${ }^{529}$ Nos termos do art. $2^{\circ}$ do Decreto-Lei n. 972 69, que regula o exercício da profissão jornalística: " $A$ profissão de Jornalista compreende, privativamente, o exercício habitual e remunerado de qualquer das seguintes atividades: a) redação, condensação, titulação, interpretação [...]; b) comentário ou crônica, pelo rádio ou pela televisão; c) entrevista, inquérito ou reportagem, escrita ou falada; d) planejamento, organização, direção e eventual execução de serviços técnicos de Jornalismo, como os de arquivo, ilustração gráfica de matéria a ser divulgada; [...]".

530 COSATE, Tatiana Moraes. Liberdade de informação e sigilo da fonte. Disponível em http://jus2.uol.com.br/doutrina/texto.asp?id=12767, p. 28. Acesso em 23 set. 2010.

${ }^{531}$ Recurso Extraordinário 511.961 São Paulo, Tribunal Pleno, Ministro Relator Gilmar Mendes, 17.06.2009. Ementa: Jornalismo. Exigência de diploma de curso superior, registrado pelo Ministério da Educação, para o exercício da profissão de jornalista. Liberdades de profissão, de expressão e de informação. Constituição de 1988 (art. $5^{\circ}$, IX e XIII, e art. 220, caput e $\S 1^{\circ}$ ). Não recepção do art. $4^{\circ}$, inciso V, do Decreto-Lei $n .972$, de 1969.

532 Dispõe o art. $4^{\circ}$, inciso V, do referido diploma legal: “O exercício da profissão de jornalista requer prévio registro no órgão regional competente do Ministério do Trabalho, que se fará mediante a apresentação de: [...] V-diploma de curso superior de Jornalismo, oficial ou reconhecido, registrado no Ministério da educação e Cultura ou em credenciada, para as funções relacionadas de 'a' a 'g' no art. $6^{\circ}$,". 
exercício pleno da liberdade de expressão. O jornalismo e a liberdade de expressão, portanto, são atividades que estão imbricadas por sua própria natureza e não podem ser pensadas e tratadas de forma separada. (...). A exigência de diploma de curso superior para a prática do jornalismo - o qual, em sua essência, é o desenvolvimento profissional das liberdades de expressão e informação - não está autorizada pela ordem constitucional, pois constitui uma restrição, um impedimento, uma verdadeira supressão do pleno, incondicionado e efetivo exercício da liberdade jornalística, expressamente proibido pelo art. 220, $\S 1^{\circ}$ da Constituição. ${ }^{533}$

O enquadramento da profissão jornalística tem sua base normativa no Decreto-Lei 972/69, com nova regulamentação dada pelo Decreto 83.284/79, em decorrência das alterações introduzidas pela Lei $6212 / 78^{534}$. Os textos normativos exigiram o diploma de curso superior de jornalismo para o exercício de algumas funções específicas ${ }^{535}$, até que essa exigência foi afastada pelo Supremo Tribunal Federal, por vício de inconstitucionalidade.

\subsection{O jornalista como testemunha no processo penal}

Disciplina o Código de Processo Penal, como regra geral da prova testemunhal, que "toda pessoa poderá ser testemunha" (art. 202), isto é, poderá "dar fé da veracidade de um fato" ${ }^{\natural 36}$, o que equivale ao sentido da palavra testemunha, derivada de testibus ou testando. $^{537}$

O jornalista é pessoa que poderá ter assistido ao fato objeto da prova no processo penal, ou que dele teve conhecimento e seu depoimento, como testemunha, terá relevância

\footnotetext{
${ }^{533}$ Recurso Extraordinário 511.961/SP, cit., p. 693.

${ }_{534}^{53}$ A Lei 6212/78 alterou dispositivo do decreto 972/69, que dispõe sobre a profissão de jornalista.

${ }^{535} \mathrm{O}$ diploma de curso superior de Jornalismo é exigido, para as funções relacionadas no art. 6 , "a" a "g": redator, noticiarista, repórter, repórter de setor, arquivista-pesquisador e revisor. Mister anotar, no entanto, que há Proposta de Emenda à Constituição n. 386/2009,feita por Paulo Pimenta do PT - Rio Grande do Sul, encaminhada ao Plenário da Câmara dos Deputados em 25 de outubro de 2011, que visa a alterar o $\S 1^{\circ}$ do art. 220 da CF de 88 .

${ }_{536}^{53}$ TOURINHO FILHO, Fernando da Costa. Processo Penal. , 25 ed., São Paulo: Saraiva, 2003, v. 3, p. 296.

${ }^{537}$ Testemunha, segundo Germano Marques da Silva, com origem nas palavras "antesto, antisto", é "a pessoa que se coloca directamente em face do objeto e conserva a sua imagem, como mero espectador". Curso de processo...vol. II, cit. p. 135.
} 
na busca da verdade processual. Chamado a depor, tem ele o dever jurídico ${ }^{538}$ de fazê-lo, "sob palavra de honra, a promessa de dizer a verdade (...)"? 539 Tem ele o dever de colaborar na busca da verdade no processo penal, ou poderá recusar-se, acobertado pelo sigilo profissional?

Não só os segredos profissionais são distintos, mas também a relação destes com a prova penal. $\mathrm{O}$ aspecto processual do segredo do jornalista não pode ser analisado como categoria similar aos demais segredos, como limites do direito à prova. Finalmente, na medida em que a lei processual não consagra mecanismos tendentes a remover o obstáculo da esfera do segredo de profissão jornalística, que acaba por interferir no ius puniendi estatal, caberá verificarmos se o sigilo da fonte é algo a ser superado, ou não, em nome da plena realização da justiça penal.

\subsection{O segredo do jornalista é segredo profissional para fins do art. 207 do CPP?}

Expostas as diferenças entre o segredo do jornalista e dos demais profissionais ${ }^{540}$, sobretudo em razão de o primeiro ter um verdadeiro direito, ou faculdade de revelar ou não a fonte de informação, enquanto aos segundos é imposto o dever de calar sobre fatos que tiveram conhecimento no exercício da profissão, Rodrigo Santiago chega a negar ao sigilo jornalístico a qualidade de "profissional". ${ }^{541}$ Mas não é o único fundamento. Entende o autor que como não se pode falar de "confidência" na relação entre jornalista e informante, porque o fato revelado é destinado à publicação, seria incorreta a referência a um segredo "profissional" do jornalista, mais acertado entender-se "segredo jornalístico, tout court, no sentido de proteção das fontes de informação." 542

\footnotetext{
538 Luigi Comoglio fala em um dever público de testemunhar, só limitado em hipóteses taxativas de abstenção. Cf. Le prove civili. cit., p. 576.

539 Artigos 206 e 203 do CPP, respectivamente.

${ }^{540}$ Cap. V, item 1.

${ }^{541}$ Cf. Jornalistas e "segredo profissional". Sub Judice. Justiça e sociedade. nº 15/16, jun./dez. 1999, p. 147.

542 SANTIAGO, Rodrigo. Jornalistas...cit., p. 148; É o entendimento, também de DERIEUX, Emmanuel. Droit des médias...cit., p. 417.
} 
O segredo da fonte, a nosso ver, é segredo profissional do jornalista, é uma "modalidade do segredo profissional",543. Porque esse não pode ser considerado "confidente necessário" 544 , quando chamado a testemunhar, o âmbito de proteção da confidencialidade da origem informativa não é o mesmo dos outros segredos profissionais, tutelados pelo art. 207 do Código de Processo Penal.

O legislador processual penal proibiu o depoimento das pessoas que em razão da profissão devam guardar segredo. Ora, o jornalista é depositário de uma informação e não de um segredo que deve ser mantido sob reserva. Não deve ele guardar, sob sigilo, a informação recebida, mas deve divulgá-la, publicar os fatos de que teve conhecimento em razão do exercício do seu direito de informar, pois essa é a sua função. ${ }^{545} \mathrm{O}$ segredo que pode ser mantido por este profissional é, tão somente, o da origem da informação que obteve, é o da fonte da notícia divulgada, da identidade do informante, cuja tutela é constitucional. $^{546}$

A regra do art. 207 do CPP não se aplica aos jornalistas. Não se trata de uma tutela formal, de um regime processual próprio relacionado ao segredo desses profissionais. A ratio da limitação legislativa, prevista nessa norma processual penal, do princípio da realização da justiça penal e da perseguição dos autores de delito, é impedir a difusão pública de algo que deve permanecer sob reserva, para assegurar valores e princípios invioláveis da pessoa humana.

E seria paradoxal a proibição de esclarecimentos, em juízo, de fatos que já atingiram dimensão pública. Daí que o jornalista, como testemunha, ao transpor a "versão dos fatos para os fatos" $" 547$, a narrativa própria da linguagem midiática para a linguagem

543 HUNGRIA, Nelson. A disciplina jurídica da liberdade de pensamento e informação. Revista dos Tribunais. Edição histórica. São Paulo: RT, dez. 2009, p. 464.

544 Segundo Diego Fajardo Maranha Leão de Souza, essa especial condição, peculiaridade do sigilo jornalístico faz com que a doutrina estrangeira recomende que seu estudo seja realizado "em uma categoria à parte da regra geral de sigilo profissional". Cf. Sigilo profissional e prova penal. Revista Brasileira de Ciências Criminais, n. 73, São Paulo: Revista dos Tribunais, julho-agosto de 2008, p. 115.

${ }^{545}$ TORRES, Mário Araújo. Algumas considerações sobre a liberdade de informação e segredo profissional dos jornalistas. Revista do Ministério Público. Ano 3, n. 12, Lisboa:Minerva, 1982, p. 159.

${ }^{546}$ Para Luigi Fadalti, trata-se da tutela "objetiva" do segredo, que diz respeito, tão somente, "aos nomes das pessoas que informaram o profissional da notícia, não os fatos dos quais veio o conhecimento". Cf. $L a$ testimonianza...cit., p. 94.

${ }^{547}$ A versão do fato divulgado pelo jornalista, mesmo que a ele corresponda de maneira fiel, contém dados direcionados à forma de notícia, é produto da transformação do fato, adaptado à linguagem da imprensa. 
própria do depoimento, poderá trazer elementos de prova relevantes à busca da verdade no processo penal.

A não revelação da fonte da notícia é, portanto, direito que poderá ser invocado em juízo sob a tutela da regra prevista no art. $5^{\circ}$, XIV da CF. Não se trata de uma norma destinada ao processo penal, ${ }^{548}$ mas que nele pode ser utilizada pelo seu destinatário para se escusar, no depoimento e durante ele, de revelar a origem de sua informação.

Até 30 de abril de 2009, quando o Supremo Tribunal Federal julgou a Arguição de Descumprimento de Preceito Fundamental (ADPF) $130^{549}$, concluindo que a Lei de Imprensa, n. 5250/67, foi integralmente revogada pela atual Constituição, havia a tutela infraconstitucional do sigilo da fonte. ${ }^{550}$ A Lei de Imprensa, inovadora neste aspecto, no art. $7^{\circ}$ assegurou "o sigilo quanto às fontes de origem de informações recebidas ou recolhidas por jornalistas, rádio-repórteres ou comentaristas". Mas a referida norma revogada -, embora pudesse ser invocada pelo jornalista como fundamento da sua escusa de depor, também não foi destinada a regular a prova penal.

A tutela formal do sigilo do jornalista, por conseguinte, substancia-se, adquire vida própria fora e anteriormente ao procedimento penal, e sua finalidade não é proibir que ele preste depoimento como testemunha em juízo, ou revele os documentos e materiais utilizados para elaborar a notícia publicada, mas possibilitar que ele proteja suas fontes para exercer, na plenitude, seu direito de informação. ${ }^{551}$

(Sobre o assunto, ver MARCONDES FILHO, Ciro. Comunicação e jornalismo: a saga dos cães perdidos. São Paulo: Haker, 2000, p. 86). Portanto, o depoimento do profissional poderá esclarecer pontos relevantes para fins de prova no processo penal. Daí a razão pela qual entendemos que o "jornalista testemunha”, em juízo, deverá transpor a versão do fato para o fato. $\mathrm{O}$ fato, e não a versão dele, poderá servir como elemento de prova penal.

${ }^{548}$ Esclarece Jaques de Camargo Penteado que "as normas sobre a prova, via de regra, estão nos Códigos de Processo [...]. Todavia, na área extrapenal, estatutos destinados à sistematização do direito material também regulam as provas, o que evidencia a complexidade do tema." Cf. A natureza das normas sobre as provas criminais. Revista dos Tribunais, ano 93, vol. 819, São Paulo: RT. Janeiro de 2004, p. 402.

${ }^{549}$ Sobre os reflexos do julgamento pelo Supremo Tribunal Federal, da ADPF n. 130, ver NUNES JÚNIOR, Vidal Serrano. Direito e Jornalismo. São Paulo: Verbatim, 2011, pp. 139-155.

${ }^{550}$ O Projeto de Lei de Imprensa, de autoria do Senador Mauro Benevides, de n. 3.232-A, de 20.09.1992, contempla o sigilo da fonte no seu artigo 10, parágrafos 4 e 5 : "Parágrafo $4^{\circ}$ - Nenhum autor de escrito ou notícia, ou veículo de comunicação social, poderá ser compelido a indicar o nome de seu informante ou a fonte de suas informações, não podendo seu silêncio, na ação penal, ser usado contra ele como presunção de culpa ou agravante"; Parágrafo $5^{\circ}$ - O sigilo da fonte não exclui as responsabilidades civis e penais, nem o onus da prova".

${ }^{551}$ Nesse sentido, LORETI, Damián: El derecho a la información. Buenos Aires: Paidós, 1995, p. 76. 


\subsection{Um método de aquisição do testemunho}

$\mathrm{Na}$ qualidade de testemunha, o jornalista tem o dever legal de comparecer para prestar depoimento, identificar-se e "dizer a verdade do que souber ou lhe for perguntado" (art. 203 do CPP).

É preciso que ele seja identificado para que o juiz possa verificar trata-se de uma testemunha qualificada, o que legitimará eventual escusa de revelar a fonte de sua informação.

Quanto à necessidade de prestar compromisso, no sistema jurídico brasileiro não se caracteriza como ato essencial. Possui caráter moral o empenho da honra em dizer a verdade. $^{552}$

Além disso, as declarações do profissional da mídia devem ser completas, coerentes com a informação que divulgou. Mas não é só. A verdade do depoimento, in casu, vai mais além. Todas as circunstâncias do fato, que não serviram quando da edição da notícia, deverão integrar o teor do depoimento.

O que se pretende na colheita do depoimento do autor da notícia é a credibilidade do que foi publicado, visando a que informações falsas ou fabricadas possam servir de prova. Na Espanha, chega-se a exigir que o jornalista, como testemunha, prove que a informação é verdadeira, pois a Constituição, no art. 20, item 1,d, protege, apenas, o direito de comunicar e receber, por qualquer meio de difusão, a informação que seja veraz. Logo, na doutrina espanhola, o segredo profissional do jornalista não é eficaz e deve ceder quando conste, suficientemente, que a fonte forneceu, dolosamente, informação falsa. ${ }^{553}$

Quanto ao método de inclusão da prova testemunhal no procedimento penal, a nova sistemática instituída pela Lei 11.689/2008, quanto ao exame direto e cruzado na

\footnotetext{
${ }^{552}$ Com ou sem o compromisso de dizer a verdade, o cometimento de crime de falso testemunho não fica afastado. Nesse sentido: FRAGOSO, Heleno Cláudio. Lições de direito penal - Parte especial. 4. Ed. Rio de Janeiro: Forense, 1984. vol. 2, p. 513; TORNAGHI, Hélio. Instituições de direito processual penal. São Paulo: Saraiva, 1978. v. 4, p. 90-91.

${ }_{553}$ OTERO GONZÁLEZ, María del Pilar. El secreto de las fuentes del periodista. Justicia y secreto profesional. Madrid: Universidad Carlos III, 2001, p. 175. Disponível em www.vlex.com/doctrina/Justicia_secreto_profesional/2300-407,030.html. Acesso em 14 nov. 2011.
} 
inquirição das testemunhas, aquela feita diretamente pelas partes, ${ }^{554}$ exigirá do juiz especial atenção na postura de cada uma dessas, cabendo indeferir perguntas feitas ao jornalista, cujo intuito seja induzi-lo a fornecer dados para posterior identificação da fonte de informação.

Não obstante seja legítima, per essentiam, a escusa de revelar a origem da notícia e de fornecer informações que permitam, indiretamente, a descoberta da identidade da fonte ${ }^{555}$ nessa última hipótese o jornalista deverá justificar a negativa, não podendo, simplesmente, recusar-se a falar. A ausência de justificativa configura cerceamento do direito à prova, pois a parte que será privada de um elemento probatório, o qual entende necessário para confirmar sua versão sobre os fatos, tem o direito de saber que a informação pretendida facilitará a revelação da fonte que, no entanto, o jornalista optou por mantê-la secreta. Significa dizer que, fatos ou dados que levem à origem da fonte também podem ser mantidos sob reserva, no entanto, deve o jornalista esclarecer que, se responder ao que lhe foi perguntado, poderá favorecer a revelação da fonte, cujo anonimato quer preservar.

O mesmo não se exige, por óbvio, quando ao profissional se pergunta, diretamente, a identidade da fonte. Se o jornalista utilizar de seu direito ao sigilo, basta invocá-lo, sem precisar justificar a recusa.

O diálogo entre aqueles que participam do ato processual, como expressão da observância do contraditório, não se efetiva na amplitude exigida pela nova disciplina da prova trazida pela Lei 11.690/2008, se a faculdade de o profissional não responder ao que

\footnotetext{
554 Nos termos do art. 212 do CPP, alterado pela Lei 11.690 2008, “As perguntas serão formuladas pelas partes diretamente à testemunha, não admitindo o juiz aquelas que puderem induzir a resposta, não tiverem relação com a causa ou importarem na repetição de outra já respondida. Parágrafo único. Sobre os pontos não esclarecidos, o juiz poderá complementar a inquirição." No exame cruzado, diz Antonio Magalhães Gomes Filho, “com suas perguntas, a parte contrária (cross-examiner) pode empregar táticas destinadas a extrair informações que a testemunha esteja relutante em fornecer, a evidenciar contradições no depoimento, a colocar em dúvida sua credibilidade etc., procurando, enfim, diminuir o valor das informações que a outra parte pretendeu obter com a inquirição direta. Embora esse método esteja sujeito a severas críticas, que enfatizam sua abusiva utilização como meio de confundir, humilhar e destruir as testemunhas do adversário, mistificando a verdade, ainda assim representa a mais importante garantia probatória no sistema adversarial." Cf. Provas. Lei 11.690, de 09.06.2008. In: MOURA, Maria Thereza Rocha de Assis. (Coord). As reformas no processo penal. As novas Leis de 2008 e os Projetos de Reforma. São Paulo: Revista dos Tribunais, 2008, p. 286.

${ }_{555}$ MARTINS, João Zenha. O segredo jornalístico, a protecção das fontes de informação e o incidente de quebra de escusa de depoimento. Revista do Ministério Público. Ano 27, n. 106, Lisboa: Minerva, Abr-Jun 2006, p. 104/83-137.
} 
lhe foi perguntado - tão somente na hipótese de informações que, indiretamente, identifiquem a fonte - prescindir de justificativa. Na hipótese em análise, entendemos que a necessidade de justificativa para não dizer é condição para a não existência da prova, para o limite legal ao direito de prova.

\subsection{A necessidade do sigilo para o exercício profissional}

Jornalismo verdadeiro só existe onde há preservação da identidade da fonte. A qualidade da notícia que vem a público, como regra geral, pressupõe a citação da origem da informação. ${ }^{556}$ Embora verdadeiras, as afirmações não são excludentes. Citar o nome do informante deve ser princípio norteador da conduta profissional do jornalista, não aplicável somente quando houver "necessidade clara e premente de manter sigilo", daí "as fontes de informação devem ser identificadas" $" 557$.

Naturalmente, a prioridade deve ser pela identificação das fontes, ${ }^{558}$ para maior credibilidade da notícia. Em determinadas situações isso é impossível, sobretudo no jornalismo investigativo que, pela sua própria natureza é dependente delas, que preferem manter-se no anonimato. Assim, se o jornalista ou a empresa para o qual trabalha, considera relevante a informação e de interesse público, e verificado que a revelação da fonte poderá gerar consequências a ela, a confidencialidade da origem da notícia está justificada.

\footnotetext{
556 Benedito Luiz Franco, no seu trabalho, também fez afirmação no mesmo sentido. Cf. Proteção constitucional...cit., p. 158; Sobre as vantagens e desvantagens do sigilo das fontes de informação, ver SANCHES, Inês Raposo. Os direitos fundamentais dos jornalistas...cit., pp. 50-51.

${ }^{557}$ Artigo VI da Declaração de Principios da American Society of Newspaper Editors (ASNE), adotada em 1922 como os Cânones do Jornalismo. Posteriormente, revisado, em 1975 o documento transformou-se na Declaração de Princípios. Cf. BUCCI, Eugênio. Sobre ética...cit., p. 222.

${ }^{558}$ O Manual da Redação da Folha de São Paulo, São Paulo: Publifolha. 2001. em "verbete" próprio, é bastante específico quanto à "identificação de pessoa". Diz: "Na Folha, todo personagem de notícia deve ser identificado por profissão, cargo, função ou condição. Qualificações passadas (ex-presidente, ex-prefeito) só devem ser utilizadas quando relevantes no contexto. Ao identificar o personagem, procure ser específico. Informe a especialidade do médico, advogado, engenheiro, a faculdade ou escola onde o professor leciona, sua disciplina e, se for relevante, a escola em que o profissional se formou". Cf. na página 73.
} 
Questão atual e preocupante é relativa às notícias sobre crimes que envolvem corrupção nos Poderes do Estado, nas quais as fontes de informação ou são indiretas ${ }^{559}$ ou nem sempre apresentam clareza nas reais intenções da exposição midiática de determinadas pessoas que exercem funções públicas. ${ }^{560}$

As "fontes secretas", "irreveláveis", utilizadas indiscriminadamente, podem levar a notícias forjadas e à falsa ideia de que a justiça está sendo realizada. O problema, inicialmente, encontra-se no plano da infração de regras deontológicas ${ }^{561}$, de "irrecusável eficácia interna", que exige diligência e responsabilidade quanto ao que se noticia. ${ }^{562}$ No entanto, se ultrapassa o limite da informação pública e interfere na instrução probatória penal, os fatos decorrentes de "fontes fantasmas" deverão ser analisados sob a ótica da validade, ou não, como prova para o convenciomento do juiz no processo penal.

De qualquer maneira, o critério para avaliação da necessidade de "não revelação" da fonte é do profissional e/ou do meio de comunicação, os quais, no entanto, não se eximem da responsabilidade civil e criminal por danos que a publicação venha a causar a terceiros, pois devem assumir como próprias, as notícias divulgadas e as conseqüências do teor da publicação, quando decidirem manter sob reserva a identidade do informante.

\footnotetext{
559 aquela fonte sobre a qual "indiretamente o jornalista se baseia na descrição de um fato. Na maior parte dos casos o liame é estabelecido com dados precedentemente publicados em outro jornal ou periódico. [...] a nova publicação representará plena fonte de responsabilidade". Cf. ZENO-ZENCOVICH, Vicenzo; CLEMENTE, Michele; LODATO, Maria Gabriella. La responsabilità professionale del giornalista e dell 'editore. Padova: CEDAM, 1995, p. 253.

${ }^{560}$ Matthew Kieran, ao expor sobre os riscos do anonimato e da confidencialidade, diz que "as fontes podem confidenciar informações a fim de cumprir sua própria agenda. Por exemplo, tanto no Reino Unido quanto nos Estados Unidos, os jornalistas de política trabalham cada vez mais com o que se tornou conhecido com a arte do spin doctor [...] : um relações-públicas que tenta reverter uma publicidade negativa divulgando uma interpretação favorável de palavras ou atos de uma campanha ou ações de um partido político ou de uma figura pública". Cf. Estrutura ética e regulatória...cit., p. 188.

561 "Deontologia é a ciência que estabelece normas diretoras da atividade profissional sob o signo da retidão moral ou da honestidade, sendo o bem a fazer e o mal a evitar no exercício da profissão, o objeto da Deontologia profissional". Cf. ÁVILA, Fernando Bastos de. Pequena Enciclopédia de Moral e Civismo. Rio de Janeiro: Ministério da Educação e Cultura, 1967, p. 145; Para Joaquim Fidalgo, "a relação entre os jornalistas e as fontes de informação é, consabidamente, uma das facetas do trabalho jornalístico mais sensíveis a questões do domínio ético ... " E, portanto há a necessidade de sistematização das regras e princípios deontológicos que orientem, no plano da ética, a conduta desses profissionais. Cf. A questão das fontes nos códigos deontológicos dos jornalistas. In:Revista Comunicação e Sociedade, n. 2, vol. 14 (1-2), 2000, pp.319-320. Disponível e http://repositorium.\&dum.uminho.pt/bitstuam/1822/5511/1/CS_vol2_p.339_ 349.pdf. Acesso em 15/05/2010.

${ }^{562}$ MARTINS, João Zenha. O segredo jornalístico...cit., pp. 94-95.
} 


\subsection{O consentimento da fonte de informação}

Como direito de não revelar a fonte, quando entender necessário ao trabalho, o profissional da comunicação não pode ser obrigado, em juízo, a dizer o nome daquele através do qual teve conhecimento dos fatos, mesmo que a informação não tenha sido transmitida off the record (ou in off) ${ }^{563}$.

A fonte pode autorizar ou impedir sua identificação. O jornalista deverá manter o princípio da identidade do informante, como mencionado no item anterior, porém, impedido por aquela, deverá respeitar o compromisso assumido da confidencialidade, condição para que a informação lhe fosse prestada.

Se a fonte não solicita que os fatos sejam divulgados in off, ou até autoriza que seu nome venha a público, ainda assim o direito do jornalista não pode ser violado, pois eventual exigência nesse sentido, além de ferir sua consciência, é ilegítima, uma vez que não há no ordenamento jurídico meio de compeli-lo a falar, assim como não existe norma de onde se extraia que a garantia do sigilo para fins de trabalho, também seja um dever.

Por que não se trata de fatos que possam levar à descoberta do informante ${ }^{564}$, mas sim de identificação da fonte, a qual consentiu em ser revelada, também é ilegítima a exigência para que o jornalista, como testemunha, justifique a razão de manter seu informante no anonimato. O juiz, assim agindo, estaria impondo condição ao direito do profissional da mídia, além daquela fixada pelo legislador constituinte.

O consentimento da fonte na sua identificação não faz desaparecer a razão do sigilo, a razão de ser do interesse tutelado prima facie, o direito independente e autônomo do titular do segredo. Isso porque, insistimos, esse segredo também não é de exclusividade do jornalista, mas pertence à própria sociedade na medida em que instrumentaliza o mais

\footnotetext{
${ }^{563}$ A expressão, “em inglês, fora dos registros. Designa informação de fonte que se mantém anônima. (...) 1) Off simples - Obtido pelo jornalista e não cruzado com outras fontes independentes (...). 2) Off checado Informação off cruzada com o outro lado ou com pelo menos duas outras fontes independentes. (...) 3) Off total - Informação que, a pedido da fonte, não deve ser publicada de modo algum, mesmo que se mantenha o anonimato de quem fornece a informação. O off total serve só para nortear o trabalho jornalístico." Cf. Manual da Redação da Folha de São Paulo. Cit., p. 46.

${ }^{564}$ Vide item 3.2.
} 
amplo direito de informação que possibilita sejam os cidadãos esclarecidos e participativos.

\subsection{Limite ao dever de testemunhar. $O$ princípio do nemo tenetur.}

Não há obrigação de responder as perguntas sobre os fatos que deram origem à notícia, quando das respostas o jornalista puder ser responsabilizado criminalmente.

A garantia do direito ao silêncio, no sentido de não colaborar, de não fazer prova contra si mesmo, contido nos Tratados Internacionais de Direitos Humanos, ratificados pelo Brasil, estende-se àquele profissional na condição de testemunha, não obstante seu depoimento seja parcial, já que pode recusar-se a identificar a fonte de informação.

A Comissão Americana de Direitos Humanos, no seu art. $8^{\circ}, \S 2^{\circ}$ diz que "Durante o processo toda pessoa tem direito, em plena igualdade, às seguintes garantias mínimas: (...). g) direito de não ser obrigada a depor contra si mesma, nem a declarar-se culpada". Sem dúvida que a garantia abrange a declaração oral da testemunha, como pessoa que participa da instrução criminal $^{565}$, bem como a recusa de entrega do material jornalístico cujo conteúdo poderá incriminá-la.

O jornalista pode invocar seu direito de não responder determinada pergunta para não se auto-incriminar. É preciso, no entanto, que se esclareça. O princípio do nemo tenetur se ipsum accusare aplica-se a parte do depoimento na qual o jornalista tem o dever de dizer a verdade, ou seja, sobre os fatos que não impliquem a identificação da fonte ou possa levar à sua descoberta, pois, quanto à não revelação da fonte, a própria regra constitucional o ampara. ${ }^{566}$

${ }^{565}$ O Pacto Internacional de Direitos Civis e Políticos, no entanto, em seu art. 14, § $3^{\circ}$, g, em redação mais restrita dispõe: "toda pessoa acusada de um delito terá direito, em plena igualdade [...] a não ser obrigada a depor contra si mesma, nem a confessar-se culpada".

${ }^{566}$ No processo civil, o direito de não se auto acusar é conferido pelo art. 406, o qual desobriga a testemunha de declarar fatos "que lhe acarretem grave dano [...]". Moacyr Amaral Santos entende que na expressão dano inclui-se dano moral, como a honra, ou patrimonial. Esclarece: "Impor à testemunha, num processo em que se discute interesses de terceiros, desvende a própria desonra, conte a própria torpeza ou confesse um crime [...] seria constrangê-la, a ela que colabora com a Justiça, a um sacrificio tal que, no mais das vezes, 
Não significa, no entanto, um absoluto silêncio sobre os fatos, mas tão só a negativa de revelar fato próprio, decorrente de questionamento específico feito por qualquer das partes, ou pelo magistrado. ${ }^{567}$ Nessa situação, o jornalista deverá justificar sua recusa a não responder, sem que seja obrigado a fazer com precisão de detalhes, para não correr o risco de fornecer elementos que o incriminem. ${ }^{568}$

\subsection{Jornalista: testemunha de "ouvir dizer".}

O profissional que publicou a notícia, na maior parte das vezes, narra fatos os quais "ouviu dizer" de outrem, da fonte que lhe informou. Não obstante deva conferir, "checar a veracidade" das informações para dar credibilidade à publicação, os fatos não foram pessoal e imediatamente percebidos por ele.

Trata-se de uma testemunha indireta, que não reproduz aquilo que, originariamente, percebeu do fato a ser provado. ${ }^{569}$ A rigor, nem mesmo é uma "testemunha", no sentido etimológico do termo, que é a pessoa que obteve percepção própria, direta, dos fatos ocorridos no passado, os quais devem ter sua existência confirmada ou negada no processo. O jornalista, como declarante, comunica uma própria percepção, não da ocorrência dos fatos, mas do que percebeu da afirmação de terceiro. ${ }^{570}$

a levaria ao perjúrio". Cf. Comentários ao Código de Processo Civil. $3^{\mathrm{a}}$ ed., a., Forense: Rio de Janeiro, 1982, v. IV, p. 276.

${ }^{567}$ Segundo Paolo Tonini, o pressuposto do privilégio contra a autoincriminação "é a simples probabilidade de que da resposta sobre um determinado fato derive a responsabilidade penal do declarante; não é suficiente que possa derivar somente uma responsabilidade civil ou administrativa”. Cf. A prova...cit., p. 127. No mesmo sentido, sobre as declarações da persona non imputata, Cf. GREVI, Vittorio. Nemo tenetur se detegere. Interrogatorio dell'imputato e diritto al silenzio nel processo penale italiano. Milano: Giuffrè, 1972, p 180 , nota 87.

568 TONINI, Paolo. A prova...cit., p. 127.

${ }^{569}$ MAGALHÃES GOMES FILHO, Antonio; BADARÓ, Gustavo Henrique Righi Ivahy. Prova e sucedâneos de prova no processo penal brasileiro. Revista Brasileira de Ciências Criminais. n. 65. São Paulo: Revista dos Tribunais, março-abril de 2007, p. 189.

570 CALAMANDREI, Iolanda. Titolo I. Mezzi di prova. Capo I. Testimonianza. Commento. In: CHIAVARIO, Mario (Coord). Commento al nuovo codice di procedura penale. Torino: UTET, 1990, p. 429. Enfatiza a autora, que por razões lógicas, da própria definição do meio probatório - prova testemunhal -, o problema do testemunho indireto nem sequer deveria poder ingressar no processo. (pp. 429-430). 
Em juízo, alegando o sigilo da fonte, os fatos declarados pelo jornalista não podem ser confirmados ou infirmados através de uma testemunha referida (art. $209, \S 1^{\circ}$ ) ${ }^{571}$, na qual estaria a origem da informação. O testemunho de relato ${ }^{572}$ pode ser válido para a descoberta da testemunha presencial. Todavia, o direito de o profissional não revelar a identidade da pessoa que teve conhecimento direto do fato, não possibilita um testemunho com elementos seguros de informação, mas tão somente uma "cognição reflexa" consistência necessária para a formação da verdade processual.

A questão do testemunho indireto foi enfrentada, pela primeira vez em nível legislativo, no novo Código de Processo Penal italiano. O art. 195, inciso 7, determina que a testemunha indireta indique a pessoa ou entregue o documento que deu origem à informação trazida no depoimento, sob pena de não poder ser utilizado, não poder ser valorado o testemunho. No caso de a testemunha direta não poder depor, nas hipóteses de doença, morte ou desconhecimento do seu paradeiro (inciso 3), o depoimento de relato poderá ser sopesado, confrontado com o exame das demais provas. ${ }^{574} \mathrm{O}$ legislador italiano, no entanto, no inciso 6, repetiu a proibição probatória referente aos segredos profissionais e de Estado.

Entre nós, o testemunho do jornalista, como prova indireta, deverá ser valorado pelo juiz para formar sua convicção. Se o profissional revelar a fonte da informação, o magistrado, a seu critério, poderá ouvir como testemunha a pessoa que, em princípio, conheceu pessoalmente os fatos. É o que dispõe o $\S 1^{\text {o }}$ do art. 209 do CPP.

Não há dúvida, no entanto, de que, se o jornalista insiste em manter anônima a fonte, a impossibilidade de as partes poderem ter conhecimento da origem dos fatos, a

\footnotetext{
${ }^{571}$ Segundo Os aldo Trigueiro do Valle Filho, a "testemunha referida é exatamente isso, quer dizer, tem-se a oportunidade de conhecer de perto os fatos, porém fica-se refém de uma discricionariedade que passa a ser agressiva, que há de ser superada". Cf. A ilicitude da prova. Teoria do testemunho de ouvir dizer. São Paulo: Revista dos Tribunais, 2004, p. 318.

572 Termo utilizado pela jurisprudência italiana para referir-se à testemunha de "ouvir dizer". Cf. Cass., 12 giugno 2003 - 2 ottobre 2003, n. 37434, CED 226036; CP 05, 151.

${ }_{573}^{77}$ MAGALHÃES GOMES FILHO, Antonio; BADARÓ, Gustavo Henrique Righi Ivahy. Prova e sucedâneos...cit., p. 189.

574 Nessas hipóteses, a jurisprudência italiana entende que as declarações da testemunha indireta são consideradas indícios: Cass., sez I, 15 luglio 2009 - 9 settembre 2009, n. 35016, CED 245187. Em sentido contrário, de que valem como comprovação direta do fato, após preenchidos os requisitos do art. 195 do CPP: Cass., sez. II, 17 gennaio 1997 - 28 maggio 1997, n. 4976, Accardo, CED 207843.
} 
admissão de um testemunho eventualmente fundado em rumores ${ }^{575}$, interesses pessoais, destituído de uma realidade mais próxima da verdade do que ocorreu, ofende o contraditório, pois as partes não poderão questionar a fonte e, portanto, não se compatibiliza com um processo penal acusatório, como esculpido pela Constituição de $88 .^{576}$

A solução possível, adequada a um processo penal constitucional, diante da inexistência de contornos legislativos para a questão da testemunha indireta no sistema processual penal brasileiro, é considerar inadmissível o testemunho do jornalista, tratá-lo como prova inválida para o convencimento judicial ${ }^{577}$, se a fonte da informação não for identificada. ${ }^{578}$ Com efeito, boatos, fraudes, interesses escusos eventualmente contidos em informações anônimas, ${ }^{579}$ violam direitos personalíssimos dos indivíduos acusados de crimes e não podem justificar uma busca da verdade processual que deve reger-se por parâmetros de licitude e justiça.

Mas só aparentemente é tranquila a solução apontada. Para que a prova seja considerada não válida, é preciso que as declarações do profissional provenham de uma única fonte, o que não é - não deveria ser! - o método de trabalho do jornalismo investigativo que busca "provas" confirmadoras das notícias que "denunciam” práticas criminosas. Assim, se o jornalista se recusa a identificar a origem da notícia, mas fornece documentos comprobatórios das acusações que integram a publicação midiática e,

575 O caso Jayson Blair, repórter do New York Times, é bastante ilustrativo quanto ao problema da manipulação das informações. Em 2003 descobriu-se que esse jornalista, sem citar a fonte, construía reportagens de fatos nunca existentes, abalando a credibilidade do meio informativo, fazendo com que o jornal tomasse medidas para recuperar a confiança dos leitores. Disponível em http://www.nytimes.com/2003/05/11 national/11PAPE.html?pagewanted=10\&ei=5070\&en=1179288000.

Acesso em 17 de junho de 2011.

${ }^{576}$ VALLE FILHO, Oswaldo Trigueiro. A ilicitude da prova ... cit., p. 357.

577 MAGALHÃES GOMES FILHO, Antonio; BADARÓ, Gustavo Henrique Righi Ivahy. Prova e sucedâneos...cit., p. 189.

578 Segundo Adrian Ventura, os Tribunais americanos, diante da negativa de revelação das fontes, pelos jornalistas, mesmo com a possibilidade de pena de prisão, para convencê-los a identificar a origem das informações, decidem, como uma das alternativas para contornar a dificuldade, que" se não querem expor a fonte, é porque ela não existe”, “o que equivale a dizer que a fonte foi fabricada”, surgindo, daí, a obrigação de os meios de comunicação pagarem grandes indenizações pela falsidade da informação publicada, porque não pode ser provada. Cf. Libertad de expresion...cit., p. 169, nota 21.

${ }^{579}$ Diz Sofia Pinto Coelho que "ser enganado é um risco que o jornalista corre, mas com o qual tem de saber conviver - e, sobretudo, contra o qual tem de saber prevenir-se. A acontecer, não pode sucumbir à (humanamente compreensível...) tentação de castigar alguém ou de se vingar ; deve, sim, assumir humildemente o erro, corrigi-lo perante o público leitor a quem deu a informação errada - é sempre o jornalista quem dá a informação, não é a fonte”. Cf. Jornalistas e Tribunais. Lisboa: Quetzal, 2005, p. 219. 
inclusive, dá o nome de outras pessoas - fontes "on the record" - que conhecem algum detalhe dos fatos, a questão, a nosso ver, não é de invalidade da prova, mas de valoração.

Nessa hipótese, as declarações do jornalista são seguramente utilizáveis, devem ser admitidas no processo, mas não se exime o julgador de avaliá-las com critério e prudência para fundamentar sua decisão. Isso porque a percepção do jornalista, acerca da percepção dos fatos relatados pelo informante, é voltada para a notícia, não só para a o direito e dever de informação que decorrem da liberdade de imprensa, mas também para o entretenimento. Assim, os detalhes que são apreendidos pelo repórter, do que foi relatado pelo informante, são aqueles de interesse midiático, de exclusividade, de repercussão pública, o que, não necessariamente, será relevante como prova do fato objeto do procedimento penal.

E exatamente em razão desta "percepção midiática" dos fatos percebidos, é que as partes devem ponderar se as circunstâncias do caso justificam a utilidade do testemunho do jornalista, pois nem sempre proporciona elementos firmes e seguros de convicção para o julgador. Só excepcionalmente, se outros meios de prova não tiverem êxito para a investigação de um crime ou na busca da verdade processual, os canais midiáticos devem ser utilizados como meios probatórios.

\subsection{A busca e apreensão do material de trabalho e a intercepção telefônica do jornalista}

Os materiais jornalísticos utilizados para fazer a reportagem, documentos eletrônicos ou não, gravações de áudio e fitas de vídeo, poderão ser solicitados pelo juiz ao jornalista ou à empresa para o qual ele trabalha. A recusa em fornecê-los, porque "as redações dos jornais são também depositárias de segredos profissionais" "580, está amparada constitucionalmente, como já viemos discorrendo no desenvolvimento deste trabalho. ${ }^{581} \mathrm{E}$

\footnotetext{
${ }^{580}$ PRADERA, Javier. La extraña pareja...cit., p. 38.

${ }^{581}$ Diego Fajardo Maranha Leão de Souza menciona o art. 363, IV do Código de Processo Civil o qual dispõe que: "a parte e o terceiro se escusam de exibir, em juízo, o documento ou a coisa [...] se a exibição acarretar a divulgação de fatos, a cujo respeito, por estado ou profissão, devam guardar segredo". Para o autor, "a ratio dessa norma, através de uma aplicação analógica ao processo penal com base no art. $3^{\circ}$ de seu código de regência, é um bom indicador do caminho a ser seguido quando a busca ou requisição envolverem elementos protegidos pelo sigilo". Cf. Sigilo profissional ...cit., p. 143. A nós parece não aplicável ao sigilo da fonte do
} 
o sigilo não pode ser quebrado em nome da busca da verdade processual, se o jornalista ou a empresa não possuem o dever de cooperar. ${ }^{582}$

Todavia, as empresas de comunicação, ou quem exerce profissionalmente a atividade àquela relacionada, devem atender às requisições judiciais de entrega de documentos e informações que não violem o sigilo necessário ao exercício da profissão, tampouco possam, indiretamente, levar à identificação do informante. ${ }^{583}$ A nosso ver, eles não estão obrigados a apresentarem os escritos, as gravações e filmagens "em bruto", podendo invocar o caráter sigiloso do material requisitado, bem como a necessidade de serem protegidos "no âmbito e pela finalidade a que se dirige o sigilo profissional" 584 .

Se, para preservar a identidade da fonte, admite-se a escusa de fornecer material jornalístico, não teria sentido, por consequência, determinar-se a busca e apreensão de documentos que tenham servido para elaborar a reportagem, pois violaria a regra do sigilo, o qual se pretende proteger. ${ }^{585}$ Ainda que nesses documentos ou informações possam conter elementos demonstrativos de crimes, obtê-los com a quebra do sigilo assegurado ao profissional da mídia, em primeiro plano carece de ética, valor do qual não prescinde um instrumento público como o processo penal. ${ }^{586}$

Evidente que a busca e apreensão dos escritos e demais documentos na redação do jornal ou domicílio do jornalista reveste-se de legalidade, quando é ele o investigado ou

jornalista, pela peculiaridade desse em relação aos demais sigilos, mencionado no item 3.1 do presente capítulo.

582 FRANCO, João Melo. Conceitos e princípios jurídicos: na doutrina e jurisprudência. Coimbra: Almedina, 1983, p. 679.

${ }^{583}$ Essa situação é compatível com o exposto acerca da obrigatoriedade de o jornalista depor sobre os fatos relacionados ao objeto do processo penal, com a salvaguarda do sigilo profissional. Vide item 5.5 do presente capítulo.

${ }^{584}$ O Parecer PGR 760 (n. convencional) faz menção à regra segundo a qual "o jornalista ou o director da respectiva empresa não é obrigado a exibir ou fornecer, independentemente de a fonte ser pessoal, ou documental ou outra, os elementos recolhidos, nomeadamente as gravações em bruto (...)."Cf. em Conselho Consultivo da PGR. Segredo profissional. Relator Lourenço Martins. 1996, p. Disponível em http://www.dgsi.pt/pgrp.nsf/Por+Relator/CC7FEF6DA3B0120280256617004258C1/? Acesso em 23de outubro de 2010.

585 O Tribunal Europeu de Direitos Humanos, no caso de um jornal de Estambul: Özgür Gündem - vs. Turquia (2000) entendeu desproporcional a medida consistente em "requisitar os arquivos, a documentação e a biblioteca do jornal”. Cf. VENTURA, Adrian. Libertad...cit., p. 253.

${ }^{586}$ PITOMBO, Cleunice Bastos. Da busca e apreensão no processo penal. $2^{\mathrm{a}}$ ed. r.a.a. São Paulo: Revista dos Tribunais, 2005, p. 167. 
acusado de delito. ${ }^{587}$ Também não fica excluída a legalidade da medida se em poder do profissional estiver o corpo do delito o qual se investiga ou é objeto do procedimento penal. Desde que seja preservada a fonte, é possível a apreensão de algum documento ou qualquer objeto, vestígio deixado pelo crime, que esteja na posse do jornalista.

Pressuposto essencial dessa busca é que existam "fundadas razões a autorizarem" ( $\$ 1^{\circ}$ do art. 240 do CPP), isto é, elementos fortes e concretos para legitimar a cautela, informações suficientes para se acreditar que na redação do jornal, ou no domicílio do repórter, encontra-se objeto determinado que precise ser apreendido, porque compõe o corpo do delito.

Fica excluída a possibilidade de apreensão de computadores ${ }^{588}$, notas, cadernos contendo informações ${ }^{589}$ - salvo se eles constituírem objeto ou elemento de um crime praticado pelo jornalista -, pois viola regras constitucionais e a prova obtida é ilícita, sequer pode ser admitida no processo e, tampouco, serve para fundamentar a sentença judicial. ${ }^{590}$

${ }^{587}$ A Corte Europeia dos Direitos Humanos considerou que a busca nos domicílios de um jornalista e de sua advogada, ordenada pela Justiça criminal de Luxemburgo, com o fim de identificar a fonte de informação, viola o art. 10 da CEDH. Cf. Caso Roemen y Schimit vs. Luxemburgo (sentença de 25.02.2003). No parágrafo 47 da sentença, o Tribunal ressaltou que a busca e apreensão feita no domicílio ou em local de trabalho do jornalista, para identificar a fonte de uma informação sigilosa- embora essa divulgação caracterize conduta criminosa -, é uma ingerência dos direitos garantidos no parágrafo $1^{\circ}$ do art. 10 da CEDH. Além do mais, há outros meios para encontrar o autor da violação do segredo profissional. No mesmo sentido foi a decisão do caso Ernst y outros vs. Bélgica, de 15 de julho de 2003. Disponível em http://www.echr.coe.int/echr/. Acesso em 28 jul. de 2011.

${ }^{588}$ Em 27 de Abril de 2004, em virtude de uma investigação de um atentado ao consulado brasileiro em Santiago do Chile, ordem judicial determinou a apreensão de dois discos rígidos de computadores do jornal digital chileno "El Mostrador", cujos conteúdos foram copiados para análise e averiguação da existência de um e-mail que reivindicava o atentado. O "El Mostrador", após o atentado, teria recebido esse e-mail do Movimento de Esquerda Revolucionária, mas a participação do grupo foi negada por um dos líderes, também em e-mail enviado para o jornal. Cf. "Confiscados discos de computador a jornal digital”. Sítio do Sindicato dos Jornalistas, 30.04.2004. Disponível em http://www.jornalistas.online.pt. Acesso em 23 de novembro de 2011.

${ }^{589}$ O Conselho Consultivo da Procuradoria Geral da República de Portugal emitiu parecer no sentido de que "os jornalistas da televisão têm igualmente direito, nos termos da lei, à protecção do sigilo profissional, questão, aliás, que não vem nem se afigura dever ser posta em dúvida", de onde decorre que a eles se aplica o art. $7^{\circ}$, n. 3 do Estatuto do Jornalista, no qual consta não serem, em qualquer lugar ou momento "desapossados do material utilizado (por exemplo, câmaras fotográficas ou de filmar) ou obrigados a exibir os elementos recolhidos, a não ser por mandado judicial, nos temos da lei” (alínea b). Cf. Parecer PGR 760 (n. convencional). Segredo profissional. Relator Lourenço Martins. Disponível em http://www.dgsi.pt/pgrp.nsf/Por+Relator/CC7FEF6DA3B0120280256617004258C1/? Acesso em 23 de outubro de 2010.

${ }^{590}$ GRINOVER, Ada Pellegrini; MAGALHÃES GOMES FILHO, Antonio; SCARANCE FERNANDES, Antonio. As nulidades...cit., p. 163; Não há que se falar aqui de nulidade, mas de inadmissibilidade da prova obtida por meio ilícito. Essa "constitui sanção de natureza processual, ligada à questão da validade e eficácia (ou, por oposição, da invalidade e ineficácia) dos atos processuais. Ao contrário da nulidade, que visa a retirar os efeitos de um ato regularmente praticado, a inadmissibilidade atua de forma antecipada, impedindo 
Na esteira da ilicitude da prova obtida com violação do sigilo da fonte, também é inadmissível a interceptação da comunicação telefônica do jornalista, mesmo quando se trate de investigação policial de gravíssimos crimes. Se houver autorização judicial nesse sentido, restritiva do direito de informação e com a ofensa ao sigilo da fonte, a prova colhida por esse meio deve ser considerada ilícita. Tampouco é possível a quebra do sigilo telefônico do jornalista, pois a fonte poderá ser identificada, ainda que o fundamento da medida seja a correta apuração de fatos delituosos.

O Tribunal Europeu dos Direitos do Homem ressaltou na decisão do Caso Malone versus Reino Unido que o segredo das comunicações telefônicas abrange o conteúdo da conversação ou comunicação e a identidade dos interlocutores. ${ }^{591}$ Portanto, em nenhuma medida, nem mesmo para identificar a fonte, pode ser determinada a interceptação da comunicação telefônica do jornalista, porque é inviolável, não somente a mensagem, mas todos os dados que identifiquem os interlocutores. ${ }^{592}$

Ressalte-se, neste ponto, que esse meio de busca de elementos probatórios, dentro dos limites legais, não tem vedada sua realização, quando o jornalista é o investigado ou acusado de crime.

o ingresso no processo do ato regular. No caso das provas ilícitas, a inadmissibilidade processual funciona como mecanismo preventivo, destinado a evitar que as violações ao direito material se consumem, diante da indicação clara e antecipada feita pelo legislador, no sentido de que os dados probatórios resultantes de condutas contrárias ao direito não terão ingresso no processo, não podendo servir à formação do convencimento judicial". Cf. MAGALHÃES GOMES FILHO, Antonio. Provas ilícitas e recurso extraordinário. In: PENTEADO, Jaques Camargo (Coord.). Justiça Penal. Críticas e sugestões. Provas ilícitas e reforma pontual. São Paulo: Revista dos Tribunais, 1997, p. 33.

${ }^{591}$ Citado por RODRIGUES, Benjamim Silva. Das escutas telefônicas...cit., p. 82.

${ }^{592}$ RODRIGUES, Benjamim Silva. Das escutas telefônicas...cit., p. 83. 


\section{SIGILO DA FONTE: UM LIMITE PROBATÓRIO (IN) SUPERÁVEL?}

O tema do segredo jornalístico ecoa profundamente no campo do processo penal, com grandes discussões não apenas teóricas, mas de atual importância prática para o futuro do direito à informação e para uma necessidade de realização da justiça. É nesse ponto de intersecção - ampla liberdade de imprensa e acertamento de uma verdade processual justa - que se acirra o debate sobre ser absoluto ou relativo o sigilo da fonte, com apresentação de inúmeras razões favoráveis ou contrárias a essa espécie particular de segredo.

O consenso doutrinário e jurisprudencial acerca da questão está longe de ser atingido, sobretudo porque o status jurídico constitucional do sigilo jornalístico parece protegê-lo de intervenções limitativas do legislador, sempre vistas, politicamente, como espécies de agressão.

Desde uma solução basicamente jurisprudencial nos Estados Unidos da América, de ponderação de valores, onde a Primeira Emenda à Constituição assegura uma verdadeira e quase ilimitada liberdade de expressão, enquanto a Quarta Emenda atribui a todos um processo justo e equitativo, até legislações europeias que vão desde a negativa do segredo até uma normatização detalhada como no Processo Penal Português, os problemas detêm-se sobre o limite da confidencialidade da fonte: sim ou não ${ }^{593}$

Nas legislações processuais penais da Itália e de Portugal, a regulamentação do sigilo jornalístico é muito precisa, e pode oferecer dados para encontrarmos um caminho, ao menos como um ponto de partida para o estudo do tema entre nós.

Analisaremos, também, algumas questões contemporâneas que possuem relação com o tema, como do testemunho do jornalista no processo penal de crimes contra a humanidade, e do segredo da fonte na informação que é transmitida pelos meios tecnológicos, como a internet.

${ }^{593}$ CARRILLO, Marc. La clausula de conciencia y el secreto profesional...cit., p. 73. 


\subsection{A regulamentação do segredo jornalístico no Código de Processo Penal Italiano}

O direito de o jornalista escusar-se a indicar a fonte da notícia que publicou, quando no processo penal era inquirido pelo juiz, derivava de normas deontológicas no sistema jurídico italiano. ${ }^{594} \mathrm{O}$ artigo 351 do CPP elencava as pessoas que poderiam abster-se de testemunhar em virtude do segredo profissional, mas não fazia referência aos jornalistas. ${ }^{595}$

A nova sistemática do CPP Italiano de 1988 dispôs no art. 200, item 3, que as normas referentes aos demais segredos se aplicam aos jornalistas profissionais, relativamente aos nomes das pessoas das quais eles receberam notícias, sob confiança, no exercício da profissão. Assim, eles não podem ser obrigados, quando testemunhas, a identificar a pessoa que lhes forneceu a notícia, exceto na hipótese em que seja a única prova possível em relação ao fato objeto do processo penal. ${ }^{596}$

O segredo profissional é estendido aos jornalistas, com alguns limites. É preciso que eles estejam inscritos no respectivo órgão de classe, portanto, devem ser jornalistas profissionais; somente os "nomes das pessoas" das quais se originaram a notícia recebe a tutela da confidencialidade ${ }^{597}$; se a veracidade dos fatos que estão sendo apurados no processo penal só for possível com a identificação da fonte, essa se impõe ao jornalista.

\footnotetext{
594 A Lei n. 69, de 03 de fevereiro de 1963, era a única fonte normativa sobre o segredo profissional dos jornalistas, em cujo art. 2 vem prescrito, para esses a obrigação deontológica "do segredo sobre a fonte das notícias, quando colhidas sob confiança dessa". Havia crítica da doutrina em relação à ausência de regulamentação desse segredo no sistema jurídico, considerada uma "vistosa anomalia", não resolvida nem mesmo pela jurisprudência que não hesitou, em vários casos, determinar a prisão do jornalista que se recusou a identificar a fonte de informação. Cf. GROSSO, Carlo Frederico. Sviluppi recenti del diritto penale della informazione a mezzo stampa. In: Boletim da Faculdade de Direito. Universidade de Coimbra, 1989, v. LXV, p. 301.

${ }^{595}$ NUVOLONE, Pietro. Il segreto...cit., p. 101; Para Aurelia María Romero Coloma, em sentido contrário, aduz que o art. 351 do antigo CPP Português não tinha o caráter taxativo e, portanto, aplicava-se aos jornalistas. Cf. Derecho y deber de reserva y libertad de informacion en el ordenamiento jurídico penal italiano. In: Actualidad Penal. n. 41, Alcobendas (Madrid), 13 noviembre 1988, p. 2153.

${ }^{596}$ Art. 200, 3: "Le disposizione previste dai commi 1 e 2 se applicano ai giornalisti proffessionisti iscritti nell albo professionale, relativamente ai nomi delle persone dalle quali i medesimi hanno avuto notizie di carattere fiduciário nell esercizio della loro professione. Tuttavia se le notizie sono indispensabili ai fini della prova del reato per cui si procede e la loro veridicità può essere accertata solo attraverso l'identificazione della fonte della notizia, Il giudice ordina al gironalista di indicare la fonte delle sue informazione".

${ }^{597}$ Decidiu a Corte Italiana que "O segredo dos jornalistas profissionais está circunscrito à indicação do nome da fonte, em cujo âmbito inclui-se qualquer indicação que possa levar à sua individualização". (Cass., sez I, 16.02.2007 - 4.07.2007, n. 25755, CED 237431). Cf. LATANZI, Giorgio. Codice...cit., p. 725.
} 
Prefere o legislador o interesse da justiça ao direito à informação ${ }^{598}$, mas submetidos à avaliação judicial, como dispõe o inciso 2 do art. 200 do Código de Processo Penal: "o juiz, se tem motivo para duvidar que a declaração da pessoa para eximir-se do depoimento seja infundada, provê aos acertamentos necessários. Se resulta infundada, ordena que a testemunha deponha". 599

A norma também é aplicável no caso de aquisição de prova documental, que pode levar ao comprometimento do direito de não identificar a fonte jornalística. E, se as razões apresentadas pelo profissional para não consentir com a entrega do material de trabalho forem destituídas de fundamento, o juiz determina a busca e apreensão, a qual, no entanto, “deverá ser conduzida de modo a não comprometer o direito do jornalista à reserva da correspondência e da própria fonte". 600

Na hipótese de o jornalista se negar a revelar a fonte e o juiz entender que há outros meios para o esclarecimento dos fatos averiguados, o testemunho não será processualmente utilizado, pois indireto e, como tal, violaria a proibição expressa do art. 195 do Código de Processo Penal. ${ }^{601}$

Dessume-se, portanto, que o segredo profissional do jornalista no CPP italiano é um direito limitado, entendendo Giorgio Spangher que o intuito do legislador foi evitar que

\footnotetext{
598 Argumenta Paolo Tonini que "a diversidade de tratamento do jornalista está no fato de que ele exercita uma profissão a qual o indivíduo não tem a necessidade de recorrer; portanto, o interesse do indivíduo não prevalece em relação ao interesse da administração da justiça". Cf. A prova...cit., p. 135.

599 Enzo Musco assinala que um dos aspectos negativos da nova disciplina processual,é o relacionado ao conceito de "indispensabilidade" do testemunho para provar o delito objeto do processo penal, pois a flexibilidade do termo leva ao risco de interpretações caracterizadas por forte subjetivismo. Cf. Justicia Penal y Libertad de prensa. Entre verdad y secreto. In: Justicia Penal y Libertad de Prensa, Tomo 1, p. 275. Ilanud, San José, Octubre de 1993. http//www.ilanud.or.cr/centro-de-documentacion/biblioteca-digital/176justicia-penal-y-libertad-de-prensa.html. Sobre o tema da liberdade de imprensa na Itália, ver estudo detalhado do mesmo autor em: Justicia Penal y Libertad de prensa. Informe sobre Italia. In: Justicia Penal y Libertad de Prensa, Tomo 1, p. 587-623. Ilanud, San José, Octubre de 1993. http//www.ilanud.or.cr/centrode-documentacion/biblioteca-digital/176-justicia-penal-y-libertad-de-prensa.html.

${ }^{600}$ Decisão da Corte Italiana no caso em que se procedeu ao "sequestro probatório da memória do personal computer de um jornalista que alegou segredo profissional”. (Cass., sez. I, 16.02.2007 - 4.07.2007, n. 25755, CED 237430). Cf. LATANZI, Giorgio. Codice...cit., p. 725.

${ }^{601}$ Art. 195, 7: "Non può essere utilizzata la testimonianza di chi si rifiuta o non è in grado di indicare la persona o la fonte da cui há appreso la notizia dei fatti oggetto dell'esame". Pietro Nuvolone entende que a garantia da não valoração do testemunho é só aparente, pois uma vez que a prova foi introduzida no processo penal, influenciará o convencimento judicial. Para ele, melhor seria que, antes de assumi-lo como testemunha, o juiz perguntasse ao jornalista sobre a intenção de valer-se do direito ao sigilo da fonte, impedindo a introdução da prova, em caso afirmativo. Cf. Il segreto...cit., p. 103.
} 
notícias importantes pudessem ser criadas ou distorcidas, ou pudesse aquele se esconder atrás de um informante, de uma fonte inexistente. ${ }^{602}$

\subsection{O incidente de quebra de escusa do depoimento jornalístico no Código de Processo Penal português}

No processo penal português há regulamentação expressa e detalhada dos termos em que, excepcionalmente, pode ocorrer a quebra do sigilo profissional do jornalista. ${ }^{603} \mathrm{O}$ legislador, no art. 135, fez uma separação funcional para a decisão sobre o procedimento de escusa de depoimento, atribuindo ao tribunal de primeira instância a avaliação sobre a legitimidade e ao tribunal superior caberá decidir sobre a justificação. ${ }^{604}$

Assim, na estrutura procedimental do incidente, o juiz ordena a prestação de depoimento, pois declara ilegítima a escusa em razão do segredo profissional. No entanto, se entender pela legitimidade da recusa ao dever de depor, prescinde do testemunho e determina ex oficio a subida ao tribunal de recurso para análise da justificação. De qualquer maneira, somente o tribunal de primeira instância decide sobre a legitimidade da escusa e a justificação é de atribuição exclusiva do tribunal superior ${ }^{605}$, o qual pode ordenar a quebra do segredo se "justificada, segundo o princípio da prevalência do interesse preponderante, nomeadamente tendo em conta a imprescindibilidade do depoimento da descoberta da verdade, a gravidade do crime e a necessidade de proteção de bens jurídicos" (art. 135, n. 3). "Essa é a verdadeira questão da quebra do segredo profissional (acórdão do TC n. 7/87), uma vez que a questão da legitimidade é meramente formal". 606

${ }^{602}$ Cf. Titolo I. Mezzi di prova. Capo I. Testimonianza. Commento. In: CHIAVARIO, Mario (Coord). Commento al nuovo codice di procedura penale. Torino: UTET, 1990, vol. II, p.464.

${ }^{603}$ O Código de Processo Penal português sogreu a $15^{\mathrm{a}}$ alteração pela Lei 48/2007.

604 Paulo Pinto de Albuquerque esclarece que a questão correta sobre o procedimento foi fixada pela jurisprudência do Supremo Tribunal de Justiça, n. 2/2008, em cujo acórdão referente a informações sobre conta de depósito em instituição bancária determinou-se que o tribunal de primeira instância decide sobre a legitimidade da escusa e ordena, se o caso, a prestação de informações nos termos do n. 2 do art. 135 do CPP. Caso a escusa seja legítima, a quebra do segredo será decidida pelo tribunal superior ou perante o Supremo Tribunal de Justiça, nos termos do n. 3 do art. 135. Diz o autor que essa jurisprudência deve ser seguida em relação a todos os segredos, exceto o religioso. Cf. Comentário ao Código de Procecesso Penal...cit., p. $361 / 362$.

${ }^{605}$ ALBUQUERQUE, Paulo Pinto de. Comentário ao Código...cit., p. 361.

${ }^{606}$ ALBUQUERQUE, Paulo Pinto de. Comentário ao Código....it., p. 363. 
O princípio da prevalência do interesse preponderante é, pois, princípio geral que vai nortear a matéria da justificação. ${ }^{607}$ Manuel Lopes Maia Gonçalves adverte sobre a necessidade de o tribunal superior decidir com muito critério, prudência e moderação sobre a justificação da escusa, tendo em vista os relevantes interesses em jogo, exigências de uma correta administração da justiça e de tutela do segredo profissional. ${ }^{608}$ Trata-se de uma imposição legal do regime-regra a tutela do sigilo, que se relativiza por exigências do princípio da verdade material. ${ }^{609}$ A vedação de produção de prova testemunhal, na hipótese, será submetida à valoração daqueles interesses pelo Poder Judiciário. ${ }^{610}$

Relevante, ainda, é a previsão normativa segundo a qual a autoridade judiciária decidirá sobre a legitimidade do pedido de escusa de depor após "ouvido o organismo representativo da profissão relacionada com o segredo profissional em causa, nos termos e com os efeitos previstos na legislação em que a esse organismo seja aplicável" (art. 135, n. 4 do CPP). Em Portugal, a competência para a emissão de pareceres relacionados ao segredo da fonte do profissional da mídia é atribuída ao Sindicato dos Jornalistas. ${ }^{611}$

${ }^{607}$ FIGUEIREDO DIAS, Jorge de. Direito Penal. Parte Geral. Tomo I: Questões fundamentais - A doutrina geral do crime. Coimbra: Coimbra Editora, 2004, p. 369.

608 GONÇALVES, Manuel Lopes Maia. Código de Processo Penal. Anotado. 10ª ed. rev. atual., Coimbra:Almedina, 1999, p. 335.

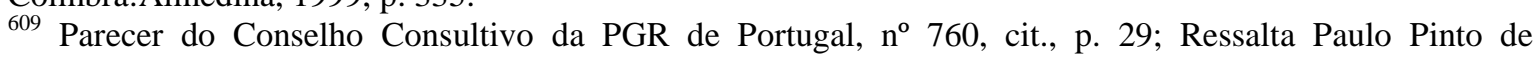
Albuquerque, que a " necessidade'de protecção de bens jurídicos identifica-se com uma necessidade social premente (pressing social need) de revelação da informação coberta pelo segredo profsissional, à luz da interpretação que o TEDH e o Comité de Ministros do Conselho da Europa têm feito do artigo $8^{\circ}$ da CEDH (acórdão do TEDH Sunday Times v. Reino Unido (N 2) (...). Os bens jurídicos a que a lei se refere são os bens jurídicos tutelados pela lei penal Portuguesa, mas a quebra do sigilo profissional só é justificável se corresponder a um interesse social premeete. Destarte, a revelação da informação sob segredo profissional não deve, em princípio, ser imposta quando se indicie a prática de crimes particulares, salvo se o crime tiver um impacto social notório. Por outro lado, não há qualquer necessidade social premente da quebra do sigilo profissional quando houver fundados motivos para crer na existência de causas de isenção da responsabilidade ou de extinção do procedimento criminal”. Cf. Comentário...cit., nota 9, pp. 363-364.

${ }^{610} \mathrm{O}$ Tribunal Constitucional Português pronunciou-se pela constitucionalidade da norma restritiva do direito ao sigilo profissional do jornalista. No acórdão 7/87 de 09 de 2001, antes mesmo da alteração do art. 135 do CPP, concluiu que em relação ao n. 2 do mencionado artigo, "dando à autoridade judiciária o poder de averiguar a legitimidade da escusa a depor por parte dos jornalistas, e, se concluir pela ilegitimidade, ordenar, ou requerer ao tribunal que ordene a prestação do depoimento, não viola o direito dos jornalistas à protecção do sigilo profissional consignado no n. 3 da CRP; e o n. 3 do mesmo artigo, possibilitando a quebra do segredo profissional dos jornalistas quando se verificarem os pressupostos referidos no art. 185 do CPP , isto é, sendo o segredo revelado no cumprimento de um dever jurídico, sensivelmente superior ou visar um interesse público ou privado legítimo, quando considerados os interesses em conflito e os deveres da informação que, segundo as circunstâncias, se impõem ao agente, se puder considerar meio adequado para alcançar aquele fim, também não constitui violação daquele direito”. Cf. SANCHES, Inês Raposo. Os Direitos Fundamentais dos Jornalistas...cit., nota 45, p. 41-42.

${ }^{611}$ Mister ressaltar, nesse ponto, a observação feita por João Zenha Martins no sentido de que o parecer do Sindicato dos Jornalistas não pode ser motivo para dispensar a participação direta do profissional perante o juízo de levantamento do segredo, aliás, a razão do incidente. Para o autor, é necessário que o jornalista apresente os motivos pelos quais invoca o sigilo da fonte, possibilitando a justa ponderação de direitos que 
Para o legislador, o órgão representativo é quem possui melhores condições para analisar a questão da escusa de depoimento à luz das regras estatutárias da profissão jornalista, atuando como um verdadeiro amicus curiae. Todavia, como o Código Deontológio dos Jornalistas Portugueses prevê que o profissional não deve revelar suas fontes confidenciais de informação, mesmo em juízo, a não ser que as notícias publicadas sejam falsas ${ }^{612}$, o organismo de classe desses profissionais manifesta-se, em todos os casos, contrário à revelação da fonte de informação. ${ }^{613}$ Mas o parecer, no entanto, não vincula o juiz ou tribunal como tem sido decidido na jurisprudência portuguesa, ${ }^{614}$ não obstante haja entendimento na doutrina que os artigos gerais do CPP não devem prevalecer à legislação especial relativa aos organismos que representam as profissões. ${ }^{615}$

Foi o Código de Processo Penal, lei infraconstitucional, que restringiu o direito fundamental de os jornalistas portugueses não revelarem suas fontes, sob pena de responderem por crime de desobediência ${ }^{616}$, se não o fizerem. No entanto, os profissionais, invariavelmente, recusam-se a levantar a confidencialidade da fonte informativa, sob o argumento de que a credibilidade do profissional é valor que deve preponderar.

será feita pelo Tribunal Superior. Assim, o incidente de quebra do sigilo deixa de ser "labor meramente rotineiro que a simples audição institucional pode potenciar, assegurando, além do mais, um exercício do contraditório fundamental à boa decisão do incidente", se se fizer atento às garantias de um processo equitativo, que extrapola o sentido formal para alçar-se a um processo justo. Cf. O segredo jornalístico...cit., pp. $125-128$.

${ }^{612}$ Art. 6 do CDJP, aprovado em 4 de maio de 1993. A "garantia de sigilo profissional" também consta do Estatuto do Jornalista (Lei n. 1/99, de 13 de Janeiro), no art. $6^{\circ}$ e no art. 11, n. 1, acrescentou-se que, "sem prejuizo do disposto na lei processual penal, os jornalistas não são obrigados a revelar as suas fontes de informação, não sendo o seu silêncio passível de qualquer sanção, directa ou indirecta".

613 Segundo Jorge Reis Novais, o Sindicato dos Jornalistas de Portugal, sistematicamente, considera que o sigilo profissional é um direito absoluto o qual, em quaisquer circunstâncias, não deve sofrer restrição. Tal entendimento não é constitucionalmente adequado, assim como ofende a ordem constitucional a condenação de um jornalista que se recusa a revelar a fonte de uma informação que "era praticamente irrelevante para a descoberta da verdade (...); não era indispensável para a defesa (...);podia ser facilmente obtida ou infirmada por via não restritiva do direito ao sigilo". Que não se pense, continua o autor, "que aqui há um qualquer maniqueísmo que pretenda fazer dos magistrados os maus da fita contra os jornalistas, os bons. É que, entre nós, tão ou mais freqüentes que as insuficiências judiciais apontadas são os abusos da liberdade de imprensa por parte de jornalistas, sempre ciosos dos seus direitos enquanto jornalistas, mas pouco ou nada escrupulosos quando se trata de considerar direitos fundamentais de terceiros, como sejam o direito à honra, à privacidade, ao bom nome ou à imagem". Cf. NOVAIS, Jorge Reis. In: FREITAS, Helena de Sousa. Sigilo profissional em risco. Análise dos casos de Manso Preto e outros jornalistas no banco dos réus. Coimbra: Minerva, 2006, p. 14-15 (Prefácio).

${ }^{614}$ Cf. Acórdão do Supremo Tribunal de Justiça, 21.04.2005, in C, Acs. do STJ XII, 12, 186.

${ }^{615}$ GONÇALVES, Manuel Lopes Maia. Código...cit., p. 335, nota 3.

${ }^{616} \mathrm{O}$ crime de desobediência vem previsto nos no s 1 e 2 do art. 360 do Código Penal Português. 
Mas não é o único argumento. No Caso Manso Preto, ${ }^{617}$ jornalista português condenado a onze anos de prisão porque, como testemunha no processo penal, desobedecera à determinação do Tribunal Superior de dar conhecimento da fonte de sua informação, além do argumento da preponderância do direito fundamental ao sigilo, a defesa também sustentou a escusa no direito de resistência previsto no art. 21 da Constituição, segundo o qual "todos têm direito de resistir a qualquer ordem que ofenda os seus direitos, liberdades e garantias".

O procedimento de quebra de escusa de depor é aplicável, do mesmo modo, quando se trata de apresentar à autoridade judiciária, "quando esta o ordenar, os documentos ou quaisquer objectos que tiverem na sua posse e devam ser apreendidos, salvo se invocarem, por escrito, segredo profissional (...)" (art. 182 , 1 e 2 do CPPP). A apresentação de material jornalístico como gravações, documentos ou objetos, poderá ser recusada se o jornalista ou o responsável pelo meio de comunicação, por escrito, invocar o segredo profissional.

Apesar de o sigilo profissional estar regulamentado no Código de Processo Penal português, a questão continua gerando muitos debates. Há críticas à tendência da autoridade judiciária para transformar o jornalista em instrumento auxiliar de investigação de crimes, fazendo com que a classe profissional reivindique uma proteção do sigilo nos termos dispostos no art. 135, 5 do CPP, para os sacerdotes das confissões religiosas. ${ }^{618}$

\subsection{O testemunho do jornalista nos processos de crimes contra a humanidade}

No contexto do processo penal internacional, a questão da relação entre mídia e Justiça também se impõe.

\footnotetext{
617 José Luíz Ferraz de Manso Preto, em 2002, publicou reportagens no jornal "Expresso" sobre agentes infiltrados em redes de tráfico de droga. Foi arrolado como testemunha de defesa dos irmãos Jaime e Mário Pinto, envolvidos em narcotráfico, caso cujo resultado da operação policial foi a apreensão de 4 toneladas de haxixe. Conforme relato de Helena de Sousa Freitas, as reportagens do jornalista questionavam as ações legais ou ilegais dos agentes infiltrados e o advogado dos acusados entendeu que o repórter poderia ter informações sobre aquelas ações, embora nunca tivesse noticiado fato referente aos dois irmãos. Manso Preto, posteriormente, acabou absolvido pelo Tribunal da Relação de Lisboa, sob o fundamento de que o direito à manutenção do segredo profissional é preponderante. Cf. Sigilo profissional...cit., pp. 39-40 e 46.

618 Cf. "Sindicato dos Jornalistas considera inconstitucional subaltermização do sigilo profissional" Disponível em http://www.jornalistas.online.pt/noticia.asp?idCanal=491\&id=1886, Acessado em 23.09.2010.
} 
Acredita-se que foram as crônicas, as reportagens sobre crimes de guerra que contribuíram para a existência de um tribunal penal internacional competente para julgar a prática de delitos na ex-Iugoslávia. Através das notícias, os fatos criminosos e seus autores foram levados à Justiça, e as primeiras investigações e acusações formais foram possíveis $^{619}$.

Miroslav Filipovic foi um dos jornalistas que publicou na revista "Danas" e em seu site na internet as perseguições feitas por Milosevic às minorias nacionais, bem como o plano para a utilização de armas iugoslavas para provocar uma nova guerra civil. A fronteira invisível de temas considerados tabus e sensíveis no momento político do Kosovo, não foi ultrapassada sem consequências. Acusado por espionagem e divulgação de falsas notícias, o repórter foi condenado a sete anos de prisão. Cumpriu pena por cinco meses até que foi libertado por decisão absolutória do Tribunal Superior. ${ }^{620}$

Slobodan Milosevic, então presidente da República Federal da Iugoslávia e comandante das forças armadas, e mais quatro de seus seguidores durante a guerra de Kosovo, foram condenados por crimes contra a humanidade perante o tribunal símbolo de resistência do Conselho de Segurança da ONU, - Tribunal Penal Internacional da ExIugoslávia, o primeiro após Nuremberg, criado "tendo por única função acusar as pessoas responsáveis por violações graves das leis humanitárias internacionais cometidas no território da ex-Iugoslávia"621.

A produção probatória desse Tribunal era normatizada pelo Regulamento de Provas e Procedimento do Tribunal para a Ex-Iugoslávia ${ }^{622}$ e aqui releva mencionar que a

\footnotetext{
${ }^{619}$ ARBOUR, Louise. O equilíbrio justo entre publicidade, direito à vida privada, segredo profissional e busca por justiça. In: Cidadania e Justiça. Ano 4, n. 9, $2^{\circ}$ semestre de 2000, p. 181.

${ }^{620}$ MANCERON, Gilles. Milosevic doit être jugé a La Haye. Entretien avec Miroslav Filipovic, journaliste serbe. Revue de la Ligue des droits de l'homme. Hommes \& Libertés. n. 112, Janvier/Février 2001, pp. 18 19.

${ }^{621}$ O TPII foi criado pela resolução 827 do Conselho de Segurança de 25 de maio de 1993, como reação internacional aos "massacres, expulsões, deslocamentos de população visando à puirificação étnica, em nome da qual os nacionalistas sérvios tentam - primeiro na Croácia e depois na Bósnia-Herzegovina (antes dos acontecimentos de Kosovo de 1998 e 1999) - fazer com que partam de determinadas regiões os habitantes não sérvios"." Cf. BAZELAIRE, Jean-Paul; CRETIN, Thierry. A Justiça Penal Internacional: sua evolução, seu futuro de Nuremberg a Haia. Tradução de Luciana Pinto Venãncio. Barueri: Manole, 2004, p. 51.

${ }^{622}$ Conforme art. 15 do Estatuto do Tribunal Internacional da Ex-Iugoslavia, "Os juizes do Tribunal Internacional adotarão regras de procedimento e recolha de provas para a condução da fase prévia do julgamento, do julgamento e dos recursos, de admissibilidade de provas, de proteção das vítimas e das testemunhas e de outras questões apropriadas".
} 
colheita da prova era flexível e admitiam-se aquelas que, potencialmente, tivessem valor para a busca da verdade. ${ }^{623}$ Assim, o TPII entendia relevante a oitiva de repórteres para testemunhar os fatos e confirmar as notícias divulgadas pelos meios de comunicação.

Embora não se tenha notícia sobre a utilização desse meio de prova no processo contra Milosevic $^{624}$, no caso do julgamento do vice primeiro ministro da Bósnia, Radoslav Brdjanin y Momit Talic, o jornalista, correspondente de guerra, Jonathan Randal, do "The ashington Post", foi chamado a testemunhar acerca da veracidade de uma entrevista feita com Radoslav Brdjanin, ex-dirigente Bósnio, acusado de crimes contra a humanidade. Negou-se a depor sob o argumento de proteção das fontes, além da possibilidade de os jornalistas perderem a credibilidade, sem dizer do perigo que suas vidas poderiam correr. A Câmara de Apelação do TPII, em 11 de dezembro de 2002, revogou a determinação judicial que obrigara o testemunho do jornalista, por ausência de fundamento, uma vez que não havia sido demonstrado um concreto e relevante interesse do depoimento para o processo. ${ }^{625}$ Nessa oportunidade, o Tribunal Internacional entendeu intangível o segredo profissional jornalístico.

O caso Jonathan Randal fez despertar o problema do segredo da fonte de informação jornalística no âmbito internacional. Se repórteres de guerra são cidadãos de Estados distintos, nos quais o segredo profissional é tutelado, ou não, em nível constitucional, qual normativa aplicável para esse meio de prova não é questão que se solucione com tranquilidade.

\footnotetext{
${ }^{623}$ Segundo Marcos Alexandre Coelho Zilli, a flexibilidade do sistema probatório dos tribunais internacionais tem por fim impedir um embate com as normas dos ordenamentos domésticos. Cf. A prova ilícita e o Tribunal Penal Internacional: regras de admissibilidade.Tese apresentada ao curso de Pós-Graduação da Faculdade de Direito da Universidade de São Paulo, área de concentração em Direito Processual, como requisito parcial à obtenção do título de Doutor em Direito. São Paulo: FADUSP, 2006, p. 152.

${ }^{624}$ Sobre o processo de Milosevic ver AMBOS, Kai. El proceso contra Slobodan Milosevic: un balance provisional. Tradução de Rodrigo Aldoney Ramírez. In: Revista Penal, n. 15, España: La Ley, Enero 2005, p.3-7.

${ }^{625}$ FREITAS, Helena de Sousa. Sigilo profissional..., op. cit., p. 117. Cf. a íntegra da decisão disponível em http://www.un.org/icty/Supplement/supp38-e/talic.htm.
} 


\subsubsection{As fontes das notícias sobre a guerra}

A mídia tem acesso ao conhecimento dos fatos referentes aos crimes de guerra, com maior rapidez e facilidade do que os conhecem os agentes de informações, os investigadores do Tribunal Internacional. No entanto, são as fontes oficiais de informação em tempos de guerra, quase as únicas disponíveis. Além dessas, hoje há também os blogs, os sites da internet, os quais contêm diários de guerra, comentários, análise do desenrolar dos acontecimentos, escritos por militares, familiares desses, cidadãos comuns e analistas políticos, que se encontram na zona de conflito. ${ }^{626}$

Essas fontes, em pleno conflito bélico, não possibilitam que os jornalistas correspondentes de guerra as confirmem, selecionem as informações recebidas, verifiquem se são manipuladas ou parciais, sobretudo na hipótese de os repórteres acompanharem o exército aliado, sem que possam observar os acontecimentos do "lado inimigo". Em tempos de guerra, as informações são contraditórias, por vezes censuradas e padecem de credibilidade; "a verdade adota diferentes facetas", conforme o acesso que se tenha à fonte, conforme a intenção desta, em determinado momento político, de informar, ou não. ${ }^{627}$

O trabalho do profissional correspondente de guerra é peculiar pelas condições adversas em que se encontra e, por tal razão, na grande maioria das vezes busca o jornalista divulgar a fonte para dar credibilidade à notícia, já que ela é tão incerta durante a guerra. Quem são os responsáveis pelas atrocidades ocorridas na guerra, todos sabem e, portanto, o que justifica o depoimento do jornalista? É, segundo Louise Arbour, a sacramentalização da verdade diante da Justiça, é o reconhecimento dos fatos conhecidos, perante o Tribunal. ${ }^{628}$ Daí a imprescindibilidade de seu depoimento e de a Justiça ter acesso ao material de trabalho para a busca da verdade no processo penal internacional.

\footnotetext{
${ }^{626} \mathrm{Na}$ recente guerra do Irak, os weblogs, conhecidos como warlogs, warbloggers, firmaram-se como principais fontes de informação, tornando-se uma alternativa aos demais meios de comunicação social. Cf. CAZORLA, Alfredo; CERMELE, Leonardo; D’ALESSANDRO, Mauricio; LACALDE, Jimena; PADILLA, Miguel Mendoza. Las fuentes de información em tiempos de guerra. In: Sala de Prensa. Web para professionales de la comunicacion iberoamericanos. Año VI, n. 71, Septiembre 2004, Vol. 3, pp.15-16. Disponível em http://www.saladeprensa.org/art564.htm. Acessado em 06/10/2011.

627 CAZORLA, Alfredo; CERMELE, Leonardo; D’ALESSANDRO, Mauricio; LACALDE, Jimena; PADILLA, Miguel Mendoza. Las fuentes de información em tiempos de guerra. In: Sala de Prensa. Web para professionales de la comunicacion iberoamericanos. Año VI, n. 71, Septiembre 2004, Vol. 3, p17. Disponível em http://www.saladeprensa.org/art564.htm. Acessado em 06/10/2011.

${ }^{628}$ Cf. O equilíbrio justo...op. cit., p. 186.
} 


\subsubsection{Por uma regulamentação processual internacional do segredo da fonte}

Após a criação dos Tribunais Internacionais, $A d-h o c$, para a ex-Iugoslavia e de Ruanda - esse de 1994, cuja origem decorre da guerra interétnica entre Hutus e Tutsis ${ }^{629}$ surgiu a necessidade de um tribunal permanente para julgar crimes contra a humanidade. Foi criado, então, o Tribunal Penal Internacional, por acordo celebrado entre inúmeros Estados, em Roma, no ano de 1998.

O sistema de normas processuais do Tribunal da ex-Iugolávia foi o adotado, com modificações, pelo Estatuto de Roma assim como o Rules of Procedure and Evidance hoje aplicado no Tribunal Penal Internacional. ${ }^{630}$ No que diz respeito à prova, além da regulamentação no Estatuto de Roma, vem pormenorizada nas "Regras de Procedimento e Prova" ${ }^{631}$ e, só no caso de conflito entre normas prevalecem aquelas do Estatuto da Corte, as quais não devem afetar as regras aplicáveis nos sistemas processuais nacionais.

$\mathrm{O}$ art. 69 do Estatuto da Corte, o qual trata da prova, prevê que "o Tribunal respeitará e atenderá aos privilégios de confidencialidade estabelecidos no Regulamento Processual'. No procedimento junto ao Tribunal, portanto, as comunicações na relação profissional entre advogado e cliente, entre os acusados e seus médicos, psiquiatras e sacerdotes não podem ser divulgadas. São consideradas informações privilegiadas, conforme previsto no art. 73 do Regulamento de Processo e Prova do Tribunal Penal

${ }^{629}$ O Tribunal Penal Internacional para Rwanda foi criado pela Resolução 955 de 8 de novembro de 1994, pelo Conselho de Segurança da Organização das Nações Unidas, para julgar crimes de genocídio e contra a humanidade. Sobre a origem dos conflitos e da violência contra as pessoas ocorridos em Rwanda, bem como a criação do Tribunal "ad hoc", cf. BEMBA, Joseph. Justice internacionale et liberté d'expression. Les médias face aux crimes internationaux. Paris: L’Harmattan, 2008, pp. 17-46.

${ }^{630}$ No estudo da evolução do processo penal internacional, Wladimir Brito ressalta a modificação marcante e inovadora das regras procedimentais, as quais deixaram de ser produto de uma criação "legislativa judicial" e se originam da vontade dos Estados, reunidos em Assembléia. Trata-se, segundo o autor, de "um mecanismo estabilizador das regras de processo que a natureza permanente do Tribunal impõe e que os Estados cedo se aperceberam da sua necessidade para credibilizar o Tribunal". Cf. Processo Penal Internacional. In: MONTE, Mário Ferreira; CALHEIROS, Maria Clara; MONTEIRO, Fernando Conde; LOUREIRO, Flávia Noversa (Coords.). Que futuro para o direito processual penal? Simpósio em Homenagem a Jorge de Figueiredo Dias, por ocasião dos 20 anos do Código de Processo Penal Português. Coimbra: Coimbra Editora, 2009, p. 241.

${ }^{631}$ Prevê o art. 51 do Estatuto de Roma as condições de criação, vigência e alterações Regulamento processual. 
Internacional. ${ }^{632} \mathrm{Nada}$ há regulamentado, no entanto, quanto ao segredo profissional do jornalista.

Se houver necessidade de divulgar as fontes e materiais de trabalho jornalístico, no contexto internacional, algumas questões não podem ser esquecidas, como a exposição da vida de civis informantes e dos próprios jornalistas, "a um risco inaceitável"633, além de se considerar a legislação sobre o segredo profissional de cada Estado de origem dos jornalistas.

Não se avizinha uma solução definitiva. Importante anotar, no entanto, que no Tribunal Penal Internacional existe a possibilidade de a testemunha prestar declarações de maneira confidencial, sem que essas sejam disponibilizadas ao conhecimento público ou a qualquer Estado. As regras de procedimento e provas que dispõem sobre essa garantia de confidencialidade (74 e respectivos itens), referem-se às declarações que poderão incriminar a testemunha. O direito ao silêncio, in casu, poderá ser restringido (regra 74 (2)) sob a garantia de reserva das suas declarações as quais, inclusive, não poderão ser usadas contra si, em qualquer processo subseqüente perante o Tribunal (regra 74 (3) (c) ). ${ }^{634}$

É possível admitir-se que tais regras possam ser aplicadas pela Corte Internacional na hipótese de um jornalista, correspondente de guerra, ser chamado a prestar declarações. Como qualquer pessoa, poderá ser obrigado a testemunhar, sob pena de multa (regra 65 (2), 171). E, se se recusar sob alegação de direito a não auto incriminação, a garantia da confidencialidade poderá ser-lhe oferecida.

${ }^{632}$ Cf. COLOMER, Juan Luis Gómez; MONTOLIU, Ana Beltrán. La regulación de la prueba en el processo penal ante la Corte Penal Internacional. COLOMER, Juan Luis Gómes; CUSSAC, José Luis González; LLORÉNS, Jorge Cardona (Coords.). La Corte Penal Internacional (Un estudio interdisciplinar). Valencia: Tirant lo blanch, 2003, pp. 333-334. Esclarecem os autores que a prova não está regulada somente no Estatuto de Roma da Corte Penal Internacional, mas também nas Regras de Procedimento e Prova que se fundamenta no art. 51 do Estatuto. Essas regras surgiram de um informe da Quinta Sessão para a Comissão Preparatória da Corte penal Internacional, na sede das Nações Unidas e foram aprovadas em 02 de novembro de 2000 ( Cf. pp. 325-326).

${ }^{633}$ ARBOUR, Louise. O equilibrio justo...op. cit., p. 184.

634 Cf. AMBOS, Kai. O direito à não-auto-incriminação de testemunhas perante o Tribunal Penal Internacional. Tradução de Karina Pawlowsky e Elouise Mirian Santos. In: Revista de Estudos Criminais. Ano 2, n. 8. Rio Grande do Sul: Pontifícia Universidade Católica. 2003, p. 68. 
Louise Arbour entende que não se fará justiça sem a contribuição da imprensa. ${ }^{635}$ De qualquer modo, a magnitude dos crimes julgados pelo TPI e, sobretudo, as razões de seus cometimentos, exigem que a punição dos responsáveis se efetive e possa servir, se não para solucionar os conflitos sociais, ao menos como um dos elementos integrantes do processo internacional de valorização dos direitos do homem, do ser humano. $^{636}$

Primeiramente, é preciso que os Estados-parte implementem o Estatuto de Roma, elaborem uma adequada legislação processual aplicável "a todas as formas de cooperação especificadas na presente parte" (art. 88 do Estatuto). Há, portanto, a necessidade de se estabelecer um "regime processual de cooperação com a CPI". 637

O segredo profissional do jornalista deve ser entendido numa esfera de eficácia internacional. Pensamos que, se no âmbito da evolução do processo penal internacional foi se desenvolvendo, progressivamente, um "standard processual internacional mínimo" ${ }^{638}$, o direito de confidencialidade da fonte do jornalista, derivado de normas dos Tratados e Convenções sobre Direitos Humanos, há que ter seu conteúdo construído e interpretado numa ótica comum de um international due process of law, no qual sejam respeitados os direitos e garantias processuais ${ }^{639}$, sem prejuízo de que cada Estado, individualmente, estabeleça a própria e adequada tutela legislativa daquele direito. ${ }^{640}$

${ }_{635}^{635}$ ARBOUR, Louise. O equilibrio justo... cit., p. 186.

${ }^{636}$ ZILLI, Marcos Alexandre. Bem-aventurados os sedentos de justiça...In: PIOVESAN, Flávia; SOARES, Inês Virgínia Prado (Coords). Direito ao desenvolvimento. Belo Horizonte: Fórum, 2010, pp. 599-600.

${ }^{637}$ AMBOS, Kai. Implementação do Estatuto de Roma na legislação nacional. In: AMBOS, Kai; MALARINO, Ezequiel. Persecução penal internacional na América Latina e Espanha. Versão brasileira a partir do original em espanhol: Persecución penal internacional em America Latina y España. Tradução e organização: IBCCRIM. São Paulo: IBCCRIM, 2003. p. 28.

${ }_{638}^{63}$ BRITO, Wladimir. Processo penal... cit., p. 246.

${ }^{639}$ Segundo Juan Luis Gómez Colomer, Na Conferência de Roma concluiu-se que o aspecto processual era questão de extrema relevância, da qual dependeria o êxito ou o fracasso do futuro Tribunal. E isso significaria, em grande medida, o respeito aos direitos e garantias processuais, à necessidade de um justo e devido processo. Cf. La investigación del crimen en el proceso penal ante el Tribunal Penal Internacional. In: Revista Penal, n. 12, España: La Ley, Julio 2003, p.73.

${ }^{640}$ Nesse sentido: VENTURA, Adrian. Libertad...op. cit., p. 271; BRITO, Wladimir. Processo penal.... cit., p. 246. 


\subsection{A questão do sigilo da fonte na internet.}

Com os avanços tecnológicos surgiram meios alternativos de se fazer jornalismo e hoje, os sites e $b \operatorname{logs}{ }^{641}$ disponíveis na internet, são considerados verdadeiros meios de comunicação social de massa, fenômenos populares de visitas por usuários da Word Wide Web, ou internet

Como mídias, os bloggers ${ }^{642}$ ou os responsáveis por determinados sites poderiam, se testemunhas no processo penal, negarem-se a identificar a fonte de uma informação, amparando-se na confidencialidade que protege o profissional do jornalismo?

O tema começa a ser debatido e a adequação de conceitos na era digital se impõe. Na VI Conferência Ministerial Europeia do Conselho da Europa Sobre a Política do Mass $M_{e d i a}{ }^{643}$, sugeriu-se a análise das "implicações da divulgação online de informação por indivíduos ou outras fontes que podem não estar vinculados à ética profissional ou aos códigos deontológicos dos jornalistas".

Em 2006, no caso Apple vs. Does a questão foi discutida. Informações confidenciais da empresa Apple foram publicadas em alguns sites da web. Em ação judicial, a empresa pediu que os autores dos sítios revelassem a origem das informações divulgadas, o que foi recusado por eles, ampararando-se no amplo direito à confidencialidade das fontes. O argumento foi aceito pelo Tribunal Superior da Califórnia o qual entendeu que se tratava de jornalistas on line merecedores da mesma proteção que é dada aos profissionais tradicionais. E na sentença fez-se constar que "a lei visa à proteção da recolha e disseminação de informação e isso foi o que fizeram os titulares dos blogs". 644

\footnotetext{
641 Fernando E. Shina diz que "um blog é um sitio web, criado por qualquer usuário, no qual se pode compilar artigos ou textos pertencentes a um ou vários autores. (...) Normalmente os leitores de um blog escrevem um comentário acerca de um artigo que tenham lido. Desta forma se produz um debate entre o autor do artigo e seus leitores. O conteúdo de cada blog é diverso: podem ser pessoais, jornalísticos, políticos, sobre economia, sobre esportes etc. Indubitavelmete o blog contém muitas das características de um jornal diário tradicional na medida em que reúne informação, a seleciona e a edita”. Cf. La libertad de expresión y otros derechos personalísimos. Buenos Aires: Editorial Universidad, 2009, p. 165.

${ }^{642}$ Bloggers são assim denominados os autores de blogs na internet.

${ }^{643}$ Expresso na Declaração sobre a Política dos Media para Amanhã (15 e 16 de Junho de 2000, Cracóvia, Polônia). Cf. FREITAS, Helena de Sousa. Sigilo...cit., p. 124.

${ }^{644}$ SHINA, Fernando E. La libertad de expresión... cit., p. 167.
} 
Além do mais, esses sítios apresentam características suficientes para serem considerados meios de imprensa e, como tais, devem ser tutelados com as mesmas normas desses.

Outras decisões encontradas na jurisprudência internacional dizem respeito à tutela da privacidade dos cidadãos na denominada "sociedade eletrônica" ${ }^{645}$. Assim, no caso Cahill vs. Doe a Suprema Corte de Delaware, em outubro de 2005, decidiu que um provedor de internet deveria revelar a identidade de um usuário acusado de cometer delito de difamação, pois, na hipótese, não prevalecia a alegada ofensa ao direito de expressão e, tampouco, o argumento de que tem a obrigação, frente aos clientes, de manter a confidencialidade de fontes anônimas. ${ }^{646}$

O jornalismo online é uma realidade em desenvolvimento e produz efeitos na prática jurídica, sobretudo como fonte de prova.

Se a informação de um blog ou site for admitida como prova no processo penal, parece-nos que a tutela constitucional do sigilo da fonte deverá estender-se aos gestores do espaço web, tão somente se se entender que estão no exercício, pelo meio eletrônico, da profissão de jornalista, pois qualquer pessoa pode ser um blogger, sem que seja um profissional da mídia.

$\mathrm{Na}$ hipótese de se admitir como prova o material contido na internet, ou o testemunho do provedor do site ou gestor do blog, o valor probatório deverá ser estimado pelo julgador. É muito preocupante a questão da credibilidade da informação contida na web, principalmente em locais "personalizados", onde o anonimato é regra, inclusive na forma de "identidade falsa".

Portanto, parece-nos que a admissibilidade e valoração da informação contida na internet, se anônima e sem indicação da fonte, não seja lícita, pois se trata, apenas, de um "rumor", sem consistência, sem a possibilidade de as partes contraditarem, ofendendo,

${ }^{645}$ PAGALLO, Ugo. La tutela della privacy negli Stati Uniti d'America e in Europa: modelli giuridici a confronto. Milano: Giuffrè, 2008, p. 26.

${ }^{646}$ Cf. SHINA, Fernando E. La libertad de expresión... cit., p. 174. O autor menciona, também, o caso Kenneth M Zeran vs. America Online, Inc. Cf. p. 180 e seguintes. 
assim, direito processual constitucional. É prova ilícita, inidônea e insuscetível de produzir efeitos no processo penal.

\subsection{O sigilo da fonte como regra de direito fundamental: conseqüências da opção do constituinte brasileiro.}

Já dissemos que o sigilo da fonte para o exercício do trabalho profissional do jornalista está tutelado na Constituição Federal de 1988 por meio de uma regra, e essa confere concreção ao princípio da liberdade de informação. ${ }^{647}$

Dessa afirmação decorrem algumas consequências jurídicas na atividade probatória do processo penal. Duas assertivas se impõem. A primeira, é que o testemunho do jornalista e o material por ele utilizado para elaborar a notícia, como provas, poderão exercer no magistrado uma função persuasiva,${ }^{648}$ compondo o acervo de elementos que permitirão uma reconstrução, ainda que parcial, dos fatos ocorridos. A segunda, diz respeito à informação sobre a origem da fonte: se necessária ao exercício profissional, poderá ser mantida sob sigilo constituindo, portanto, um verdadeiro limite para o acertamento dos fatos.

Tratando-se de uma regra que não se destina ao processo penal, mas pode ser invocada pelo jornalista quando testemunha, admitindo-se que é um limite constitucional à atividade probatória na persecução dos crimes, não haveria meio de superá-la em determinados casos concretos?

A doutrina diz que o sigilo da fonte "não pode ser rompido nem mesmo em face da justiça penal" ${ }^{649}$, da lei ou do Poder Público, pois é absoluto ${ }^{650}$. Mas, e se a fonte, cuja

${ }^{647}$ Cap. I, item 4.2.2

${ }^{648}$ LOPES JR., Aury; DI GESU, Cristina Carla. Falsas memórias e prova testemunhal no processo penal: em busca da redução de danos. In: Revista de Estudos Criminais. Rio Grande do Sul: PUC, Ano VII, n. 25, 2007, p 60.

${ }^{649}$ HUNGRIA, Nelson. A disciplina jurídica... cit., p. 464.

${ }^{650}$ BASTOS, Celso Ribeiro. Comentários à Constituição... cit., 1989, p. 82. No mesmo sentido, porém, admitindo que a exceção possa ser feita por lei: CARVALHO, Luis Gustavo Grandinetti Castanho de. Liberdade de informação...cit., p. 79; GONZAGA, João Bernardino. Violação de segredo...cit., p. 127; BARRETO, Carlos Roberto. Sigilo da fonte. Disponível em http://jus2.uol.com.br/doutrina/texto.asp?id=7176. Acessado em 08/03/2010. Em sentido contrário: 
confidencialidade vem resguardada pelo jornalista, trouxer prova decisiva para inocentar alguém que está sendo acusado de crime, ou puder desvendar um delito de seqüestro em andamento?

\subsubsection{Revelar ou não a fonte: um dever ético?}

O segredo profissional do jornalista tem implicações morais. Ao lado de um direito constitucional de não revelar a fonte há um dever moral, e não jurídico, de garantir a confidencialidade do informante. É um dever ético ${ }^{651}$ do profissional da comunicação diante daquele que lhe proporcionou a informação e é também uma proteção da fonte de não ter sua identidade revelada. ${ }^{652}$

Existe o temor dos profissionais da comunicação de não mais poderem contar com as fontes para exercer a direito de se informarem para informar, perdendo a credibilidade profissional, se o anonimato não for mantido.

Porém, diante de uma situação onde a vida ou a liberdade de uma pessoa depende da revelação da identidade da fonte, parece-nos que há aqui um dever moral do jornalista de tornar pública a origem da informação, rompendo o compromisso de manutenção da confidencialidade, anteriormente firmado.

FERREIRA FILHO, Manoel Gonçalves. Comentários à Constituição brasileira de 1988. $2^{\mathrm{a}}$ ed., v.I, São Paulo: Saraiva, 1997, p. 39; FROTA, Hidemberg Alves da. A quebra do sigilo das fontes jornalísticas pelo Poder Judiciário. In: Revista Jurídica do Ministério Público Catarinense, n. 8, v. 4, jan./abr. 2006, p. 146. Para esse autor, "cumpre ter presente a eventualidade de se pleitear, perante o Poder Judiciário, a quebra do sigilo das fontes jornalísticas, risco que tende a aumentar à medida que o crime organizado se espraia pelo esgarçado tecido social e o Estado cada vez mais é instado pela opinião pública a executar medidas enérgicas contra crescente violência e criminalidade. Deve o magistrado perscrutar de modo criterioso se existe, dentre as medidas disponíveis ao poder Público e adequadas à respectiva finalidade legal, providência estatal igualmente apropriada e, ao mesmo tempo, menos ofensiva ao direito à informação jornalística". Cf. p. 146.

${ }^{651}$ Sobre a questão da ética no jornalismo ver: BUCCI, Eugênio. Sobre Ética e Imprensa. São Paulo: Companhia das Letras, 2000.

${ }^{652}$ PRADERA, Javier. La extraña pareja...cit., p. 38. 
O Caso Cohen v. Cowles Media Co. (1991) ilustra a situação na qual o jornalista e o editor revelaram a fonte, não obstante a promessa de confidencialidade, pois eles entenderam fundamental para a qualidade e credibilidade da notícia. ${ }^{653}$

Com efeito, diante de uma situação extrema, a credibilidade profissional e social do jornalista pode ser demonstrada por sua atitude de revelar a fonte quando era "o único meio para evitar um dano grave e iminente às pessoas". ${ }^{654}$

Essa conduta profissional se amolda ao Código de Ética dos Jornalistas Brasileiros, o qual prevê o resguardo ao sigilo da fonte como um direito ${ }^{655}$ e a defesa dos direitos dos cidadãos como um dever. O jornalista, também, não pode valer-se de sua profissão para incitar a violência e o crime ${ }^{656}$. Logo, cabe a ele avaliar, de acordo com sua consciência, se o direito ao sigilo que pretende exercer não estaria beneficiando, indiretamente, o autor de um delito em andamento e, ao mesmo tempo, colocando em risco a vida de um ser humano.

\subsubsection{A impossibilidade de aplicação do princípio da proporcionalidade}

Sob o aspecto jurídico, as normas-regras não admitem a dimensão do peso ou importância ${ }^{657} \mathrm{~A}$ valoração, o balanceamento entre os direitos ao sigilo e à liberdade ou à vida, integra o campo dos princípios e não da norma-regra da qual estamos tratando. Logo, nem mesmo quando está em jogo a inocência de um acusado, é possível compelir um jornalista a divulgar a fonte, utilizando-se o juiz do princípio da ponderação de valores.

Ao juiz, no processo penal, é defeso aplicar o princípio da proporcionalidade através do qual seria balanceado o direito à prova do acusado e o direito do jornalista ao

\footnotetext{
${ }^{653}$ Cohen v. Cowles Media Co, 501 U.S. 663, 1991. Nesse caso citado por Adrián Ventura, a Suprema Corte Americana, por maioria de votos entendeu que o rompimento do "contrato de confidencialidade" da fonte não encontrava proteção na Primeira Emenda. Portanto, o repórter e o editor deveriam responder a ação civil proposta pelo informante que teve seu nome revelado na notícia. Cf. Libertad... cit., p. 199.

${ }^{654}$ PRADERA, Javier. La extraña pareja ... cit., p. 39.

${ }^{655}$ Capítulo II, artigo $5^{\circ}$.

${ }^{656}$ Capítulo II, artigo $7^{\circ}$, inciso V.

${ }^{657}$ GRAU, Eros Roberto. Ensaio e discurso... cit., p. 174.
} 
sigilo da fonte. Ou se aplica a regra do segredo jornalístico, ou não se aplica ao caso concreto em que não há subsunção à norma.

No entanto, verifica-se que o legislador constituinte cingiu o direito à confidencialidade da fonte ao profissional da comunicação, tão somente quando fosse "necessário ao exercício profissional". Portanto, o segredo da fonte é regra limitada por condição imposta pela própria Carta Magna, no artigo $5^{\circ}$, inciso XIV.

Assim sendo, surge a possibilidade de interpretação judicial dessa regra, ou seja, de revelar seu conteúdo, seu significado para saber se ela incidirá, ou não, ao caso concreto. ${ }^{658}$

A norma que assegura o sigilo, por conseguinte, não se aplica quando a informação não for divulgada por um veículo de comunicação social ou por pessoa que não exerce a atividade jornalística como profissão.

Também, em princípio, parece-nos que a regra não se subsume à situação daquele jornalista que se utiliza do direito de não declinar a fonte da informação divulgada, apesar da anuência do informante em indicar seu nome. Embora nessa hipótese o profissional também não esteja obrigado a declinar a fonte, apesar de ter recebido a informação "on the record" ${ }^{659}$ deve ser verificado, em situações excepcionais e fixadas em lei, se está preenchido o requisito normativo da necessidade da manutenção do sigilo para o exercício profissional.

Ora, se o segredo é tutelado para instrumentalizar o mais amplo direito de liberdade de informar, pois sem ele o fluxo de notícias seria prejudicado; se a não divulgação da fonte é a necessidade de manter a relação de confiança com aquele que informou, um dos pressupostos para a configuração do direito ao segredo previsto no artigo $5^{\circ}$, XIV, parece não estar configurado. ${ }^{660}$

Mas a questão não se soluciona tranquilamente. Pode ocorrer que o jornalista, não obstante esteja desobrigado pelo informante da reserva de sua identidade, entenda que o

\footnotetext{
${ }^{658}$ BARROSO, Luís Roberto. Interpretação e aplicação...cit., p. 97.

${ }^{659}$ Nesse sentido já afirmamos no Cap. V, item 3.2.2.

${ }^{660}$ Nesse sentido, FERNANDEZ ENTRALGO, Jesús. In: La clausula de conciencia y el secreto profesional de los periodistas. Madrid: Centro de Estudios Constitucionales, 1994, p. 58.
} 
levantamento do sigilo poderá prejudicar terceiros, ou até mesmo a vítima. Caberá ao profissional avaliar e justificar a necessidade da manutenção do segredo para o exercício do seu trabalho.

Neste ponto, como garantia do direito ao sigilo constitucional, pensamos que a necessidade para o exercício da profissão jornalística deva ser regulamentada por lei, em hipóteses específicas, desde que não haja dispositivo que constitua embaraço à plena liberdade de informação jornalística em qualquer veículo de comunicação social, "observado o disposto no art. 5, IV, V, , III e I" (art. 220, "caput" e 1 da CF $88){ }^{661}$.

Por um lado, o Poder Judiciário deve contar com critérios objetivos legais para a interpretação e subsunção da norma ao caso concreto. Os significados de necessidade e profissão jornalística, a nosso ver, poderiam ser ampliados de tal maneira pelo julgador se a interpretação da regra constitucional restar tão somente subjetiva, sem balizas de escolhas possíveis, que acabaria por esvaziar o conteúdo essencial do direito fundamental ao sigilo.

Sob outro prisma, o segredo necessário para o trabalho não pode ser invocado pelo jornalista, sem qualquer justificativa dentro de critérios legais, no caso de a fonte concordar em ser identificada, porque estão envolvidos na informação interesses públicos ou privados de vital importância. A reivindicada transparência do Poder, por meio da informação pela mídia, pressupondo o anonimato da fonte, também se legitima no direito dos cidadãos, destinatários das notícias, de conhecerem os motivos da não divulgação da identidade do informante. A visibilidade do Poder não admite que as informações "em plenitude e de máxima qualidade" ${ }^{662}$ que sustentam a democracia, originem-se de uma

${ }^{661}$ Medida Cautelar em Arguição de Descumprimento de Preceito Fundamental 130-7, Distrito Federal, voto do Ministro Gilmar Mendes; O Ministro Carlos de Britto, na ADPF 130-MC, manifestou-se contrariamente à existência uma lei de imprensa brasileira, entendendo ser essa um regramento tão amplo, uma "lei orgânica", incompatível com o texto da Constituição Federal. Mas, esclarece que, "topicamente, nas diversas passagens do capítulo constitucional devotado à comunicação social, há espaço, sim, para a legiferação, mas sempre por um modo tópico, pontual, monotemático. (...). Não é excluir de conformação legislativa todo e qualquer tema atinente à comunicação das idéias, à liberdade de expressão.”

${ }^{662}$ Cf. voto do Ministrro Carlos de Britto na Medida Cautelar em Arguição de Descumprimento de Preceito Fundamental 130-7, Distrito Federal. 
imprensa que se constitua em uma grandiosa "caixa preta" ${ }^{\text {"663 }}$. Portanto, se a fonte autoriza a quebra do anonimato, se estão em jogo a vida, a inocência e a liberdade do acusado, não se pode deixar, exclusivamente, a critério do profissional, o entendimento do significado do que seja necessário ao trabalho.

A norma-regra constitucional do sigilo da fonte não nos permite concluir com a doutrina $^{664}$ que, na hipótese da anuência do informante, na sua identificação, haja um autêntico dever legal de depor, prevalecendo o valor da administração da Justiça sobre a tutela do segredo jornalístico. Não há lei que determine a obrigação de revelar a origem da informação, em nenhuma circunstância.

Entendemos, primeiramente, que uma regulamentação legislativa processual, até mesmo nos moldes dos Códigos de Processo Penal Português e Italiano, ${ }^{665}$ restringiria o segredo jornalístico e, por consequência, atingiria o conteúdo da liberdade de informação. Ora, se a Constituição estabeleceu uma norma com estrutura de regra, que visa a resguardar a confidencialidade da fonte, o legislador infraconstitucional não está legitimado a restringir esse direito o qual não foi destinado ao processo penal.

Não havendo a possibilidade, nem mesmo indiretamente, de intervenções legislativas processuais que se justifiquem constitucionalmente, sem que o direito posto seja violado, também não pode exercer qualquer papel, num contexto de conflito entre o sigilo do jornalista e o direito à prova para a defesa do acusado, o princípio da proporcionalidade, admissível em relação aos demais segredos profissionais tutelados por lei ordinária.

Diante da regulamentação constitucional do sigilo da fonte, qual a única solução possível para o caso de a identificação do informante pelo jornalista for a única prova da defesa, passível de inocentar o acusado? Em primeiro lugar, parece-nos difícil imaginar, hipoteticamente, que a defesa possua fundamentos suficientes para concluir que o informante da mídia tenha provas decisivas da inocência do acusado no processo penal e

${ }^{663}$ CLEINMAN, Betch. Litígios de estrondo entre os $3+1$ Poderes da República. In: Cidadania e Justiça. Ano 3, n. 6, $1^{\circ}$ semestre de 1999, p. 29.

${ }^{664}$ Cf. SOUZA, Diego Fajardo Maranha Leão. Sigilo profissional...op. cit., p. 149. No mesmo sentido: LUCA, Javier Augusto de. El secreto...cit., pp. 116-117.

${ }^{665}$ Itens 1 e 2 do presente capítulo. 
não haja outras maneiras, no âmbito do Poder investigatório do Estado, de identificá-la sem violar norma de estatura constitucional.

Porém, se todos os esforços forem envidados nesse sentido e a identidade da fonte continuar sendo "prova decisiva" para inocentar a pessoa que está respondendo a processo criminal, a alternativa para compor os valores em conflito é preservar a regra constitucional do sigilo jornalístico e absolver o acusado por insuficiência de provas, como conseqüência do princípio in dubio pro reo. No caso, a declaração de inocência do acusado, sustentada na dúvida gerada pela precariedade de provas, não é mais prejudicial ao réu que poderia, com a identificação do informante pelo jornalista, ter comprovação plena da sua não responsabilidade pelo crime. Afirma Antonio Magalhães Gomes Filho, que contraria o preceito constitucional da presunção de inocência "qualquer diferenciação de tratamento que se estabeleça entre o réu que foi absolvido plenamente e aquele que o foi por precariedade de provas", 666

\subsubsection{A jurisprudência brasileira}

No Brasil não se verifica um desenvolvimento jurisprudencial sobre o sigilo da fonte. Poucos casos sobre a polêmica questão da quebra do segredo profissional do jornalista foram julgados pelos nossos tribunais. Não obstante, talvez seja possível, tendo como base as decisões já proferidas, delinear o rumo da jurisprudência brasileira.

Anteriormente à Constituição de 1988, o Tribunal de Alçada Criminal de São Paulo, fundamentado na Lei de Imprensa, decidiu que o jornalista não pode ser compelido a indicar sua fonte de informação e, seu silêncio, não lhe acarreta sanções penais ou civis. ${ }^{667}$ Já em 1996, decisão do Ministro Celso de Mello do Supremo Tribunal Federal, excluiu qualquer exceção à inviolabilidade do sigilo das fontes jornalísticas. Para o Ministro, a referência constitucional à confidencialidade da fonte de informação limita a atividade do Poder Público e impede a aplicação de qualquer sanção administrativa, civil

${ }^{666}$ Cf. Presunção de inocência e prisão cautelar. São Paulo: Saraiva, 1991, p. 41.

${ }^{667}$ Apelação n. 247.737, $1^{\text {a }}$ Câm., v.u., j. 20.10.1980, Relator Marcondes de Moura, JTACrSP 64/316. 
ou penal ao profissional da mídia. ${ }^{668} \mathrm{O}$ Tribunal Regional Federal da $3^{\mathrm{a}}$ Região decidiu que "Configura manifesto constrangimento ilegal o ato de autoridade que determina o indiciamento de jornalista em inquérito policial caso não quebre o sigilo de suas fontes de informação jornalística", 669

O tema do levantamento do sigilo da fonte foi discutido, com maior amplitude, no caso Marka Fonte Cindam, no qual o Ministério Público Federal, durante investigação de corrupção envolvendo servidores do Banco Central e dirigentes de bancos privados, pediu a quebra do sigilo telefônico de repórteres da revista "Veja" e do jornal "O Estado de São Paulo", para se chegar às pessoas que forneciam informações sobre a "engrenagem do esquema" que gerou grande prejuízo aos cofres públicos. ${ }^{670} \mathrm{O}$ pedido foi indeferido pela Justiça Federal de $1^{\mathrm{a}}$ instância. ${ }^{671}$

${ }^{668}$ Trata-se de caso no qual se investigava contravenção de "Jogo do Bicho", cuja indiciada era a Deputada Cidinha Campos. Um jornalista que manteve contato com ela, reportou o episódio concernente à "Lista do Bicho" e teria sido compelido a indicar a fonte de informação. O Ministro foi taxativo ao concluir que a investigação penal não pode atingir o sigilo dafonte: "Em suma: a proteção constitucional que confere ao jornalista o direito de não proceder à disclosure da fonte de informação ou de não revelar a pessoa de seu informante desautoriza qualquer medida tendente a pressionar ou constranger o profissional da Imprensa a indicar a origem das informações a que teve acesso, eis que - não custa insistir - os jornalistas, em tema de sigilo da fonte, não se expõem ao poder de indagação do estado ou de seus agentes e não podem sofrer, por isso mesmo, em função do exercício dessa legítima prerrogativa constitucional, a imposição de qualquer sanção penal, civil ou administrativa. Estas considerações - que são feitas em função da natureza das diligências investigatórias solicitadas pelo Ministério Público Federal no presente inquérito - têm a única finalidade de indicar, de maneira bastante precisa, as áreas que se acham pró-excluídas do âmbito da investigação penal, seja por efeito de determinação legal (Lei $n^{\circ}$ 5.250/67, art. 71), seja como consequiência de expressa imposição constitucional”. Cf. Inquérito 870/RJ, Relator: Min. Celso de Mello, j. 08/04/1996, DJU 15/04/1996, pp. 11461.

${ }^{669}$ RHC, Proc. 1999. 61.81.002202-0/SP, 2a Turma, v.u., j. 7/12/1999, Rel. Juiz Aricê Amaral, DJU 22/03/2000, RTRF 44/255.

${ }^{670}$ O Procurador da República, Bruno Acioli, investigava o caso e objetivou descobrir as fontes sigilosas dos jornalistas, por meio da análise das suas chamadas telefônicas, pois entendia possuir fortes indícios de que integrante do "esquema criminoso" repassava as informações para a mídia. Para ele, as investigações só teriam êxito com a quebra do sigilo telefônico dos jornalistas. Disse: "No caso vertente, o que ocorria era o seguinte: informações privilegiadas do governo vazavam para o mercado financeiro através de insiders (informantes) do Bacen (Banco Central), conforme matéria publicada por uma revista semanal, fundada em informações e documentos repassados por um banqueiro que conhecia as engrenagens do esquema ". Cf. Folha de São Paulo, 30/12/2005, p. A 12; Segundo Bruno Caiado de Acioli, o "Poder Público não pode ficar privado da alternativa de valer-se dos meios probatórios legais e constitucionais existentes, com o fito de obter o dado recusado pelo jornalista, sob a alegação de sigilo de fonte. Note-se que uma coisa é obrigar o profissional a identificar a fonte a fonte ou então puni-lo pela recusa em revelar o segredo; outra, muito diferente, é buscar desvendar o segredo; via afastamento excepcional do sigilo de dados telefônicos do jornalista. A primeira alternativa é abusiva, ao passo que a segnda não". Cf. O princípio do sigilo da fonte e as suas limitações. In: Revista Jurídica Consulex, Ano X, nº 217, 31 de janeiro/2006. p. 28.

${ }^{671}$ Sobre o Caso Marka Fonte Cindam ver descrição detalhada in: PINHO, Maria Cecília Labate Maiolini Rebello. O sigilo da fonte como garantia da liberdade de informação jornalística. Dissertação de Mestrado apresentada na Faculdade de Direito da Universidade de São Paulo, 2007, pp. 84-85. 
As poucas decisões mencionadas demonstram a tendência da jurisprudência brasileira em privilegiar a aplicação da regra constitucional do sigilo da fonte, sem restrições. E o Supremo Tribunal Federal, na decisão da Medida Cautelar em Arguição de Descumprimento de Preceito Fundamental 130-7, na assertiva de que a Constituição da República revelou "hostilidade" a qualquer prática de restrição ou interferência do Estado na liberdade de expresão e informação, indiretamente revelou um caminho a seguir, de ampla tutela do segredo profissional do jornalista. ${ }^{672}$

\subsubsection{A responsabilidade do jornalista pelos abusos na informação}

Pelos abusos do direito de informar, pelos excessos contidos nas publicações de notícias que produzam danos a qualquer pessoa, o jornalista poderá ser responsabilizado penal e civilmente.

Primeiramente, é preciso esclarecer que o profissional da mídia, porque tem um direito e não dever de sigilo, não incide no crime de violação de segredo profissional, tipificado no artigo 154 do Código Penal. A obrigação legal de reserva, como já dissemos, alcança somente o "confidente necessário", não sendo o caso do jornalista que, no exercício de seu mister, recebe voluntariamente a informação da pessoa que pretende manter-se no anonimato.

Há posicionamento doutrinário no sentido de que o jornalista tem o dever de não divulgar a fonte, e o descumprimento poderá incidir no crime do artigo 154 do Código Penal. Desse possicionamento resulta que, se for acusado em processo penal, a revelação da fonte, se necessária para sua defesa, justifica-se pelo estado de necessidade e, portanto, a antijuridicidade será excluída. ${ }^{673}$

Nesse ponto surge o problema do segredo profissional diante da exceptio veritatis em processo crime de calúnia. Se o jornalista é obrigado a provar a veracidade dos fatos publicados e se não puder fazê-lo sem identificar a fonte, a alegação do direito

\footnotetext{
${ }^{672}$ Cf. voto do Ministro Celso de Mello.

${ }^{673}$ CARVALHO, Luis Gustavo Grandinetto Castanho de. Liberdade de informação...cit., p. 79.
} 
constitucional ao sigilo não lhe protege, pois sua eficácia não o alcança na condição de acusado, mas tão somente como testemunha. ${ }^{674}$ Logo, se não revelar a fonte, quando imprescindível, a verdade da notícia divulgada não restará provada.

O segredo da fonte não é, necessariamente, ${ }^{675}$ obtido pelo jornalista em função do seu trabalho, mas pode ser a ele solicitado. Manter sob reserva a identidade do informante é um direito, porém, se não for exercido, eventualmente, poderá levá-lo a responder, em razão do que divulgou na imprensa, por crimes contra a honra ou até, por denunciação caluniosa (art. 339 do Código Penal).

Considerando que o jornalista, como testemunha em processos administrativos ou judiciais, não tem a obrigação de revelar a fonte de informação, ${ }^{676}$ não responde por crime de falso testemunho quando se negar ou calar a verdade sobre a identidade do informante. Porém, como esclarece Marc Carrillo, se o jornalista pretende utilizar-se do direito de manter sob reserva a fonte, deve "optar pelo silêncio". Não pode, em juízo, falsear a verdade ou fazer afirmações equivocadas, inexatas, no intuito de encobrir a verdadeira identidade do informante, pois poderá, nessa circunstância, responder por crime de falso testemunho. ${ }^{677}$

O profissional do meio de comunicação também não incide no crime previsto no artigo 330 do Código Penal, se desobedecer à ordem do juiz ou de qualquer outra autoridade para, por exemplo, entregar material de trabalho no qual possa conter dados que revelem a origem da publicação. Aliás, João Bernardino Gonzaga enfatiza que qualquer

${ }^{674}$ CARRILLO, Marc. Cláusula de consciência...cit., p. 432.

${ }^{675}$ Diz Nelson Hungria que "No tocante às confidências orais e sem cunho de necessidade, ficam por conta e risco de quem as faz sem precatar-se contra intrusos e sacos-rotos. Por outro lado, são protegidos unicamente os segredos cuja violação acarrete ou possa acarretar dano a outrem (a quem os confiou ou a terceiros)" Cf. Comentários ...cit., p. 249.

${ }^{676}$ Em decisão do caso Anibal Gomes Ornelas vs. Jornal da Tarde S.A. - O Estado de São Paulo, constou do acórdão do Tribunal de Alçada Criminal de São Paulo: “CRIME DE IMPRENSA - Reportagem gravada Pretendida apreensão da fita em jornal que apenas noticiou a reportagem feita por outro órgão de imprensa Inadmissibilidade - Apelo improvido - 257 - O jornalista ou radialista, nos termos da lei de Imprensa, não pode ser compelido a indicar o nome da infração ou indicar a fonte de sua informação; o seu silêncio não implica imposição de qualquer sanção" (JTACrSP, Apelação n. 247.737 SP, Relator Juiz Marcondes de Moura, j. 20.10.1980, LEX 64/316).

677 Cf. Cláusula de consciencia..., p. 431. No mesmo sentido: ROIG, Rafael de Asís. Secreto profesional...cit., p. 162. 
pessoa que force, obrigue o jornalista a levantar o sigilo da fonte, poderá incidir nas penas do crime de constrangimento ilegal (art. 146 do Código Penal). ${ }^{678}$

Finalmente, se a revelação da identidade causar prejuízo ao informante, o profissional poderá ser responsabilizado civilmente por danos materiais ou morais. É o que dispõe a Constituição brasileira no artigo $5^{\circ}$, incisos V e X e, o Código Civil, nos artigos 186 e 927, não deixa dúvidas sobre a obrigação de indenizar o dano patrimonial ou moral causado a outrem. ${ }^{679}$

A eficácia do direito constitucional ao sigilo, portanto, vai depender da atuação consciente e responsável do jornalista o qual deve privilegiar, sempre quando possível, a publicação da origem da notícia. ${ }^{680} \mathrm{O}$ direito ao anonimato da fonte não significa imunidade absoluta do profissional, mas dele decorre a responsabilidade pela informação publicada. $^{681}$

${ }^{678}$ Cf. Violação de segredo...cit., p. 127.

${ }^{679}$ Dispõe o artigo 186 do Código Civil: "Aquele que, por ação ou omissão voluntária, negligência ou imprudência, violar direito e causar dano a outrem, ainda que exclusivamente moral, comete ato ilícito." E o artigo 927 determina a obrigação de indenizar, nos seguintes termos: "Aquele que, por ato ilícito (arts. $186 \mathrm{e}$ 187), causar dano a outrem, fica obrigado a repará-lo. (...)".

${ }^{680} \mathrm{O}$ Jornal americano Washington Post estabelece aos seus repórteres a obrigatoriedade de revelar as fontes de todas as informações, determinando que essas, se o caso, sejam buscadas em fontes que permitam serem identificadas. Quando a revelação colocar em risco a segurança das fontes, ou houver outro motivo para que o informante mantenha-se anônimo, as razões devem ser justificadas e incluídas na matéria. Cf. GOODWIN, H. Eugene. Procura-se ética no jornalismo. Tradução de Álvaro de Sá. Rio de Janeiro: Editorial Nórdica, 1993, p. 159.

${ }^{681}$ SORIA, Carlos. El labirinto informativo: uma salida ética. Pamplona: Ediciones Universidad de Navarra, 1997, p. 266. 


\section{CONCLUSÕES}

1. A proposição exposta e defendida nesse trabalho é a de que o direito à prova penal, caracterizado pela efetiva possibilidade de as partes poderem, concretamente, agir para influenciarem o convencimento do juiz, encontra verdadeira barreira no sigilo da fonte de informação jornalística. Esse limite no sistema jurídico brasileiro, no qual o direito à manutenção da confidencialidade do informante possui estrutura de regra de direito fundamental, é insuperável, pois não há norma de estatura constitucional que a regulamente ou a restrinja.

Dessa afirmativa decorre que, em nenhuma hipótese, o profissional da mídia, como testemunha, poderá ser compelido a revelar a identidade da fonte, não obstante possa fazêlo, se assim entender. Por consequência, a prova colhida com violação do segredo profissional jornalístico é ilícita, e aquela colhida com a manutenção do anonimato da fonte não terá valor probatório.

O estudo, portanto, abordou a relação da prova penal, como meio de se atingir uma “verdade processual” possível e necessária para a realização do ius puniendi do Estado, em uma sociedade fundada na Democracia que tem, como um dos pilares de sustentação e desenvolvimento, a liberdade de imprensa na sua vertente do direito de informação.

2. Não faremos uma síntese das várias teses defendidas ao longo do trabalho. A proposta, no desfecho da pesquisa, é apresentarmos nosso ponto de vista, o resultado sobre o raciocínio que fizemos a partir do estudo das normas que regulamentam os segredos profissionais no processo penal e aquela especificamente endereçada pelo legislador constituinte de 88 ao profissional dos meios de comunicação.

Procuraremos, assim, pontuar o que de essencial extraímos da reflexão sobre assunto tão complexo, o qual envolve importantes valores tutelados no Estado Democrático de Direito, positivados em textos de categorias normativas distintas constitucional e infraconstitucional. No entanto, no contexto da sociedade midiática contemporânea, não se pode deixar de considerar que tais direitos irão colidir e exigirão do julgador, do legislador e da pessoa titular do direito ao sigilo uma tomada de posição. Da 
afirmativa decorrem nossas posições conclusivas e possíveis soluções para os casos nos quais o direito à prova reclamará sua efetividade, mas encontrará limite na Constituição Federal.

3. Ao final do trabalho, surgiu uma questão cuja resposta pareceu-nos decisiva como pano de fundo do quadro conclusivo: a revelação da identidade da fonte é imprescindível para o acertamento dos fatos no processo penal?

Depois de Watergate, escândalo que culminou com a renúncia do Presidente Richard Nixon, nos Estados Unidos, passou a ser comum que os jornalistas fossem chamados como testemunhas em procedimentos do grand jury. Se se negarem a declarar, poderão incorrer em contempt - desacato ao tribunal - sofrendo sanções civis ou penais. Diante da resistência dos repórteres em divulgar a fonte da informação, como ocorreu com Judith Miller, o que a levou à prisão, os tribunais, no intuito de convencer os profissionais a divulgar a identidade dos informantes, passaram a entender como "fabricadas" as fontes anônimas, chegando a considerarem inexistentes as informações sem origem. No julgamento de I. Lewis Libby, ex-chefe de gabinete do vice-presidente americano, Dick Cheney, condenado por perjúrio e obstrução à justiça, no processo que envolvia vazamento da identidade secreta da agente da CIA, Valerie Plame, das dezenove testemunhas, dez eram jornalistas cujos depoimentos foram decisivos para a condenação. Por muitos anos, a fonte das informações do caso Watergate, pessoa conhecida apenas por "Garganta Profunda" (Deep Throat), não foi identificada. Somente trinta e três anos após os fatos, o próprio informante, W. Mark Felt, ex-vice-presidente do FBI, revelou-se como a pessoa que havia passado as informações para os repórteres americanos. Apesar disso, as investigações jornalísticas, publicadas, à época, pelos meios de comunicação de massa, tiveram relevante repercussão política.

Desses e de outros casos que ilustram a pesquisa, concluímos que é a punição de crimes, o ius puniendi estatal, ou o direito de defesa do acusado, com a possibilidade de trazer elementos de convicção para o juiz, que fundamentam uma necessidade de o jornalista, no processo penal, revelar a origem da informação. 
O constituinte brasileiro, no entanto, fez uma ponderação normativa de valores ao garantir a ampla liberdade de informação, instrumentalizada pelo sigilo da fonte, determinando sua inviolabilidade até mesmo em face dos Poderes do Estado.

Entendemos, também, que a limitação ao segredo, pretendida pela doutrina e jurisprudência dominantes na maioria dos países, não é realmente imprescindível para a busca da verdade no processo penal. O Estado, e não a mídia, deve dispor de todos os meios possíveis para cumprir sua função de investigar e punir. Apesar da precariedade dos instrumentos de busca da prova dos quais se utiliza a atividade jurisdicional, não é admissível que o julgador, para o acertamento dos fatos, coloque-se como refém da identidade da fonte do repórter, cuja informação lhe foi passada para ser divulgada, levada ao conhecimento do público pelos meios de comunicação de massa.

Se a "verdade real" é inalcançável, deve o Poder Judiciário contentar-se com aquela possível, sem aviltar direito constitucional do sigilo que é um limite inerente à prova. Se o Estado não atingir o "fim pretendido" no processo penal, a impunidade do crime, argumento utilizado pela doutrina para justificar a relativização do sigilo, é mal menor na sociedade cuja democracia se estrutura através da informação midiática.

4. A própria Constituição estabelece que o direito ao sigilo da fonte é aquele tutelado em razão da necessidade do trabalho do jornalista. E só nessa condição e para esse fim que a tutela é permitida. Esta cláusula expressa - "quando necessário ao exercício profissonal" - é uma regra estabelecida pelo legislador constituinte, voltada ao princípio da liberdade de imprensa. É um direito passível de regulamentação legal, desde que justificado constitucionalmente. Embora seja norma de eficácia plena, a regulamentação pode garantir o exercício pleno do direito, ao não permitir que fique a critério do julgador, em casos específicos, a decisão sobre o modo de efetivar esse direito, o que acabaria por invadir seu conteúdo, com a consequente violação da Carta Magna.

Em eventual conflito de normas-regras que impõem dever-obrigação de a testemunha "dizer a verdade do que souber ou lhe for perguntado" (art. 203 do CPP) - e garante direito de o jornalista "resguardar o sigilo da fonte, quando necessário ao exercício profissional" (art. 5, IV da CF) - cujas consequências jurídicas vão se apresentar 
contraditórias, deve entender-se que a regra processual não vale para o profissional da mídia e é excetuada por regra com status constitucional de caráter definitivo.

A regra do sigilo jornalístico ou vale exatamente como ordenado pelo legislador constitucional, devendo as circunstâncias fáticas da "necessidade" para o "exercício profissional", estarem preenchidas, ou não se aplica, quando a ela é impossível subsumir.

Deve ser afastada, no caso, a relação de tensão que existe entre o dever de punir do Estado e a liberdade de imprensa, ambos princípios, que são razões para as regras mencionadas (arts. 203 do CPP e $5^{\circ}$, XIV da CF) e, por essas, instrumentalizados. Não se trata, portanto, de analisar qual princípio deve prevalecer, sopesando os valores no caso concreto, mas qual regra deva valer.

A consequência do que se concluiu sobre a estrutura normativa do sigilo da fonte é que o jornalista não pode ser obrigado, por qualquer autoridade estatal, a revelar a identidade da fonte de informação, quando necessário ao trabalho.

5. A única possibilidade de se ter um processo penal justo, com o respeito à norma fundamental do sigilo da fonte, é excluir qualquer valor probatório à informação veiculada sem a identificação da origem. Muitas vezes, a mídia publica informações de dossiês, sem qualquer apuração dos fatos, sob promessa de manutenção do anonimato da fonte, quando não serviriam, sequer, para editar a matéria. Muito menos deve servir para fundamentar a decisão judicial.

Se há uma preocupação da imprensa na identificação da fonte da informação, para que a notícia tenha credibilidade junto ao público, o que fez com que a ética jornalística anglosaxônica exigisse do profissional a confirmação de três fontes diversas para dar fundamento à notícia a qual deveria manter a fonte in off, muito mais deve haver, por parte do julgador, prudência na avaliação do material colhido.

O julgador, no entanto, quando conhece a origem, porque a fonte foi identificada, precisará valorar a prova que, no caso, significa apreciar as circunstâncias dos fatos noticiados, o material que serviu para embasar a notícia. Nem sempre é fácil estabelecer a credibilidade de um notícia ou depoimento, a autenticidade do material jornalístico. Cada 
meio de prova deve ter verificada sua conexão com os fatos, o que consiste, inicialmente, em valorar a credibilidade de cada um deles. Uma vez que a prova foi legitimamente introduzida no processo, o juiz não pode furtar-se a essa percepção, análise, auxiliado pelas partes que podem trazer elementos esclarecedores sobre a qualidade das informações colhidas do jornalista durante a instrução processual. Todavia, se o profissional se recusa a nominar a fonte, a informação que a essa está estreitamente ligada e dependente, não terá valor como prova.

A valoração da prova é direito das partes que decorre do princípio do contraditório. A possibilidade de a informação jornalística, de origem identificada, ser considerada desprovida de valor probatório, vai depender de consideração, de acurada análise judicial que precederá uma decisão motivada, na qual o julgador, pelo método do livre convencimento, poderá concluir que a notícia não é crível, ou que há dúvidas sobre a licitude da colheita das informações, razão pela qual não poderá ser considerada na sentença criminal.

E, finalmente, não poderá ser proferida uma sentença condenatória fundamentada, exclusivamente, em informações jornalísticas cuja origem é anônima. 


\section{REFERÊNCIAS BIBLIOGRÁFICAS}

ACIOLI, Bruno Caiado. O princípio do sigilo da fonte e as suas limitações. Revista Jurídica Consulex, Ano X, n 217, p. 28-29, 2006.

AGUIAR, Asdrúbal. La libertad de expresión, de Cádiz a Chapultepec. Caracas: SIP y Universidad Católica Andrés Bello, 2002.

ALBA, Gerardo Albarrán de. Diferencias em el periodismo de investigación em Estados Unidos y Latinoamérica. In: Web para professionales de la comunicacion Iberoamericanos. n. 32. Año III, vol. 2, junio 2001. Disponível em http://www. saladeprensa.org/art229.htm. Acesso em: 18 de Jul. 2011.

ALBERT P.; TERROU, F. História da imprensa. Tradução Edison Darci Heldt. São Paulo: Martins Fontes, 1990.

ALBRECHT. Hans-Jörg. Vigilância das telecomunicações. Análise teórica e empírica da sua implementação e efeitos. Trad. Inês Fernandes Godinho. In: MONTE, Mário Ferreira; CALHEIROS, Maria Clara; MONTEIRO, Fernando Conde; LOUREIRO, Flávia Noversa (Coords.). Que futuro para o direito processual penal? Simpósio em Homenagem a Jorge de Figueiredo Dias, por ocasião dos 20 anos do Código de Processo Penal Português. Coimbra: Coimbra Ed., 2009, p. 723-743.

AlbuQuerque, Paulo Pinto de. Comentário do Código de Processo Penal à luz da Constituição da República e da Convenção Europeia dos Direitos do Homem. 3 ed. actualizada. Lisboa: Universidade Católica Ed., 2009.

. Os princípios estruturantes do processo penal português - que futuro? MONTE, Mário Ferreira; CALHEIROS, Maria Clara; MONTEIRO, Fernando Conde; LOUREIRO, Flávia Noversa (Coords.). Que futuro para o direito processual penal? Simpósio em Homenagem a Jorge de Figueiredo Dias, por ocasião dos 20 anos do Código de Processo Penal Português. Coimbra: Coimbra Ed., 2009. p. 419-440. 
ALEIXO, Pedro. Segredo profissional. Rio de Janeiro. Revista Forense, Anno XXXIII, fasc. 391, p. 449-455, 1936.

ALEXY, Robert. Teoria dos direitos fundamentais. Tradução de Virgílio Afonso da Silva, 2 ed., São Paulo: Malheiros, 2011.

ALMEIDA, Joaquim Canuto Mendes de. A contrariedade na instrução criminal. São Paulo: Saraiva, 1937.

Princípios fundamentais do processo penal. São Paulo: Ed. Revista dos Tribunais, 1973.

ALMEIDA JR., João Mendes de. Direito judiciário brasileiro. 3 ed., Rio de Janeiro: Freitas Bastos, 1940.

ALMINO, João. O segredo e a informação. Ética e política no espaço público. Ed. Brasiliense, 1986.

AMBOS, Kai. Las prohibicones de utilización de pruebas en el proceso penal alemán. In: Ernst Beling; Óscar Julián Guerrero. Las prohibiciones probatórias. Bogotá: Temis, 2009, p. 59-149.

Implementação do Estatuto de Roma na legislação nacional. In:

MALARINO, Ezequiel. Persecução penal internacional na América Latina e Espanha. Versão brasileira a partir do original em espanhol: Persecución penal internacional em America Latina y España. Tradução e organização: IBCCRIM. São Paulo: IBCCRIM, 2003, p. 27-34.

. El proceso contra Slobodan Milosevic: un balance provisional. Tradução de Rodrigo Aldoney Ramírez. Revista Penal, España, n. 15, p. 3-7, 2005.

. O direito à não-auto-incriminação de testemunhas perante o Tribunal Penal Internacional. Tradução de Karina Pawlowsky e Elouise Mirian Santos. Rio Grande do 
Sul: Pontifícia Universidade Católica. Revista de Estudos Criminais. Ano 2, n. 8, p. 67-85, 2003.

AMODIO, Ennio. Processo penale, diritto europeo e common law: dal rito inquisitório al giusto processo. Milano: Giuffrè, 2003.

Il diritto delle prove penali nel pensiero di Mirjan Damaska. Rivista italiana di diritto e procedura penale. Milano, Anno L, fasc. 1, p. 10-15, gen./mar. 2007.

ANDRADE JARDÍ, Julián. El derecho a la información, los derechos humanos y el periodismo. CARPIZO, Jorge; CARBONELL, Miguel (Coords.). Derecho a la información y derechos humanos. Estudios en homenaje al maestro Mario de La Cueva. México: Instituto de Investigación Jurídicas, 2000, p. 435-445.

ANDRADE, José Carlos Vieira de. Os direitos fundamentais na Constituição portuguesa de 1976. Coimbra: Almedina, 1987.

ANDRADE, Manuel da Costa. Direito Penal Médico. SIDA: Testes arbitrários, confidencialidade e segredo. São Paulo: Revista dos Tribunais e Coimbra: Coimbra Editora (co-edição), 2008.

Sobre as proibições de prova em processo penal. Coimbra: Coimbra Editora, 2006.

. Liberdade de imprensa e inviolabilidade pessoal: uma perspectiva jurídicocriminal. Coimbra: Coimbra Editora, 1996.

“Bruscamente no Verão Passado”, a reforma do Código de Processo Penal.

Observações críticas sobre uma Lei que podia e devia ter sido diferente. Coimbra: Coimbra Ed, 2009.

. Métodos ocultos de investigação. (plädoyer para uma teoria geral)? In:

MONTE, Mário Ferreira; CALHEIROS, Maria Clara; MONTEIRO, Fernando Conde; LOUREIRO, Flávia Noversa (Coords.). Que futuro para o direito processual penal? 
Simpósio em Homenagem a Jorge de Figueiredo Dias, por ocasião dos 20 anos do Código de Processo Penal Português. Coimbra: Coimbra Editora, 2009, p. 525-551.

ANITUA, Gabriel Ignacio. Justicia penal pública. Um estudio a partir del principio de publicidad de los juicios penales. 1 ed. Buenos Aires: Editores Del Puerto, 2003.

ANTUNES, Maria João. O segredo de justiça e o direito de defesa do argüido sujeito a medida de coacção. In: ANDRADE, Manuel da Costa; COSTA, José de Faria; RODRIGUES, Anabela Miranda; ANTUNES, Maria João (Coords.). Liber Discipulorum para Jorge de Figueiredo Dias. Coimbra: Coimbra Ed. 2003. p. 1237-1268.

ARANHA, Adalberto José Q. T. de Camargo. Da prova no processo penal. 7. ed. rev. e atual. São Paulo: Saraiva, 2006.

ARAÚJO, Cláudia. Os crimes dos jornalistas. Uma análise dos processos judiciais contra a imprensa portuguesa. Coimbra: Almedina, 2010.

ARAÚJO, Luiz Alberto David; SERRANO NUNES JÚNIOR, Vidal . Curso de Direito Constitucional. São Paulo: Saraiva, 1998.

ARBEX JR., José. Showrnalismo: a notícia como espetáculo. São Paulo: Casa Amarela, 2001.

ARBOUR, Louise. O equilíbrio justo entre publicidade, direito à vida privada, segredo profissional e busca por justiça. Cidadania e Justiça, Ano 4, n. 9 - 20 semestre, p. 181 186. 2000.

ARRUDA, Eloísa de Sousa. Direitos humanos: o descompasso entre a fundamentação e a efetiva promoção. MALHEIROS, Antonio Carlos; BACARIÇA, Josephina; VALIM, Rafael (Coord.). Direitos humanos: desafios e perspectivas. Belo Horizonte: Fórum, 2011. p. 11-40.

ARRUDA, João. Segredo profissional. Revista dos Tribunaes. São Paulo, V. LXVI, fasc. 342, p. 3-8. maio de 1928 . 
ÁVILA, Fernando Bastos de. Pequena Enciclopédia de Moral e Civismo. 1 ed., Rio de Janeiro: Ministério da Educação e Cultura, 1967.

ÁVILA, Humberto. Teoria dos princípios: da definição à aplicação dos princípios jurídicos. 12 ed. atual. Rio de Janeiro: Malheiros, 2011.

AVOLIO, Luiz Francisco Torquato. Provas ilícitas - interceptações telefônicas, ambientais e gravações clandestinas. 3. ed., São Paulo: Ed. Revista dos Tribunais, 2003.

AZERRAD, Marcos E. Ética y secreto profesional del abogado. Ejercicio y función social de la abogacía. Buenos Aires: Cathedra Jurídica, 2007.

AZZALI, Giampiero. Prove penali e segreti. Milano:Giuffrè, 1967.

BADARÓ, Gustavo Henrique Righi Ivahy. Ônus da prova no processo penal. São Paulo: Ed. Revista dos Tribunais, 2003.

Provas atípicas e provas anômalas: inadmissibilidade da substituição da prova testemunhal pela juntada de declarações escritas de quem poderia ser testemunha. In: YARSHELL, Flávio Luiz; MORAES, Maurício Zanoide de (Orgs.) Estudos em homenagem à professora Ada Pellegrini Grinover. São Paulo: ADJ Editora, 2005, 341352.

BADENI, Gregório. Libertad de prensa. 2 ed., Buenos Aires: Abeledo-Perrot, 1997. . Tratado de libertad de prensa. Buenos Aires: Abeledo-Perrot, 2002.

BALEEIRO, Aliomar. Constituições brasileiras. 1891. Brasília: Senado Federal. 2001. v. II.

; LIMA SOBRINHO, Barbosa. Constituições brasileiras. 1946. Brasília: Senado Federal, 2001. v.5. 
BANDEIRA DE MELLO, Celso Antônio. Elementos de direito administrativo. São Paulo: Ed. Revista dos Tribunais, 1986.

BAPTISTA, Francisco das Neves. O mito da verdade real na dogmática do processo penal. Rio de Janeiro: Renovar, 2001.

BARBALHO U. C., João. Constituição Federal Brazileira. Commentarios. Rio de Janeiro: Litho-Typographia, 1902.

BARBOSA, Rui. A imprensa e o dever da verdade. São Paulo: Papagaio, 2004. Comentarios à Constituição Federal Brasileira. São Paulo: Saraiva, 1934. v. VI.

BARCELLOS, Caco. Jornalismo ativo. In: LOPES, Dirceu Fernandes; PROENÇA, José Luiz. (Orgs.). Jornalismo investigativo. São Paulo: Publisher Brasil, 2003, p. 161-169.

BARRETO, Carlos Roberto. Sigilo da fonte. Disponível em http://jus2.uol.com.br/doutrina/texto.asp?id=7176. Acessado em: 08 mar.2010.

BARROS, Marco Antonio de. Sigilo profissional. Reflexos da violação no âmbito das provas ilícitas. Justitia. São Paulo, v. 175, p.17-33, jul.-set. 1996. A busca da verdade no processo penal. São Paulo: Revista dos Tribunais, 2010.

BARROSO, Luís Roberto. Interpretação e aplicação da Constituição. 2 ed., São Paulo: Saraiva, 1998.

BASTOS, Celso Ribeiro. A liberdade de expressão e comunicação social. Cadernos de Direito Constitucional e Ciência política, São Paulo, ano 5, n. 20, p. 48-52, jul.-set., 1997.

.MARTINS, Ives Gandra. Comentários à Constituição do Brasil: promulgada em 05 de outubro de 1988. São Paulo: Saraiva, 1988. v. 1. 
MARTINS, Ives Gandra da Silva. Comentários à Constituição do Brasil: promulgada em 05 de outubro de 1988. São Paulo:Saraiva, 1989. v. 2.

MEYER-PFLUG, Samantha. Entrevista dos magistrados: sigilo da fonte ou anonimato? Revista da Advocacia Geral da União - Eletrônica. Ano II, n. 10, maio 2011. Disponível em http://www.agu.gov.br. Acesso em: 10 nov. 2011.

BAUDOUIN, Jean-Louis. Secret professionnel et droit au secret dans le droit de la preuve. Paris: L.G.D.J., 1965.

BAZELAIRE, Jean-Paul; CRETIN, Thierry. A Justiça Penal Internacional: sua evolução, seu futuro de Nuremberg a Haia. Tradução Luciana Pinto Venâncio. Barueri: Manole, 2004.

BELING, Ernst Von. Las prohibiciones de prueba como limite a la averiguación de la verdad em el proceso penal. In: ; AMBOS, Kai; GUERRERO, Óscar Julián. Las prohibiciones probatórias. Bogotá, Colombia: Editorial TEMIS S.A., 2009, p. 3-56.

BELLOQUE, Juliana Garcia. Sigilo bancário: análise crítica da LC 105/2001. São Paulo: Revista dos Tribunais, 2003.

BELTRÃO, Luiz; QUIRINO, Newton de Oliveira. Subsídios para uma teoria da comunicação de massa. São Paulo: Summus, 1986.

BEMBA, Joseph. Justice internacionale et liberté d'expression: les médias face aux crimes internationaux. Paris: L’Harmattan, 2008.

BERTOLINO, Pedro J. El juez de garantias em el código procesal penal de la província de Buenos Aires. Buenos Aires: Depalma, 2000. . El debido proceso penal. Buenos Aires: Platense, 1986.

BIANCO, Rosanna. Il diritto del giornalismo. Guida alla professione. Padova: CEDAM, 1997. 
BOBBIO, Norberto. A era dos direitos. Tradução de Carlos Nelson Coutinho. Rio de Janeiro: Campus, 1992.

. A era dos direitos. Tradução de Carlos Nelson Coutinho. Rio de Janeiro: Elsevier, 2004.

Teoria geral da política. Rio de Janeiro: Campus, 2000.

BONAVIDES, Paulo. Curso de Direito Constitucional. 26 ed. atualiz. São Paulo: Malheiros, 2011.

BOURS, Jean Pierre. L'application de la loi fiscale, investigations fiscales et drout au secret. Actualites du Droit: Revue de la Faculté de Droit de Liege, v.3, n.2, p.381-398, avr./juin 1993.

BRAVO, Jorge dos Reis. Inquérito penal e publicidade: novas regras, os mesmos segredos. Revista do Ministério Público, Lisboa, Ano 30, n. 119, p. 5-50, Jul-Set 2009.

BRITO, Luiz Navarro de. A Constituição de 1967. In: CAVALCANTI, Themístocles Brandão; BRITO, Luiz Navarro de; BALEEIRO, Aliomar. Constituições brasileiras. 1967. Brasília: Senado Federal, 2001.

BRITO, Wladimir. Processo penal internacional. In: MONTE, Mário Ferreira; CALHEIROS, Maria Clara; MONTEIRO, Fernando Conde; LOUREIRO, Flávia Noversa (Coords.). Que futuro para o direito processual penal? Simpósio em Homenagem a Jorge de Figueiredo Dias, por ocasião dos 20 anos do Código de Processo Penal Português. Coimbra: Coimbra Ed., 2009, p. 207-246.

BROTÓNS, Iñigo Lazcano. El secreto profesional en el periodismo. Bilbao: Baleuko, 2007.

BUCCI, Eugênio. Sobre ética e imprensa. São Paulo: Companhia das Letras, 2000. 
A imprensa e o dever da liberdade. São Paulo: Contexto, 2009.

BURGH, Hugo de. Um nível elevado de honestidade? In: BURGH, Hugo de. (Coord.). Tradução de Luiza Lusvarghi. Jornalismo Investigativo. Contexto e Prática. São Paulo: Roca, p. 3-28, 2008.

Considerações sobre jornalismo investigativo. In: BURGH, Hugo de (Org.). Jornalismo investigativo: contexto e prática. Trad. Luzia Lusvarghi. São Paulo: Roca, p. 73-97, 2008.

CALAMANDREI, Iolanda. Titolo I. Mezzi di prova. Capo I. Testimonianza. Commento. In: CHIAVARIO, Mario (Coord). Commento al nuovo codice di procedura penale. Torino: UTET, 1990, v. II, p. 423-438.

CAMBI, Eduardo. Verdade processual objetivável e limites da razão jurídica iluminista. Revista de Processo. São Paulo, v.96, p. 232-249, out./dez. 1999.

CANÇADO TRINDADE, Antônio Augusto. A proteção internacional dos direitos humanos: fundamentos jurídicos e instrumentos básicos. São Paulo: Saraiva, 1991.

CANOTILHO, José Joaquim Gomes. Direito Constitucional. 6 ed. Coimbra: Almedina, 1996.

. Estudos sobre Direitos Fundamentais. 2 ed., Coimbra: Coimbra Ed., 2008.

. MOREIRA, Vital. (Organizadores). Constituição da República Portuguesa.

Lei do Tribunal Constitucional. 5 ed. rev. Coimbra: Coimbra Ed., 1998.

. Constituição da República Portuguesa anotada, 3 ed., Lisboa, 1993.

CAPEL, Jose Saez. El derecho a la intimidad y las escuchas telefônicas. Buenos Aires: DIN Ed., 1999. 
CARBONE, Carlos Alberto. Grabaciones, escuchas telefônicas y filmaciones como médios de prueba. Derecho constitucional de utilizar los médios de prueba pertinentes. Santa Fe: Rubinzal-Culzoni, 2005.

CARDOSO, Darlete. A objetividade jornalística é (im)possivel? O discurso e seus efeitos. Disponível em http://www.discurso.ufrgs.br/sead2/doc/discurso/darlete.pdf. Acesso em: 12 de maio 2011.

CARNELUTTI, Francesco. Sistema de derecho procesal civil. Padova: Cedam, 1963, v. 1.

Verdade, dúvida e certeza. Tradução de Eduardo Cambi. GENESIS. Revista de direito processual civil, Curitiba, n. 9, jul./set. 1998, p. 606-609.

CARRILO, Marc. La cláusula de consciencia y el secreto profesional de los periodistas. Madrid: Editorial Civitas, 1992.

.Cláusula de consciência y secreto profesional de los comunicadores. CARPIZO, Jorge; CARBONELL, Miguel (Coords.). Derecho a la información y derechos humanos. Estudios en homenaje al maestro Mario de La Cueva. México: Universidad Nacional Autónoma de México, 2000, p. 401-434.

CARVALHO, Luiz Gustavo Grandinetti Castanho de. Direito de informação e liberdade de expressão. Rio de Janeiro: Renovar, 1999.

Processo penal e constituição: princípios constitucionais do processo penal. 4 ed., rev. e ampl. Rio de Janeiro: Lumen Juris, 2006.

Liberdade de informação e o direito difuso à informação verdadeira. Rio de Janeiro: Renovar, 1994.

CASSESE, Antonio. A influência da CEDH sobre a atividade dos Tribunais Penais Internacionais. In: DELMAS-MARTY, Mireille; CASSESE, Antonio (Coord.). Crimes internacionais e jurisdições internacionais. Trad. Silvio Antunha. Barueri, SP: Manole, 2004, p.171-223. 
CAVALCANTI FILHO, Theóphilo. A liberdade de imprensa na formação constitucional brasileira. Revista dos Tribunais, São Paulo, v. 315, p. 595-606, jan. 1962.

CAZORLA, Alfredo; CERMELE, Leonardo; D’ALESSANDRO, Mauricio; LACALDE, Jimena; PADILLA, Miguel Mendoza. Las fuentes de información em tiempos de guerra. In: Sala de Prensa. Web para professionales de la comunicacion iberoamericanos. Año VI, n. 71, v. 3, p.1-24, Sep. 2004. Disponível em http://www.saladeprensa.org/art564.htm. Acessado em: 06 out. 2011.

CENEVIVA, Walter. Segredos profissionais. São Paulo: Malheiros, 1996.

CHIAVARIO, Mario. O impacto das novas tecnologias: os direitos do indivíduo e o interesse social no processo penal. Tradução Cláudia Cruz Santos. Revista Portuguesa de Ciência Criminal, Coimbra, ano 7, fasc. 3., p. 387-401, jul.-set. 1997.

. Segreto di Stato e giustizia penale. Bologna: Zanichelli, 1978.

. Limites en matière de preuve dans la nouvelle procédure pénale italienne. Revue de science criminelle et de droit penal comparé. Paris, v. 4, p. 30-41, 1992.

. Il nuovo códice di procedura penale visto dall'estero. Milano: Giuffrè, 1991.

.Garanzie individuali ed efficienza del processo. In: Il giusto processo. Milano: Giuffrè, 1998, p. 51-77.

.O processo penal na Itália: um pós-reforma tumultuado. In: DELMASMARTY, Mireille (Org.). Processo penal e direitos do homem: rumo à consciência européia. Tradução Fernando de Freitas Franco. Barueri, SP: Manole, 2004, p. 43-57.

CHOUKE, Fauzi Hassan. Garantias constitucionais na investigação criminal. São Paulo: Revista dos Tribunais, 1995.

CLEINMAN, Betch. Litígios de estrondo entre os $3+1$ Poderes da República. In: Cidadania e Justiça. Ano 3, n. 6, p. 21-29, $1^{\circ}$ semestre de 1999. 
CLEMENTE, Alessandro. MACHADO, André Augusto Mendes. O sigilo e a prova criminal. In: SCARANCE FERNANDES, Antonio et al. (Coord.), Sigilo no processo penal. Eficiência e garantismo. São Paulo: Ed. Revista dos Tribunais, 2008, p. 97-113.

COBO, Dolores Lavalle. Derecho de acceso a La información pública. Buenos Aires: Editorial Astrea, 2009.

COELHO, Sofia Pinto. Jornalistas e Tribunais. Lisboa: Quetzal, 2005.

COLOMER, Juan Luis Gómez; MONTOLIU, Ana Beltrán. La regulación de la prueba em el proceso penal ante la Corte Penal Internacional. In: COLOMER, Juan Luis Gómez; CUSSAC, José Luis González; LLORÉNS, Jorge Cardona (Coords.). La Corte Penal Internacional (Un estudio interdisciplinar). Valencia: Tirant lo Blanch, 2003, p. 325-350.

. La investigación del crimen en el proceso penal ante el Tribunal Penal Internacional. Revista Penal, España, n. 12, p.72-97, Jul. 2003.

; Aspectos generales sobre la prueba y su prática en el proceso ante el Tribunal Penal Internacional. In: AMBOS, K. (Coord.), La nueva Justicia Penal supranacional. Desarrollos Post-Roma. Valencia: Ed. Tirant lo Blanch, 2003, p.102-138.

COMOGLIO, Luigi Paolo. Prove e accertamento dei fatti nel nuovo c.p.p. . Rivista Italiana di Diritto e Procedura Penale, Milano, p. 58-72, jan/mar.1990.

Le prove civili. 3 ed., Torino: UTET, 2010.

COMPARATO, Fábio Konder. Nótula sobre o direito à comunicação social. In: CAVAlCANTI FILHO, José Paulo (Org.). Informação e Poder. Ampla liberdade de informar X Responsabilidade no exercício dessa liberdade. Rio de Janeiro: Record, 1994, p. $67-70$.

. A afirmação histórica dos direitos humanos. 7 edição. São Paulo: Saraiva, 2010 
CONSO, Giovanni. Istituzioni di diritto processuale penale. 2. Ed., Milano: Giuffrè, 1967. . Costituzione e processo penale. Milano: Giuffrè, 1969. Intervento di Giovanni Conso. In: Il giusto processo. Milano: Giuffrè, 1998, p. 1-3.

CORDERO, Franco. Il procedimento probatório. In: . Tre studi sulle prove penali. Milano: Giuffrè, 1963.

CORREIA, Theresa Rachel Couto. Corte Interamericana de Direitos Humanos: repercussão jurídica das opiniões consultivas. Curitiba: Juruá, 2008.

CORVALÁN, Victor. La reserva de la fuente de la información periodistica y la búsqueda de la verdad en el proceso penal. Suplemento de Jurisprudencia Penal, LL, 19 de jul. de 1996.

COSATE, Tatiana Moraes. Liberdade de Informação e sigilo da fonte. Disponível em http://jus2.uol.com.br/doutrina/texto.asp?id=12767, p. 28. Acesso em: 23 set. 2010.

COSTA, Artur Rodrigues da. Segredo de justiça e comunicação social. Revista do Ministério Público, Lisboa, ano 17, n. 68, p. 49-74, out./dez. 1996.

O direito à informação, o dever de informar e os gabinetes de imprensa. Polícia e justiça. Revista do Instituto Superior de Polícia Judiciária e Ciências Criminais. Coimbra, III Série, n. 5, p. 193-214, jan./jun. 2005.

COSTA JÚNIOR, Paulo José. Agressões à intimidade: o episódio Lady Di. São Paulo: Malheiros, 1997.

. Comentários ao Código Penal. São Paulo: Saraiva, 1988.

O direito de estar só: tutela penal da intimidade. 2. ed. rev. e atual. São Paulo: Ed. Revista dos Tribunais, 1995. 
COUCEIRO, João Cláudio. A garantia constitucional do direito ao silêncio. São Paulo: Ed. Revista dos Tribunais, 2004.

COUTINHO, Iluska. O conceito de verdade e sua utilização no jornalismo. Revista Acadêmica do Grupo Comunicacional de São Bernardo, ano 1, n. 1, jan./jun. 2004. Disponível em http://www2.metodista/unesco/GCSB/conceito.pdf. Acesso em 15 de agosto de 2011.

COUTINHO, Jacinto Nelson de Miranda. Efetividade do processo penal e golpe de cena: um problema às reformas processuais. In: WUNDERLICH, Alexandre. Escritos de direito e processo penal em homenagem ao professor Paulo Cláudio Tovo. Rio de Janeiro: Lumen Juris, 2002, p. 143 e ss.

Sistema acusatório: cada parte no lugar constitucionalmente demarcado. In: COUTINHO, Jacinto Nelson de Miranda; CARVALHO, Luis Gustavo Grandinetti Castanho de. (Orgs.). O novo processo penal à luz da Constituição (Análise crítica do Projeto de Lei n. 156/2009, do Senado Federal). Rio de Janeiro: Lumen Juris, 2010, p. 117.

Glosas ao "Verdade, Dúvida e Certeza", de Francesco Carnelutti, para os operadores do Direito. Revista de estudos criminais. Rio Grande do Sul, Ano 4, n. 14. p. 77-94, 2004.

COUTINHO, Léo Meyer. Código de ética médica comentado. São Paulo : Saraiva, 1994.

CRETELLA JR., José. Comentários à Constituição Brasileira de 1988. Rio de Janeiro: Forense Universitária, 1990, v. I.

CUNHA, Paulo José. WikiLeaks. O mundo de pernas para o ar. Disponível em http://observatóriodaimprensa.com.br. Acesso em 26 de dezembro de 2010.

D’AlBORA, Francisco J. Código Procesal Penal de la Nacion. Anotado-ComentadoConcordado. 4 ed., Buenos Aires: Abeledo-Perrot, 1999. 
DALLARI, Dalmo de Abreu. Elementos de teoria geral do estado. 22 ed. São Paulo: Saraiva, 2001.

DANET, M. Jean. (President). Code de Procédure Pénale. Articles modifiés par la loi $\mathrm{n}^{\circ}$ 2004-204 du 9 mars 2004. Le nouveau procès pénal aprés la loi Perben II. Paris: Dalloz, 2004.

DANTAS, Audálio. A busca da informação confiável. In: LOPES, Dirceu Fernandes; PROENÇA, José Luiz. (Orgs.). Jornalismo investigativo. São Paulo: Publisher Brasil, 2003, p. 118-130.

D`AURIA, Aníbal A. Liberdad de expresion y democracia. In: SANDLER, Hector R. (Coord.) El cuarto poder. Expresion, informacion y comunicacion social. Buenos Aires: Ediar, 1999, p.188-205.

DE CUPIS, Adriano. Riservatezza e segreto (diritto a). Novissino digesto italiano. Torino: Torinese, 1969. v. 16, p. 115-124.

DELMANTO, Ricardo. O direito à preservação da fonte. BDJur, Brasília, DF. Disponível em http://bdjur.stj.gov.br/xmlui/handle/2011/9566. Acesso em: 21 fev. 2010.

DELMAS-MARTY, Mireille (Coord). Procedure penali d'Europa. In: CHIAVARIO, Mario (Coord. da edição italiana). Padova: CEDAM, 1998.

DERIEUX, Emmanuel. Droit européen et internacional des médias. Paris: L.G.D.J., 2003. GRANCHET, d’Agnès. Droit des médias. Droit Français, Européen et International. 6.ed. Paris: Lextenso, 2010.

DIAS, Jorge de Figueiredo. Direito processual penal. Coimbra: Coimbra Editora, 1974. v. 1.

DÍAZ, Ramón Soriano. Las libertades públicas: significado, fundamentos y estatuto jurídico. Madrid: Tecnos, 1990. 
DINAMARCO. Cândido Rangel. Instituições de direito processual civil. São Paulo: Malheiros, 2001, v. I.

DINES, Alberto. WikiLeaks, Homens e Máquinas. Tecnologia sozinha não liberta ninguém. Disponível em http://www.observatoriodaimprensa.com.br. Acesso em: 26 dez. 2010 .

DI RONZO, Agnese. Il segreto del giornalista nel processo penale. Il diritto dell'informazione e dell'informatica. Milano, Anno XX, n. 6, dic. 2004, p. 846-854.

DÖHRING, Erich. La prueba. Buenos Aires: Valleta, 2003.

DOSI, Ettore. La tutela del segreto nella prova testimoniale del processo penale. La scuola positiva. Rivista di criminologia e diritto criminale. Milano: Giuffrè, v. 7, p. 433- 455, 1968.

DOTTI, René Ariel. Proteção da vida privada e liberdade de informação. São Paulo: Ed. Revista dos Tribunais, 1980.

DUARTE, José. A Constituição brasileira de 1946: exegese dos textos à luz dos trabalhos da Assembléia Constituinte. Rio de Janeiro, 1947. 2 v.

DUHALDE, Eduardo Luis; ALÉN, Luis Hipólito. Teoria Jurídico-Política de la Comunicación. Buenos Aires: EUDEBA, 2007.

DUMAS, Roland. Le droit de l'information. Paris: Presses universitaire de France, 1981.

DWORKIN, Ronald. O direito da liberdade. São Paulo: Martins Fontes, 2006.

ECHANDÍA, Hernando Devis. Teoria general de la prueba judicial. Bogotá - Colombia: Editorial Temis S.A., 2006.

ECO, Umberto. Sobre a imprensa. In: Cidadania e Justiça. Ano 3, n. 6, p. 6-20, $1^{\circ}$ semestre 1999. 
EIRAS, Agostinho. Segredo de justiça e controlo de dados pessoais informatizados. Coimbra: Coimbra Ed., 1992.

EKMEKDJIAN, Miguel Angel. Tratado de Derecho Constitucional. Buenos Aires: Depalma, 1997. T. IV.

.Derecho a la información. Reforma constitucional y libertad de expresión. Nuevos aspectos. 2 ed., Buenos Aires: Depalma, 1996.

ESPÍNOLA, Eduardo. Constituição dos Estados Unidos do Brasil (18 de setembro de 1946). São Paulo: Freitas Bastos, 1952. v. 1.

ESPÍNOLA FILHO, Eduardo. Código de Processo Penal brasileiro anotado. 4. ed., Rio de Janeiro: Borsoi, 1954, v. 1.

Código de processo penal brasileiro anotado. 5 ed. Rio de Janeiro: Editora Rio, 1976. v. 3.

FADALTI, Luigi. La testimonianza nel giudizio penale. Milano: Giuffrè, 2008.

FALCÃO, Joaquim. WikiLeaks. EUA não têm bandeira em guerra contra o WikiLeaks. Reproduzido da Folha de São Paulo, 19/12/2010. Disponível em http://www.observatoriodaimprensa.com.br. Acesso em: 26 dez. 2010.

FARALLI, Carla. Bioetica e confessione religiose: uma prospettiva laica. In: CAMASSA, Erminia; CASONATO, Carlo. Bioetica e confessioni religiose. Atti del Convegno tenuto presso la Facoltà di Giurisprudenza di Trento, Il 12 maggio 2006. Trento: Lavis, 2008, p. 105-121.

FARBER, Daniel A. The first amendment. 2. ed. New York: The Foundation Press, 2003.

FARIA, José Eduardo. Poder e legitimidade. São Paulo: Perspectiva, 1978. 
FAUSTO NETO, Antonio. Vozes do impeachment. In: MATOS, Heloíza (Org.). Mídia, eleições e democracia. São Paulo: Página Aberta, 1994, p. 159-191.

FERNANDEZ ENTRALGO, Jesús. In: La clausula de conciencia y el secreto profesional de los periodistas. Madrid: Centro de Estudios Constitucionales, 1994, p.57-58.

FERNANDEZ-MIRANDA, Alfonso. El secreto profesional de los informadores. Madrid:Tecnos, 1990.

FERRAJOLI, Luigi. Prólogo da obra de GUZMÁN, Nicolás. La verdade en el proceso penal: una contribuición a la epistemologia jurídica. Buenos Aires: Editores del Puerto, 2006.

Derecho y razón. Teoria del garantismo penal. Tradução de Perfecto Andrés Ibáñez et al. Madrid: Trotta, 1997.

FERRAZ JR., Tércio Sampaio. Sigilo de dados: o direito à privacidade e os limites à função fiscalizadora do Estado. Revista da Faculdade de Direito da USP, São Paulo, v.88, p. 439-459, 1993.

- Liberdade de opinião, liberdade de informação: mídia e privacidade. Cadernos de Direito Constitucional e Ciência Política, São Paulo, ano 06, n. 23, p. 24-29, abr./ jun. 1998.

FERREIRA, Aluízio. Direito à informação, direito à comunicação: direitos fundamentais na Constituição brasileira. São Paulo: Celso Bastos Editor: Instituto Brasileiro de Direito Constitucional, 1997.

FERREIRA FILHO, Manoel Gonçalves. Princípios fundamentais de direito constitucional. 2 ed. São Paulo: Saraiva, 2010.

. Comentários à Constituição brasileira de 1988. 2 ed. São Paulo: Saraiva, 1997. v. 1. 
FERREIRA, Waldemar Martins. História do direito constitucional brasileiro. Brasília: Senado Federal, 2003.

FIDALGO, Joaquim. A questão das fontes nos códigos deontológicos dos jornalistas. Revista Comunicação e Sociedade, n. 2, vol. 14 (1-2), 2000, p. 319-337. Disponível em http://repositorium.\&dum.uminho.pt/bitstuam/1822/5511/1/CS_vol2_p.339-349.pdf. Acesso em: 15 maio 2010.

FIGUEIREDO DIAS, Jorge de. O processo penal português: problemas e perspectivas. In: MONTE, Mário Ferreira; CALHEIROS, Maria Clara; MONTEIRO, Fernando Conde; LOUREIRO, Flávia Noversa (Coords.). Que futuro para o direito processual penal? Simpósio em Homenagem a Jorge de Figueiredo Dias, por ocasião dos 20 anos do Código de Processo Penal Português. Coimbra: Coimbra Editora, 2009, pp. 805-819.

Direito penal. parte geral. questões fundamentais - A doutrina geral do crime. Coimbra: Coimbra Ed., 2004, t. I.

FINOCCHIARO, Alfio e Mario. Costituzione della Repubblica Italiana e leggi sulla Corte Costituzionale. 2 ed.,Rimini: Maggioli, 1995.

FINOCCHIARO, Francesco. Diritto ecclesiastico. 10ª ed., Bologna: Zanichelli, 2009.

FISS, Owen. La ironia de la libertad de expresión. Traducción. Víctor Ferreres Comella e Jorge F. Malem Seña. Barcelona:GEDISA, 1999.

FLORIAN, Eugenio. Delle prove penali. Milano: Istituto Editoriale Cisalpino, 1961. Elementos de derecho procesal penal. Traducción de L. Prieto Castro. Barcelona: Bosch, 1934.

FLORIOT, Renet. Le secret professionnel. Paris: Flammarion, 1973.

FORTES, Leandro. Jornalismo investigativo. São Paulo: Contexto, 2010. 
FOSCHINI, Gaetano. Sistema del diritto processuale penale. 2 ed., Milano: Giuffrè, 1965.

FRAGOSO, Heleno Cláudio. A nova Lei de Segurança Nacional. Disponível em http://www.fragoso.com.br/eng/arq...pdf/heleno_artigos/arquivo32.pdf. Acesso em: 31 ago. 2011.

Lições de direito penal - Parte especial. 4. Ed. Rio de janeiro: Forense, 1984.

v. 2.

FRANCO, Benedito Luiz. Proteção constitucional do sigilo da fonte na comunicação jornalística. São Paulo: Celso Bastos, Instituto Brasileiro de Direito Constitucional, 1999.

FRANCO, João Melo. Conceitos e princípios jurídicos: na doutrina e jurisprudência. Coimbra: Almedina, 1983.

FREITAS, Helena de Sousa. Sigilo profissional em risco. Análise dos casos de Manso Preto e de outros jornalistas no banco dos réus. Coimbra: Minerva Coimbra, 2006.

FROTA, Hidemberg Alves da. Os limites ao sigilo das fontes jornalísticas. Revista Nacional de Direito e Jurisprudência, v.6, n.77, p.25-31, maio 2006.

A quebra do sigilo das fontes jornalísticas pelo Poder Judiciário. In: Revista Jurídica do Ministério Público Catarinense, Santa Catarina, n. 8, v. 4, p. 137-146, jan./abr. 2006.

GALLI, Maria Beatriz; DULITZKY, Ariel E. A Comissão Interamericana de Direitos Humanos e o seu papel central no sistema interamericano de proteção dos direitos humanos. In: Luiz Flávio Gomes e Flávia Piovesan (coord.), O sistema interamericano de proteção dos direitos humanos e o direito brasileiro, São Paulo: Ed. Revista dos Tribunais, 2000.

GARCIA, José Cuenca. La revelación del secreto sumarial. Revista de derecho y proceso Penal, Navarra, n. 15, p. 71-99, 2006. 
GARCÍA, Luis M. La protección de la identidad de las fuentes periodísticas a la luz de los instrumentos internacionales de derechos humanos y de los estándares de sus órganos de aplicación. In: Anuario de Derecho Constitucional Latinoamericano. p. 635-676, 2004. Disponível em www.juridicas.unam.mx. Acesso em 12 de julho de 2011.

GARIBALDI, Gustavo E.L. Las modernas tecnologías de control y de investigación del delito. Su incidencia en el derecho penal y los principios constitucionales. Buenos Aires: Ad-Hoc, 2010.

GASPAR, António Henriques. As exigencias da investigação no proceso penal durante a fase de instrução. In: MONTE, Mário Ferreira; CALHEIROS, Maria Clara; MONTEIRO, Fernando Conde; LOUREIRO, Flávia Noversa (Coord.).Que futuro para o direito procesual penal? Simpósio em homenagem a Jorge de Figueiredo Dias, por ocasião de 20 anos do código de proceso penal português. Coimbra: Coimbra Editora, 2009, p. 87-101.

GASPARINI, Alessandro. Il prosecutor e le scansioni dell azione penale. In: MUSSO, Rosanna Gambini. (Coord.). Il processo penale statunitense: soggetti ed atti. 3 ed., Torino: G. Giappichelli Editore. 2009, p. 76-78.

GELLI, María Angélica. Libertad de expresion em Argentina: los desafios de la nueva comunicacion. In: SANDLER, Hector R. (Coord.). El cuarto poder: expresion, informacion y comunicacion social. Buenos Aires: Ediar, 1999, p. 207-230.

GOODWIN, H. Eugene. Procura-se ética no jornalismo. Tradução de Álvaro de Sá. Rio de Janeiro: Editorial Nórdica, 1993.

GOMES, Luiz Flávio. $A$ questão da obrigatoriedade dos tratados e convenções no Brasil: particular enfoque da Convenção Americana sobre Direitos Humanos. Revista dos Tribunais. São Paulo, v. 710, p. 21-31, dez. 1994.

GONÇAlVES, Manuel Lopes Maia. Código de Processo Penal: anotado. 10 ed. rev. atualiz. Coimbra: Almedina, 1999. 
GONZAGA, João Bernardino. Violação de segredo profissional. São Paulo: Max Limonad, 1976.

.A inquisição em seu mundo. 8 ed., São Paulo: Saraiva, 1994.

GONZÁLEZ, Santiago Sánchez. Los médios de comunicación y los sistemas democráticos. Madrid: Marcial Pons, 1996.

GORPHE, François. Apreciación judicial de las pruebas. Traducción de Luis AlcaláZamora y Castillo. Buenos Aires: Hammurabi, 2007.

GORLERO, Maurizio Pedrazza. Giornalismo e costituzione. Padova: CEDAM, 1988.

GÖSSEL, Karl Heinz. La busqueda de la verdad em el proceso penal. Aspectos jurídicoconstitucionales y político-criminales. Tradução de Miguel Polaino Navarrete. In: Cuadernos de Política Criminal, Madrid, n. 45, p 673-693, 1991.

GOUVEIA, Jorge Bacelar. Segredo de Estado. Disponível em www.estig.ipebeja.pt/ ac_direito/BGSefredo.pdf. Acesso em: 05 maio 2010.

GRASSI, Carmelo. Sigillo (Origine e sviluppo storico del). In:Enciclopedia Giuridica Italiana. Milano: Società Editrice Libraria, 1925. v. XV, parte II, sez. II, p. 661-688.

GRAU, Eros Roberto. Ensaio e discurso sobre a interpretação/aplicação do direito. 5 ed., rev. atual. São Paulo: Malheiros, 2009.

GRECO FILHO, Vicente. Interceptação telefônica: considerações sobre a Lei n. 9.296, de 24 de julho de 1996. São Paulo: Saraiva, 2008.

GREVI, Vittorio. Nemo tenetur se detegere. Interrogatorio dell'imputato e diritto al silenzio nel processo penale italiano. Milano: Giuffrè, 1972.

Alla ricerca di um processo penale "giusto": itinerari e prospettive. Milano:

Giuffrè, 2000. 
O segredo como limite à prova no processo penal italiano. Tradução de Roberto Orlando Pucci. Ciência Penal, São Paulo, Ano II, n. 4, p. 3-23, 1975. Prove. In: ; CONSO, Giovanni. Compendio di procedura penale. 2 ed. Milano: CEDAM, 2003, p. 283- 361.

GRINOVER, Ada Pellegrini. Liberdades públicas e processo penal. São Paulo: Ed. Revista dos Tribunais, 2 ed., 1982.

A eficácia dos atos processuais à luz da Constituição Federal. Revista da Procuradoria Geral do Estado de São Paulo, São Paulo, p. 34, jun. de 1992.

.O regime brasileiro das interceptações telefônicas. Revista de Direito Administrativo, Rio de Janeiro, v. 207, p. 21-38, jan./mar. 1997.

. MAGALHÃES GOMES FILHO, Antonio; SCARANCE FERNANDES, Antonio . As nulidades no processo penal. 12 ed., rev. atualiz. São Paulo: Ed. Revista dos Tribunais, 2011.

. Lineamenti generali del nuovo processo penale in America Latina e punti di convergenza com il modello italiano. In: CHIAVARIO, Mario (Cord.). Il nuovo codice di procedura penale visto dall 'estero. Milano: Giuffrè, 1991, p. 137-167

GROSSO, Carlo Frederico. Sviluppi recenti del diritto penale della informazione a mezzo stampa. Boletim da Faculdade de Direito. Coimbra, v. LXV, p. 291-304, 1989.

GUEDJ, M. Alexis. Liberté et responsabilités em droit européen et international. In:BEINGNIER, Bernard; LAMY, Bertrand de; DREYER, Emmanuel. (Directeurs) Traité de Droit de la presse et des médias. Paris: LexisNexis, 2009.

GUZMÁN, Nicolás. La verdad en el proceso penal: una contribuición a la epistemologia jurídica.Tradução de Pablo Eiroa. Buenos Aires: Editores del Puerto, 2006. 
HABERMAS, Jürgen. $O$ valor $d a$ notícia. Disponível em http://www1.folha.uol.com.br/fsp/mais/fs2705200707.htm - Acesso em 27 de dezembro de 2010.

Verdade e justificação: ensaios filosóficos. Tradução de Milton Camargo Mota. São Paulo: Loyola, 2004.

HALLÉ, Mathilde. Discours politique et Cour européenne dês droits de l'homme. Fondements et limites de La liberte d'expression politique dans la jurisprudence de la Cour de Strasbourg. Bruxelles: Bruylant, 2009.

HOUAISS, Antonio; VILLAR, Mauro Salles; FRANCO, Francisco Manoel de Mello. Dicionário Houaiss da Língua Portuguesa. Rio de Janeiro: Objetiva, 2001.

HUNGRIA HOFFBAUER, Nelson. A violação do segredo profissional. Revista dos Tribunais. São Paulo, Anno XXV, v. XCIX, fasc. 428, p. 297-305, jan. 1936.

HUNGRIA, Nelson. A disciplina jurídica da liberdade de pensamento e informação. Revista dos Tribunais. Edição histórica. São Paulo, p. 457-466, dez. 2009.

ILLUMINATI, Giulio. La diciplina processuale delle intercettazioni. Milano:Giuffrè, 1983.

KARAN, Maria Lúcia. Sobre o ônus da prova na ação penal condenatória. Revista Brasileira de Ciências Criminais, São Paulo, v. 35, p. 55/73, jul./set. 2001.

KEHDI, André Pires de Andrade. O sigilo da ação penal - Aspectos gerais. In: SCARANCE FERNANDES, Antonio et al. (Coord.), Sigilo no processo penal: eficiência e garantismo. São Paulo: Ed. Revista dos Tribunais, 2008, p. 57-95.

. MACHADO, André Augusto Mendes. Sigilo das comunicações e de dados. In: SCARANCE FERNANDES, Antonio et al. (Coord.). Sigilo no processo penal. Eficiência e garantismo. São Paulo: Ed. Revista dos Tribunais, 2008, p.239-266. 
KENWORTHY, Bill. Branzburg v. Hayes, reporters`privilege \& circuit courts. Disponível em http://www.firstamedmentcenter.org/analysis.aspx?id=15525. Acesso em 20 de julho de 2011.

KERCHOVE, Michel van de. La preuve em matière pénale dans la jurisprudence de la Cour et de la Comission Européennes dês Droits de 1'Homme. Revue de Science Criminelle et de Droit Penal Comparé. Paris: Sirey, p. 1-14, 1992.

KIERAN, Matthew. Estrutura ética e regulatória do jornalismo investigativo. BURGH, Hugo de. (Org.) Jornalismo investigativo: contexto e prática. Tradução de Luiza Lusvarghi. São Paulo: Roca, 2008, p. 173-194.

KOLLER, James R. Confidential information under the Code of Professional Responsibility. Dick L. Rev., v. 79, 1974-1975.

KOSTORIS, Sérgio. Il "segreto" come oggetto della tutela penale. Padova: CEDAM, 1964.

KOVACH, Bill; ROSENSTIEL, Tom. Os elementos do jornalismo: o que os jornalistas devem saber e o público deve exigir. Tradução de Wladir Dupont. 2 ed. São Paulo: Geração Editorial, 2004.

LACAVA, Thaís Aroca Datcho. O sigilo nas Comissões Parlamentares de Inquérito e as garantias individuais. In: SCARANCE FERNANDES, Antonio et al. (Coord.), Sigilo no processo penal: eficiência e garantismo. São Paulo: Ed. Revista dos Tribunais, 2008, p.115-137.

SOBRINHO, Mário Sérgio. O sigilo profissional e a produção de prova. In: SCARANCE FERNANDES, Antonio et al. (Coord.),Sigilo no processo penal: eficiência e garantismo. São Paulo: Ed. Revista dos Tribunais, 2008, p.171-202.

LAFER, Celso. Diplomacia, sigilo, vazamentos. O Estado de São Paulo - Opinião - 19 de dezembro de 2010. 
LAGE, Nilson. . A reportagem: teoria e técnica de entrevista e pesquisa jornalística. Rio de Janeiro: Renovar, 2001.

LAMBERT, Pierre. Secret professionnel. Bruxelles: Brylant, 2005.

LATTANZI, Giorgio. Codice di procedura penale: annotato con la giurisprudenza. 6. ed. Milano: Giuffrè, 2010.

LAZCANO BROTÓNS, Iñigo. El secreto professional en el periodismo: estúdios sobre um derecho fundamental. Bilbao: Lete, 2007.

LAZZARINI, Álvaro. Ética e sigilo profissionais. Revista de direito administrativo. São Paulo, n.204, p.53-64, abr./jun. 1996.

LEAL, Hamilton. História das instituições políticas do Brasil. Brasília: Ministério da Justiça, 1994.

LECLERC, Henri. Les limites de la liberté de la preuve: aspects actuels em France. Revue de science criminelle et de droit pénal comparé. Paris, p. 15-29, 1992.

LEITE, André Lamas. Segredo de justiça interno, inquérito, argüido e seus direitos de defesa. Revista Portuguesa de Ciência Criminal, ano 16, n. 4, p. 539-573, out./dez. 2006.

LEITE FILHO, Solidônio. Comentários à lei de Imprensa. Rio de janeiro: J. Leite \& Cia, 1925.

LIEBMAN, Enrico Tullio. Manuale di diritto processuale civile. 4. ed., Milano: Giuffrè, 1984. v. II.

LIMA, Hugo de Meira. O segredo profissional e suas limitações. Revista Forense, Rio de Janeiro, v.49, n.144, p.554-556, nov./dez. 1952.

LIMA SOBRINHO, Barbosa. Direito de informação. Revista de Informação Legislativa, Brasília, ano 17, n. 67, p. 147-198, jul/set. 1980. 
LOPES, Dirceu Fernandes. Caminhos do jornalismo investigativo em busca da verdade oculta. In: LOPES, Dirceu Fernandes; PROENÇA, José Luiz. (Orgs.) Jornalismo Investigativo. São Paulo: Publisher Brasil, 2003, p. 9-27.

LOPES Junior, Aury. Sistemas de investigação preliminar no processo penal. Rio de Janeiro: Lúmen Júris, 2001.

; DI GESU, Cristina Carla. Falsas memórias e prova testemunhal no processo penal: em busca da redução de danos. Revista de Estudos Criminais. Rio Grande do Sul, Ano VII, n. 25, p. 59-69, 2007.

LORETI, Damián: El derecho a la información. Buenos Aires: Paidós, 1995.

LUCA, Javier Augusto de. El secreto de las fuentes periodísticas en el processo penal. Buenos Aires: Ad-Hoc, 1999.

LUCAS, Javier de. Secretos de Estado. Revista del Instituto Bartolomé de las Casas. Derechos y libertades. Ano IV, p. 35-61, jan.1999.

LÚCIO, Laborinho. Processo penal e consciência coletiva. In: MONTE, Mário Ferreira; CALHEIROS, Maria Clara; MONTEIRO, Fernando Conde; LOUREIRO, Flávia Noversa (Coords.). Que futuro para o direito processual penal? Simpósio em Homenagem a Jorge de Figueiredo Dias, por ocasião dos 20 anos do Código de Processo Penal Português. pp. 135-152. Coimbra: Coimbra Ed., 2009, p. 135-152.

LUZÓN PEÑA, Diego-Manuel. Tratamiento del secreto profesional en el derecho español. Barcelona:PPU, 1991.

MACHADO, Jónatas E. M. Liberdade de expressão: dimensõs constitucionais da esfera pública no sistema social. Coimbra: Coimbra Ed., 2002.

MACHADO, Paulo Afonso Leme. Direito à informação e meio ambiente. São Paulo: Malheiros, 2006. 
MADLENER, Kurt. El ejercicio legítimo del deber de información del periodista, como causa de justificación en el proceso penal por injurias y difamación. In: Justicia Penal y Libertad de Prensa. Ilanud, San José, oct., 1993, t.1. Disponível em http//www.ilanud.or.cr/centro-de-documentacion/biblioteca-digital/176-justicia-penal-ylibertad-de-prensa.html. Acesso em: 20 jul. 2011.

MADOUX, Martine Ract. Criminalitè, procés pénal et moyens de communication. In: SANTOS, Marino Barbero; DÍAZ-SANTOS, Maria Rosario Diego (Coord). Criminalidad, medios de comunicación y proceso penal. Salamanca: Ediciones Universidad de Salamanca, 2000.

MAGALHÃES GOMES FILHO, Antonio. Direito à prova no processo penal. São Paulo: Revista dos Tribunais, 1997.

. Presunção de inocência e prisão cautelar. São Paulo: Saraiva, 1991.

. Provas ilícitas e recurso extraordinário. In: PENTEADO, Jaques Camargo (Coord.). Justiça Penal. Críticas e sugestões: provas ilícitas e reforma pontual. São Paulo: Ed. Revista dos Tribunais, 1997, p. 32-47.

Provas. Lei 11.690, de 09.06.2008. In: MOURA, Maria Thereza Rocha de Assis. (Coord). As reformas no processo penal. As novas Leis de 2008 e os Projetos de Reforma. São Paulo: Ed. Revista dos Tribunais, 2008, p. 246-297.

A motivação das decisões penais. São Paulo: Ed. Revista dos Tribunais, 2001.

GRINOVER, Ada Pellegrini; SCARANCE FERNANDES, Antonio. As nulidades no processo penal. 9. ed. São Paulo: Ed. Revista dos Tribunais, 2006.

Notas sobre a terminologia da prova (reflexos no processo penal brasileiro). In: YARSHELL, Flávio Luiz; MORAES, Maurício Zanoide de (Orgs.). Estudos em homenagem à professora Ada Pellegrini Grinover. São Paulo: DJP Ed., 2005, p. 303-318. 
BADARÓ, Gustavo Henrique Righi Ivahy. Prova e sucedâneos de prova no processo penal brasileiro. Revista Brasileira de Ciências Criminais. São Paulo, n. 65, p. 75-208, mar./abr. 2007.

MAGNOLI, Demétrio. WikiLeaks: herói sem nenhum caráter. Reproduzido de O Estado de S. Paulo, 23/12/2010; intertítulos do OI. Disponível em http://www.observatóriodaimprensa.com.br . Acesso em 26 dez. 2010.

MALATESTA, Nicola Framarino Dei. A lógica das provas em matéria criminal. Tradução: Paulo Capitanio. Brasil: Bookseller, 1996. v.I.

MANCERON, Gilles. Milosevic doit être jugé a La Haye. Entretien avec Miroslav Filipovic, journaliste serbe. Revue de la Ligue des droits de l'homme. Hommes \& Libertés. n. 112, p. 18-19, jan./fév. 2001.

MARCONDES FILHO, Ciro. Comunicação e jornalismo: a saga dos cães perdidos. São Paulo: Haker, 2000.

MARQUES, José Frederico. Elementos de direito processual penal. Rio de Janeiro: Forense, 1965. v. II.

MARQUES, Luiz Guilherme. A justiça da França: um modelo em questão. Leme, SP: Editora de Direito, 2001.

MARTÍNEZ-VILLALBA, Ruan Carlos Riofrío. El derecho de los secretos: postulado de uma teoria general, p. 3. Disponível em www.ibero-americano.org. Acesso em 12 de ago. de 2011.

MARTINS, Ives Gandra da Silva. Sigilo profissional: prerrogativa inviolável. Consulex: revista jurídica, v.8, n. 187 , p. 28-29, out.2004.

MARTINS, João Zenha. O segredo jornalístico, a protecção das fontes de informação e o incidente de quebra de escusa de depoimento. Revista do Ministério Público. Lisboa, Ano 27, n. 106, p.83-137, abr/jun 2006. 
MARZADURI, Enrico. Diritto alla prova testimoniale e modalità di escussione del testimone. .Verso uno statuto del testimone nel processo penale. Milano:

Giuffrè, 2005, pp. 15-35.

MASSA, Michele. Contributo all'analisi del giudizio penale di primo grado.Milano: Giuffrè, 1964.

MAXIMILIANO, Carlos. Comentários à Constituição Brasileira de 1891. Brasília: Senado Federal, 2005.

MEIREIS, Manuel Augusto Alves. O regime das provas obtidas pelo agente provocador em processo penal. Coimbra: Almedina, 1999.

MELO, José Marques de. Teoria da comunicação: paradigmas latino-americanos. Petrópolis: Vozes, 1998.

. A opinião no jornalismo brasileiro. Petrópolis: Vozes, 1985.

MENDES, Gilmar Ferreira. Direitos fundamentais e controle de constitucionalidade: estudos de direito constituonal. 2 ed., rev. atual. São Paulo: Celso Bastos Editor, 2009.

Os direitos fundamentais e seus múltiplos significados na ordem constitucional. Revista Eletrônica de Direito do Estado, n. 23, jul./set. 2010. Disponível em http://www.direitodoestado.com.br. Acesso em: 20 jul.2011.

MIRANDA, Jorge. Manual de Direito Constitucional: Direitos fundamentais. 4 ed., Coimbra: Coimbra Ed., 2008. t. IV.

MITTEMAIER, Karl Joseph Anton. Tratado de la prueba em matéria criminal. Buenos Aires: Hammurabi, 2006.

MOLINARI, Fancesca Maria. Il segreto investigativo. Milano:Giuffrè, 2003.

MORAES, Alexandre de. Direito constitucional. 19 ed., São Paulo: Atlas, 2006. 
. Constituição do Brasil interpretada e legislação constitucional. 6 ed., São Paulo: Atlas, 2006.

MORAES, Maurício Zanoide de. Presunção de inocência e processo penal brasileiro: análise de sua estrutura normativa para a elaboração legislativa e para a decisão judicial. Rio de Janeiro: Lumen Juris, 2010.

MORANGE, Jean. La liberte d'expression. Paris: Presses Universiatires de France, 1993.

MORÃO, Helena. Responsabilidade jurídico-penal dos jornalistas por violação do segredo de Estado: contributo para o estudo do tema segurança e comunicação social. In: GOUVEIA, Jorge Bacelar; PEREIRA, Rui. (Coords.). Estudos de direito e segurança. Lisboa: Almedina, 2007, p. 157-170.

MOREIRA, José Carlos Barbosa. O novo processo civil brasileiro. 6 ed. Rio de Janeiro: Forense, 1984.

MORELLO, Michele. Il nuovo processo penale: parte generale. Padova: CEDAM, 2000.

MORENO, Javier. WikiLeaks. O que os governos ocultam. Reproduzido do El País, 1912 2010; título original "Lo que de verdad ocultan los Gobiernos", texto em espanhol. Disponível em http://observatoriodaimprensa.com.br. Acesso em: 26 dez. 2010.

MOURA, Maria Tereza Rocha de Assis. Justa causa para a ação penal: doutrina e jurisprudência. São Paulo: Ed. Revista dos Tribunais, 2001.

MUÑOZ CONDE, Francisco. Búsqueda de la verdad em el proceso penal. Buenos Aires: Hammurabi, 2000.

MUSCO, Enzo. Justicia penal y libertad de prensa: informe sobre Italia. In: Justicia Penal y Libertad de Prensa, Ilanud, San José, t.1, p. 587-623, oct. 1993. Disponível em http//www.ilanud.or.cr/centro-de-documentacion/biblioteca-digital/176-justicia-penal-ylibertad-de-prensa.html. Acesso em 17 ago. 2011. 
Justicia Penal y Libertad de prensa. Entre verdad y secreto. In: Justicia Penal

y Libertad de Prensa, Ilanud, San José, tomo 1, p. 257-290, oct. 1993. http//www.ilanud.or.cr/centro-de-documentacion/biblioteca-digital/176-justicia-penal-ylibertad-de-prensa.html.

NARDI, Sandro de. La liberta di espressione dei magistrati. Napoli: Jovene Editore, 2008.

NESPRAL, Bernardo. Manual de periodismo judicial. Periodismo y derecho. Buenos Aires: García Alonso, 2005

NEUMANN, Ulfried. La pretensión de verdad en el derecho y tres ensayos sobre Radbruch. Traducción Mauricio Hernández. Colombia: Universidad Externado de Colombia, 2006.

NOBRE, Freitas. Comentários à Lei de Imprensa. 4 ed., São Paulo: Saraiva,1989. Imprensa e liberdade: os princípios constitucionais e a nova legislação. São Paulo: Summus, 1988.

NOGUEIRA, Carlos Frederico Coelho. Comentários ao código de processo penal - e, a partir dele, aos dispositivos correlatos de toda a legislação especial inclusive o Código de Processo Penal Militar. Bauru-SP: Edipro, 2002.

NOGUEIRA, Octaciano. Constituições brasileiras. 1824. Brasília: Senado Federal, biênio 2003/2004. v.I.

NOVAIS, Jorge Reis. Prefácio do livro "Sigilo profissional em risco". In: FREITAS, Helena de Sousa. Sigilo profissional em risco. Análise dos casos de Manso Preto e outros jornalistas no banco dos réus. Coimbra: Minerva, 2006, pp. 11-15.

NOVOA MONTREAL, Eduardo. Derecho a la vida privada y libertad de información: un conflito de derechos. México: Siglo Veintiuno, 1979. 
NUCCI, Guilherme de Souza. Código penal comentado. 5 ed., São Paulo: Ed. Revista dos Tribunais, 2005.

NUNES JÚNIOR, Vidal Serrano. Direito e jornalismo. São Paulo: Verbatim, 2011.

NUVOLONE, Pietro. Il diritto penale della stampa. Padova: Cedam, 1971.

Il segreto giornalistico. In: Segreti e prova penale. Atti del Convegno. Milano: Giuffrè, 1979, p. 100-105.

OLIVEIRA, João Gualberto. Liberdade de Imprensa no Brasil e na Suécia. São Paulo: Sociedade Brasileira de Expansão Comercial, 1956.

OLVERA, Salvador Ochoa. Las fuentes del periodista: secreto profesional?. México: Montealto, 2005.

OSSOLA, Frederico; VALLESPINOS, Gustavo. La obligación de informar. Córdoba: Advocatus, 2001.

OTERO GONZÁLEZ, María del Pilar. El secreto de las fuentes del periodista. Justicia y secreto profesional. Madrid: Universidad Carlos III, 2001. Disponível em www.vlex.com/doctrina/Justicia_secreto_profesional/2300-407,030.html. Acesso em 14 de nov. 2011.

PAGALLO, Ugo. La tutela della privacy negli Stati Uniti d'America e in Europa: modelli giuridici a confronto. Milano: Giuffrè, 2008.

PAGLIARINI, Alexandre Coutinho; AGOSTINI, Leonardo Cesar de. A relação entre regime democrático e direito à informação. In: Direitos Fundamentais e Justiça, Porto Alegre, RS, ano 3, n. 8, p. 73-80, jul-set. 2009.

PATRÍCIO, Rui; GERALDO, Tiago. O crime de violação de segredo de justiça e a reforma penal de 2007 (algumas considerações e um caso- tipo de jornalistas).Revista do Ministério Público. Lisboa, Ano 30, n. 119, p. 51-68, jul./set 2009. 
PENA, Felipe. Teoria do jornalismo. 2 ed. São Paulo: Contexto, 2006.

PENTEADO, Jacques de Camargo. Duplo grau de jurisdição no processo penal: garantismo e efetividade. São Paulo: Ed. Revista dos Tribunais, 2006.

; A natureza das normas sobre as provas criminais. Revista dos Tribunais, São Paulo, Ano 93, v. 819, p. 397-413, 2004.

PEREIRA, Eliomar da Silva. O problema da verdade na investigação criminal. Revista Brasileira de Ciências Criminais. ano 19, v. 91, p. 91-135, jul./ago. 2011.

PEREIRA, Merval. WikiLeaks: a busca da verdade. Reproduzido de O Globo, 19/12/2010; intertítulos do OI. Disponível em http://www.observatoriodaimprensa.com.br. Acesso em: 26 dez. 2010.

PEREIRA, Raimundo. Investigar faz parte do jornalismo. In: LOPES, Dirceu Fernandes; PROENÇA, José Luiz. (Orgs.) Jornalismo Investigativo. São Paulo: Publisher Brasil, 2003, p. 27-41.

PÉREZ, Marvin Carvajal. O Tribunal Constitucional da Costa rica. Revista da Faculdade de Direito da USP, São Paulo, v. 91, p. 201-219, 1996.

PIMENTA BUENO, José Antonio. Direito público brasileiro e análise da Constituição do império. Rio de Janeiro: Ministério da Justiça, 1958.

PINHO, Rodrigo César Rebello. O respeito ao sigilo da fonte jornalística. Consulex, revista jurídica, v.10, n.217, p.31-32, jan.2006.

PINHO, Maria Cecília Labate Maiolini Rebello. O sigilo da fonte como garantia da liberdade de informação jornalística. Dissertação de Mestrado apresentada na Faculdade de Direito da Universidade de São Paulo, 2007.

PINTO FILHO, Francisco Bilac M. O segredo de Estado e as limitações ao habeas data. Revista dos Tribunais. Fasc. Civ., Ano 91, v. 805, p. 34-59, nov. 2002. 
PINTO, Ricardo Leite. Direito de informação e segredo de justiça no direito português. Revista da ordem dos Advogados, Lisboa, n. 51, p. 509-523, jul. 1991.

. Liberdade de imprensa e vida privada. Revista da Ordem dos Advogados, Lisboa, ano 54, n. 27, p. 27-147, 1994

PIOVESAN, Flávia. Direitos humanos e o direito constitucional internacional. São Paulo: Max Limonad, 1996.

. Direitos humanos e justiça internacional. São Paulo:Saraiva, 2007.

PISA, Paolo. Il segreto do Stato. Milano:Giuffrè, 1977.

PISANI, Mario. La tutela penale delle prove formate nel processo. Milano: Giuffrè, 1959.

. Testimonianza e segreti. In: La testimonianza nel processo penale. Atti del Convegno. Milano: Giuffrè, 1974, p. 63-103.

PISAPIA, Gian Domenico. Il segreto istruttorio nel processo penale. Milano: Giuffrè, 1960.

PITOMBO, Cleonice A. Valentim Bastos Pitombo. Processo penal: prova e verdade. Tese de doutorado apresentada na Faculdade de Direito da Universidade de São Paulo. São Paulo, 2003.

Da busca e apreensão no processo penal. 2 ed. rev. aum. atual. São Paulo: Ed. Revista dos Tribunais, 2005.

POLETTI, Ronaldo. Constituições brasileiras. 1934. Brasília: Senado Federal, 2001. v. III.

PONTES DE MIRANDA, Francisco Cavalcanti. Comentários à Constituição da República dos Estados Unidos do Brasil. Rio de Janeiro: Guanabara, 1934. 
Democracia, liberdade, igualdade: os três caminhos. 2. ed. São Paulo: Saraiva, 1979.

. Comentários à Constituição de 1946. (arts. 129-144). Rio de Janeiro: Boffoni, 1947. v. III.

PORTO, Walter Costa. Constituições brasileiras. 1937. Brasília: Senado Federal, 2001. v. IV.

PRADEL, Jean. Procédure pénale. 10 ed., Paris: Cujas, 2000.

PRADERA, Javier. La extraña pareja: notas para un debate sobre la clausula de conciencia y el secreto profesional. In: La clausula de conciencia y el secreto profesional de los periodistas. Madrid: Centro de Estudios Constitucionales, 1994, pp. 21-39.

PRADO, Geraldo. Limites às interceptações telefônicas e a jurisprudência do Superior Tribunal de Justiça. Rio de Janeiro: Lumen Juris, 2005.

PRAVIA, Alverto. Las fuerzas de seguridad em el procedimiento penal. Normativa, análisis, jurisprudência. Córdoba: Editorial Mediterránea, 2008.

QUIROGA LAVIÊ, Humberto. La protección de la intimidad y la regulación del secreto. In: CARPIZO, Jorge; CARBONELL, Miguel (Coords.). Derecho a la información y derechos humanos: estudios en homenaje al maestro Mario de La Cueva. México: Instituto de Investigación Jurídicas, 2000, p. 503-522.

RAMONET, Inacio. A tirania da comunicação. Tradução Lúcia Mathilde Endlich Orth. Petrópolis, Rio de Janeiro: Vozes, 1999.

RAMOS, André de Carvalho. Direitos humanos em juízo: comentários aos casos contenciosos e consultivos da Corte Interamericana de Direitos Humanos. São Paulo: Editora Max Limonad, 2001. 
RÁO, Vicente. O direito e a vida dos direitos. São Paulo: Ed. Resenha Universitária, 1976. v.I, t. I.

REALE, Miguel. Filosofia do direito. 10 ed, rev. e atual. São Paulo: Saraiva, 1983.

REGO, Hermenegildo de Souza. Dever de sigilo e escusa de depor. Revista de Processo, São Paulo, ano IX , n.33, p. 201-222, jan./mar. 1984.

RICUPERO, Rubens. Pior que o WikiLeaks. Folha de S. Paulo, 26 de dez. 2010, p. A11.

RIVERA, Julio César. La libertad de expresión y las expresiones de Odio. Buenos Aires: Abeledo Perrot, 2009.

ROBERT, Jacques. Le secret défense. Secret et démocratie. Paris, 1997.

ROCHA, Manuel António Lopes. A liberdade de expressão como direito do homem. Engrenagens de poder: Justiça e comunicação social. Sub Judice: Justiça e Sociedade, Lisboa, jun./dez., n. 15/16, p. 2-22, 1999.

RODAS, João Grandino. A Corte Interamericana dos Direitos Humanos. Revista do Curso de Direito da Universidade Federal de Uberlândia. Uberlândia, v. 10, n. (1 e 2), 1981.

RODRÍGUEZ BAHAMONDE, Rosa. El secreto del sumario y la libertad de información en el proceso penal. Madrid: Dykinson, 1999.

RODRIGUES, Benjamim Silva. Das escutas telefônicas: a monitorização dos fluxos informacionais e comunicacionais. 2 ed., Coimbra: Coimbra Ed., 2008. t. I.

RODRIGUES, J. N. Cunha. Justiça e comunicação social: mediação e interacção. Revista Portuguesa de Ciência Criminal. Coimbra, ano 7, fasc. 4, p. 531-576, out/dez. 1997.

RODRÍGUEZ, Esteban. Justicia mediática: la administración de justicia em los médios masivos de comunicación. Las formas del espetáculo. Buenos Aires: Ad-Hoc, 2000. 
RODRÍGUEZ, Víctor Gabriel. A inviolabilidade do sigilo da fonte. Disponível em http://observatoriodaimprensa.com.br/artigos.asp?cod=343IPB004. Acesso em 17 maio 2010.

ROIG, Rafael de Asís. Secreto profesional e informacion. Derechos y Libertades. Revista del Instituto Bartolome de las Casas, Madrid, Año I, n. 2, p. 153-176. oct./mar. 1994.

ROMERO COLOMA, Aurelia Maria. Derecho a la información y libertad de expresión: especial consideración ao processo penal. Barcelona: Bosch, 1984.

; Derecho y deber de reserva y libertad de informacion en el ordenamiento jurídico penal italiano. Actualidad Penal. Alcobendas, Madrid, n. 41, p. 2145-2154, 13 nov. 1988.

ROSA, Inocêncio Borges da. Processo penal brasileiro. Porto Alegre: Globo, 1942, v. 1.

ROXIN, Claus. Derecho Procesal Penal. Tradução de Gabriela E. Córdoba y Daniel R. Pastor. 25 ed. Buenos Aires: Editores del Puerto, 2003.

RUEFF, Maria do Céu. O segredo médico como garantia de não-discriminação. Estudo de Caso: HIV/SIDA. Coimbra: Coimbra Ed., 2009.

SÁEZ, Maria Tereza Mercado. El infoshow com cámara oculta: investigación periodística $o$ espetáculo? Sala de Prensa. Web para professionales de la comunicacion iberoamericanos, n. 84, ano VII, v. 3, oct. 2005. Disponível em http://www.saladeprensa.org/art640.htm. Acesso em: 18 de ago. de 2011.

SAGÜÉS, Néstor Pedro. Censura judicial previa a la prensa. Posición de la Corte Interamericana de Derechos Humanos. Biblioteca Jurídica Virtual del Instituto de Investigações Jurídicas de la UNAM. Disponível em www.juridicas.unam.mx. Acesso em: 22 de fev. de 2011. 
SANCHES, Inês Raposo. Os direitos fundamentais dos jornalistas no acesso às fontes de informação, ao sigilo profissional e à protecção da independência. Dimensões concretizadoras do direito à liberdade de imprensa. Relatório da parte escolar do curso de aperfeiçoamento conducente ao Mestrado em Ciências Jurídico-Políticas 2002/2003/. Apresentado na Faculdade de Direito da Universidade de Lisboa. Setembro de 2003.

SÁNCHEZ, Miguel Revenga. Trazando los limites de lo tolerable: libertad de expresión y defensa del ethos democrático em la jurisprudência constitucional española. In: PIZZORUSSO, A.; ROMBOLI R.; RUGGERI A.; SAITTA A.; SILVESTRI G. (cords.). Libertà di manifestazione del pensiero e giurisprudenza costituzionale. Milano: Giuffrè, 2005, p. 213-244.

SANTIAGO, Rodrigo. Do crime de violação de segredo profissional no Código Penal de 1982. Coimbra: Almedina, 1992.

Jornalistas e "segredo profissional". Sub Judice. Justiça e sociedade. ns 15/16, p. 147-152, jun./dez. 1999.

SANTOS, Boaventura de Sousa. Wikiliquidação do império? Reproduzido da Agência Carta maior, 12 dez. 2010. Disponível em http://www.observatoriodaimprensa.com.br. Acesso em: 26 de out. 2010.

SANTOS, Moacyr Amaral. Comentários ao Código de Processo Civil. 3 ed., atual., Rio de Janeiro: Forense, 1982, vol. IV.

SARLET, Ingo Wolfgang. A eficácia dos direitos fundamentais. Uma teoria geral dos direitos fundamentais na perspectiva constitucional. 10 ed. rev. atual. ampl. Porto Alegre: Livraria do Advogado, 2009.

SCANDONE, Giuseppe. Il segreto di stato come species del genus segreto. Definizione. In: MOSCA, Carlo; SCANDONE, Giuseppe; GAMBACURTA, Stefano; VALENTINO, Marco. (Coords.) In: I servizi di informazione e il segreto di stato. (Legge 3 agosto 2007, n. 124). Milano: Giuffrè, 2008, p. 443-480. 
SCARANCE FERNANDES, Antonio. A Lei de interceptação telefônica. In: PENTEADO, Jaques de Camargo. (Coord.). Justiça Penal: críticas e sugestões : provas ilícitas e reforma pontual. São Paulo: Ed. Revista dos Tribunais, 1997, n. 4, p. 48-70.

. Reflexões sobre as noções de eficiência e de garantismo no processo penal. In: SCARANCE FERNANDES, Antonio; ALMEIDA, José Raul Gavião de; MORAES, Maurício Zanoide de. Sigilo no processo penal: eficiência e garantismo. São Paulo: Ed. Revista dos Tribunais, 2008. p. 9-28.

O sigilo financeiro e a prova criminal. In: COSTA, José Faria; SILVA, Marco Antonio Marques da. Direito penal especial, processo penal e direitos fundamentais: visão luso-brasileira. São Paulo: Quartier Latin, 2006.

Processo penal constitucional. In: SCARANCE FERNANDES, Antonio. Processo penal constitucional. 6 ed. rev. atual .ampl. São Paulo: Ed. Revista dos Tribunais, 2010.

SEGRELLES ARENAZA, Iñigo de. El secreto de Estado ilegal: aspectos básicos. Cuadernos de política criminal. Madrid, n. 62, 1997, p.415-433.

SEQUEIRA, Cleofe Monteiro de. Jornalismo investigativo. O fato por trás da notícia. São Paulo: Summus, 2005.

SÉRGIO SOBRINHO, Mario. Segredo de Estado e prova ilícita. Justitia, São Paulo, v. 62 n. 189/192, p. $149-174$, jan./dez. 2000.

; LACAVA, Thaís Aroca Datcho. O sigilo profissional e a produção da prova. In: SCARANCE FERNANDES, Antonio; ALMEIDA, José Raul Gavião de; MORAES, Maurício Zanoide de.(Coord.) Sigilo no processo penal: Eficiência e garantismo. São Paulo: Ed. Revista dos Tribunais, 2008.

SERRANO, Nicolas Gonzalez-Cuellar. Proporcionalidad y derechos fundamentales en el proceso penal. Madrid: Colex, 1990. 
SHINA, Fernando E. La libertad de expresión y otros derechos personalísimos. Buenos Aires: Editorial Universidad, 2009.

SILVA, De Plácido e. Vocabulário jurídico. Rio de Janeiro: Forense, 1993, v. 4.

SILVA, Deonísio da. WikiLeaks: um mundo sem confidências. Disponível em http://www.observatóriodaimprensa . Acesso em: 26 de dez. de 2010.

SILVA, Germano Marques da. Curso de Processo Penal, 2 ed., Lisboa:VERBO, 2000, v.I. . Curso de processo penal. 2 ed., rev. atual., Lisboa:VERBO, 1999, v. II.

A publicidade do processo penal e o segredo de justiça. Um novo paradigma? Revista Portuguesa de Ciência Criminal, Coimbra, ano 18, ns. 2 e 3, p. 257-276, abr./ set. 2008 .

SILVA, Virgílio Afonso. Direitos fundamentais: conteúdo essencial, restrições e eficácia. 2 ed., São Paulo: Malheiros, 2010.

Princípios e regras: mitos e equívocos acerca de uma distinção. Revista Latino-Americana de Estudos Constitucionais , n.1, p 607-630, 2003.

SILVEIRA, Renato de Mello Jorge. Da verdade dada à verdade buscada. Boletim IBCCrim, São Paulo, n. 101, abr. 2001.

SIRACUSANO, Delfino. Prova: III nel nuovo códice di procedura penale. Enciclopedia Giuridica, Roma, 1992, t. I.

SOARES, Guido Fernando Silva. Common law: introdução ao direito dos EUA. São Paulo: Ed. Revista dos Tribunais, 1999.

SORIA, Carlos. El labirinto informativo: uma salida ética. Pamplona: Ediciones Universidad de Navarra, 1997. 
SORTINO, Carlos A. El periodismo de investigación, a juicio. Los imperdonables. Web para professionales de la comunicacion Iberoamericanos. Año II, v. 2, n. 11, set. 1999. Disponível em http://www. saladeprensa.org/art.htm. Acesso em: 18 jul. 2011.

SOUSA, Américo de. A retórica da verdade jornalística. Disponível em http://www.bocc.ubi.pt/pag/sousa-americo-retorica-verdade-jornalistica-pdf. Acesso em: 18 ago. 2011.

SOUZA, Diego Fajardo Maranha Leão de. Sigilo profissional e prova penal. Revista Brasileira de Ciências Criminais, São Paulo, n. 73, p.107-155, ago. 2008.

SPANGHER, Giorgio. Titolo I. Mezzi di prova. Capo I. Testimonianza. Commento. In: CHIAVARIO, Mario (Coord). Commento al nuovo codice di procedura penale. Torino: UTET, 1990, v. II, p. 455-477.

SUCAR, Germán; RODRÍGUEZ, Jorge L.; IGLESIAS, Agustín. Violacion de secretos y obligación de denunciar: un dilema fictício. Um comentário crítico al fallo "Zambrana Daza”. Cuadernos de doctrina y jurisprudencia penal. Buenos Aires, n.8, p. 190-296, s/d.

SUIAMA, Sergio Gardenghi. O direito fundamental à comunicação no STF. In: AMARAL JÚNIOR, Alberto; JUBILUT, Liliana Lyra (Orgs.). O STF e o direito internacional dos direitos humanos. São Paulo: Quartier Latin, 2009.

TAMBOSI, Orlando. Teoria da Comunicação. Elementos (e confusões) do jornalismo. Disponível em http://observatoriodaimprensa.com.br/artigos/al190820036p.htm. Acesso em: 27 de dez. de 2010.

TARUFFO, Michele. La prova dei fatti giuridici. Milano: Giuffrè, 1992. La prueba. Traducción de Laura Manríquez y Jordi Ferrer Beltrán.. Madrid: Marcial Pons, 2008.

.Il processo civile adversary nell'esperienza americana. Padova: CEDAM, 1979. 
Conocimiento científico y critérios de la prueba judicial. Tradução de Lucas Correa Montoya. In: TARUFFO, Michelle; CARVAJAL, Diana Ramírez. Conocimiento, prueba, pretensión y oralidad. Lima, Peru: ARA Editores, 2009, pp. 11-30.

TAVARES, André Ramos. Curso de direito constitucional. 5 ed. rev. atual. São Paulo: Saraiva, 2007.

TEIXEIRA, Mônica. Investigação é fundamento do jornalismo. In: LOPES, Dirceu Fernandes; PROENÇA, José Luiz. (Orgs.). Jornalismo investigativo. São Paulo: Publisher Brasil, 2003, pp. 169-179.

THOMPSON, John B. A mídia e a modernidade: uma teoria social da mídia. Tradução Wagner de Oliveira Brandão. Petrópolis: Vozes, 1998.

TIRANTI, V. E. L'opinione pubblica nei suoi rapporti com la prova. Pisa: Enrico Spoerri, 1903.

TONINI, Paolo. A prova no processo penal italiano. Tradução Alexandra Martins e Daniela Mróz. São Paulo: Ed. Revista dos Tribunais, 2002.

TORNAGHI, Hélio Bastos. Instituições de processo penal. Rio de Janeiro: Forense, 1959. v. 1 . . Instituições de direito processual penal. São Paulo: Saraiva, 1978, v.4.

TORRES, Mário Araújo. Algumas considerações sobre a liberdade de informação e segredo profissional dos jornalistas. Revista do Ministério Público. Lisboa, Ano 3, n. 12, p. 143-162, 1982.

TOURINHO FILHO, Fernando da Costa. Processo penal. 25 ed., São Paulo: Saraiva, 2003. v.3. 
TROCKER, Nicolo. Processo civile e costituzione (problemi di diritto tedesco e italiano). Milano: Giuffrè, 1974.

TUCCI, Rogério Lauria. Curso de direito processual civil. São Paulo: Saraiva, 1989. V.2.

UBERTIS, Giulio. Corte Europea dei Diritti Dell 'Uomo e 'processo equo'. In: Processo penale e giustizia europea. Omaggio a Giovanni Conso. Atti Del Convegno, Torino 26-27 setembre 2008 (2010). Milano: Giuffrè, 2010, p. 31-47.

. La prova penale. Profili giuridici ed epistemologici. Torino:UTET, 1999.

Il processo penale.Bologna: Il Mulino, 2008.

VALIANTE, Mario. Il nuovo processo penale: principi fondamentali. Milano: Giuffrè, 1975.

VALLE FILHO, Oswaldo Trigueiro do. A ilicitude da prova: teoria do testemunho de ouvir dizer. São Paulo: Revista dos Tribunais, 2004.

VALLEJO, Enrique Jean. Libertad de expresión y delitos contra el honor. Madrid:Colex, 1992 ,

VALLEJO, Manuel Jaén. Principios constitucionales y derecho penal moderno. Buenos Aires: Ad-Hoc, 1999.

.Derechos procesales fundamentales: su proyección en la fase de instrucción, em el juicio oral y em el sistema de recursos. In: ALFARO, Luis Miguel Reyna; AROCENA, Gustavo A., SALGADO, David Cienfuegos (Coords.). La prueba, reforma del proceso penal y derechos fundamentales. Lima, Peru: Jurista Editores, 2007. p. 29-56.

VASCONCELOS, Frederico. Anatomia da reportagem: como investigar empresas, governos e tribunais. São Paulo: Publifolha, 2008. 
VENTURA, Adrian. Libertad de expresion y garantias. Buenos Aires: La Ley, 2009, p. 29.

VIEIRA, Ana Lúcia Menezes. Processo penal e mídia. São Paulo: Ed. Revista dos Tribunais, 2003.

VIEIRA, Jair Lot (supervisão editorial). Código de ética médica, código de processo éticoprofissional para os Conselhos de Medicina. Bauru: Edipro, 1993.

VIEIRA, Luís Guilherme. O fenômeno opressivo da mídia: uma abordagem acerca das provas ilícitas. Discursos sediciosos: crime, direito e sociedade. Rio de Janeiro: Freitas Bastos, 1998.

WAREMBOURG-AUQUE, Francoise. Réflexions sur le secret professionnel. Revue de science criminelle et de droit pénal comparé. Paris, n. 2, p. 237-256, avr./jun. 1978.

ILSON, Alex Mu oz. Caso "La Última Tentación de Cristo": reflexiones en torno al primer fallo sobre libertad de expresión en el sistema americano de derechos humanos. In:FRANCHINI, María Belém y otros (Coord). Libertad de expresión y democracia desde una perspectiva latinoamericana. Buenos Aires: Fabian J. di Placido, 2002, p. 97-42.

ZACCARIA, Roberto. Diritto dell'informazione e della comunicazione. 4 ed., Milano: CEDAM, 2003.

ZENO-ZENCOVICH, Vicenzo; CLEMENTE, Michele; LODATO, Maria Gabriella. La responsabilità professionale del giornalista e dell 'editore. Padova: CEDAM, 1995.

ZILLI, Marcos Alexandre Coelho. A prova ilícita e o Tribunal Penal Internacional: regras de admissibilidade. Tese apresentada ao curso de Pós-Graduação da Faculdade de Direito da Universidade de São Paulo, área de concentração em Direito Processual, como requisito parcial à obtenção do título de Doutor em Direito. São Paulo: FADUSP, 2006. 
Bem-aventurados os sedentos de justiça... In: PIOVESAN, Flávia; SOARES, Inês Virgínia Prado (Coords). Direito ao desenvolvimento. Belo Horizonte: Editora Fórum, 2010. p. 591-611.

ZULIANI, Ênio Santurelli. In: GOMES JR, Luiz Manoel. (Coord.) Comentários à lei de Imprensa: Lei 5.250/1967- artigo por artigo. São Paulo: Ed. Revista dos Tribunais, 2007. p. $37-198$.

Outras fontes:

ORGANIZAÇÃO DOS ESTADOS AMERICANOS. Principais instrumentos do sistema interamericano de promoção e proteção dos direitos humanos. A Comissão Interamericana de Direitos Humanos: como é e como funciona. Edição resumida do manual de normas vigentes. Washington, EUA, 1994.

Manual da Redação da Folha de São Paulo, São Paulo: Publifolha. 2001.

DICIONÁRIO HOUAISS da língua portuguesa. 1 ed., Rio de Janeiro: Objetiva, 2001. 
